\title{
GEOHYDROLOGY AND SIMULATION OF GROUND- WATER FLOW NEAR LOS ALAMOS, NORTH-CENTRAL NEW MEXICO
}

By Peter F. Frenzel

\section{U.S. GEOLOGICAL SURVEY \\ Water-Resources Investigations Report 95-4091}

Prepared in cooperation with

LOS ALAMOS NATIONAL LABORATORY

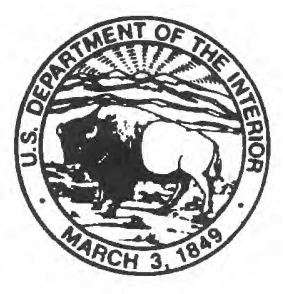

Albuquerque, New Mexico

1995 


\section{U.S. DEPARTMENT OF THE INTERIOR \\ BRUCE BABBITT, Secretary \\ U.S. GEOLOGICAL SURVEY \\ Gordon P. Eaton, Director}

For additional information

write to:

District Chief

U.S. Geological Survey

Water Resources Division

4501 Indian School Rd. NE, Suite 200

Albuquerque, New Mexico 87110
Copies of this report can

be purchased from:

U.S. Geological Survey Earth Science Information Center Open-File Reports Section Box 25286, MS 517

Denver Federal Center

Denver, Colorado 80225 


\section{CONTENTS}

Page

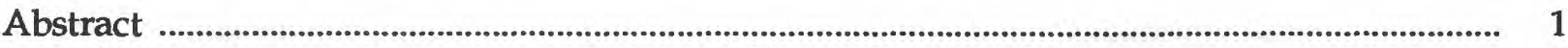

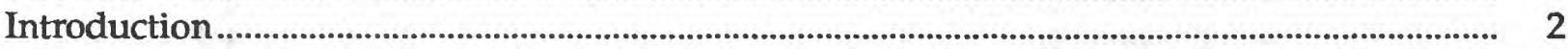

Purpose and scope ...................................................................................................... 2

Location of the study area .................................................................................................. 2

Well-numbering system .................................................................................................. 5

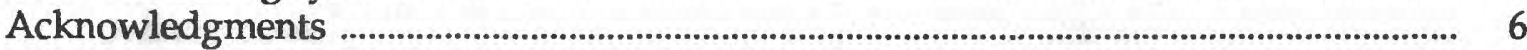

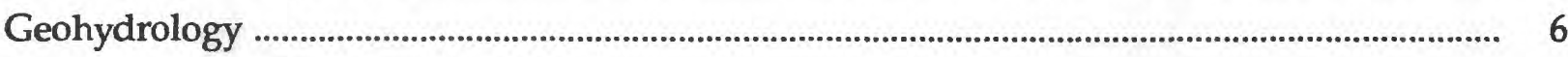

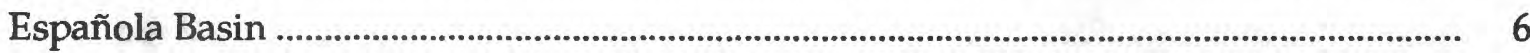

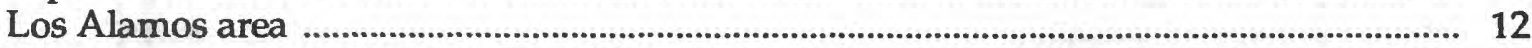

Ground-water flow, recharge, and discharge ............................................................ 18

Ground-water withdrawals and changes in recharge ................................................. 20

Simulation of ground-water flow ....................................................................................... 24

Description of the model and modifications to the McAda-Wasiolek model ................... 24

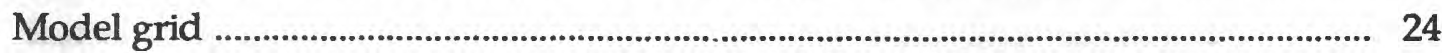

Hydraulic conductivity, transmissivity, and leakance ........................................ 25

Specific yield and storage coefficients .................................................................. 32

Initial condition and time periods .......................................................................... 32

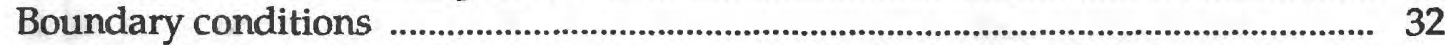

Constant ground-water recharge and discharge ............................................ 33

Variable ground-water withdrawals and recharge......................................... 35

Other modifications .......................................................................................................... 36

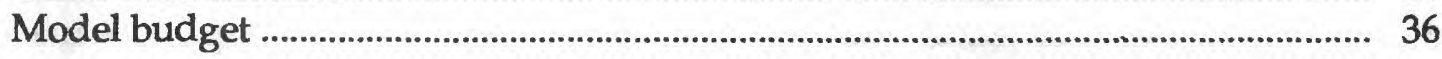

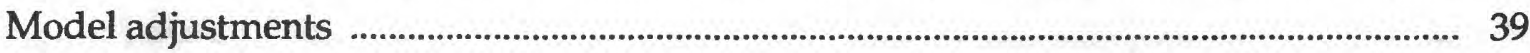

System properties used for comparison ................................................................ 39

System properties adjusted ............................................................................... 51

Recharge .................................................................................... 51

Hydraulic conductivity near Los Alamos .................................................. 52

Specific yield and storage ........................................................................ 52

Simulated response to projected withdrawals ........................................................... 54

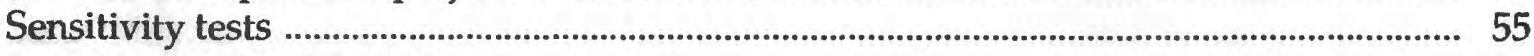

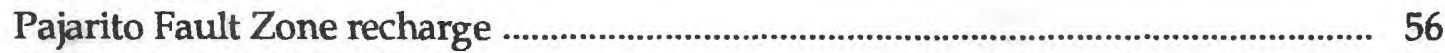

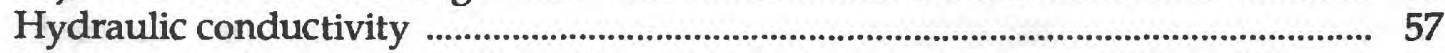

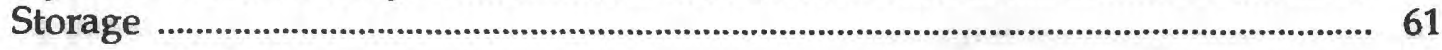

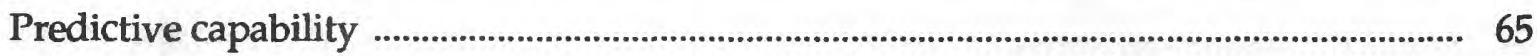

Data needs for an improved understanding of the flow system ............................................ 68

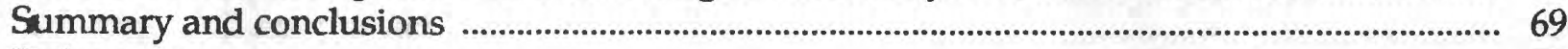

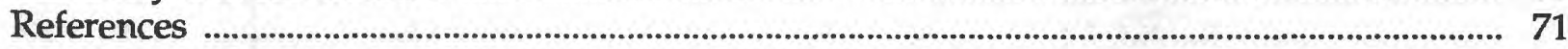

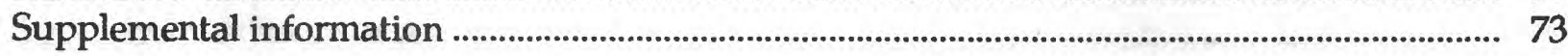




\section{FIGURES}

Page

Figure 1. Map showing location of the study area in north-central New Mexico

2. Map showing location of major well fields and selected streamflow-gaging stations in the study area, north-central New Mexico

3. Diagram showing system of numbering wells based on the Federal land-survey system

4-6. Maps showing:

4. Major tectonic features of north-central New Mexico

5. General geology of the study area, north-central New Mexico........................... 8

6. Predevelopment potentiometric surface in the upper part of the Tesuque aquifer system, north-central New Mexico

7. Fence diagram of the Pajarito Plateau, north-central New Mexico.

8. Graphs showing ground-water withdrawals from well fields and estimated withdrawals from individual wells in the Española Basin, north-central New Mexico

9. Map showing horizontal model grid and extent of layers

10. Diagrammatic section along model row 9 showing model layers and subsurface geology

11-17. Maps showing:

11. Hydraulic-conductivity values for layers 1-3.

12. Hydraulic-conductivity values for layers 4 and 5 30

13. Boundary conditions represented in layer 1 of the model. 31

14. Distribution of areal recharge in the model, in inches per year 34

15. Model-derived potentiometric surface for layer 1 and measured hydraulic heads for 1977.

16. Model-derived potentiometric surface for layer 1 and measured hydraulic heads for 1993.

17. Location of wells having hydrographs

18-22. Hydrographs for wells in the:

18. Los Alamos well field, north-central New Mexico. 44

19. Guaje well field, north-central New Mexico 45

20. Pajarito Mesa well field, north-central New Mexico. 46

21. Buckman well field, north-central New Mexico. 48

22. Santa Fe area, north-central New Mexico. 49

23. Map showing steady-state potentiometric surface for layer 1 53 


\section{FIGURES--Concluded}

Figures 24-31. Hydrographs showing effect of:

24. Moving specified-flow recharge of the Pajarito Fault Zone from layer 1 to layer 4

25. Moving specified-flow recharge of the Pajarito Fault Zone from layer 1 to layer 4 , using larger flow values.

26. Using smaller horizontal hydraulic-conductivity values in the northwestern part of the model.

27. Using larger horizontal hydraulic-conductivity values in the northwestern part of the model

28. Using smaller vertical hydraulic-conductivity values.................................... 63

29. Using larger vertical hydraulic-conductivity values...................................... 64

30. Using smaller storage values ...................................................................... 66

31. Using larger storage values......................................................................... 67

\section{TABLES}

Table 1. Estimated horizontal hydraulic conductivity in Los Alamos National Laboratory production and selected test wells.................................................................................... 14

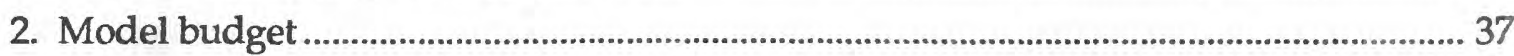

3. Model budget items that change with time...................................................................... 38

4. Average of differences between measured and model-derived hydraulic heads for the standard and each sensitivity test, in feet .......................................................... 56

5. Constant-flow-boundary recharge rates, in cubic feet per second................................... 74

6. Specified discharge from Los Alamos wells, in cubic feet per second............................. 76

7. Specified discharge from Guaje wells, in cubic feet per second ........................................ 78

8. Specified discharge from Pajarito Mesa and Otowi wells, in cubic feet per second..... 80

9. Specified discharge from Buckman wells, in cubic feet per second.................................. 81

10. Specified discharge from Santa Fe wells, in cubic feet per second.................................... 82

11. Percentage of public-supply well pumpage assigned to each model layer................... 84

12. Specified discharge from domestic and industrial wells, in cubic feet per second....... 85

13. Difference between measured and model-derived hydraulic heads, in feet.................. 86 


\section{CONVERSION FACTORS AND VERTICAL DATUM}

$\begin{array}{lc}\text { Multiply } & \text { By } \\ \text { inch } & 25.4 \\ \text { foot } & 0.3048 \\ \text { mile } & 1.609 \\ \text { acre } & 4,047 \\ \text { square mile } & 2.590 \\ \text { cubic foot } & 0.02832 \\ & 7.48 \\ \text { acre-foot } & 0.001233 \\ & 43,560 \\ \text { per foot } & 3.281 \\ \text { foot per day } & 0.3048 \\ \text { foot per mile } & 0.1894 \\ \text { foot squared per day } & 0.09290 \\ \text { cubic foot per second } & 0.02832 \\ & 448.8 \\ \text { acre-foot per year } & 0.0013803 \\ & 0.6184 \\ \text { gallon per minute } & 0.06309 \\ & 0.002228 \\ \text { billion gallons per year } & 4.2361\end{array}$

To obtain

millimeter

meter

kilometer

square meter

square kilometer

cubic meter

gallons

cubic hectometer

cubic feet

per meter

meter per day

meter per kilometer

meter squared per day

cubic meter per second

gallons per minute

cubic foot per second

gallon per minute

liter per second

cubic foot per second

cubic feet per second

Temperature in degrees Celsius $\left({ }^{\circ} \mathrm{C}\right)$ can be converted to degrees Fahrenheit $\left({ }^{\circ} \mathrm{F}\right)$ by the equation:

$$
{ }^{\circ} \mathrm{F}=9 / 5\left({ }^{\circ} \mathrm{C}\right)+32
$$

Sea level: In this report "sea level" refers to the National Geodetic Vertical Datum of 1929-a geodetic datum derived from a general adjustment of the first-order level nets of the United States and Canada, formerly called Sea Level Datum of 1929. 


\title{
GEOHYDROLOGY AND SIMULATION OF GROUND-WATER FLOW NEAR LOS ALAMOS, NORTH-CENTRAL NEW MEXICO
}

\author{
By Peter F. Frenzel
}

\begin{abstract}
An existing model was modified in recognition of new geohydrologic interpretations and adjusted to simulate hydrographs in well fields in the Los Alamos area. Hydraulic-head drawdowns at the Buckman well field resulting from two projected ground-water-withdrawal alternatives were estimated with the modified model.

The Chaquehui formation (informal usage) is the main new feature of recent hydrologic interpretations for the Los Alamos area. The Chaquehui occupies a "channel" that was eroded or faulted into the Tesuque Formation, and the Chaquehui is more permeable than the Tesuque. The Chaquehui is a major producing zone in the Pajarito Mesa well field and to a lesser extent in the Guaje well field.

Model modification included splitting the four layers of the McAda-Wasiolek model (McAda, D.P., and Wasiolek, Maryann, 1988, Simulation of the regional geohydrology of the Tesuque aquifer system near Santa Fe, New Mexico: U.S. Geological Survey Water-Resources Investigations Report 87-4056, 71 p.) into eight layers to better simulate vertical ground-water movement. Other model modifications were limited as much as possible to the area of interest near Los Alamos and consisted mainly of adjusting hydraulic-conductivity values representing the Tesuque Formation, Chaquehui formation (informal usage), and Puye Formation, and adjusting simulated recharge along the Pajarito Fault Zone west of Los Alamos. Adjustments were based mainly on simulation of fluctuations in measured hydraulic heads near Los Alamos.

Two possible alternative plans for replacing Guaje well field production were suggested by Los Alamos National Laboratory. In the first plan (Guaje alternative), the Guaje field would be renewed with four new wells replacing the existing production wells in the Guaje field. In the second plan (Pajarito-Otowi alternative), the Guaje well field would be retired and its former production would be made up by additional withdrawals from the Pajarito Mesa and Otowi well fields. A projection for each of these alternatives was made through 2012 using the new eightlayer model. In the Guaje field, projected hydraulic heads at the end of 2012 were as much as 50 feet lower with the Guaje alternative; in the Pajarito Mesa field, hydraulic heads were as much as 12 feet higher with the Guaje alternative. At the western end of the Los Alamos well field, projected hydraulic heads were about 20 feet higher with the Guaje alternative; at the eastern end of the Los Alamos field, the difference between alternatives was much less. At the Buckman field, projected hydraulic heads were about 2 feet higher with the Guaje alternative because the Buckman field is closer to the Pajarito Mesa field than to the Guaje field.

Ways of improving the understanding of the flow system include developing a more accurate representation of the structure and extent of the Tesuque Formation, Chaquehui formation, and Puye Formation of the Santa Fe Group and obtaining more detailed geologic and hydrologic data for the Chaquehui and Puye. Data that describe water chemistry, hydraulic head, and degree of saturation would be valuable for determining the location and quantity of recharge on the Pajarito Plateau, especially along the west side of the Plateau and in canyon bottoms. Chloride concentrations in soil at the top of the Bandelier Tuff could be used to verify the concept that evapotranspiration accounts for nearly all precipitation over a large area of the plateau.
\end{abstract}




\section{INTRODUCTION}

Los Alamos National Laboratory (LANL) and the communities of Los Alamos and White Rock, New Mexico, obtain their water primarily from wells drilled into the Puye Formation, Chaquehui formation (informal usage of Purtymun, 1995), and Tesuque Formation of the Santa Fe Group. Because the old wells in the Guaje well field have become unserviceable they are to be replaced or the well field is to be abandoned. If the field is abandoned, additional ground water could be withdrawn from the Pajarito Mesa and Otowi well fields. The relative effects of these two courses of action on hydraulic heads in the Buckman well field, which supplies water to the City of Santa Fe, are also of interest. Additionally, a better understanding of the geohydrologic system in the area near Los Alamos would be desirable to address general environmental concerns, including resource depletion and contaminant transport. In response to these concerns, the U.S. Geological Survey, in cooperation with LANL, an agent of the Department of Energy, conducted a study to evaluate the effects of replacing or abandoning the Guaje wells and to improve the understanding of the geohydrologic system.

\section{Purpose and Scope}

The purposes of this report are to present recent geohydrologic interpretations for the Los Alamos area, a ground-water flow model modified on the basis of those interpretations, estimated hydraulic-head drawdowns at the Buckman well field resulting from two projected ground-water-withdrawal alternatives, and to suggest additional geohydrologic information. The McAda and Wasiolek (1988) model of the Tesuque aquifer system in the Española Basin was modified, and modifications were limited as much as possible to the area of interest near Los Alamos. Drawdown estimates were made using the modified model. One projected alternative, here called the "Guaje alternative," is to continue withdrawals from a renewed Guaje well field using four replacement wells in the same field. The other alternative, here called the "PajaritoOtowi alternative," is to retire the Guaje field and increase withdrawals from the Pajarito Mesa and Otowi well fields. Additional hydrologic information would be needed to model groundwater flow paths with the necessary detail.

\section{Location of the Study Area}

The study area is the same as that of McAda and Wasiolek (1988) and includes approximately 700 square miles of the Española Basin in north-central New Mexico in the eastern part of Los Alamos County, northwestern part of Santa Fe County, and small parts of Rio Arriba and Sandoval Counties (fig. 1). The area of specific interest for this report is the vicinity of the well fields that supply Los Alamos and the Buckman well field, which partially supplies Santa Fe. Although the area of interest is limited, a larger area of the Española Basin was simulated to minimize boundary effects.

Six well fields are in the model area (fig. 2). The Buckman and Santa Fe well fields supply water to Santa Fe. The Guaje, Los Alamos, and Pajarito Mesa well fields supply water to Los Alamos. The Otowi well field, consisting of two wells, is the newest and was added to the Los Alamos supply system in 1993. 


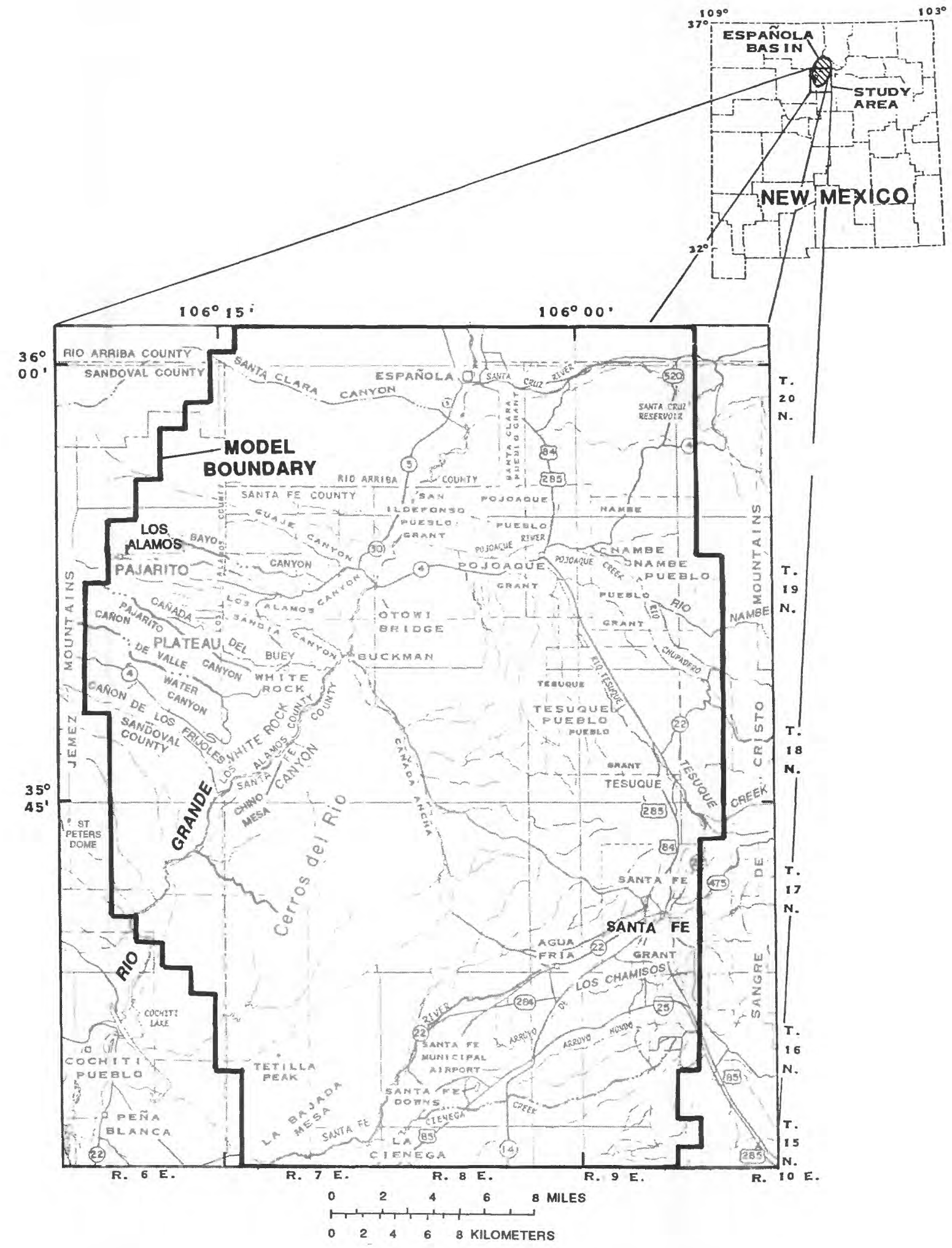

Figure 1.--Location of the study area in north-central New Mexico (modified from McAda and Wasiolek, 1988, fig.1). 

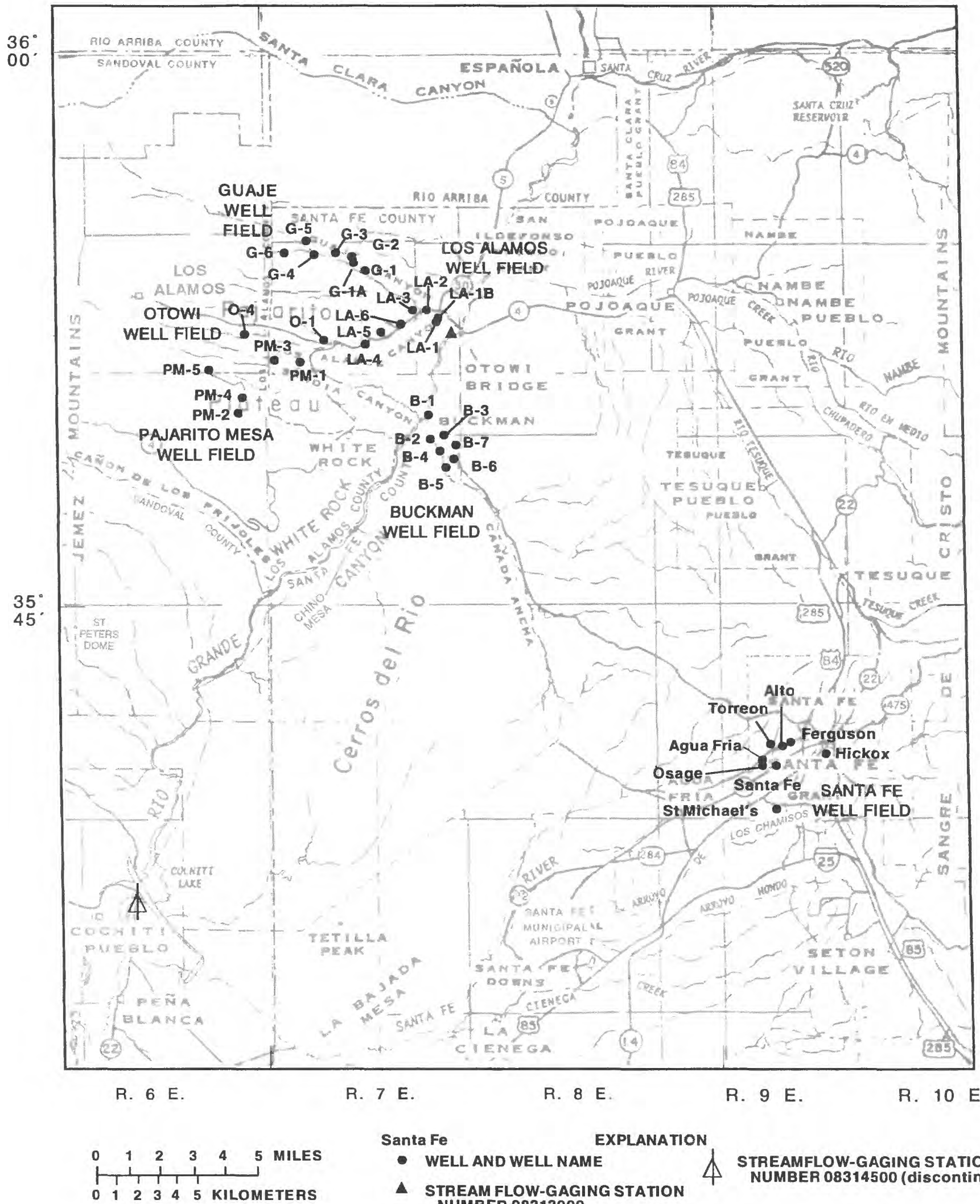

Santa Fe

- WELL AND WELL NAME

A STREAM FLOW-GAGING STATION NUMBER 08313000

Figure 2.--Location of major well fields and selected streamflow-gaging stations in the study area, north-central New Mexico (modified from McAda and Wasiolek, 1988, fig. 2). 


\section{Well-Numbering System}

The system of numbering wells in this report is based on the common subdivision of land into townships, ranges, and sections in the Federal land-survey system. The well numbers based on this system consist of four parts separated by periods (fig. 3). The first part is the township number, the second part is the range number, and the third part is the section number. Because all township blocks within the study area are north of the base line and east of the principal meridian, the letters $\mathrm{N}$ and $\mathrm{E}$, indicating direction, are omitted as well as the letters $\mathrm{T}$ and $\mathrm{R}$ for township and range. Hence, the number 18.7 .1 is assigned to any well located in sec. 1, T. $18 \mathrm{~N}$., R. 7 E.

The fourth part of the number consists of three digits that denote the particular 10-acre tract within the section in which the well is located. The method of numbering the tracts within the section is shown in figure 3 . For this purpose the section is divided into four quarters, numbered $1,2,3$, and 4, in the normal reading order, for the northwest, northeast, southwest, and southeast quarters, respectively. The first digit of the fourth part gives the quarter section, which is a tract of 160 acres. Each quarter is subdivided in the same manner so that the first and second digits together define the 40 -acre tract. Finally, the 40 -acre tract is divided into four 10 -acre tracts, and the third digit denotes the 10-acre tract. Thus, well 18.7.1.224 is in the SE1/4 of the NE1/4 of the NE1/4 of sec. 1, T. 18 N., R. 7 E.

LANL wells are identified by name. The names are the same as those used in LANL reports (such as Purtymun, 1984; Purtymun and others, 1985; and Stoker and others, 1992).

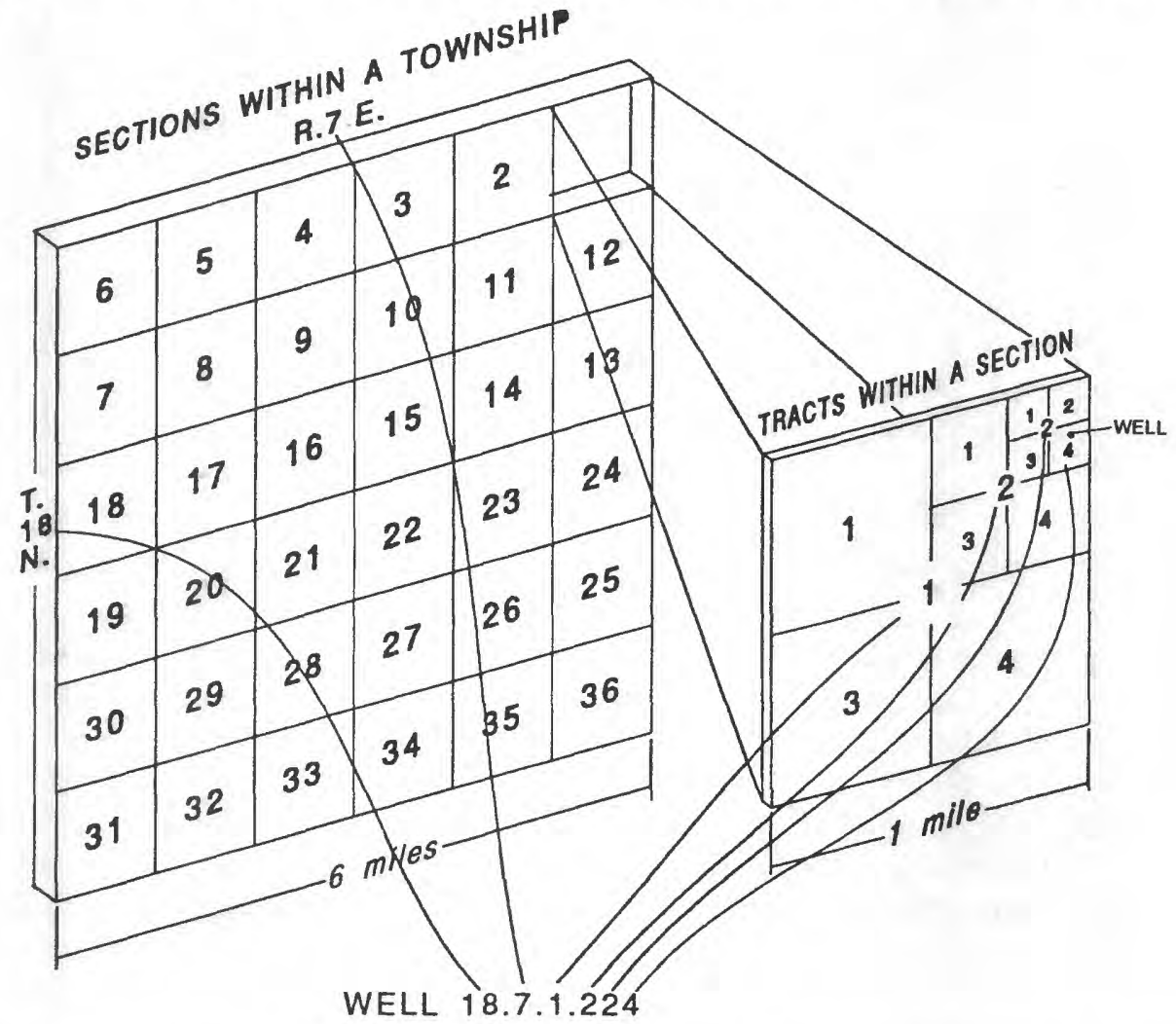

Figure 3.--System of numbering wells based on the Federal land-survey system. 


\section{Acknowledgments}

This study benefitted greatly from the geohydrologic concepts of Bill Purtymun, Alan Stoker, Steve McLin, and Bruce Gallaher of Los Alamos National Laboratory. These individuals also made available much of the literature used in this study and provided well completion, water-level, and pumping records for the LANL wells. The author would also like to thank Tom Morrison, Charles Wohlenberg, Nancy Cunningham, and Dave Esparza of the New Mexico State Engineer Office and Robert Jorgensen of the Sangre de Cristo Water Company for making available well-completion and pumping records.

\section{GEOHYDROLOGY}

The area of the McAda-Wasiolek (1988) model includes the southern two-thirds of the Española Basin (fig. 4), which is one of a series of structural basins along the Rio Grande Rift of Colorado, New Mexico, and Texas. "The Española Basin is a north- to northwest-trending and plunging, asymmetric faulted synclinal sag ***, filled to an unknown depth with semiconsolidated to unconsolidated Tertiary and Quaternary sediments" (McAda and Wasiolek, 1988, p. 7). Precambrian rocks crop out east of the basin in the Sangre de Cristo Mountains (fig. 5). On the west, the Jemez Mountains are composed of Quaternary and Tertiary volcanics.

The Tesuque aquifer system in the Española Basin is composed mainly of the Tesuque Formation, but also includes the Chaquehui formation (informal usage of Purtymun, 1995), and the Puye and Ancha Formations of the Santa Fe Group. The predevelopment potentiometric surface for the upper part of the Tesuque aquifer system (fig. 6) was constructed by McAda and Wasiolek (1988) from maps of six previous works and is thought to represent mainly the water table. The predevelopment potentiometric surface is highest on the east and west sides of the basin and lowest where the Rio Grande exits on the southwest, indicating that ground water generally flows from the east and west to the Rio Grande. The following sections briefly describe the geohydrology of the Española Basin in general, then continue with a more detailed summary of the part of the basin near Los Alamos.

\section{Española Basin}

Detailed descriptions of the geology of the Española Basin have been reported in previous studies (Spiegel and Baldwin, 1963; Griggs, 1964; Galusha and Blick, 1971; Baltz, 1978; Kelley, 1978; Manley, 1978a, 1978b). The geologic setting of the Española Basin was summarized by McAda and Wasiolek (1988, p. 7).

The Española Basin (fig. 4) is defined by Mesozoic or older bedrock highs on all sides. On the northwest a series of faults dropped downward on the southeast separates the Española Basin from the Mesozoic rocks of the Chama Basin. To the north is the Brazos Uplift. On the northeast, the Rio Grande enters the Española Basin from the San Luis Basin through the Embudo Channel, a bedrock constriction. On the east are the Picuris Block, the Sangre de Cristo Uplift, and the Santa Fe Block, where principal outcrops are of Precambrian rocks. To the southeast a northwest-plunging syncline in Mesozoic and older bedrock limits the extent of the Española Basin. To the south is the Cerrillos Uplift and La Bajada Fault. The Rio Grande exits the Española Basin into the Albuquerque Basin through a bedrock constriction on the southwest. On the west the Española Basin is bounded by the Pajarito Fault Zone, downthrown mainly to the east. The Española Basin fill is semiconsolidated and comprises mainly the Tesuque, Puye, and Ancha Formations of the Santa Fe Group of Tertiary age, along with Quaternary and Tertiary volcanics, mainly on the west side. 

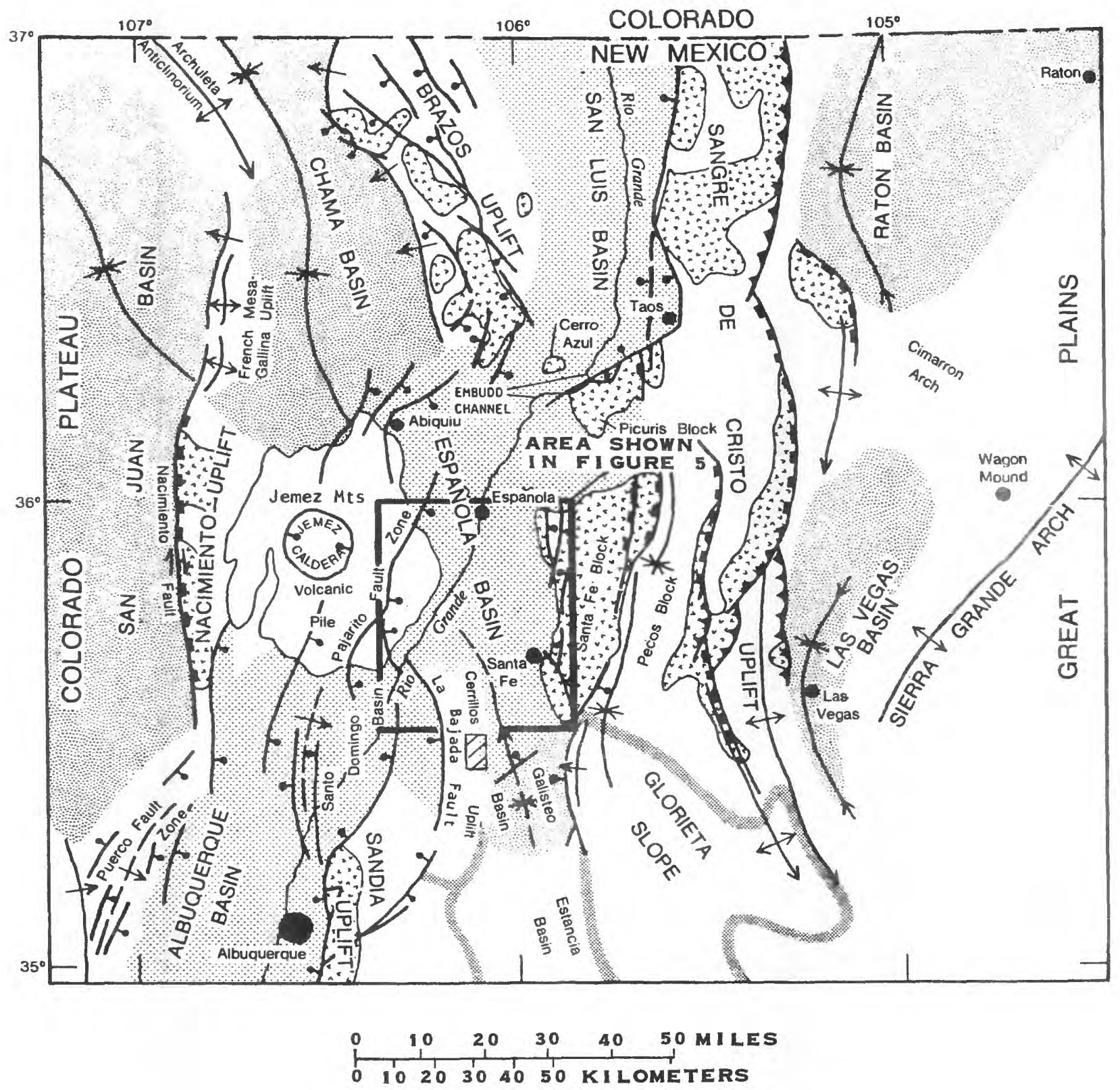

EXPLANATION
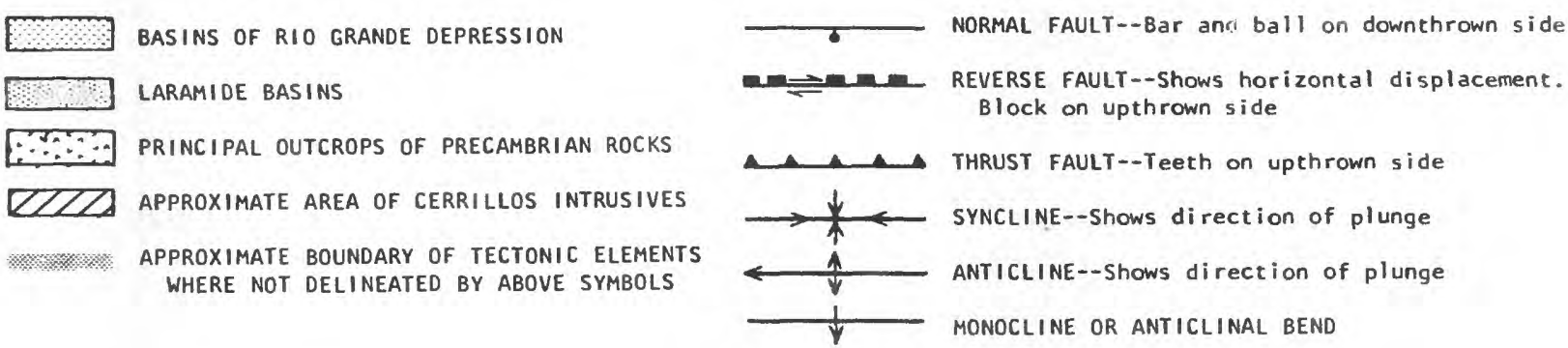

Figure 4.--Major tectonic features of north-central New Mexico (modified from Baltz, 1978, p. 121). 


\section{EXPLANATION}

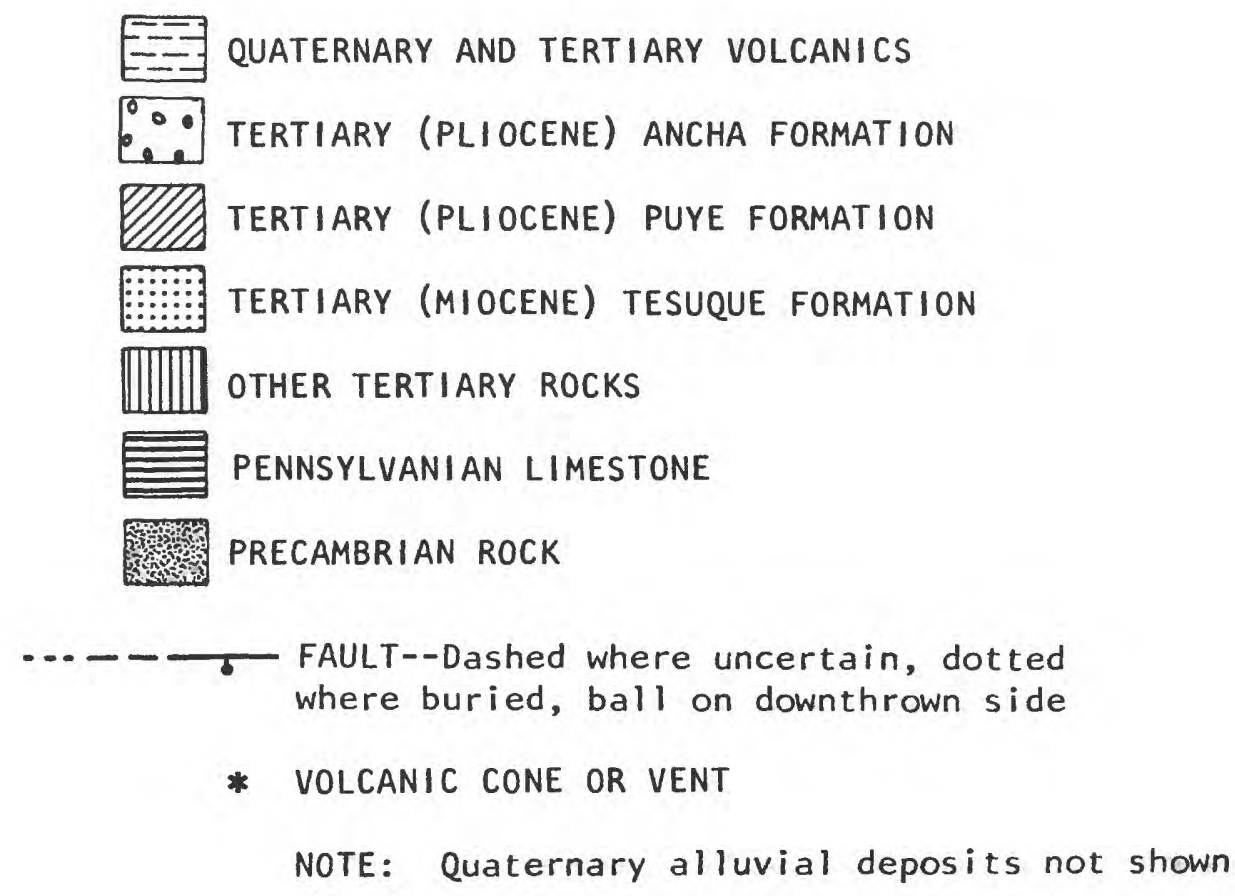

Figure 5.--General geology of the study area, north-central New Mexico (modified from Baltz, 1978; and Kelley, 1978). 

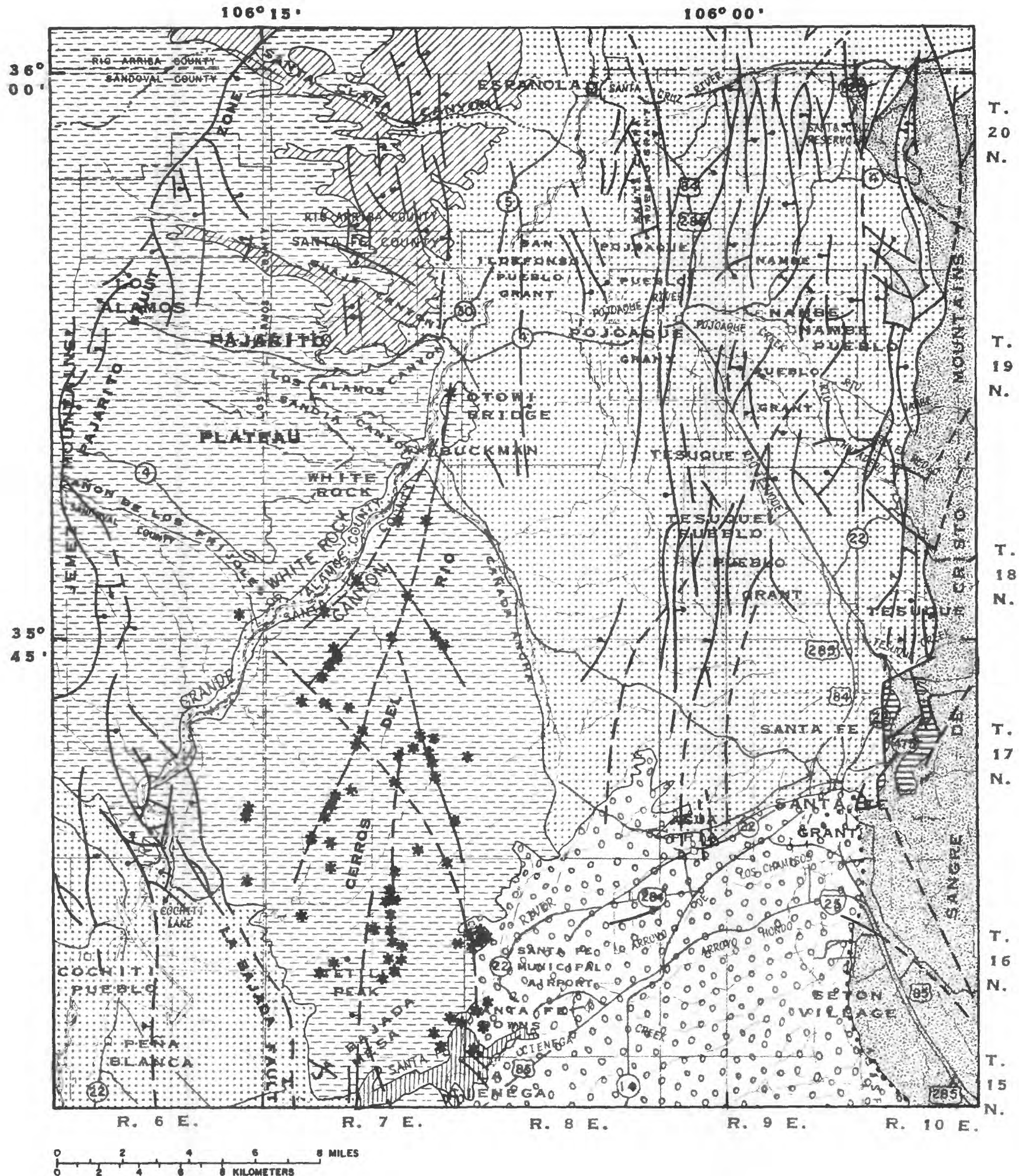


\section{EXPLANATION}

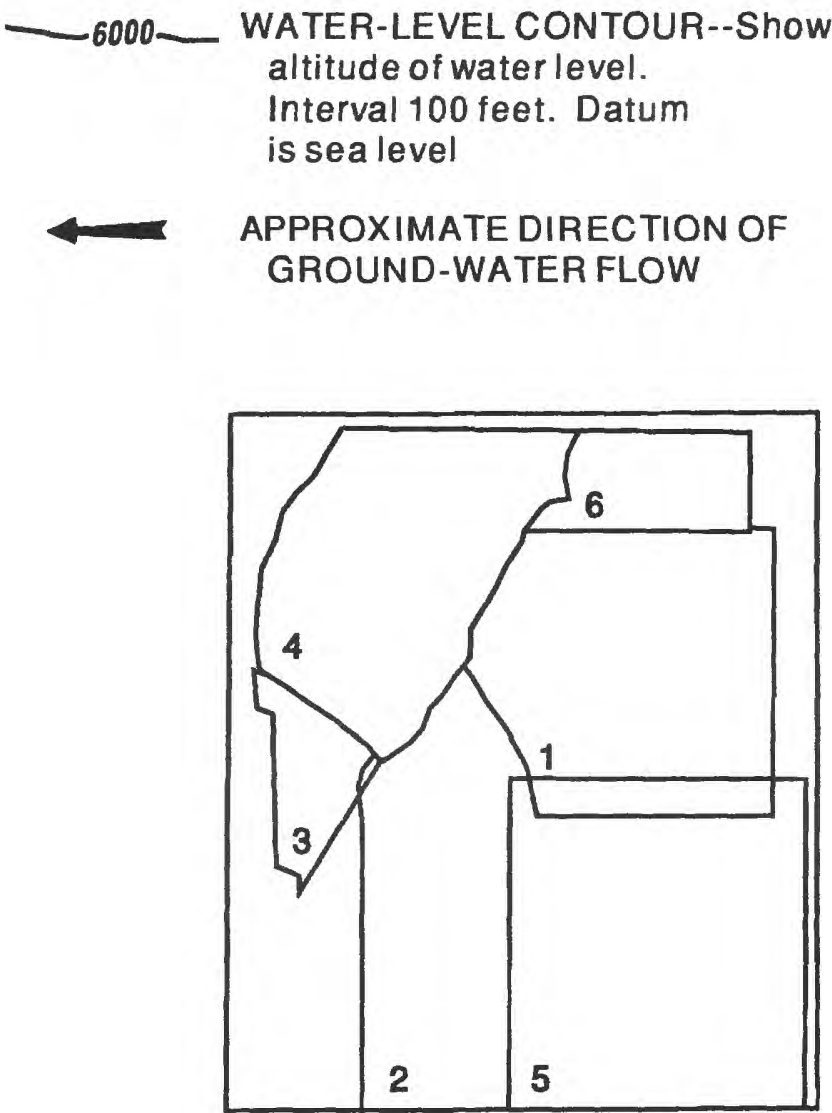

INDEX TO CONTOUR MAPPING

Contours modified from:

1. Borton (1968)

2. Mourant (1980, fig. 3)

3. Purtymun and Adams $(1980$, p. 13)

4. Purtymun and Johansen $(1974$, p. 348)

5. Spiegel and Baldwin (1963, pl. 6)

6. Trauger (1967, fig. 1)

Figure 6.--Predevelopment potentiometric surface in the upper part of the Tesuque aquifer system, north-central New Mexico (modified from McAda and Wasiolek, 1988, fig. 6). 


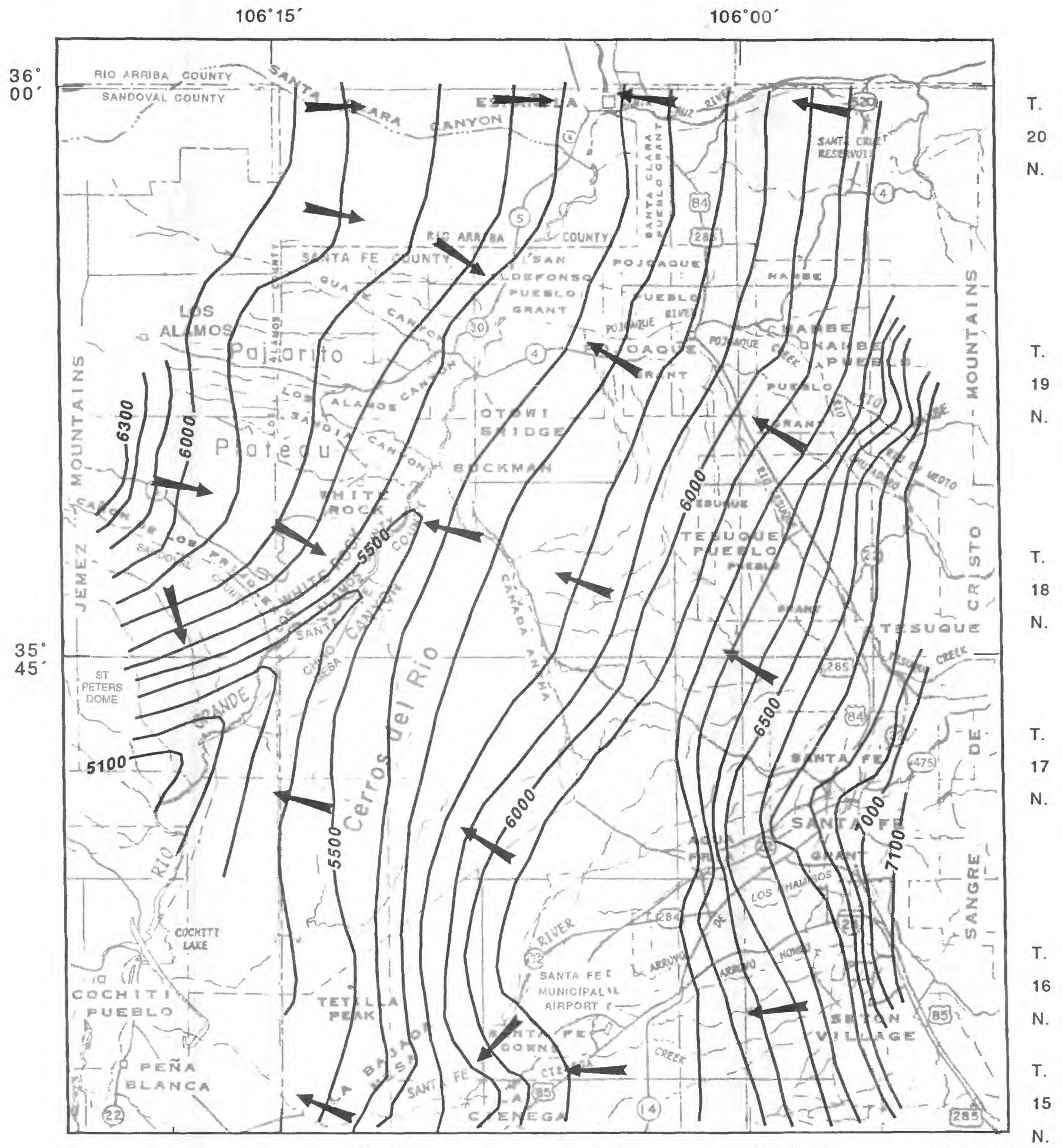
R. $6 \mathrm{E}$.
R. $7 \mathrm{E}$.
R. $8 E$

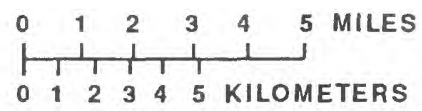

R. $9 \mathrm{E}$

R. $10 \mathrm{E}$. 
The Tesuque Formation is the main aquifer in the eastern and central parts of the study area and was deposited mainly as coalescing alluvial fans derived from the north and east. Tesuque beds generally dip westward 4 to 10 degrees where they are exposed. Steeper dips as great as 25 degrees exist toward the east side of the exposure and less steep dips exist toward the west (Kelley, 1978). Dips are unknown on the west side of the basin where the Tesuque is overlain by younger rocks. Beds of the Tesuque vary in texture from clay to gravel, and are semiconsolidated. Aquifer tests in Public Service Company of New Mexico supply wells indicated hydraulic-conductivity values ranging from 0.2 to 20 feet per day (McAda and Wasiolek, 1988, p. 23). Hearne (1985, p. 8) estimated a range from 0.5 to 2.0 feet per day for the unit at depths likely to be penetrated by wells. McAda and Wasiolek (1988, p. 25) assumed that hydraulic conductivities generally decrease with depth.

The Puye Formation is of an intermediate age between the Tesuque and Ancha. The Puye is discussed in the following section on the geohydrology of the Los Alamos area.

The Ancha Formation of the Santa Fe Group (Spiegel and Baldwin, 1963, p. 45) is present in the southern part of the Española Basin. The Ancha, which overlies the Tesuque Formation, is similar to the Tesuque except that it has a lesser dip (2 to 4 degrees), it is entirely unconsolidated, and it is coarser and better sorted than the Tesuque. The Ancha is largely unsaturated but where it is saturated it probably is more permeable than the Tesuque (McAda and Wasiolek, 1988, p. 12). Ancha-filled channels eroded into the Tesuque form aquifers in the La Cienega area. McAda and Wasiolek (1988, p. 12) assumed that because of its course texture, the Ancha has greater recharge on its outcrop than the Tesuque has on its outcrop. For the purposes of this study, the Ancha is included as part of the Tesuque aquifer system.

\section{Los Alamos Area}

Los Alamos is located on the Pajarito Plateau (fig. 1), a topographic high that slopes gently eastward to the Rio Grande. The Pajarito Plateau is on the eastern slope of the Jemez Mountains, a volcanic pile that rests on and rises above a zone of faults at the western edge of the Rio Grande Depression (Griggs, 1964). The deepest part of the Española Basin may be beneath the Pajarito Plateau, where it could be as deep as 7,500 feet (Budding, 1978). Geologic units underlying the Pajarito Plateau (fig. 7) are mainly the Tesuque Formation, Chamita Formation, Chaquehui formation (informal usage), and Puye Formation of the Santa Fe Group. Although Purtymun (1995), following other authors (primarily Galusha and Blick, 1971), uses the name Puye Conglomerate and considers it to be post-Santa $\mathrm{Fe}$ on the basis of age and lithology, the formal U.S. Geological Survey name is used in this report, which is consistent with McAda and Wasiolek (1988). On the west side of the plateau the Tschicoma Formation interfingers with the Puye and the Tesuque or Chaquehui (Griggs, 1964, p. 18). At land surface over much of the area of the plateau, the Bandelier Tuff overlies the Tschicoma and Puye Formations.

The "main aquifer" in the Pajarito Plateau area of the Española Basin is composed mainly of the Tesuque and Chamita Formations, the Chaquehui formation (informal usage), and the lower part of the Puye Formation. High-yielding wells on the Pajarito Plateau have been developed where a thick section of Chaquehui formation has been penetrated. The altitude of the water table increases westward from the Rio Grande. The water table is in the Tesuque near the river but to the west it is in the Puye beneath the central and western parts of the plateau. Near the western part of the plateau, the water table probably is also in the Tschicoma, which intertongues with the Puye. Because the aquifer discharges to the Rio Grande, the hydraulic head at depth is above land surface near the Rio Grande and in the lower part of Los Alamos Canyon where wells in the Los Alamos well field originally flowed. Aquifers that are to some degree perched exist in places in the Tschicoma and in the alluvium that overlies the Bandelier near some of the streams. 


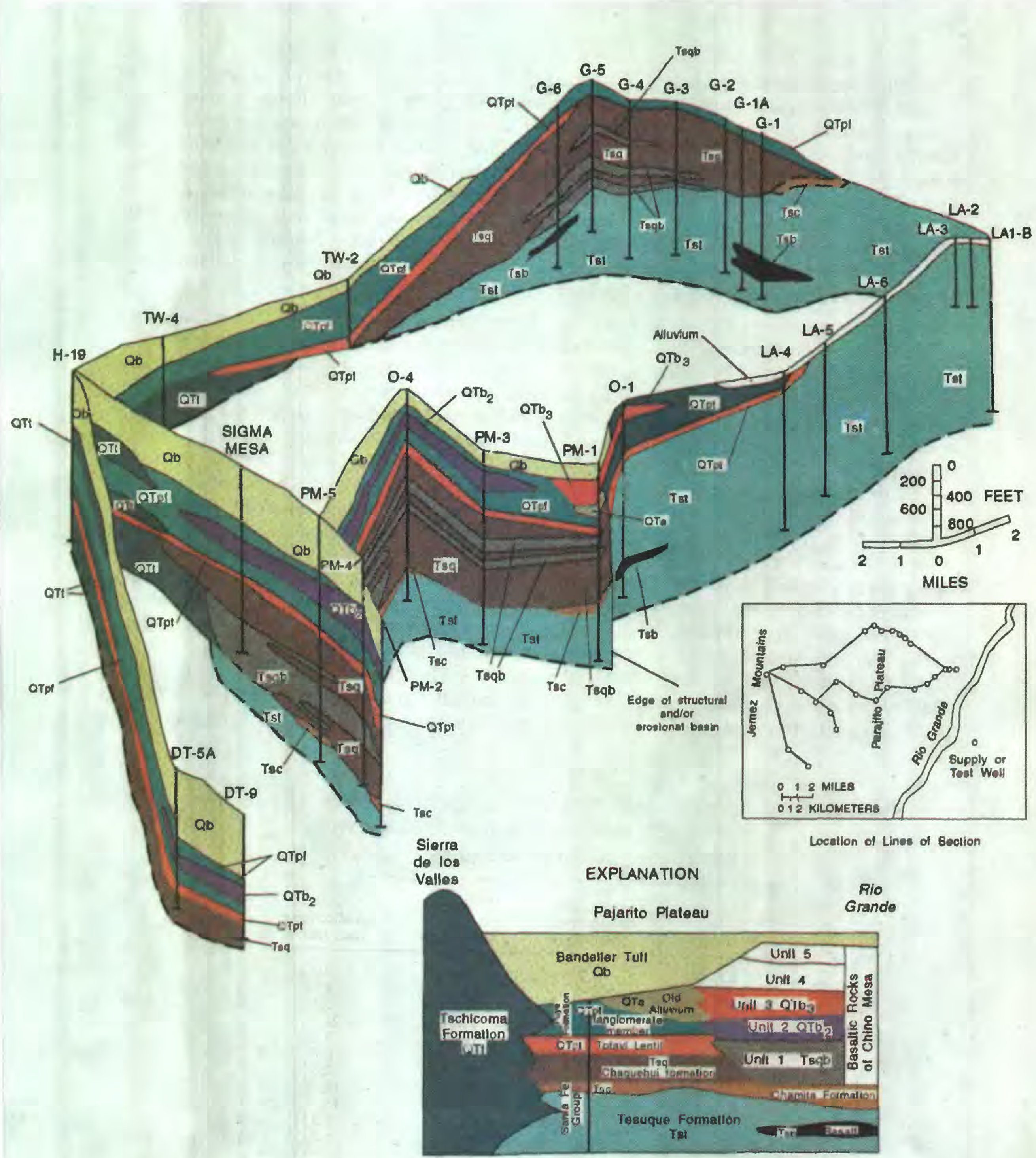

Stratigraphy beneath the Pajanito Plateau

Figure 7.--Fence diagram of the Pajarito Plateau, north-central New Mexico (modified from Purtymun, 1995). 
The Pajarito Plateau is underlain at depth by the Tesuque Formation of the Santa Fe Group (Kelley, 1978) or similar rocks that possibly extend west of the plateau. On the west side of the Pajarito Plateau, the boundary of the basin, for the purpose of this study, is marked by the Pajarito Fault Zone, consistent with Hearne (1985) and McAda and Wasiolek (1988). However, Kelley (1978) showed the Tesuque extending beneath the volcanic rocks west of the Pajarito Fault Zone. Near the southern end of the Pajarito Plateau, St. Peter's Dome (fig. 5), an uplifted block of older rocks, marks the southwestern boundary of the Española Basin, and occurrence of the Tesuque Formation beyond that point is not of concern to this study. The dip of the Tesuque, which is predominantly westward elsewhere in the basin, is generally unknown beneath the Pajarito Plateau because the Tesuque is mostly not exposed.

Aquifer characteristics of the Tesuque Formation of the Santa Fe Group have been estimated at wells completed exclusively in the Tesuque in the Los Alamos well field. Estimated horizontal hydraulic-conductivity values (Purtymun, 1984, app. A), listed in table 1, were derived by dividing the transmissivity by the open interval of the well. These wells penetrate an average saturated thickness of about 1,300 feet, and the estimated average horizontal hydraulic conductivity is 0.7 foot per day. Well Otowi-1 (well O-1 in table 1), also completed in the Tesuque, has an estimated horizontal hydraulic conductivity of 0.8 foot per day. Vertical hydraulicconductivity values were not estimated; however, the ratio of vertical to horizontal hydraulic conductivity for the Tesuque has been estimated to be between 0.04 and 0.001 (McAda and Wasiolek, 1988, p. 27). Specific storage (artesian, elastic conditions) and specific yield (water-table conditions) have not been estimated for the Los Alamos well field. A storage coefficient of 0.088 was estimated from pumping test data at well 0-1 on the basis of a 1-foot well radius, and was considered to be "characteristic of specific yield" (Purtymun and others, 1993). This storage coefficient, when divided by the length of the screened interval of the well, results in a value of $6 \times 10^{-5}$ per foot, more than 10 times the expected value of specific storage for artesian conditions, which might be about $1 \times 10^{-6}$ per foot (Lohman, 1972). The specific yield for semiconsolidated sediments such as the Tesuque might range from about 0.1 to 0.3 (Johnson, 1967, p. 1). McAda and Wasiolek (1988) used a specific yield of 0.15 and specific storage of $1 \times 10^{-6}$ per foot for the Tesuque.

Table 1.--Estimated horizontal hydraulic conductivity in Los Alamos National Laboratory production and selected test wells [Well locations shown in figures 2, 7, and 17]

\begin{tabular}{cccc}
\hline Well name & $\begin{array}{c}\text { Estimated } \\
\text { hydraulic } \\
\text { conductivity } \\
\text { (feet/day) }\end{array}$ & Well name & $\begin{array}{c}\text { Estimated } \\
\text { hydraulic } \\
\text { conductivity } \\
\text { (feet/day) }\end{array}$ \\
\hline LA-1B & 1.2 & G-6 & 0.9 \\
LA-2 & 0.5 & PM-1 & 4.1 \\
LA-3 & 0.4 & PM-2 & 3.7 \\
LA-4 & 0.6 & PM-3 & 24. \\
LA-5 & 0.4 & PM-4 & 3.2 \\
LA-6 & 1.2 & PM-5 & 0.7 \\
G-1 & 0.9 & DT-5A & 2.3 \\
G-1A & 1.2 & DT-9 & 16. \\
G-2 & 1.2 & DT-10 & 15. \\
G-3 & 0.7 & O-1 & 0.8 \\
G-4 & 1.5 & O-4 & 5.7 \\
G-5 & 1.2 & & \\
\hline
\end{tabular}


The Chamita Formation of the Santa Fe Group was first defined by Galusha and Blick (1971). However, Kelley (1978) mapped the Chamita with the underlying Ojo Caliente Sandstone Member of the Tesuque Formation, which Galusha and Blick (1971) considered to be the uppermost member of the Tesuque. Like the Tesuque, the Chamita consists of siltstones, sandy siltstones, and sandstones and was derived from the highlands to the north. The Chamita is thickest in the northern part of the Española Basin but thins southward to less than 30 feet near the Otowi Bridge (fig. 1). The Chamita is absent in the Guaje well field and was eroded away or never deposited in the Los Alamos area (Purtymun, 1995). Because the lithologic and hydrologic characteristics of the Chamita are similar to those of the Tesuque and because the Chamita is thin or absent (fig. 7), the Chamita Formation in the Pajarito Plateau is considered in this report to be hydrologically part of the Tesuque, consistent with McAda and Wasiolek (1988). Aquifer characteristics of the Chamita are unknown but assumed to be the same as those of the Tesuque.

Rocks here called the Chaquehui formation of the Santa Fe Group (informal usage of Purtymun, 1995) were first noted but not named by Griggs (1964) during the construction of the Guaje well field. This thick section of rocks occupies the upper part of what he called the undifferentiated unit of the Santa Fe Group. The undifferentiated unit is mostly Tesuque Formation; however, unlike the Tesuque, the upper part of the undifferentiated unit is made up of volcanic debris from the west and granitic debris from the north and east. Purtymun (1995) separated this section of course-grained volcanic and granitic sediments from the Tesuque and Chamita Formations of the Santa Fe Group on the basis of geologic logs, geophysical logs, and well cuttings, calling it the Chaquehui formation. Interbedded in the Chaquehui are basalts thought to have originated east of the Rio Grande (W.D. Purtymun, oral commun., September 1994). The interbedded basalts, about 8 million years old, are almost as old as the Chamita (Purtymun, 1995).

The Chaquehui formation occupies much of an ancient "channel" eroded or faulted about 1,000 feet into the Tesuque Formation. From well logs, the channel appears to be about 3 to 4 miles wide and trends north-northeast through the Guaje and Pajarito Mesa well fields. This channel seems to coincide with a slightly smaller graben inferred from gravity work by Budding (1978) to be about 6 miles long and 3 miles wide. Although the western extent of the Chaquehui is not precisely known, it was not found at test well TW-4 (fig. 7). On the east side, the Chaquehui ends abruptly between production wells PM-1 and O-1. The northern and southern extremities of the channel are unknown. Found mainly in the subsurface, a thin section of the Chaquehui crops out in White Rock Canyon north of the mouth of Chaquehui Canyon, which is just north of Cañon de los Frijoles (fig. 1). The Chaquehui is partially saturated in the Guaje well field and fully saturated in the Pajarito Mesa well field where W.D. Purtymun (oral commun., 1993) credited the Chaquehui and the Totavi Lentil of the Puye Formation with the relatively larger productivity of that field.

Horizontal hydraulic conductivity of the Chaquehui formation has been estimated in the northern part of the Pajarito Mesa well field and in the western part of the Otowi well field. Wells PM-1, PM-3, and O-4 are completed mainly in the Chaquehui formation and to a lesser degree in the Tesuque Formation. Estimated horizontal hydraulic conductivity (Purtymun, 1984, app. A) averaged 11 feet per day. The average saturated thickness was about 1,700 feet. In the Guaje well field, estimated horizontal hydraulic conductivity (table 1) averaged about 1 foot per day in wells penetrating an average of 1,400 feet of saturated thickness, of which about half is Chaquehui and about half is Tesuque. These estimated hydraulic-conductivity values are for the combined section of Chaquehui, Tesuque, and interbedded basalts. The ability of the basalts to 
transmit water is thought to result from fracturing that occurred at the time of emplacement as interflow breccia zones. These rocks yield water to wells and their hydraulic conductivity is thought (W.D. Purtymun, oral commun., January 6, 1994) to be generally similar to that of the Chaquehui formation. Vertical hydraulic conductivity has not been estimated for the Chaquehui formation. A storage coefficient of $1.93 \times 10^{-3}$ was estimated from pumping test data at well 0-4 on the basis of a 1-foot well radius, and was considered to be representative of a leaky confined aquifer and "consistent with hydrogeological observations from adjacent production wells" (Stoker and others, 1992). This storage coefficient, when divided by the length of the screened interval of the well, results in a value of $1.3 \times 10^{-6}$ per foot, comparable to the expected value of 1 $\times 10^{-6}$ per foot for artesian specific storage. A specific yield has not been estimated for the Chaquehui but may be similar to other semiconsolidated sediments.

The Puye Formation includes the Totavi Lentil and a fanglomerate member, as described by Griggs (1964, p. 28-37). The Totavi Lentil is at the base of the Puye and overlies the Tesuque Formation where the Totavi crops out on the east side of the Pajarito Plateau (Griggs, 1964, p. 29). Within the plateau, the Totavi overlies the Chaquehui formation. The age of the Puye Formation may be less than half that of the Chaquehui. The Totavi is 50 to 60 feet thick and is composed mainly of reworked Precambrian gravel and sand (Kelley, 1978). It is unsaturated in the Guaje well field. The Totavi is also unsaturated where it crops out in Los Alamos Canyon but has springs associated with it farther south in White Rock Canyon. The Totavi is saturated throughout much of the Pajarito Plateau and contributes water to wells in the Pajarito Mesa and Otowi well fields.

The fanglomerate member of the Puye Formation overlies the Totavi Lentil. The thickness of the fanglomerate ranges from the pinch-out near the east side of the Pajarito Plateau to more than 600 feet at well TW-2 (fig. 7). An erosional surface at the top of the fanglomerate prevents determination of its original thickness. The fanglomerate is composed of debris washed eastward from rocks of the Tschicoma Formation and includes mainly sand and silt with gravel and boulders. The coarser material is to the west and the finer material is to the east. Bedding planes dip 1 to 2 degrees eastward, with greater dip angles locally. The fanglomerate member is unsaturated where present in the western end of the Los Alamos well field and in the Guaje well field. It is partially saturated in the Pajarito Mesa well field.

Basaltic rocks of Chino Mesa (fig. 7) are interbedded throughout the fanglomerate member of the Puye Formation (fig. 7). The basaltic rocks of Chino Mesa originated from volcanic centers on Chino Mesa east of the Rio Grande. Griggs (1964, p. 37) described five units, each consisting of more than one basalt flow. Units 1 and 2 also contain basaltic tuffs. The basaltic rocks of Chino Mesa are not known to be cavernous and, as with the older basalts in the Chaquehui formation, their ability to transmit water is considered to result from interflow breccia zones.

Horizontal hydraulic-conductivity values for the individual members of the Puye Formation have not been determined; however, values for a combined section of the Chaquehui formation, the Totavi Lentil of the Puye Formation, and lower part of the fanglomerate member of the Puye have been estimated. The estimated horizontal hydraulic conductivity (Purtymun, 1984, app. A) averages about 2.5 feet per day at wells PM-2, PM-4, and PM-5 in the Pajarito Mesa well field (table 1). The average saturated thickness at these three wells is about 1,700 feet. This estimated horizontal hydraulic conductivity is an "average" for the members of the Puye Formation and Chaquehui formation and the interbedded basaltic rocks of Chino Mesa. At a group of test wells (DT-5A, DT-9, and DT-10), located southwest of the Pajarito Mesa well field, estimated hydraulic conductivity averaged 11 feet per day. This group of test wells penetrates an 
average of 490 feet of saturated thickness, including parts of the fanglomerate member of the Puye, the Totovi Lentil, part of the Chaquehui, and some of the interbedded basaltic rocks of Chino Mesa. Vertical hydraulic conductivity for the Puye has not been determined. Specific yield and specific storage have not been determined for the Puye but they probably have magnitudes similar to those for the Tesuque Formation and Chaquehui formation.

The Tschicoma Formation of Pliocene age and the Bandelier Tuff of Pleistocene age are major volcanic units in the Pajarito Plateau. The Tschicoma Formation interfingers with and is approximately the same age as the Puye Formation (Kelley, 1978). The Tschicoma forms the mountains west of Los Alamos and is present beneath the surface of the western edge of the Pajarito Plateau. It is composed of latite, quartz-latite flows, and pyroclastic rocks, and is not known to be cavernous. The permeability of the Tschicoma, less permeable than the Puye, is thought to result from fractures formed at the time of deposition (W.D. Purtymun, oral commun., 1993-94).

At one test well (TW-4) located northwest of the Pajarito Mesa well field, the hydraulic conductivity of the Tschicoma Formation was estimated to be about 2 feet per day (Purtymun, 1984, p. 16); however, this well was completed in a brecciated zone and may not represent the entire Tschicoma. W.D. Purtymun (oral commun., January 6, 1994) reported that of three wells attempted in the Tschicoma about 4 miles west of Los Alamos, only one produced a limited supply of water from a perched zone; the others were "dry." Specific yield and specific storage of the Tschicoma have not been determined.

The Bandelier Tuff overlies the Tschicoma Formation along the flanks of the mountains and overlies the Puye Formation and basaltic rocks in the remainder of the Pajarito Plateau. The Bandelier is a series of ash flows and ash falls of rhyolitic tuff and caps the Pajarito Plateau. It varies in thickness from about 1,000 feet on the west side of the Pajarito Plateau to about 200 feet on the east side. The Bandelier, along with the upper part of the underlying Puye and possibly the upper parts of the eastern edge of the underlying Tschicoma, generally occupies the unsaturated zone at Los Alamos. Because the water-yielding characteristics of the Bandelier relate mainly to recharge on the Pajarito Plateau, these characteristics are discussed in the following section on recharge.

The Pajarito Fault Zone lies near the western edge of the Pajarito Plateau. South of Los Alamos the Bandelier Tuff on the east side of the fault is downthrown about 300 feet relative to the tuff on the west side of the fauit. Faults along the Pajarito Fault Zone are generally downthrown on the east (Kelley, 1978); however between Los Alamos and Guaje Canyons, several faults are downthrown on the west. Although Hearne (1985), McAda and Wasiolek (1988), and Finch and Fleming (1992) considered the Pajarito Fault Zone to be the western boundary of the Española Basin, the possible westward extent of the Tesuque Formation and its hydraulic continuity westward beyond the Pajarito Fault Zone are unknown. 


\section{Ground-Water Flow, Recharge, and Discharge}

McAda and Wasiolek (1988) constructed a predevelopment potentiometric-surface map (fig. 6) for the Tesuque aquifer system that was based on several maps published by other authors (Spiegel and Baldwin, 1963, pl. 6; Trauger, 1967, fig. 1; Borton, 1968; Purtymun and Johansen, 1974, p. 348; Mourant, 1980, fig. 3; Purtymun and Adams, 1980, p. 13). Any predevelopment map needs to be used with some caution. Generally, by the time enough wells have been drilled in a semiarid region to construct a potentiometric-surface map, the aquifer has been partially developed, and measured water levels, even at newly constructed wells, may not truly represent a predevelopment surface. The maps used by McAda and Wasiolek are a compilation of the work of various authors at various times and therefore may only be assumed to represent predevelopment conditions. If the aquifer is assumed to be horizontally isotropic, the direction of ground-water flow is perpendicular to the potentiometric contours. Water generally flows from the mountains on the west and east sides of the basin toward the Rio Grande, which traverses the basin from northeast to southwest (McAda and Wasiolek, 1988, p. 12-13). Because the Rio Grande is the main receiver of discharge, the hydraulic gradient is upward near the Rio Grande and wells near the Rio Grande may flow.

The Sangre de Cristo Mountains provide recharge to the Tesuque aquifer system as subsurface flow along the mountain front and as percolation from stream channels where they discharge from the mountain front onto the basin. The quantity of water entering the aquifer as subsurface flow along the mountain front was estimated by McAda and Wasiolek (1988, p. 29), as the remainder of precipitation minus evapotranspiration and runoff, to be between 0.7 and 3.0 cubic feet per second per mile of mountain front. The percolation from stream channels where they discharge onto the basin fill along the Sangre de Cristo Mountains was estimated by McAda and Wasiolek (1988, p. 29) from streamflow estimates of other authors (Spiegel and Baldwin, 1963, p. 173-175, 250; Reiland, 1975; and Reiland and Koopman, 1975, p. 9-27) to be about 18 cubic feet per second. No estimates were made by McAda and Wasiolek (1988) for streams discharging from mountains along the west side of the basin.

The Jemez Mountains probably provide some recharge on the west side of the basin as indicated by the potentiometric surface, which slopes generally from the Jemez Mountains to the Rio Grande; however, the quantity attributable to each component and the total ground-water flow through the area are unknown. Components might include subsurface flow from the mountains across the Pajarito Fault Zone into the west side of the Pajarito Plateau, percolation from stream channels that cross the plateau, and areal recharge from precipitation on the plateau.

The age of ground water west of the Rio Grande generally increases from west to east, consistent with a general west-to-east flow direction shown in figure 6. R.R. Spangler (Rust Geotec, written commun., 1993) found that water from the west side of the Pajarito Mesa well field was between 1,000 and 5,000 years old, whereas water from the east end of Los Alamos well field was between 27,000 and 39,000 years old. A.K. Stoker (Los Alamos National Laboratory, oral commun., 1993) suggested, on the basis of gradient and hydraulic properties, that the rate of ground-water movement in the upper part of the main aquifer could be a few tens to a few hundred feet per year. By assuming a distance of 5 to 10 miles, the age of water in the upper part of the aquifer could be less than a thousand years. This wide range of ages is consistent with the existence of relatively new water near the top of the saturated zone and older water deeper in the system. Also, the deeper water in the east end of the Los Alamos well field could conceivably have originated in the Sangre de Cristo Mountains on the east, a possibility that is suggested also by oxygen-18 and deuterium analyses. 
Fraser Goff (Los Alamos National Laboratory, written commun., 1991) used concentrations of oxygen-18 and deuterium to postulate that water from the east end of the Los Alamos well field (well LA-1B) might have recharged at altitudes higher than the Jemez Mountains, suggesting the Sangre de Cristo Mountains. He also suggested that waters withdrawn from most of the production wells of the Pajarito Mesa and Guaje fields originated at altitudes lower than the Valle Grande (the floor of the Jemez Caldera), excluding most of the area of the mountains west of the Pajarito Fault Zone, which generally are higher than the Valle Grande. This implies that recharge could be limited to the Pajarito Plateau and a narrow belt of the mountain slope west of the Pajarito Plateau.

Recharge from precipitation is thought to be minor over much of the area of the Bandelier Tuff, which covers most of the Pajarito Plateau (Abrahams and others, 1961). Although porosity ranges from 18 to 52 percent and "field capacity" is around 20 to 40 percent, the Bandelier generally is unsaturated, having a water content of less than 4 percent by volume. Little or no water moves in the Bandelier where the moisture content is less than about 12 percent, according to Purtymun and others $(1989$, p. 5). The generally very low moisture content of the Bandelier probably indicates that evapotranspiration generally equals or exceeds precipitation and that the moisture storage capacity within the root zone is large enough to keep precipitation from percolating beyond the root zone. Purtymun and others $(1989$, p. $3-5)$ reported that the hydraulic conductivity of the Bandelier at saturation ranges from approximately 0.01 to 0.1 foot per day, values comparable to those of silt (Freeze and Cherry, 1979, p. 29); however, a considerable volume of water would be required to increase saturation enough for hydraulic conductivity to approach that of saturated conditions. The range of hydraulic conductivity of the Bandelier at saturation may be much greater than reported because of varying degrees of welding.

Though natural recharge from precipitation may be relatively insignificant on an annual basis, the larger hydraulic conductivity for the Bandelier Tuff at saturation might allow recharge in places where saturation occurs. Given a sufficiently constant, long-term source of water and no confining bed less permeable than the Bandelier, a saturated zone extending through the Bandelier and into the water table in the Puye Formation is quite possible. Flow would then be controlled largely by the hydraulic conductivity under saturated conditions along the flow path, which would allow more recharge of the main aquifer than would occur under unsaturated conditions. This saturated condition could have occurred in canyons before water was diverted for Los Alamos public supply, probably where canyons enter onto the western side of the Pajarito Plateau, or where there is a "perched aquifer" of long duration in the alluvium. The quantity of main aquifer recharge by this route has not been estimated. The age $(1,000$ to 40,000 years) of water in production wells, which tend to be located in the lower reaches of canyons, seems to indicate little or no recharge in these lower reaches.

Another possible route of recharge is along the Pajarito Fault Zone. The quantity of recharge by this route has not been estimated.

Recharge over the area of the Santa Fe Group is unknown but also probably small. Although Lee Wilson and Associates (1978, p. 1.62) considered 0.28 inch per year to be a low estimate of recharge to the aquifer from the area covered by the Santa Fe Group, Anderholm (1994) concluded on the basis of chloride profiles in the soil that there is no recharge except in sandy arroyos. McAda and Wasiolek (1988) theorized that surfaces on the more course grained geologic units such as the Ancha Formation would have relatively more recharge than the finer grained units such as the Tesuque Formation and the volcanic units in the basin. 
Some streams flowing across the Santa Fe Group lose water to the aquifer in their upper reaches and gain water from the aquifer in their lower reaches. McAda and Wasiolek (1988, p. 43) showed that ground-water recharge from the Pojoaque River and tributaries within the modeled area was about 1.4 cubic feet per second greater than ground-water discharge. They determined this on the basis of the discharge of 14.8 cubic feet per second at the mouth (Reiland, 1975, p. 19), estimated inflow of 17.7 cubic feet per second from outside the modeled area (Reiland, 1975, p. 11 and 17; and fig. 1), runoff of 2.9 cubic feet per second from areas within the modeled area (estimated on the basis of Reiland, 1975, p. 19), and evapotranspiration of 4.4 cubic feet per second within the modeled area (Hearne, 1985, p. 13).

Although the amount of ground-water discharge along the entire length of the Rio Grande within the modeled area (between Española and a point about 4 miles upstream from Cochiti Pueblo) is unknown, streamflow gain has been estimated for the reach between streamflow gages at Otowi Bridge (station 08313000) and near Cochiti Pueblo (station 08314500) (fig. 2). Estimates by Spiegel and Baldwin (1963, p. 200-201) of 25 cubic feet per second over a 26-mile reach ( 0.96 cubic foot per second per mile) between the streamflow gages at Otowi Bridge and near Cochiti Pueblo and by Griggs (1964, p. 95) of 500 to 600 gallons per minute per mile (1.1 to 1.3 cubic feet per second per mile) in a 21 -mile reach downstream from Otowi Bridge are consistent except for a different estimated river mileage. Gains in discharge between the Otowi Bridge streamflow gage and Cañon de los Frijoles were reported to range from 6 to 29 cubic feet per second and to average 15 cubic feet per second by W.D. Purtymun (U.S. Geological Survey, written commun., 1966) and by Purtymun and Adams (1980, p. 5). Ground-water discharge to the Rio Grande is probably the sum of gain in streamflow and loss to evapotranspiration. Almost the entire Otowi Bridge to Cochiti Pueblo reach is in White Rock Canyon where McAda and Wasiolek (1988, p. 44) estimated that the loss to evapotranspiration "*** probably is not more than about 3 cubic feet per second." Thus, ground-water discharge to the reach from Otowi Bridge to Cochiti Pueblo could be in the range of about 10 to 30 cubic feet per second.

\section{Ground-Water Withdrawals and Changes in Recharge}

Most ground-water withdrawals within the modeled area are from well fields that supply Los Alamos (Los Alamos, Guaje, Pajarito Mesa, and Otowi well fields) and Santa Fe (Santa Fe and Buckman well fields). Before 1947, Los Alamos was supplied by surface water from five canyons: Guaje, Los Alamos, Pajarito, Cañon de Valle, and Water Canyon. The larger streamflows continue to support some irrigation needs. Los Alamos well field began producing in about 1947 (fig. 8A) and went out of service for municipal supply during 1992; it provided a temporary supply for road construction during 1993. The Guaje well field began producing in 1950 and the Pajarito Mesa field in 1965. Wells in the new Otowi well field came on line during 1993. The Santa Fe well field began producing in about 1950 (fig. 8B) and the Buckman well field in about 1972. Before the 1950's, Santa Fe was supplied by surface water from the Santa Fe River, which continues to supply a significant part of Santa Fe's needs, depending on the weather. The variable availability of surface water in Santa Fe probably explains the variability in groundwater withdrawals there. Also shown in figure 8B are estimated withdrawals for individual wells that are not included in the well fields, but for which records are available in the New Mexico State Engineer Office. Comparison of graphs shown in figure 8 indicates that estimated withdrawals from wells outside major well fields constitute about 10 percent of total withdrawal from all wells. 


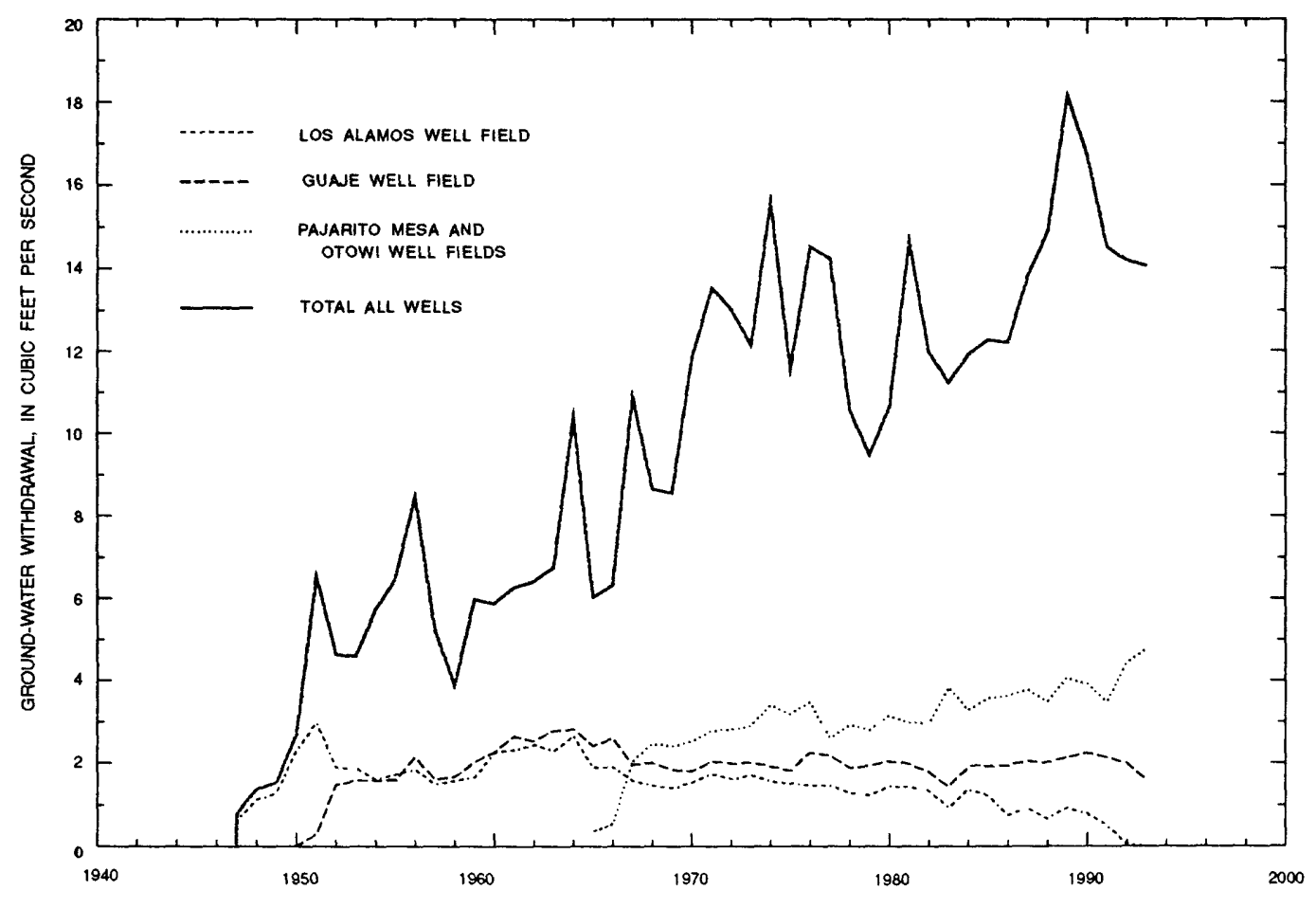

A. Los alamos National laboratory Well fielos ano total for the española basin

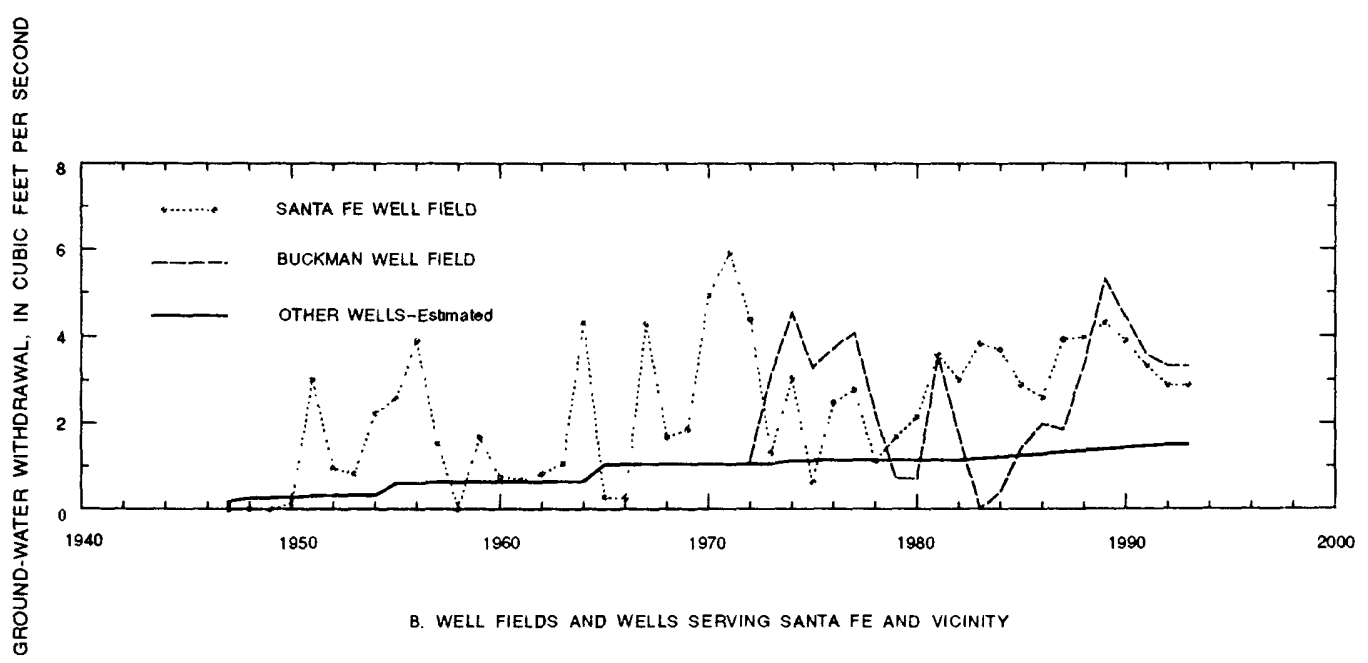

Figure 8.--Ground-water withdrawals from well fields and estimated withdrawals from individual wells in the Española Basin, north-central New Mexico. 
Annual withdrawals from individual wells were estimated if records were not available. Thus, the quantities shown in figure 8 are based mostly on reported values but include some estimated quantities. McAda and Wasiolek (1988, p. 45) determined ground-water withdrawals for 1947-82 and identified the source of reported values and the assumption used to determine estimated values.

For 1983-92, records of ground-water withdrawals from wells in the well fields were obtained from the State Engineer Office and from Los Alamos National Laboratory. Pumping records for individual wells in the Buckman well field were not available for 1987 and 1988. Total pumpage for 1987 was prorated between wells B-1 and B-2 in the proportions indicated by records for 1986. Similarly, total pumpage for 1988 was prorated among wells B-1 through B-6 in the proportions indicated by records for 1989. Annual withdrawals from wells not included in the major well fields were estimated to have increased from 1983 to 1992 at the same rate as the population growth of Santa Fe County between 1980 and 1990.

As understanding of the geologic framework of the main aquifer at Los Alamos improved, ground-water supplies were developed first near the Rio Grande, then westward and southward. The first water-supply wells were drilled in Los Alamos and Guaje Canyons at the eastern edge of the Pajarito Plateau. These wells were completed mainly in the Tesuque Formation and produced less than 500 gallons of water per minute. Los Alamos well field produced water entirely from the Tesuque Formation, and the Guaje well field produced water from the lower part of the Chaquehui formation (informal usage) and from the Tesuque. As more water was needed, additional wells were drilled to the west and south, mainly in canyons that cut through the plateau. The Pajarito Mesa wells were completed mainly in the lower fanglomerate and Totavi Lentil Member of the Puye Formation, in the Chaquehui, and in the upper Tesuque. They produced about 1,500 gallons of water per minute (Purtymun and Cooper, 1969). The most recent wells were drilled in the Otowi well field, located among the other three fields. Well Otowi $1(\mathrm{O}-1)$ is completed in the Totavi and in the Tesuque because the Chaquehui is absent. The other Otowi well (O-4) is completed in the same formation as the Pajarito Mesa wells.

Older wells in the Los Alamos and Guaje well fields are being taken out of service. The entire Los Alamos field was out of service as of 1993, and production has been shifted to the Pajarito Mesa and Otowi fields. The first six wells in the Guaje field are scheduled for replacement by four wells interspersed among and to the west of the old wells so that the center of the well field will move about 0.5 mile westward and slightly northward.

Municipal water developments have been accompanied by changes in recharge from predevelopment conditions. Diversion of the Santa Fe River for public supply undoubtedly changed the location and quantity of ground-water recharge along that drainage. Similarly, diversion of the small streams in the canyons of the Pajarito Plateau must have resulted in less streamflow in places and introduced perennial flows in places that formerly were ephemeral, probably resulting in changes in the location and quantity of recharge in those areas. Subsequent ground-water withdrawals likely have resulted in additional treatment-plant effluent and downstream recharge. 
For the Santa Fe River, McAda and Wasiolek (1988, p. 46) considered that predevelopment recharge near the mountain front probably was reduced by the average quantity of surface water diverted for municipal use. The quantity of water diverted was reported by the Sangre de Cristo Water Company. McAda and Wasiolek (1988) estimated ground-water recharge from the Santa Fe River, in cubic feet per second, to have been:

\begin{tabular}{|c|c|}
\hline Predevelopment...7.5 & $1963-67 \ldots \ldots \ldots \ldots . . . .2 .0$ \\
\hline $1947-52 \ldots \ldots \ldots \ldots \ldots \ldots . .4 .5$ & $1968-72 \ldots$ \\
\hline $1953-57 \ldots \ldots \ldots \ldots \ldots . . . .5 .0$ & $1973-77 \ldots \ldots$ \\
\hline $1958-62 \ldots \ldots \ldots \ldots \ldots \ldots . . . . . . . . . .5$ & $1978-82$ \\
\hline
\end{tabular}

McAda and Wasiolek (1988, p. 46-47) described the estimated location and methods of disposal of Santa Fe sewage treatment-plant effluent, which eventually recharges the aquifer. For a time, some was used for irrigation, but recently it has been discharged to the Santa Fe River, where it infiltrates into the aquifer within 1 to 2 miles of the discharge point. McAda and Wasiolek (1988, p. 47) estimated ground-water recharge from sewage treatment-plant effluent, in cubic feet per second, to have been:

\begin{tabular}{|c|c|}
\hline $1947-52 \ldots \ldots \ldots \ldots \ldots$ & $1963-67 \ldots \ldots \ldots \ldots \ldots . . . . . . . . . . .3$ \\
\hline $1953-57 \ldots \ldots \ldots \ldots . . . . . . . . . . .2$ & $1968-72 \ldots \ldots \ldots \ldots \ldots . . . . . . . . . .1$ \\
\hline $1958-62 \ldots \ldots \ldots \ldots \ldots \ldots . . . . . . .3$ & $1973-77 \ldots \ldots \ldots \ldots \ldots . . . . .4 .4$ \\
\hline & $1978-82 \ldots$. \\
\hline
\end{tabular}

For the purpose of this study, the quantity of sewage plant effluent for 1983-92 was assumed to have been 50 percent (Sorensen, 1977) of the sum of Santa Fe surface-water diversions and ground-water withdrawals for public supply. Surface-water diversion data for 1983-91 were obtained from the New Mexico State Engineer Office. In the absence of 1992 surface-water diversion data, the quantity of recharge was assumed to have been the same as in 1991. Estimated annual ground-water recharge from sewage plant effluent for 1983-92 was $5.4,5.5,5.1,5.7,6.4,7.2,7.6,7.1,6.9$, and 6.9 cubic feet per second, respectively.

For the Pajarito Plateau, the destination of sewage treatment-plant effluent has not been determined because of the complexity of the flow systems. The Pajarito Plateau has two major municipal sewage treatment plants, one located in Pueblo Canyon (north of and paralleling Los Alamos Canyon) serving the Los Alamos town site and the other in the lower end of Cañada del Buey serving White Rock. Recharge of the main aquifer from the White Rock sewage-treatment plant is unlikely because it is located near the Rio Grande. The effluent can be observed in a thin, high waterfall tumbling off a massive basaltic rock into White Rock Canyon.

The effluent from the Los Alamos town site sewage treatment plant is discharged to the lower reach of Pueblo Canyon, which is otherwise ephemeral. Effluent-supported flow joins natural flows in Los Alamos Canyon that, during 1992, generally extended approximately to the confluence with Bayo or Guaje Canyons (Los Alamos National Laboratory, 1993, p. 2-25). Some of the effluent temporarily resides in the perched alluvial aquifer, then is consumed by evapotranspiration or flows to the Rio Grande. The main aquifer in the lower 2 miles of Los Alamos Canyon could have been recharged when water levels in the Los Alamos well field were 
drawn down. However, under predevelopment conditions, and after closure of the well field, recharge is not likely because the potentiometric surface of the main aquifer is higher than the canyon bottom. Recharge of the main aquifer is possible immediately downstream from the treatment-plant outfall where there is a downward hydraulic gradient; given enough time, recharge probably will occur at some unknown rate. The time and rate of recharge are probably determined by the water-yielding properties and previous moisture content of the intervening rock. Although recharge could eventually occur, the combination of low hydraulic conductivity and high porosity of the Bandelier Tuff probably have retarded recharge to some unknown extent.

\section{SIMULATION OF GROUND-WATER FLOW}

Although the ground-water flow model was altered from that of McAda and Wasiolek (1988), the same flow equation and computer program were used (the U.S. Geological Survey modular model MODFLOW, by McDonald and Harbaugh, 1988). The flow equation is:

$$
\delta / \delta \mathrm{x}\left(\mathrm{K}_{x} \delta \mathrm{h} / \delta \mathrm{x}\right)+\delta / \delta \mathrm{y}\left(\mathrm{K}_{y} \delta \mathrm{h} / \delta \mathrm{y}\right)+\delta / \delta \mathrm{z}\left(\mathrm{K}_{\mathrm{z}} \delta \mathrm{h} / \delta \mathrm{z}\right)-\mathrm{W}=\mathrm{S}_{s}(\delta \mathrm{h} / \delta \mathrm{t})
$$

where $\mathrm{K}_{x}, \mathrm{~K}_{y} \mathrm{~K}_{z}$ are the hydraulic-conductivity values in the $\mathrm{x}, \mathrm{y}$, and $\mathrm{z}$ directions, respectively;

$\mathrm{h}$ is the hydraulic head;

$\mathrm{W}$ is the volume of water recharged or withdrawn per unit volume per unit time;

$\mathrm{S}_{s} \quad$ is the specific storage of the aquifer material; and

$t$ is time.

For steady-state conditions, this flow equation is solved with specific storage set to zero. The flow equation was solved with the Strongly Implicit Procedure (SIP), the same as that used by McAda and Wasiolek (1988).

The model was adjusted to simulate hydraulic heads, especially those in or near well fields under transient conditions, by modifying the specified values of hydraulic conductivity, recharge, and storage. Each time a modification of hydraulic conductivity or recharge was made, a steady-state condition was calculated to derive preconditional hydraulic-head values for subsequent transient simulations. In the following discussions, the steady-state condition is described with the transient condition; the distinction is made as needed.

\section{Description of the Model and Modifications to the McAda-Wasiolek Model}

The model required specification of a finite-difference three-dimensional grid, hydraulic conductivity and storage characteristics, time periods, and boundary conditions. Some values of the McAda-Wasiolek model were changed during development of the new model. Aquifer characteristics reported in this section are slightly different from those of the McAda-Wasiolek model, but in most cases, the model is the same or similar.

\section{Model Grid}

The three-dimensional rectangular grid was modified in the vertical dimension from that of McAda and Wasiolek (1988), but the grid in the horizontal plane (fig. 9) remained the same. In the vertical dimension (fig. 10), from the top downward, the top layer of McAda and Wasiolek (1988) was split into three layers 200, 275, and 325 feet thick; the second layer was split into two 
layers 475 and 725 feet thick; and the bottom two layers combined were split into three layers $1,000,1,200$, and 1,400 feet thick. The additional layering was needed to improve the simulation of vertical flow; especially to simulate more correctly the location of water-table storage near the top of the flow system and to simulate more realistically the resistance to vertical low from the water table to the open intervals of the deep municipal supply wells.

These specific thicknesses were selected for practical considerations. Although thinner layers might have given better vertical resolution, a water-table layer thinner than 200 feet would have been troublesome because of cells "going dry" as explained in a following discussion. The conversion from the McAda-Wasiolek model was facilitated by keeping individual wells, those not in well fields, in the top layer as in the McAda-Wasiolek model. Construction details of many individual wells are unknown. Those wells for which characteristics are known, however, mostly penetrate no deeper than 200 feet below the water table.

In the horizontal plane, the extent of layers is shown in figure 9 as "active" and, by inference, inactive parts of the model grid. The flow equation is solved only for the active parts of the grid, as explained by McDonald and Harbaugh (1988, chap. 3, p. 15). The extent of layers 1-3 was the same as that of the McAda-Wasiolek (1988) layer 1, and the extent of layers 4-5 was the same as that of the McAda-Wasiolek layer 2. The extent of layer 6 was the same as that of the McAda-Wasiolek layer 3, and the extent of layer 8 was the same as that of the McAda-Wasiolek layer 4. Layer 7, straddling the McAda-Wasiolek layers 3 and 4, has an intermediate extent.

Figure 10 indicates that the deeper model layers might extend farther east than the basin fill but not as far west as the basin fill. However, McAda and Wasiolek (1988) constructed their model on the basis of the geologic interpretations of many authors, whereas the contact between basin fill (Tesuque Formation) and bedrock (Mesozoic-Precambrian rocks) shown in figure 10 reflects the interpretations of only one author (Kelley, 1978). The extent of the model and the extent of basin fill may not coincide at depth because the extent of basin fill is not well known.

\section{Hydraulic Conductivity, Transmissivity, and Leakance}

Model input for MODFLOW requires a horizontal hydraulic conductivity for each cell in layer 1, transmissivity for each cell in layers 2-8, and a leakance for each cell in layers 1-7. Although transmissivity was used in the model for layers $2-8$, the following discussion is in terms of hydraulic conductivity and leakance. Transmissivity was calculated as hydraulic conductivity multiplied by layer thickness. Leakance values were calculated from vertical hydraulic-conductivity values and layer thickness according to equation 51 of McDonald and Harbaugh (1988):

$$
\text { vcont }_{i, j, k+1 / 2}=1 /\left\{\left[\left(\operatorname{delv}_{k} / 2\right) /\left(\mathrm{kz}_{i, j, k}\right)\right]+\left[\left(\operatorname{delv}_{k+1} / 2\right) /\left(\mathrm{kz}_{i, j, k+1}\right)\right]\right\}
$$

where vcont $t_{i, j, k+1 / 2}$ is leakance between a layer $k$ and the underlying layer $k+1$ at row $i$, column $j(\mathrm{~L} / \mathrm{T})$;

delv $_{k}$ is thickness of model layer $\mathrm{k}(\mathrm{L})$;

delv $_{k+1}$ is thickness of the underlying model layer $k+1$ (L);

$\mathrm{kz}_{i, j, k}$ is vertical hydraulic conductivity of the upper layer at cell $\mathrm{i}, \mathrm{j}, \mathrm{k}(\mathrm{L} / \mathrm{T})$; and $\mathrm{kz}_{i, j, k+1}$ is vertical hydraulic conductivity of the lower layer at cell $i, j, k+1(L / T)$. 


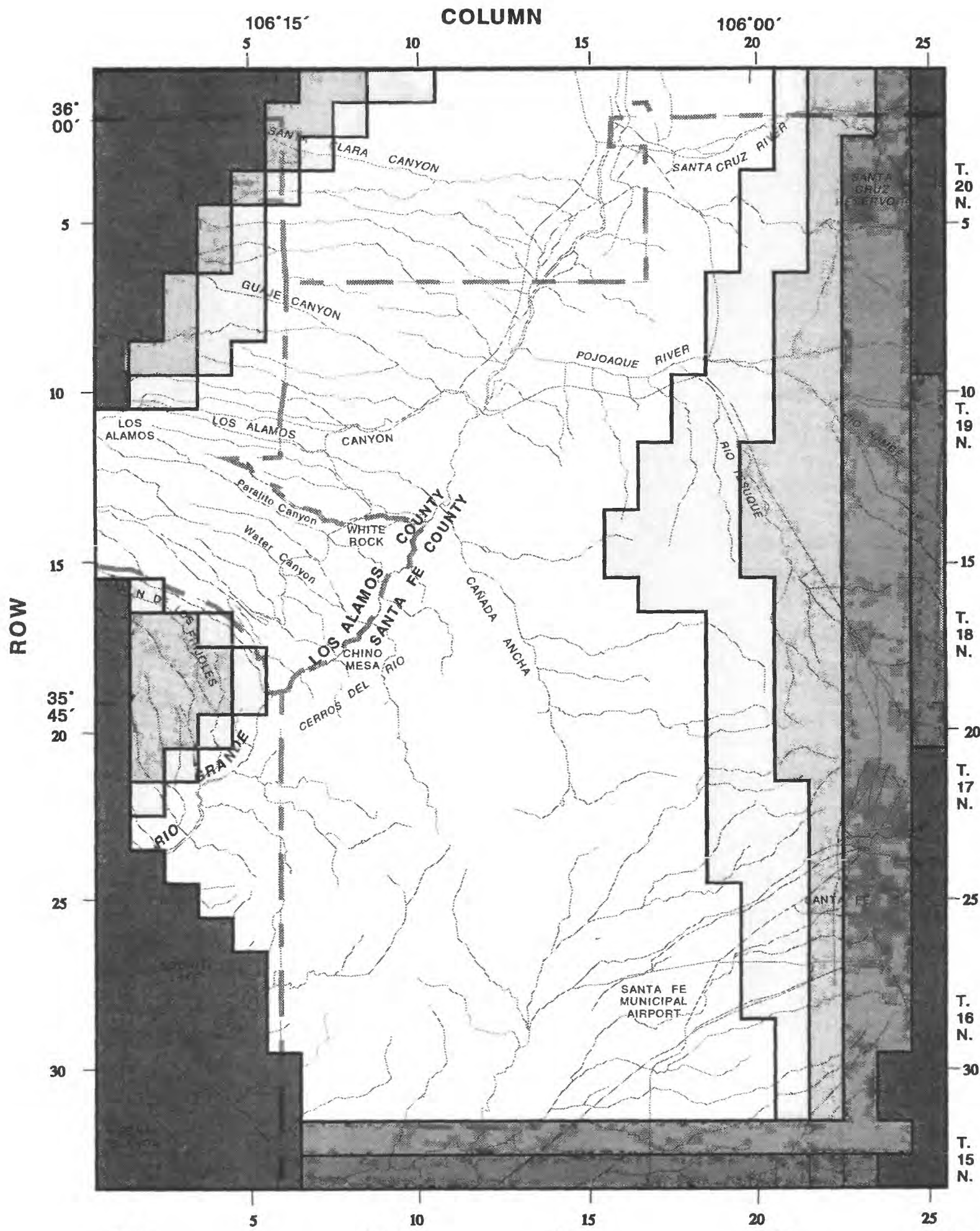

R. $6 \mathrm{E}$.

R. $7 \mathrm{E}$.

R. $8 \mathrm{E}$.

R. $9 \mathrm{E}$.

R. $10 \mathrm{E}$

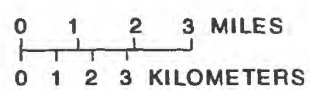

$\begin{array}{ll}\square \text { ALL LAYERS ACTIVE } & \text { LAYERS 1-3 ACTIVE } \\ \square \text { LAYERS 1-7 ACTIVE } & \text { NO LAYERS ACTIVE } \\ \square \text { LAYERS 1-6 ACTIVE } & \text { EXTENT OF ACTIVE } \\ \text { PART OF LAYER }\end{array}$

Figure 9.--Horizontal model grid and extent of layers. 


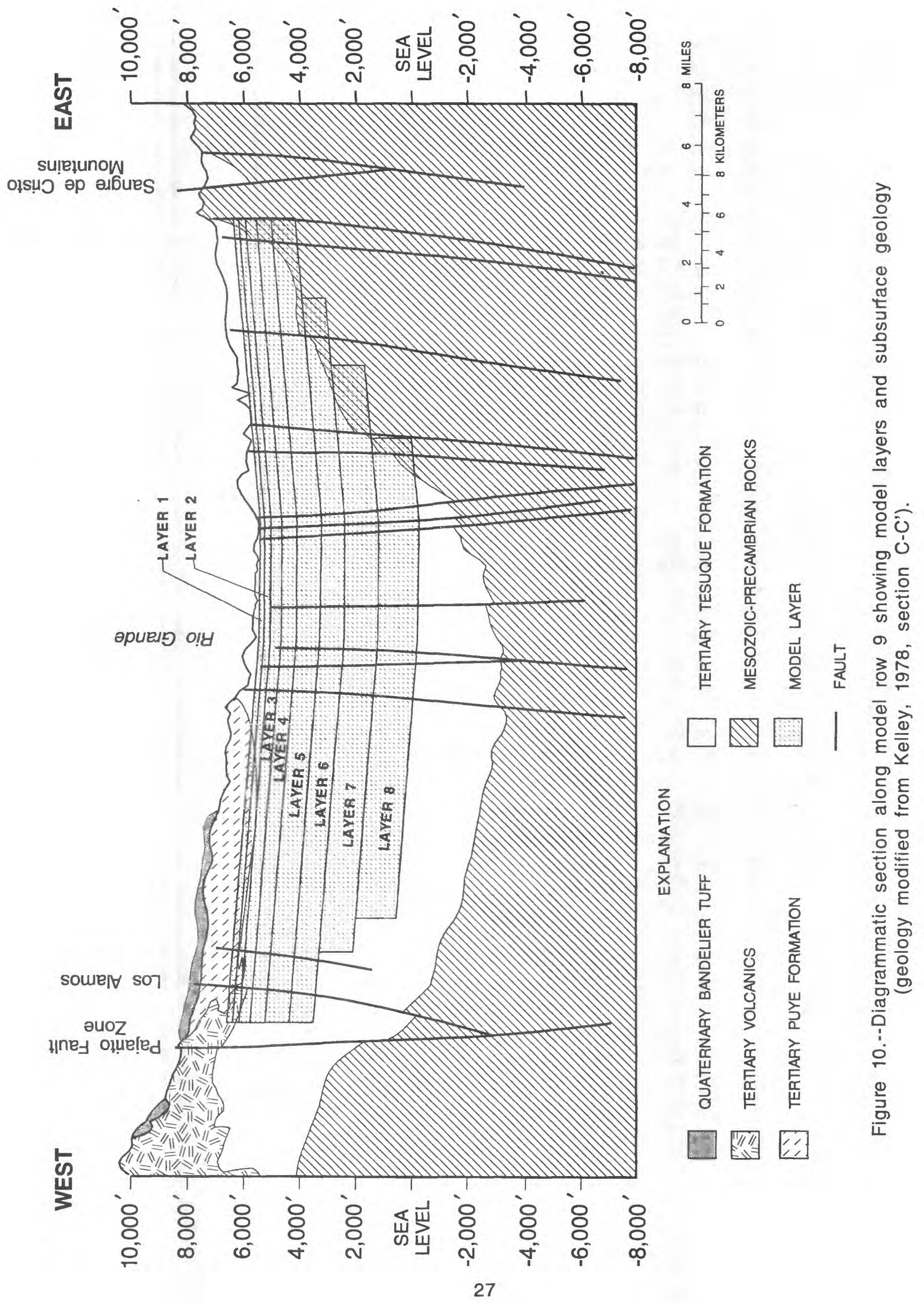


Vertical hydraulic conductivity in each cell was calculated as 0.02 times horizontal hydraulic conductivity, a multiplier developed by model adjustment, which is within the range of 0.04 to 0.001 previously cited for the Tesuque Formation.

Horizontal hydraulic-conductivity values were the same as those of McAda and Wasiolek (1988), with exceptions as described in following paragraphs. That is, the horizontal hydraulicconductivity values of layers 1-3 (fig. 11) were the same as those of layer 1 of McAda and Wasiolek, and the horizontal hydraulic-conductivity values of layers 4 and 5 (fig. 12) were the same as those of layer 2 of McAda and Wasiolek. The horizontal hydraulic-conductivity values of layers 6 and 8 (fig. 13) were the same as those of layers 3 and 4, respectively, of McAda and Wasiolek. Because layer 7 straddled layers 3 and 4 of McAda and Wasiolek, the horizontal hydraulic conductivity of layer 7 , which was 1,200 feet thick, was calculated as $\left(800 \mathrm{~K}_{3}+400 \mathrm{~K}_{4}\right) /$ 1,200 , where $K_{3}$ and $K_{4}$ were the hydraulic-conductivity values of layers 3 and 4, respectively, of McAda and Wasiolek. With one exception, the hydraulic conductivity (not shown) was 0.1 foot per day in layer $6,0.07$ foot per day in layer 7 , and 0.02 foot per day in layer 8 where these layers are active (fig. 9). The exception was in the area near La Cienega where, as in layers 4-5, the hydraulic conductivity was 0.02 foot per day in layers 6-8.

Horizontal hydraulic-conductivity values in the northwestern part of the modeled area (figs. 11-12) were established mainly on the basis of the comparison of long-term measured and model-derived hydrographs in well fields. The area west of White Rock Canyon, where McAda and Wasiolek (1988, fig. 10) represented the Tesuque Formation with a hydraulic conductivity of 0.3 foot per day, was expanded to include the Buckman well field and much of the area west of the Rio Grande. However, at the eastern end of the Los Alamos well field, the hydraulic conductivity representing the Tesuque was 0.1 foot per day in layers 1-5. The hydraulic conductivity representing the Chaquehui formation in the Guaje well field was 0.4 foot per day. The hydraulic conductivity representing the Chaquehui formation and Puye Formation was 5 feet per day in the Pajarito Mesa well field and 2 feet per day southwest of the Pajarito Mesa well field (fig. 11). The Chaquehui, which is largely unsaturated in the Guaje well field, is represented only in layers 1 and 2, whereas in the Pajarito Mesa well field the Chaquehui and Puye are represented in layers 1-4. The hydraulic conductivity representing the interfingering of the Tschicoma Formation with the Puye and Tesuque near the Pajarito Fault Zone was set to 0.3 foot per day because the Tschicoma is generally less permeable than the Puye.

Specified hydraulic-conductivity values are generally somewhat smaller than those estimated from aquifer tests in these well fields. The hydraulic conductivity representing the Chaquehui formation and Puye Formation in the Guaje and Pajarito Mesa well fields is approximately half that estimated from aquifer tests. The hydraulic conductivity representing the Tesuque Formation in the western part of the Los Alamos well field is about half of the average aquifer-test value and, in the eastern part, one-seventh of the average aquifer-test value. This is not an unusual feature of regional models where the size of cells may span local barriers to flow such as faults and changes in lithologic character; thus, hydraulic-conductivity values specified for the model may be to some degree a result of model simplicity. Additionally, aquifertest analyses generally assume full penetration of the aquifer, which is not true of any of the wells tested. Finally, aquifer tests generally do not last longer than several days or weeks, whereas the hydrographs used for model adjustment are decades long. This longer history allows more time for the development of drawdown response to barriers within the aquifer. 


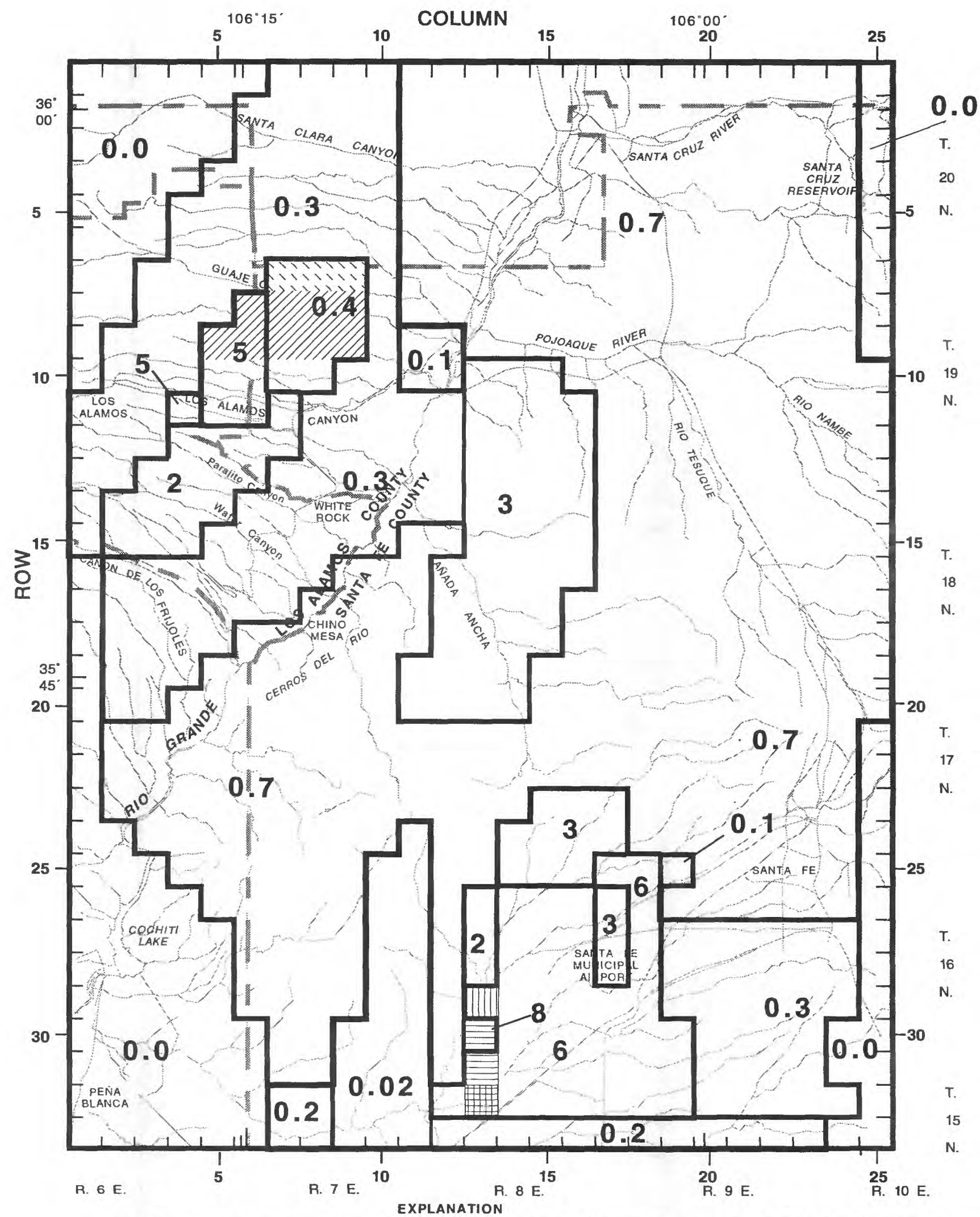

HYDRAULIC-CONDUCTIVITY VALUES FOR LAYERS 2 AND 3 ARE THE SAME AS SHOWN FOR LAYER 1 EXCEPT AS FOLLOWS:

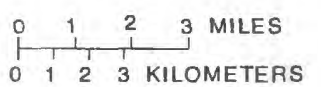

\0.3 FOOT PER DAY (LAYERS 2 AND 3)

ZZA 0.3 FOOT PER DAY (LAYER 3)

IIII] 2 FEET PER DAY (LAYERS 2 AND 3)
0.2 FOOT PER DAY (LAYERS 2 AND 3) 0.7 FOOT PER DAY (LAYER 3)

HYDRAULIC-CONDUCTIVITY BOUNDARY FOR LAYER 1

6 HYDRAULIC-CONDUCTIVITY VALUE, IN FEET PER DAY

Figure 11.--Hydraulic-conductivity values for layers 1-3. 


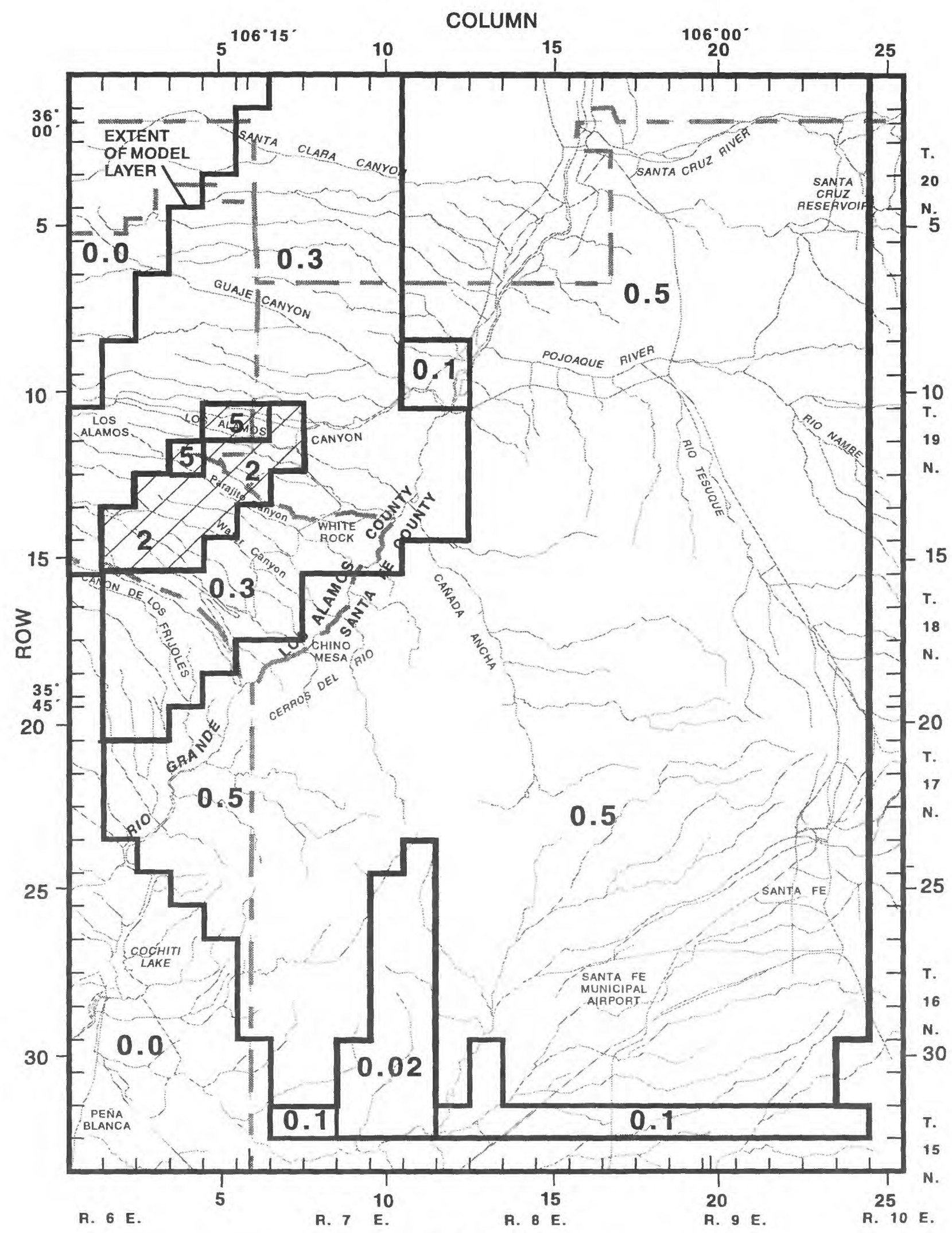

EXPLANATION

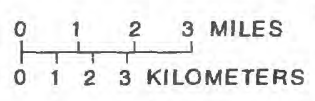

HYDRAULIC-CONDUCTIVITY VALUES FOR
LAYER 5 ARE THE SAME AS THOSE SHOWN

FOR LAYER 4, EXCEPT IN PATTERNED AREA 0.1 HYDRAULIC-CONDUCTIVITY VALUE, IN FEET PER DAY WHERE VALUE IS 0.3 FOOT PER DAY

Figure 12.--Hydraulic-conductivity values for layers 4 and 5 . 


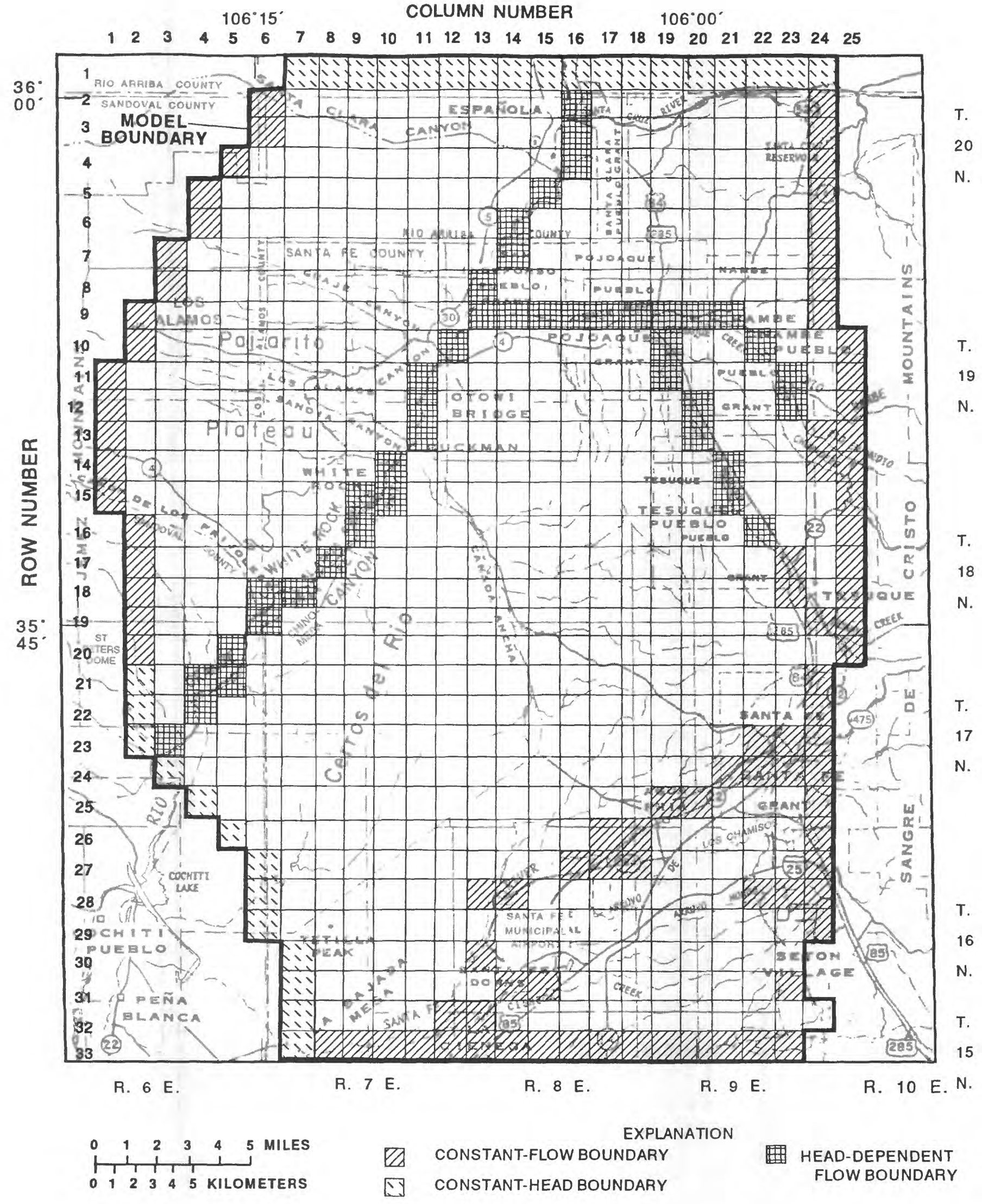

Figure 13.--Boundary conditions represented in layer 1 of the model (modified from McAda and Wasiolek, 1988, fig. 9). 


\section{Specific Yield and Storage Coefficients}

Specific yield and storage coefficients were virtually identical to those of McAda and Wasiolek (1988). In this model, the storage coefficients of layers $2-8$ were derived by multiplying layer thickness times a specific storage of $1 \times 10^{-6}$ per foot. The total storage of both models is very similar; adding the specific yield of 0.15 plus the storage coefficients of layers $2-4$ of McAda and Wasiolek gives a sum of 0.153 , whereas this model has a sum of 0.1554 representing the same aquifer thickness in eight layers.

\section{Initial Condition and Time Periods}

A steady-state condition was used as the initial condition for the transient simulation. As in McAda and Wasiolek (1988), the ground-water system was assumed to be at steady state at the beginning of 1947, the beginning time of the transient simulation. (Municipal ground-water withdrawals began at about that time.) As in McAda and Wasiolek, subsequent stress periods were 1 year long to facilitate the use of annual ground-water-withdrawal data. MODFLOW allows for respecification of ground-water withdrawals each stress period, although the stress period may be subdivided into time steps, at which time model-derived values such as hydraulic heads can be reported (McDonald and Harbaugh, 1988, chap. 8, p. 3). This model used 46 stress periods to carry the simulation through the end of 1992. No annual ground-water-withdrawal data were available for 1993, but a 20-year projection was made from the end of 1992 to the end of 2012. The projection was made using one additional stress period of 20 equal time steps.

\section{Boundary Conditions}

Specified-head, specified-flow, and head-dependent flow boundary conditions were used in this model, as in McAda and Wasiolek (1988). At a specified-head boundary, hydraulic head is maintained and the flow is proportional to gradient and hydraulic conductivity. At a specifiedflow boundary, flow is maintained while the head is proportional to flow and hydraulic conductivity. At a head-dependent flow boundary, flow is simulated as a function of the difference between the hydraulic head simulated for the aquifer and a specified head representing a source or sink such as a river. For the purposes of the following discussion, these general boundary conditions are subdivided and described more specifically. A constant-head boundary is defined for this report as a specified-head boundary that is held constant throughout the time simulated. Similarly, a constant-flow boundary is a specified-flow boundary that is held constant throughout the simulation, whereas the term "specified flow" designates a flow that might be specified at varying levels through the simulation to represent discharge from a well, subsurface inflow, or recharge. Areal recharge is a type of specified-flow boundary at which the flow per unit area is specified in units of length/time (for example, acre-feet per acre per year) and the quantity entering the cell is calculated as the product of the specified value and cell area. A no-flow boundary is a specific instance of a constant-flow boundary. A no-flow boundary is the default condition next to the edge of the model or next to the edge of the area where model cells are active (fig. 9). 


\section{Constant ground-water recharge and discharge}

Ground-water recharge and discharge are represented in the model as constant-head, constant-flow, areal-recharge, no-flow, and head-dependent flow boundaries. These boundary conditions, shown in figure 13, are approximately the same as those of McAda and Wasiolek (1988), except that the specified flows representing recharge from the mountains on the west and flow to or from the sedimentary rocks to the south have slightly different values. Also, where McAda and Wasiolek have boundaries specified in layers 1 and 2, the model herein described has similar conditions specified in layers 1-5.

On the north side of the modeled area, a constant-head boundary simulated flow from or to the northern part of the Española Basin as in McAda and Wasiolek (1988). The boundary shown in figure 13 extended through layers 1-6. The heads specified in the lower layers were the same as in layer 1. Similarly, on the southwest, flow into the Santo Domingo Basin was simulated by a constant-head boundary in layers 1-6.

The constant-flow boundaries representing flow from the mountains along the east and west sides of the modeled area are in layer 1 only. The constant flows along the east side are the same as those of McAda and Wasiolek (1988). The constant flows along the west side were determined, as in McAda and Wasiolek, by first specifying the hydraulic heads in a preliminary steady-state simulation and then using the flows thus derived as constant flows in the subsequent steady-state and transient simulations that are described in this report. Flows along the east side totaled 20.9 cubic feet per second and, along the west side, totaled 10.1 cubic feet per second. Flows at individual model cells are listed in table 5 in supplemental information in the back of the report.

The constant-flow boundary representing flow to and from older sedimentary rocks along the south side of the modeled area was in layers 1-5. Constant flows there were also determined by specifying hydraulic heads in a prior steady-state simulation. Flows at individual model cells were both positive and negative (table 5 in supplemental information) and totaled -1.6 cubic feet per second. The negative sign denotes a net flow out of the modeled area along the south side. The constant-flow boundary was located in row 33 of layers 1-3 as shown in figure 13, and in row 32 in layers 4-5. An exception to the foregoing description of the south boundary was at model row 33, column 23 of layer 1 where a constant head was specified under steady-state conditions. The flow at the constant head was 0.125 cubic foot per second; under transient conditions no flow was simulated.

Constant flows representing recharge from streambeds along the east side of the basin and constant flows simulating springs at La Cienega are the same as those of McAda and Wasiolek (1988). Specified flows (variable) for the Santa Fe River are discussed in the following section.

Areal recharge is shown in figure 14. Recharge on the Pajarito Plateau and on the area of the Tesuque Formation outcrop was decreased to 0.02 during model adjustment as explained in the model adjustment section of this report. Recharge in the rest of the modeled area was the same as that of McAda and Wasiolek (1988).

The head-dependent flow boundaries representing streams are shown in figure 13 . They are the same as those of McAda and Wasiolek. 


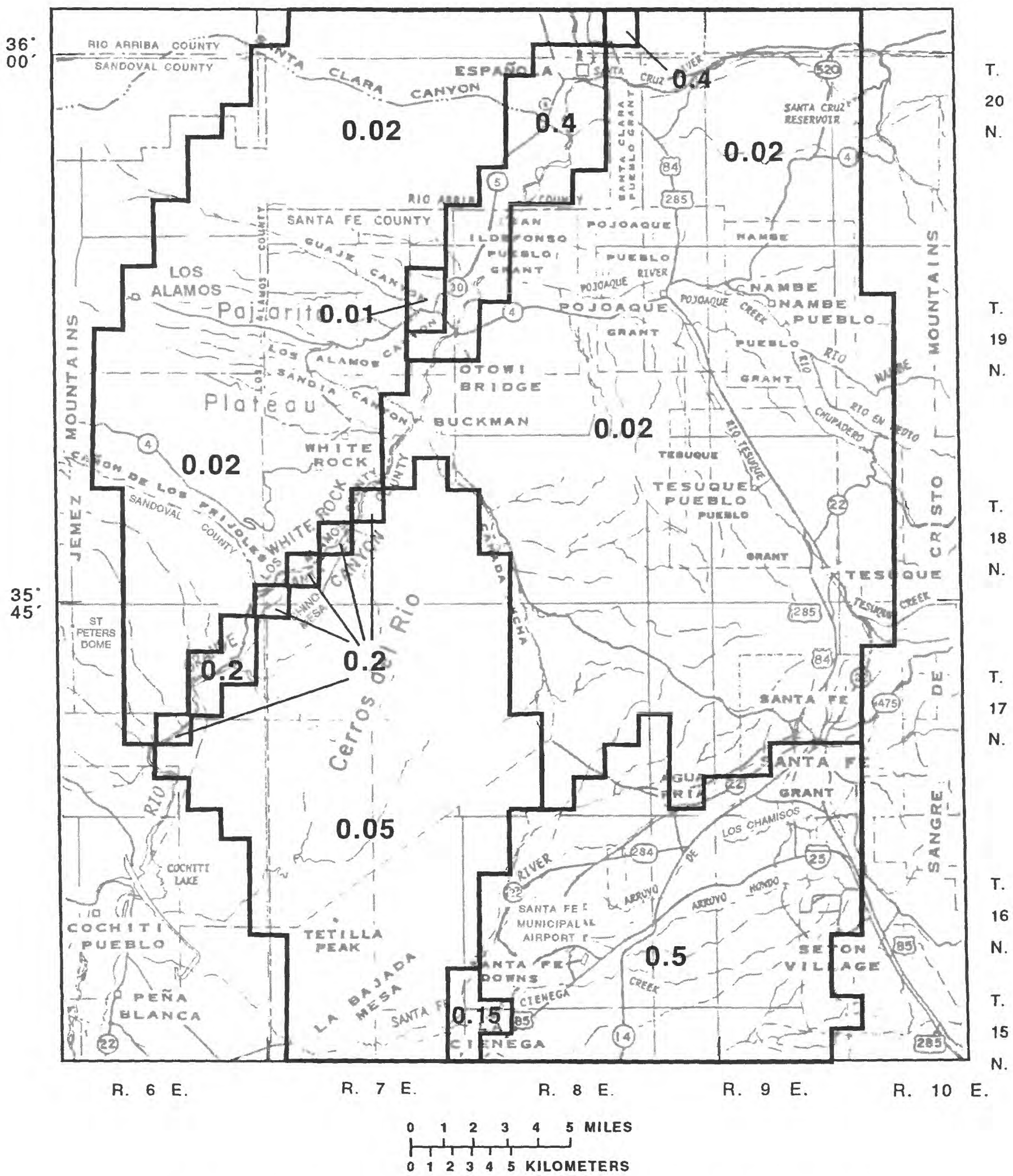

Figure 14.--Distribution of areal recharge in the model, in inches per year (modified from McAda and Wasiolek, 1988, fig. 13). 


\section{Variable ground-water withdrawals and recharge}

Variable ground-water withdrawals and recharge were represented as specified-flow boundaries. Ground-water withdrawal rates at public-supply wells in the five well fields (fig. 8) were specified for each 1-year stress period as given in tables 6-10 in the supplemental data section of this report. Withdrawals were divided between model layers on the basis of the approximate depth of open intervals of the wells below the predevelopment potentiometric surface. For the purpose of this calculation, the predevelopment surface at each well was assumed to be the water-level altitude at the earliest measurement, except in the case of flowing wells where the predevelopment surface was assumed to be approximately at land surface. The percentage of pumpage assigned to each of layers 1-5 for each well is given in table 11 in supplemental information. No pumpage was assigned to layers 6-8 (more than 2,000 feet below the water table).

Ground-water withdrawals at domestic and other wells in the Española Basin were the same as those specified by McAda and Wasiolek (1988) for 1947-82 and were increased each year from 1983 to 1992 at the rate of increase of the population of Santa Fe County. The rate of population increase was estimated on the basis of 1980 and 1990 U.S. Census total county population values. Because these withdrawals from almost 200 wells scattered over the eastern part of the modeled area constituted no more than 10 percent of total ground-water withdrawals and because they were not in the Los Alamos-Buckman area of interest, no new sites were specified. Total withdrawal rates for each stress period at these wells are listed in table 12 in supplemental information.

Recharge along the Santa Fe River was simulated as specified flows by McAda and Wasiolek $(1988$, p. 23) because the river is not perennial over most of its length in the modeled area and the water table is below the riverbed. Recharge varied with time and was simulated with the specified flows given in McAda and Wasiolek (1988, tables 7 and 8), representing recharge from streamflow and sewage treatment-plant effluent for 1947-82. For 1983-92, recharge from streamflow was set equal to values given by McAda and Wasiolek (1988, table 7) for 1978-82, and recharge of Santa Fe sewage treatment-plant effluent was set equal to 50 percent of reported ground- and surface-water withdrawals. The location of recharge from sewage treatment-plant effluent shifted downstream, reflecting changes in plant facilities. For 1983-84, recharge was divided equally among four model cells at row 27, columns 17 and 18 , and row 28 , columns 13 and 14. For 1985-92, recharge was divided equally between two model cells at row 28, columns 13 and 14 .

Changes in recharge along canyon streams on the west side of Pajarito Plateau were not simulated because the mechanism of recharge is not well known. If most recharge is by way of horizontal flow at depth from the Jemez Mountains, it probably does not change much in response to pumpage at well fields. This is probably also true if most recharge is by way of deep percolation along the Pajarito Fault Zone. Also, if most recharge is by way of leakage from perched alluvial aquifers in canyons near the mountain front, a substantial quantity of water would be in transit through the 1,000-foot-thick zone that is unsaturated elsewhere on the plateau. The change in recharge due to diversion of a surface stream might take decades to fully manifest itself on the main aquifer. For example, assuming a complete cessation of streamflow recharge of the perched aquifer, although some diminishment of recharge to the main aquifer might begin soon thereafter, the complete cessation of main aquifer recharge may not occur for a very long time. Similarly, the change in recharge due to establishment of a new or extended perched aquifer downstream from sewage treatment-plant outfall might also take decades to 
fully manifest itself as new recharge to the main aquifer. In view of these uncertainties, the recharge along the Pajarito Fault Zone was held constant at about 10 cubic feet per second through the duration of the simulation.

\section{Other Modifications}

A few modifications were required to allow the McAda-Wasiolek (1988) model to work with eight layers. The simulated hydraulic head in layer 1 dropped below the specified bottom altitude of the layer at some model cells, resulting in the cell "going dry" and no flow being simulated through those cells. Because this occurred near the boundaries in the southern and eastern parts of the model away from the area of interest near Los Alamos and Buckman, two remedies were selected. At La Cienega, where springs were simulated as constant negative flows, the area with larger hydraulic conductivity was extended westward into the spring area. The increased hydraulic conductivity in cells where outflow is simulated prevented excessive lowering of the hydraulic head in those cells. These springs issue from highly permeable materials of limited areal extent, details that are not well simulated by a regional model with milewide cells. The second remedy was to increase the initial saturated thickness by respecifying the bottom altitude of layer 1 at row 30, column 13 to a value 30 feet lower than that of McAda and Wasiolek (1988). The bottom altitude was also lowered along the Sangre de Cristo Mountain front in row 12, column 25 and in row 27, columns 23 and 24 where the bottom altitude was lowered by 50 and 30 feet, respectively. These changes were not considered excessive because they resulted in a smoother bottom surface on layer 1 than that of McAda and Wasiolek. Cells going dry was probably more of a problem with the 200 -foot-thick top layer than it had been with the 800-foot-thick layer.

\section{Model Budget}

The model budget balances at approximately zero (table 2)--that is, inflow equals outflow where storage is considered to be part of inflow and outflow. Under steady-state conditions, there is no storage change. Under transient conditions, water may be simulated as going into storage at one location and coming out of storage in another. Thus storage is listed in table 2 under both headings, inflow (positive values) and outflow (negative values).

The constant-head boundary on the north side of the model did not adversely affect simulated drawdowns because the flows at the boundary did not change greatly during the time simulated. From steady state through the projection, inflow from the constant-head boundary increased and outflow decreased by amounts totaling about 0.3 cubic foot per second or 0.4 percent of the total budget, which is not considered significant.

To show the simulated source of water withdrawn from wells, table 3 lists items from the model budget that change with time. Items that appear in table 2 under both inflow and outflow headings were combined in table 3, which shows net flows for storage, north boundary, southwest boundary, and rivers. Items that were constant through time in table 2 are not shown in table 3. Specified flows simulating recharge along the Santa Fe River ("sewage recharge" and "Santa Fe River" in table 2) were combined as "Santa Fe River recharge" in table 3. 
Table 2.-Model budget

[All flows in cubic feet per second; apparent discrepancies in the tenths place are caused by rounding]

\begin{tabular}{|c|c|c|c|c|}
\hline Budget item & Steady state & $\begin{array}{l}\text { Stress } \\
\text { period } 46 \\
\text { (1993) }\end{array}$ & $\begin{array}{l}\text { Stress period } 47 \\
\text { (2013) Guaje } \\
\text { alternative }\end{array}$ & $\begin{array}{c}\text { Stress period } 47 \\
\text { (2013) } \\
\text { Pajarito-Otowi } \\
\text { alternative }\end{array}$ \\
\hline \multicolumn{5}{|l|}{ Inflow } \\
\hline Storage & 0.0 & 15.5 & 12.6 & 12.7 \\
\hline \multicolumn{5}{|l|}{ Constant head } \\
\hline North boundary & 1.9 & 2.0 & 2.0 & 2.0 \\
\hline Southwest boundary & 0.1 & 0.1 & 0.0 & 0.0 \\
\hline South boundary & 0.1 & 0.0 & 0.0 & 0.0 \\
\hline \multicolumn{5}{|l|}{ Specified flow } \\
\hline Pajarito boundary & 10.1 & 10.1 & 10.1 & 10.1 \\
\hline Sangre de Cristo bed & 20.9 & 20.9 & 20.9 & 20.9 \\
\hline South boundary & 0.6 & 0.6 & 0.6 & 0.6 \\
\hline Sewage recharge & 0.0 & 6.9 & 6.9 & 6.9 \\
\hline Santa Fe River & 7.5 & 2.2 & 2.2 & 2.2 \\
\hline Other boundaries & 10.1 & 10.1 & 10.1 & 10.1 \\
\hline Total specified flow & 49.2 & 50.8 & 50.8 & 50.8 \\
\hline Areal recharge & 4.8 & 4.8 & 4.8 & 4.8 \\
\hline Head dependent (rivers) & 1.3 & 1.3 & 1.3 & 1.3 \\
\hline Total inflow & 57.4 & 74.5 & 71.6 & 71.6 \\
\hline \multicolumn{5}{|l|}{ Outflow } \\
\hline Storage & 0.0 & -4.5 & -2.6 & -2.7 \\
\hline \multicolumn{5}{|l|}{ Constant head } \\
\hline North boundary & -3.8 & -3.7 & -3.7 & -3.7 \\
\hline Southwest boundary & -12.1 & -12.1 & -12.1 & -12.1 \\
\hline \multicolumn{5}{|l|}{ Specified flow } \\
\hline Los Alamos field & 0.0 & -0.1 & 0.0 & 0.0 \\
\hline Guaje field & 0.0 & -2.0 & -1.6 & 0.0 \\
\hline Pajarito-Otowi field & 0.0 & -4.4 & -4.8 & -6.4 \\
\hline Buckman field & 0.0 & -3.3 & -3.3 & -3.3 \\
\hline Santa Fe field & 0.0 & -2.9 & -2.3 & -2.3 \\
\hline Private wells & 0.0 & -1.5 & -1.5 & -1.5 \\
\hline South boundary & -2.3 & -2.3 & -2.3 & -2.3 \\
\hline Other boundaries & -6.5 & -6.5 & -6.5 & -6.5 \\
\hline Total specified flow & -8.8 & -23.0 & -22.3 & -22.3 \\
\hline Head dependent (rivers) & -32.7 & -31.3 & -31.0 & -30.9 \\
\hline Total outflow & -57.4 & -74.6 & -71.6 & -71.7 \\
\hline
\end{tabular}


Table 3.--Model budget items that change with time [All flows in cubic feet per second; apparent discrepancies in the tenths place are caused by rounding]

\begin{tabular}{|c|c|c|c|c|c|c|}
\hline & $\begin{array}{l}\text { Steady } \\
\text { state }\end{array}$ & $\begin{array}{c}\text { Stress } \\
\text { period } 46 \\
\text { (1993) }\end{array}$ & $\begin{array}{l}\text { Change } \\
\text { from } \\
\text { steady } \\
\text { state to } \\
\text { stress } \\
\text { period } 46\end{array}$ & $\begin{array}{c}\text { Stress } \\
\text { period } 47 \\
\text { (2013) } \\
\text { Guaje } \\
\text { alterna- } \\
\text { tive }\end{array}$ & $\begin{array}{c}\text { Stress } \\
\text { period } 47 \\
\text { (2013) } \\
\text { Pajarito } \\
\text { - Otowi } \\
\text { alterna- } \\
\text { tive }\end{array}$ & $\begin{array}{c}\text { Change } \\
\text { from } \\
\text { Guaje to } \\
\text { Pajarito } \\
\text {-Otowi } \\
\text { alterna- } \\
\text { tive }\end{array}$ \\
\hline $\begin{array}{l}\text { Storage (net) } \\
\text { Constant head }\end{array}$ & 0.0 & 11.1 & 11.1 & 10.0 & 10.0 & 0.0 \\
\hline North boundary (net) & -1.9 & -1.7 & 0.2 & -1.7 & -1.7 & -0.0 \\
\hline Southwest boundary (net) & -12.1 & -12.1 & 0.0 & -12.0 & -12.0 & 0.0 \\
\hline South boundary & 0.1 & 0.0 & -0.1 & 0.0 & 0.0 & 0.0 \\
\hline \multicolumn{7}{|l|}{ Specified flow } \\
\hline Santa Fe River recharge & 7.5 & 9.1 & 1.6 & 9.1 & 9.1 & 0.0 \\
\hline Los Alamos field & 0.0 & -0.1 & -0.1 & 0.0 & 0.0 & 0.0 \\
\hline Guaje field & 0.0 & -2.0 & -2.0 & -1.6 & 0.0 & 1.6 \\
\hline Pajarito-Otowi field & 0.0 & -4.4 & -4.4 & -4.8 & -6.4 & 1.6 \\
\hline Buckman field & 0.0 & -3.3 & -3.3 & -3.3 & -3.3 & 0.0 \\
\hline Santa Fe field & 0.0 & -2.9 & -2.9 & -2.3 & $-2 \cdot 3$ & 0.0 \\
\hline Private wells & 0.0 & -1.5 & -1.5 & -1.5 & -1.5 & 0.0 \\
\hline $\begin{array}{l}\text { Total withdrawals } \\
\text { from wells }\end{array}$ & 0.0 & -14.2 & -14.2 & -13.5 & -13.5 & -0.0 \\
\hline Areal recharge & 4.8 & 4.8 & 0.0 & 4.8 & 4.8 & 0.0 \\
\hline $\begin{array}{l}\text { Head dependent } \\
\text { (xivers, net) }\end{array}$ & $-31 \cdot 3$ & -29.9 & 1.4 & -29.6 & -29.6 & 0.0 \\
\hline
\end{tabular}

The third column of numbers in table 3 shows the change from steady state to stress period 46 flows. The specified 14.2 cubic feet per second withdrawn from wells is made up mainly by a simulated 11.1 cubic feet per second from storage, 1.6 cubic feet per second additional recharge along the Santa Fe River, and 1.4 cubic feet per second capture from rivers. The effects of individual wells or well fields is not indicated.

A comparison of the budget (table 2) with that of McAda and Wasiolek (1988, p. 36) reveals that the total budget for steady-state conditions is 16.4 cubic feet per second less than that of McAda and Wasiolek. Most of the difference is in the Pajarito boundary, which is 8.5 cubic feet per second less, and areal recharge, which is 5.8 cubic feet less than that of McAda and Wasiolek. These smaller flow values are consistent with smaller values of hydraulic conductivity. 


\section{Model Adjustments}

The general goal of model adjustment was to make model-derived values of hydraulic head and streamflow match measured values while keeping the simulated system properties reasonable in view of the foregoing discussion of geohydrology. Simulated system properties that were adjusted were recharge, hydraulic conductivity, specific yield, and storage.

\section{System Properties Used for Comparison}

Measured hydraulic heads and estimated streamflow gains were used for comparison with model-derived values. The objective of model adjustment was to minimize the average difference between measured and model-derived hydraulic heads and especially to match model-derived fluctuations in hydraulic head with measured fluctuations, as explained in the following discussion.

The gain in flow of the Rio Grande between Otowi and Cochiti may be between 10 and 30 cubic feet per second on the basis of various estimates. A model-derived value was 13 cubic feet per second under steady-state conditions for the upper three-fourths of the reach from Otowi Bridge to Cochiti Pueblo, which is within the modeled area.

Measured hydraulic heads were divided into several groups. One group of hydraulic heads comprised those values that McAda and Wasiolek (1988) considered to be approximately representative of predevelopment (assumed to be steady-state) conditions plus eight additional values also considered to represent predevelopment conditions. Of these 184 hydraulic heads 2 represented layer 2, 8 represented layer 3, and 7 represented layer 4; the remainder represented layer 1 . The mean difference between these 184 measured hydraulic heads and steady-state model-derived values was 16 feet, and the standard deviation of these differences was 67 feet. These statistics may be compared with those of McAda and Wasiolek (1988, p. 35) for 176 measured hydraulic heads with a mean difference of 17.2 feet and standard deviation of 57.5 feet.

A second group of hydraulic heads comprised 53 values measured during November 1976 to April 1977 and was considered to represent the water table at the beginning of 1977; a third group comprised 60 values measured during November 1992 to April 1993 and was considered to represent the water table at the beginning of 1993. The 1977 and 1993 groups were plotted on maps for comparison with model-derived potentiometric surfaces (contours) for layer 1 . The model-derived potentiometric surface for the 1977 transient-state simulation is shown in figure 15; the map for 1993 (fig. 16) is similar except in the well fields. These groups were also used in statistical comparisons (table 13 in supplemental information).

Of a total of 297 hydraulic-head values representing steady state, 1977, and 1993, the arithmetic mean difference between measured and model-derived hydraulic heads was 11.7 feet. This indicates that the differences were more positive than negative, or that the model-derived potentiometric surfaces generally were higher than those measured. The mean of the absolute values of the differences was 53.4 feet. As explained by McAda and Wasiolek (1988, p. 35), the differences between measured and model-derived hydraulic heads result from the inability of the model to represent the details of aquifer variability in the area. Also, the measured hydraulic head, representing a composite over the entire screened interval of a well at a given location, may not represent the point coinciding with the center of the three-dimensional model cell. Because gradients are 50 to 100 feet per mile, it may be unrealistic to expect a much better match of model-derived to measured hydraulic heads. Model evaluation is discussed in a following section. 


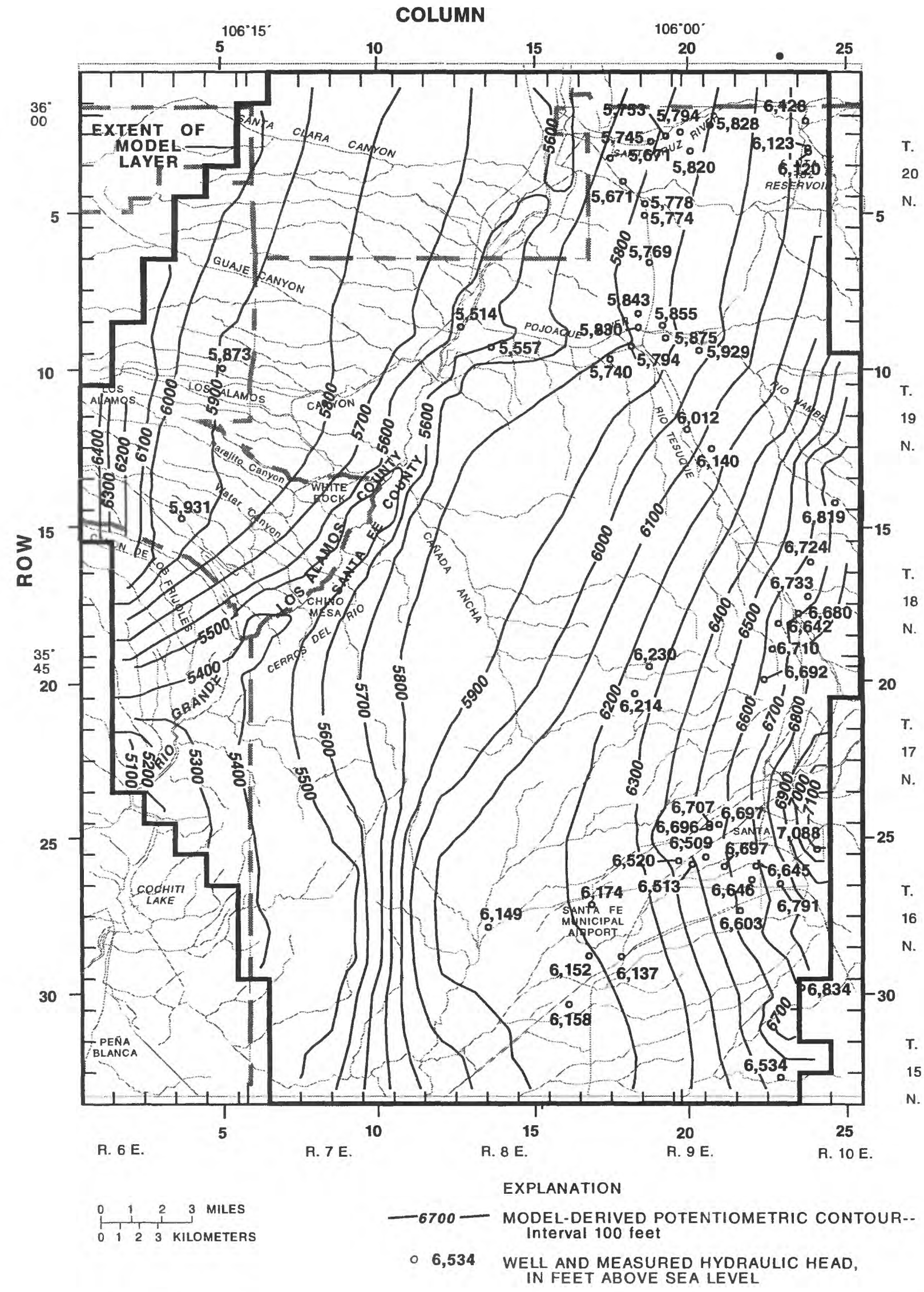

Figure 15.--Model-derived potentiometric surface for layer 1 and measured hydraulic heads for 1977. 


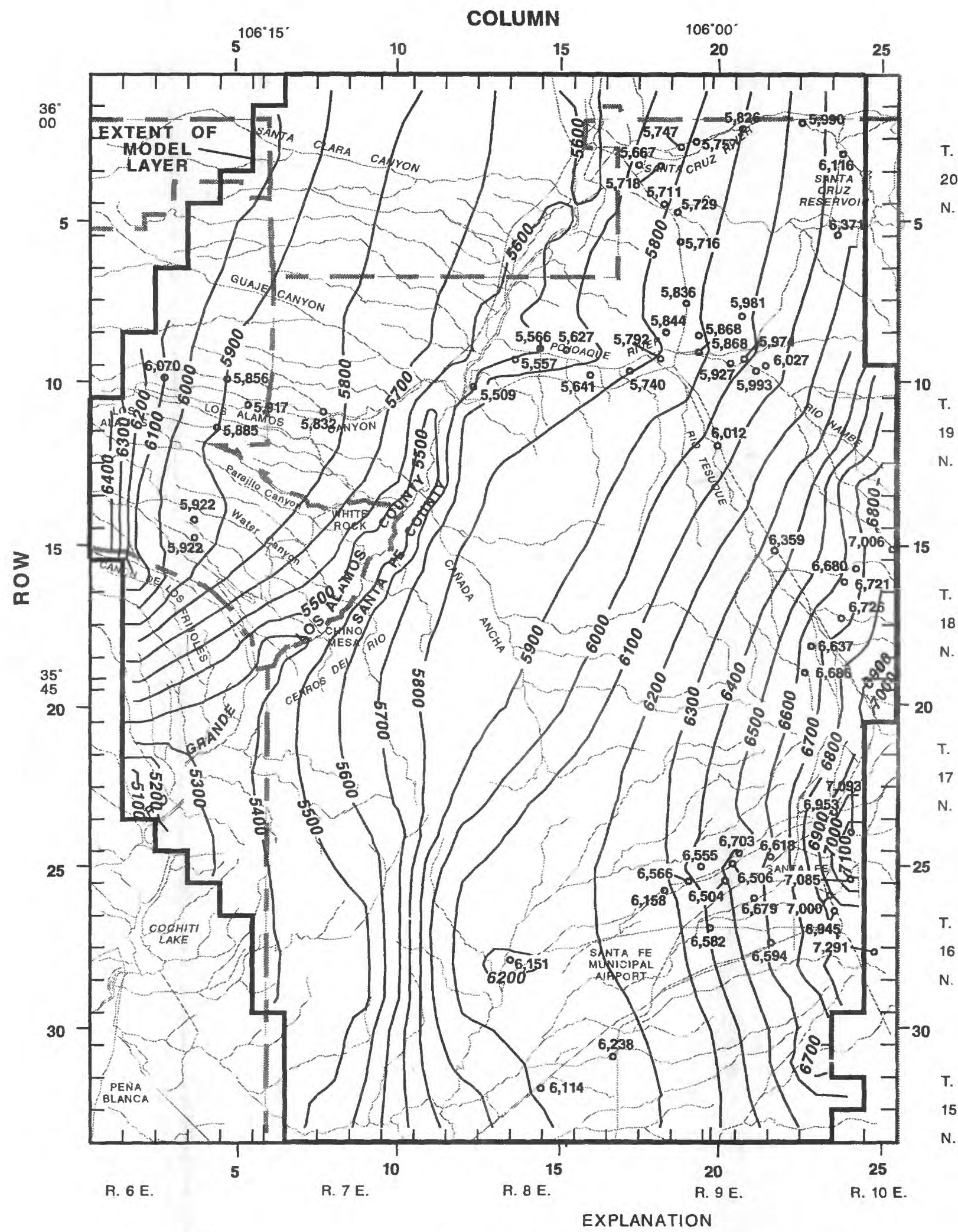

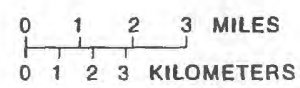

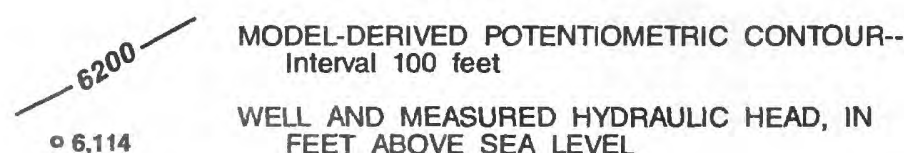

Figure 16.--Model-derived potentiometric surface for layer 1 and measured hydraulic heads for 1993. 
A fourth group of hydraulic heads comprised a history of measured hydraulic heads at specific wells. Hydraulic heads in this group were plotted as hydrographs for comparison with model-derived hydrographs. Many of the wells having hydrographs are production wells, completed over intervals that span two or more layers. In this case, comparison is made to the layer that represents the middle of the completed interval. Only nonpumping water levels were used to construct the hydrographs. Matching the hydrographs was the first priority during model adjustments. Locations of wells having hydrographs are shown in figure 17. The main objective of hydrograph comparison was to match annual and longer term fluctuations. A secondary objective was to match the absolute value of hydraulic heads, although, as previously explained, this could be difficult because the model-derived values are for cell centers, not for exact well locations.

Hydrographs shown in figures 18-22 feature two main curves. The solid curve shows the model-derived hydraulic heads. The dashed curve is the same as the solid curve except that it is offset vertically to pass through the first measured hydraulic head. In some cases, the dashed curve helps to assess the comparison between measured and model-derived fluctuations. The measured hydraulic heads are shown as circles. Model-derived hydraulic heads are projected after 1993. In each hydrograph, the main curve continues through 2013 using the Guaje alternative. A branch off the main curve was projected using the Pajarito-Otowi alternative. The alternatives and projections are explained and discussed in a subsequent section of this report.

Wells in the Los Alamos well field are shown in figure 18A-G, proceeding from east to west. Model-derived curves generally are higher than measured values. The fluctuations of the modelderived curves generally match the measured values, which tend to be similar for the entire field, and probably are a manifestation of overlapping cones of depression in the area. The fluctuations of the same model-derived curve (layer 3, row 10, column 11) better match the measured values at LA-2 (fig. 18C) than at LA-3 (fig. 18D), indicating that some features of the hydrologic system are not well represented by the model at the location of LA-3.

Wells in the Guaje well field are shown in figure 19A-G, again proceeding from east to west. The model-derived curves tend to be higher than the measured values for the east end of the field and lower for the west end. A recovery of hydraulic heads during the late 1960 's is not as apparent in the measured values for wells G-1, G-1A, G-2, and G-5 (fig. 19A-C, and F) as in the model-derived curves. The hydraulic-head recovery during the late 1960's is apparent in measured and simulated values for well G-6 (fig. 19G), again indicating that some local features of the hydrologic system are not well represented at the locations of G-1, G1A, G-2, and G-5. Otherwise, the fluctuations of the model-derived curves well match the measured values.

Test and production wells in the vicinity of the Pajarito Mesa well field are positioned on facing pages in figure 20 approximately in their relative field locations: hydrographs for northern wells are at the top of the pages. Test wells are designated by LANL with the letters TW or DT, and Pajarito Mesa production wells are designated with the letters PM. The modelderived curves are higher than measured values on the northeast at wells TW-1 and PM-1 (fig. 20D and H), but lower at neighboring wells TW-3 and PM-3 (fig. 20C and G). Conversely, the model-derived curve is lower than measured values at well TW-4 and higher at neighboring wells. A partial explanation is that well TW-4 is located on a relatively steep gradient upslope from the center of the model cell. The relatively gentle declines of the model-derived curves well match the measured values for about half of the wells. At well TW-1 (fig. 20D) the markedly higher hydraulic heads measured in the 1990's may reflect very local conditions at the site (Environmental Protection Group, 1993, p. VII-22). Also, at well PM-1 (fig. 20H) early measured hydraulic heads are considered to represent a time of partial well development (Alan Stoker, Los Alamos National Laboratory, Environmental Protection Group, oral commun., 1993). 


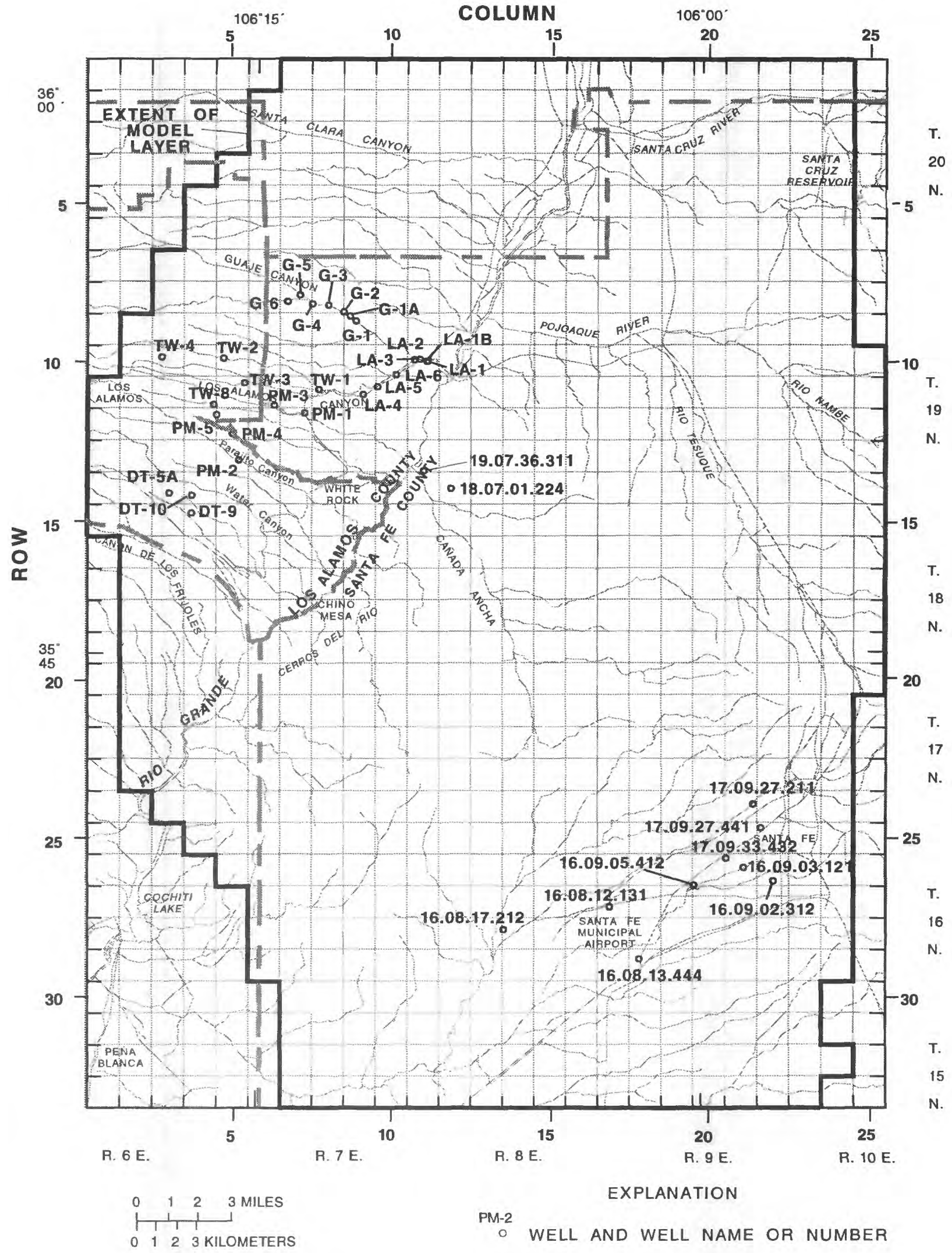

Figure 17.--Location of wells having hydrographs. 
A $210113553011060922 \quad$ LA-1
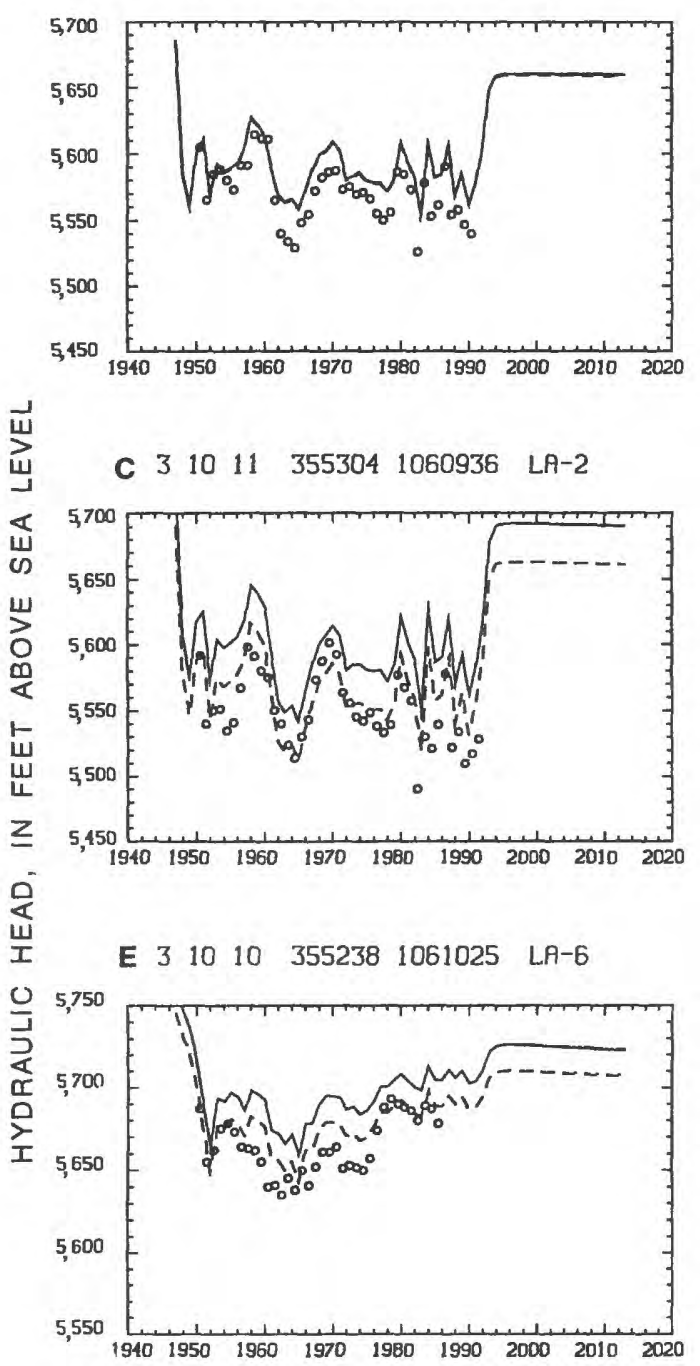

\section{G $411 \quad 9 \quad 355205 \quad 1061131 \quad$ LA-4}

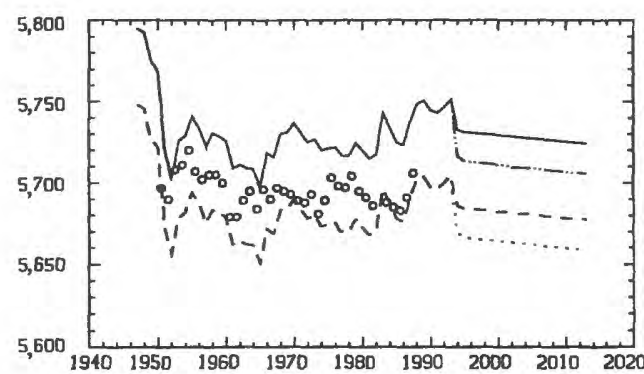

B $410113553011060920 \quad$ LA-1B

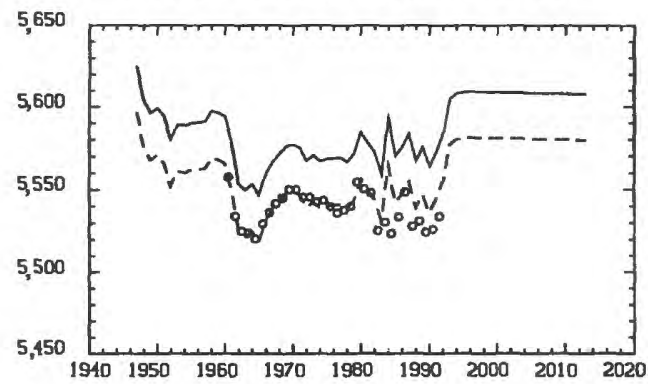

D $310113553031060947 \quad$ LA-3

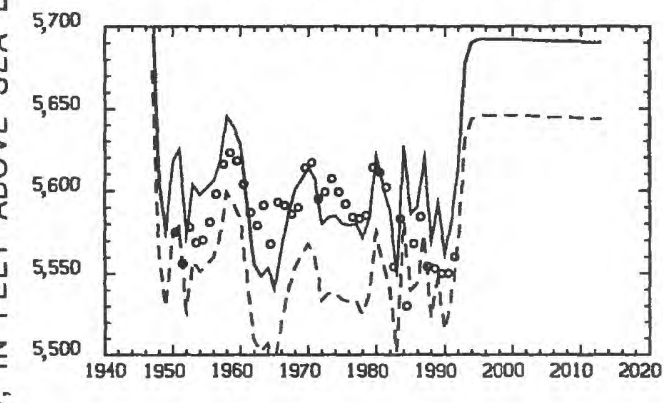

崖

F $41110355218 \quad 1061102$ LP-5

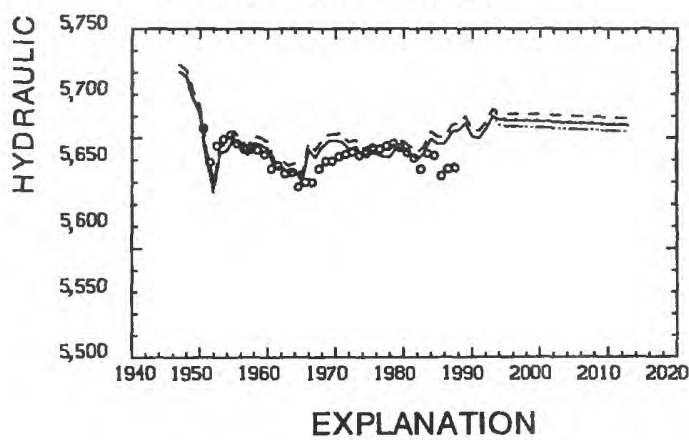

EXPLANATION

LAYER ROW COLUMN LATITUDE LONGITUDE LOCAL WELL NUMBER

$\begin{array}{llll}411 & 9 & 355205 & 1061131 \quad \text { LA-4 }\end{array}$ MODEL-DERIVED HYDROGRAPH USING GUAJE ALTERNATIVE AFTER 1992

MODEL-DERIVED HYDROGRAPH USING PAJARITO-OTOWI ALTERNATIVE AFTER 1992

MODEL-DERIVED HYDROGRAPH USING GUAJE ALTERNATIVE AFTER 1992--Offset to pass through first measured hydraulic head

MODEL-DERIVED HYDROGRAPH USING PAJARITO-OTOWI ALTERNATIVE AFTER 1992-Offset to pass through first measured hydraulic head

MEASURED HYDRAULIC HEAD

Figure 18.--Hydrographs for wells in the Los Alamos well field, north-central New Mexico (location of wells shown in fig. 17). 
A $\quad 4 \quad 9 \quad 9 \quad 355407 \quad 1061146 \quad$ G-1

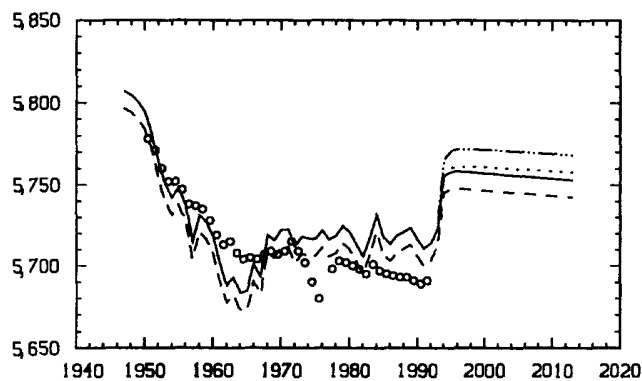

$\begin{array}{llllllll}\text { C } & 3 & 8 & 8 & 355422 & 1061210 & \text { G-2 }\end{array}$
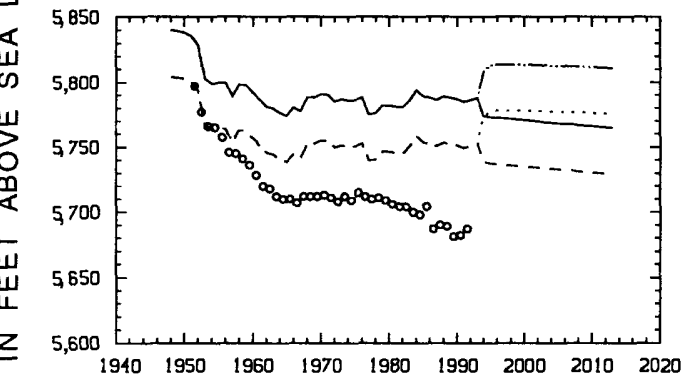

迹

E $\quad \begin{array}{lllllll}3 & 8 & 7 & 355435 & 1061314 & \text { G-4 }\end{array}$

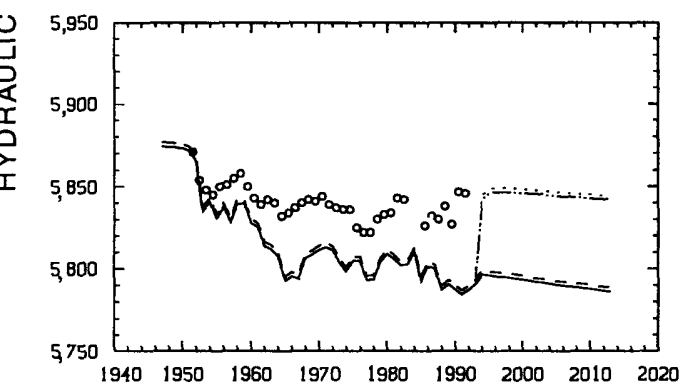

$\begin{array}{lllllll}3 & 8 & 7 & 355439 & 1061404 & G-6\end{array}$

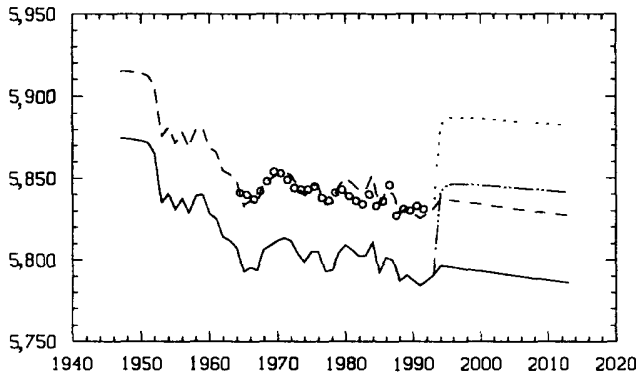

B $\quad 3 \quad 3 \quad 9 \quad 9 \quad 355415 \quad 1061158 \quad$ G-1A
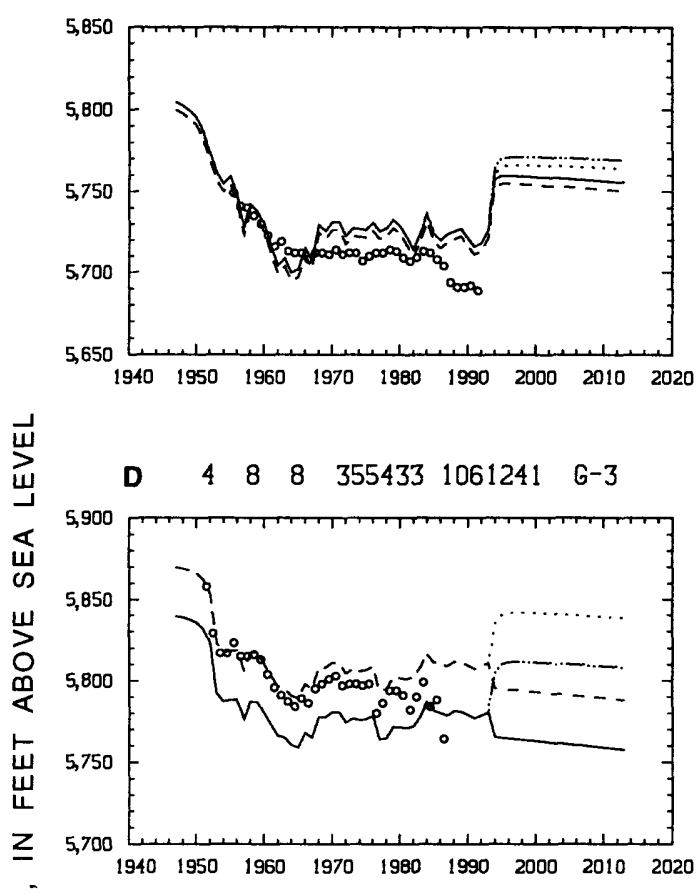

这

$\begin{array}{llllllll}\text { F } & 3 & 8 & 7 & 355450 & 1061339 & \text { G-5 }\end{array}$

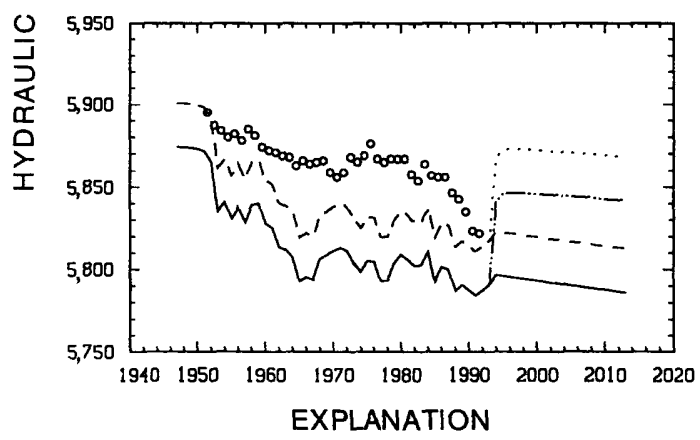

LAYER

$1 /$ ROW COLUMN LATITUDE LONGITUDE LOCAL WELL NUMBER

$\begin{array}{lllll}387 & 7554501061339 & \text { G-5 }\end{array}$

MODEL-DERIVED HYDROGRAPH USING GUAJE ALTERNATIVE AFTER 1992

MODEL-DERIVED HYDROGRAPH USING PAJARITO-OTOWI ALTERNATIVE AFTER 1992

MODEL-DERIVED HYDROGRAPH USING GUAJE ALTERNATIVE AFTER 1992---Offset to pass through first measured hydraulic head

MODEL-DERIVED HYDROGRAPH USING PAJARITO-OTOWI ALTERNATIVE AFTER 1992--Offset to pass through first measured hydraulic head

MEASURED HYDRAULIC HEAD

Figure 19.--Hydrographs for wells in the Guaje well field, north-central New Mexico (location of wells shown in fig. 17). 
A $1 \quad 10 \quad 3 \quad 355307 \quad 1061817 \quad$ TW-4

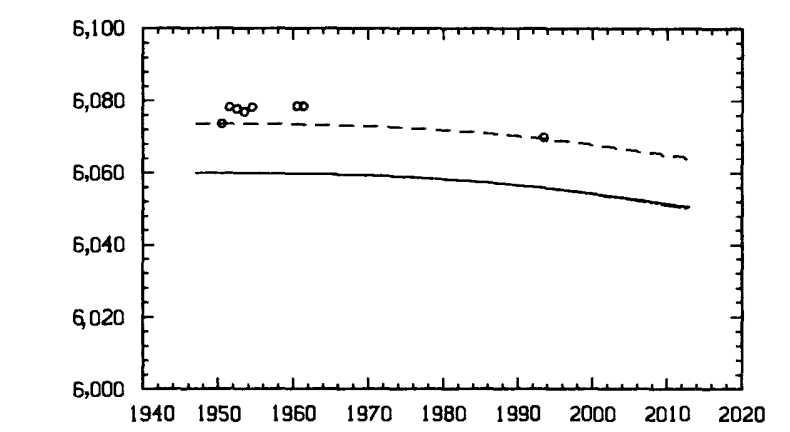

E 1111443551481061633 TW-8

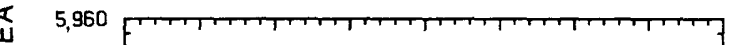

W

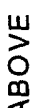

w

ш

$\underline{z}$

岸

$\frac{0}{2}$

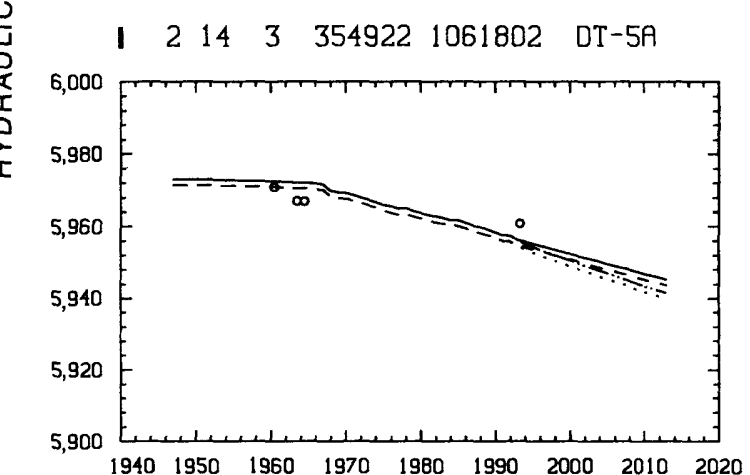

B $1110 \quad 5 \quad 3553051061613 \quad$ TW-2
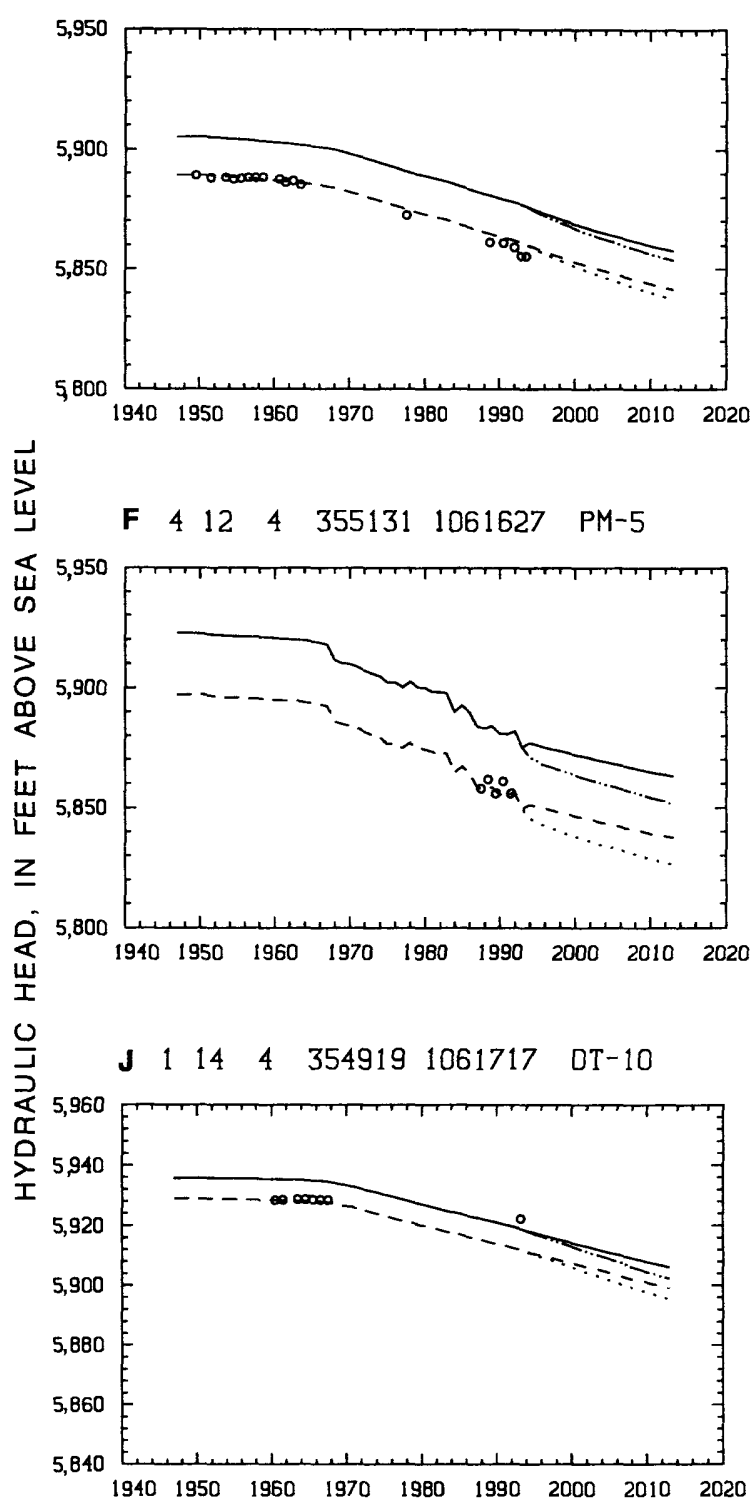

$\begin{array}{llllllll}\text { L } & 1 & 15 & 4 & 354850 & 1061717 & \mathrm{DT}-9\end{array}$

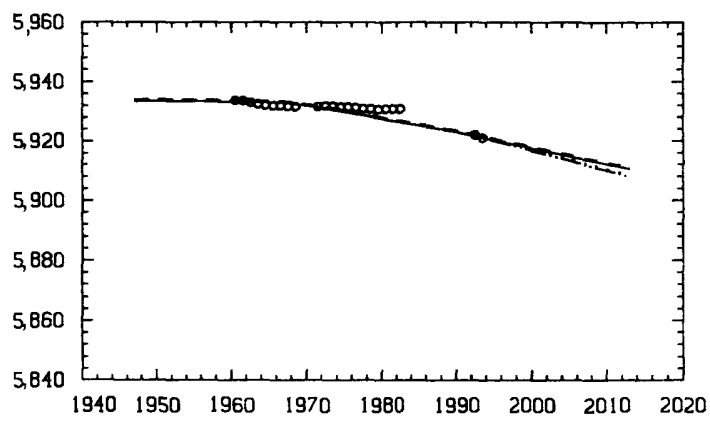

Figure 20.--Hydrographs for wells in the Pajarito Mesa well field, north-central New Mexico (location of wells shown in fig. 17). 
C $1111 \quad 5 \quad 3552241061531 \quad \mathrm{TW}-3$

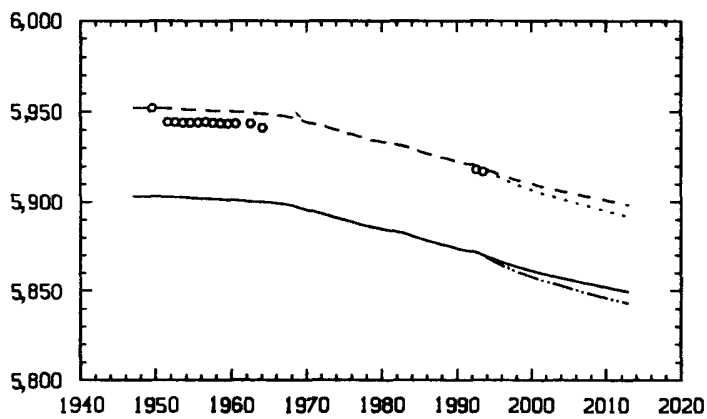

G $4 \begin{array}{llllll}11 & 6 & 355147 & 1061431 & \text { PM-3 }\end{array}$

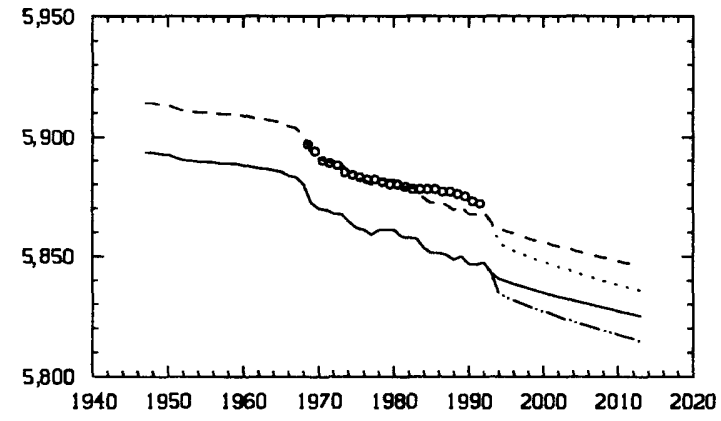

K $41253550601061555 \quad \mathrm{PM}-4$

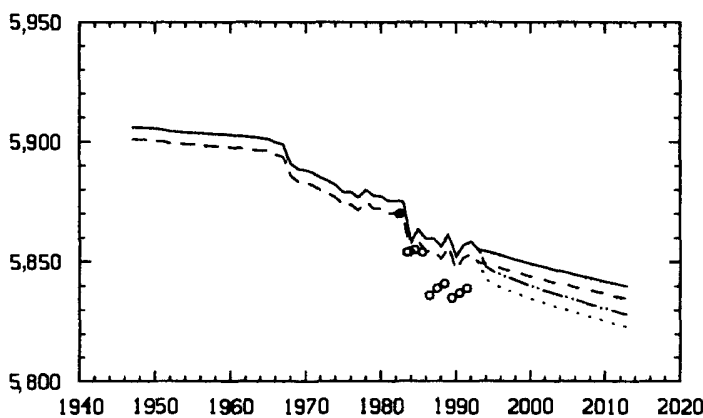

M $4 \quad 13 \quad 5 \quad 355017 \quad 1061542 \quad P M-2$

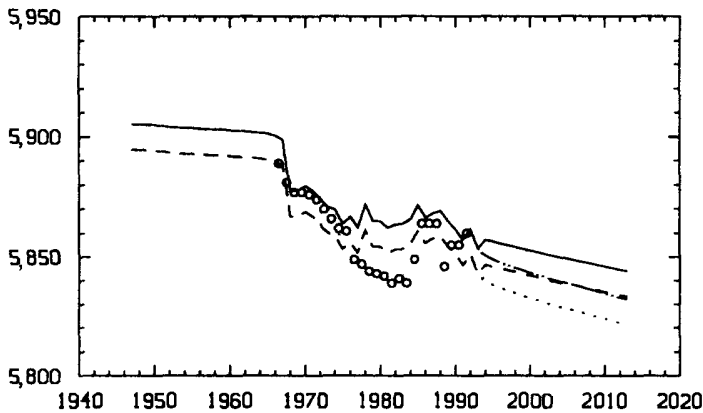

D $111180355213 \quad 1061301 \quad$ TW-1

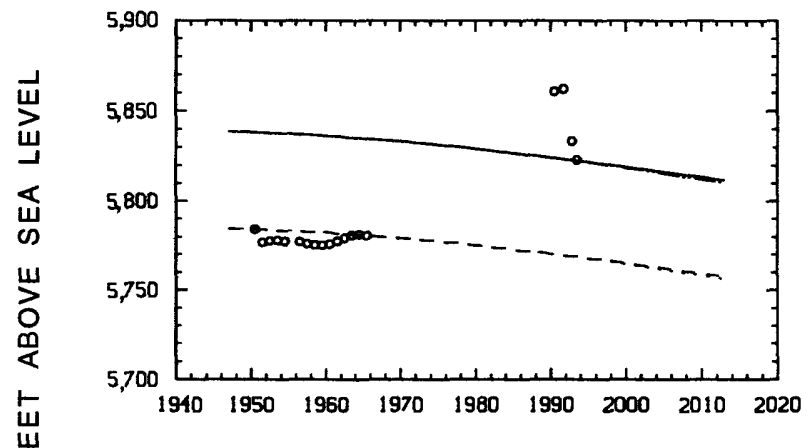

H $4 \begin{array}{llllll}4 & 12 & 7 & 355134 & 1061329 & P M-1\end{array}$

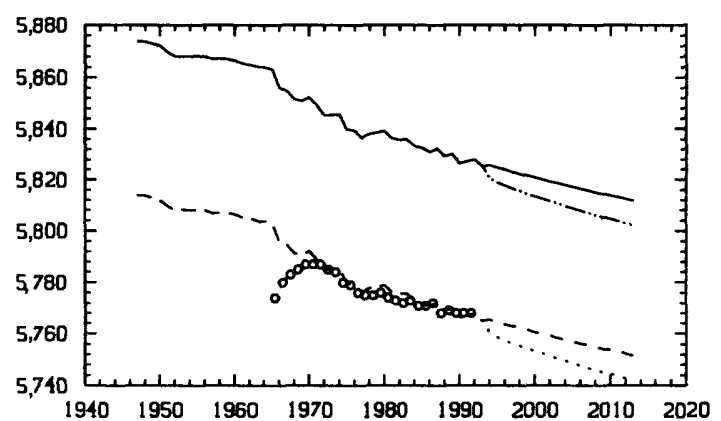

EXPLANATION

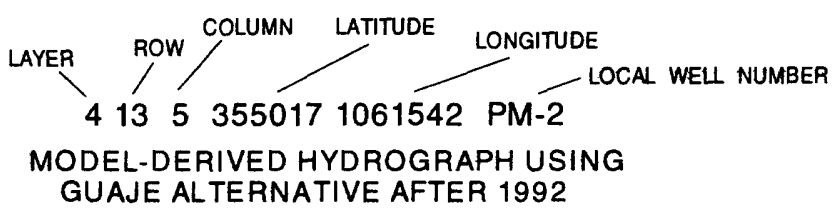

MODEL-DERIVED HYDROGRAPH USING PAJARITOOTOWI ALTERNATIVE AFTER 1992

MODEL-DERIVED HYDROGRAPH USING GUAJE ALTERNATIVE AFTER 1992--Offset to pass through first measured hydraulic head

MODEL-DERIVED HYDROGRAPH USING PAJARITO-OTOWI ALTERNATIVE AFTER 1992-Offset to pass through first measured hydraulic head

MEASURED HYDRAULIC HEAD

Figure 20.--Hydrographs for wells in the Pajarito Mesa well field, north-central New Mexico (location of wells shown in fig. 17)--Concluded. 

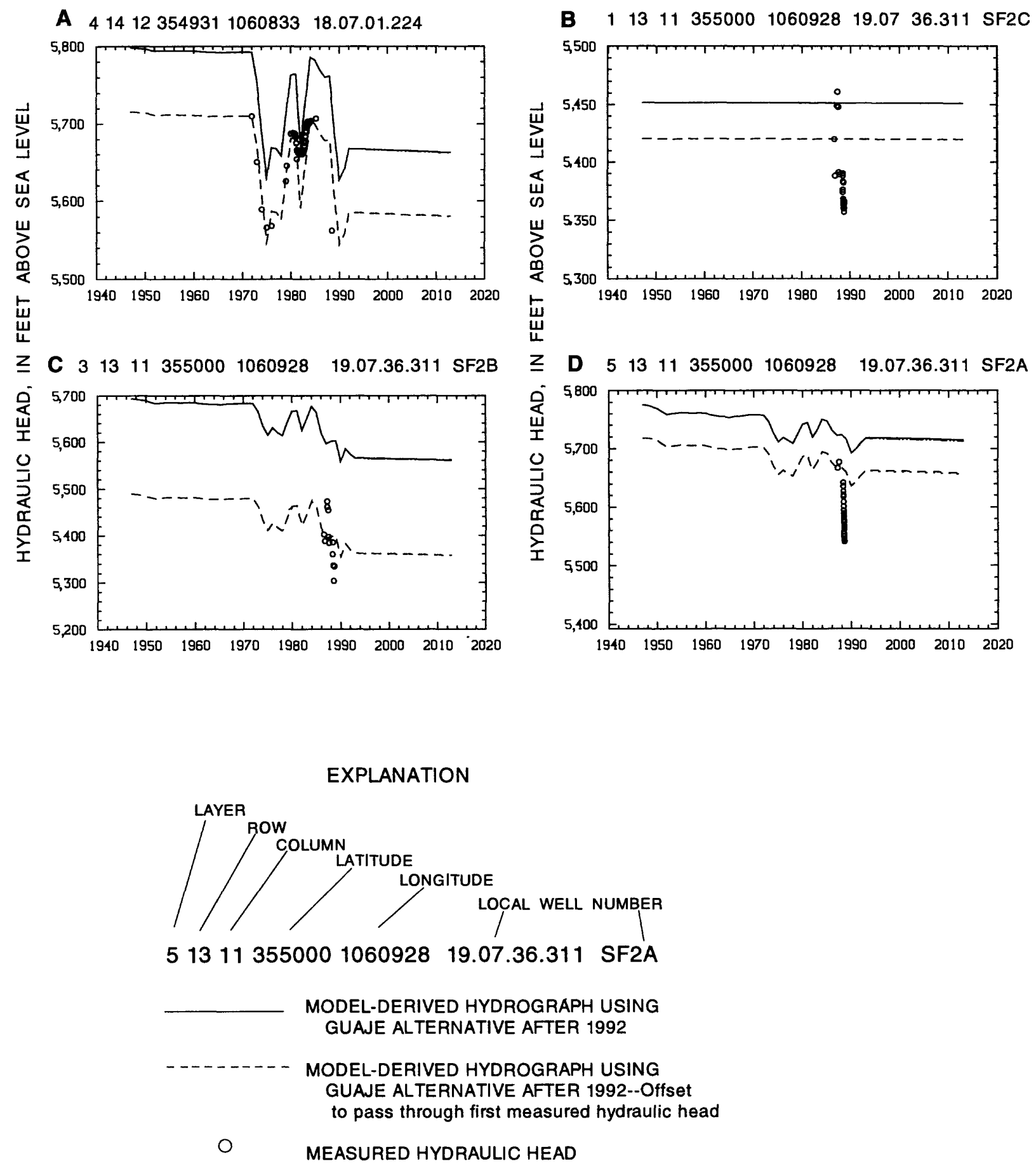

Figure 21.--Hydrographs for wells in the Buckman well field, north-central New Mexico (location of wells shown in fig. 17). 
A $12422 \quad 3540521055821 \quad 17.09 .27 .211$

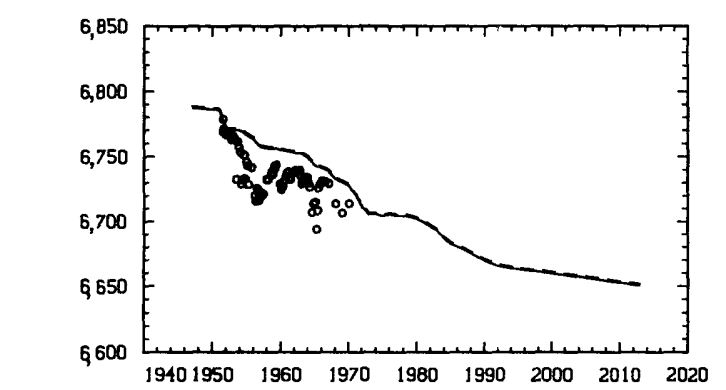

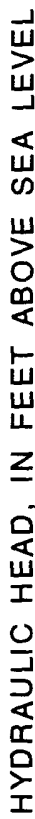

$\begin{array}{llllll}\text { C } 12620 & 353923 & 1055915 & 17.09 .33 .432\end{array}$

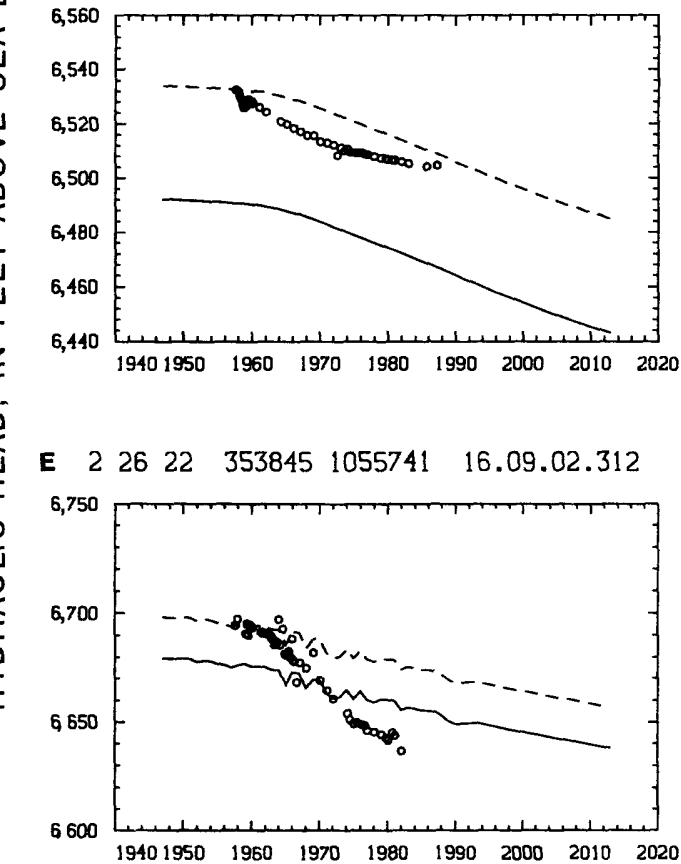

B $32522 \quad 354013 \quad 1055806 \quad 17.09 .27 .441$

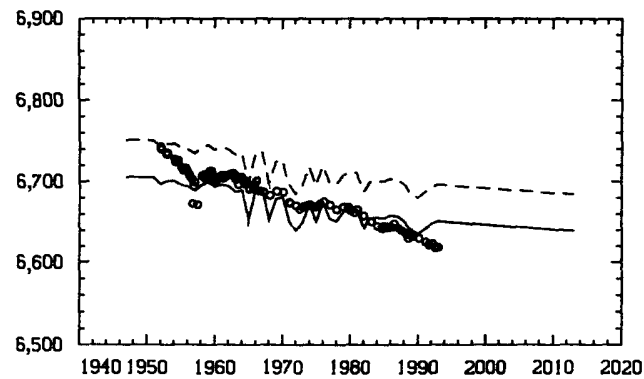

$\vec{w}$

$\begin{array}{lllllll}\text { D } 12621353907 & 1055837 & 16.09 .03 .121 & \text { A8B }\end{array}$

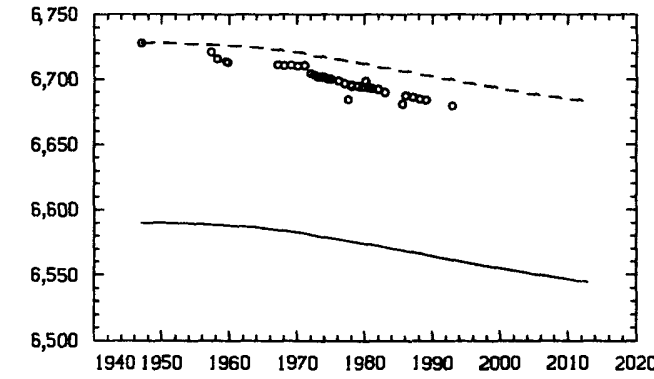

운

$\begin{array}{llllllll}\text { W } & 1 & 27 & 17 & 353803 & 1060310 & 16.08 .12 .131\end{array}$

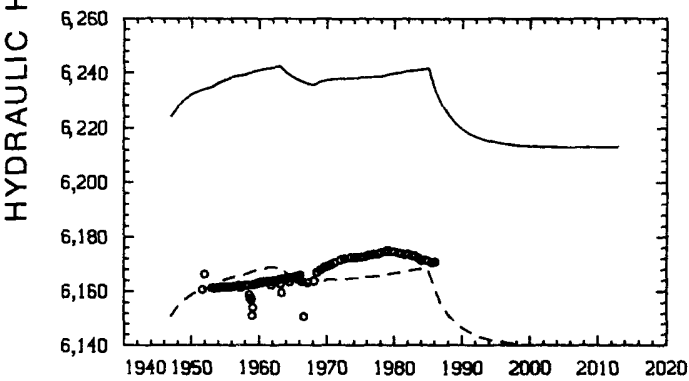

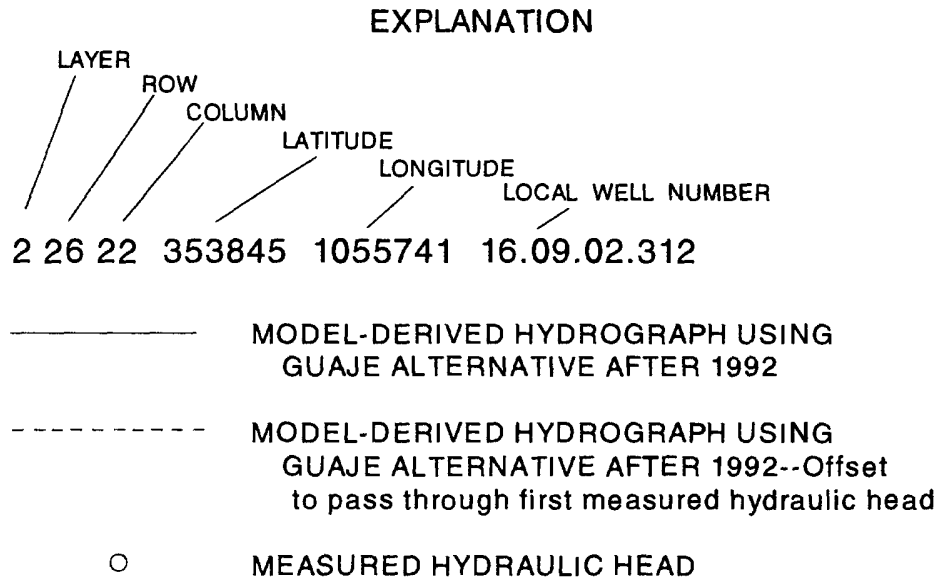

Figure 22.--Hydrographs for wells in the Santa Fe area, north-central New Mexico (location of wells shown in fig. 17). 

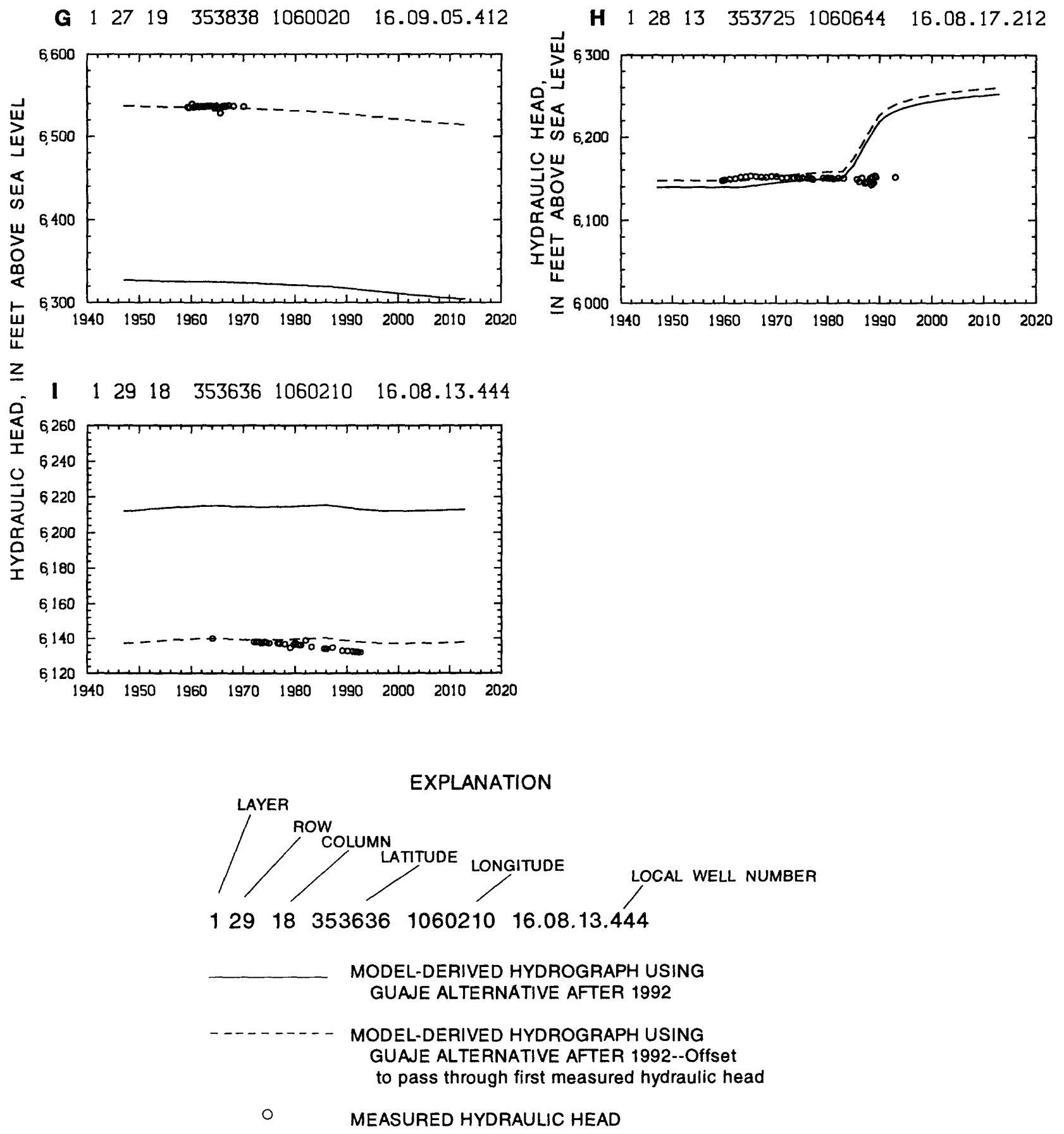

Figure 22.--Hydrographs for wells in the Santa Fe area, north-central New Mexico (location of wells shown in fig. 17)--Concluded. 
Fluctuations in model-derived curves do not match fluctuations in measured values during the late 1970's and early 1980's at wells PM-4 and PM-2 (fig. 20K and M), although the overall slope of the curve at PM-2 matches well. Model-derived curves decline more quickly than seen in the general trend of measured values at wells DT-5A and DT-10 (fig. 20I and J), located southwest of the field, but the slope of the model-derived curve well matches the trend of measured values at well DT-9.

Hydrographs for four wells in the Buckman well field are shown in figure 21. Modelderived curves appear to be generally higher than measured values. Because most of the wells in the Buckman field flowed, however, initial hydraulic heads are not known. Model-derived fluctuations match measured fluctuations for well 18.07.01.224 (fig. 21A). Although this is not the case for the other three wells, the limited duration of the record makes the comparison difficult to evaluate. One possible explanation for the lack of an abrupt decline in the model-derived curve to match that evident in the measured values could be that ground-water withdrawals for 1988 were largely from well B-1, near the observation well nest, but were assigned to the entire well field (as previously described). The effect of incorrectly assigning withdrawals within the Buckman field would be that the simulated potentiometric surface within the Buckman field would be different than might have been observed; however, the effect beyond the Buckman field should not be great.

Hydrographs for wells in the Santa Fe area are shown in figure 22. The model-derived curves match the measured values about as well as those of McAda and Wasiolek (1988, fig. 20). An exception is the model-derived curve for well 16.08.17.212 (fig. $22 \mathrm{H}$ ), which diverges sharply from the measured values starting in 1983. Similarly, the model-derived curve for well 16.08.12.131 (fig. 22F) has a precipitous drop, whereas the short record of measured values does not drop. This probably indicates that the model representation of sewer-plant effluent recharge is incorrect. Because these mismatches seem to be limited to the localities of wells not in the area of interest for this study, data necessary to make corrections were not collected.

\section{System Properties Adjusted}

Properties adjusted were recharge, mainly along the Pajarito Fault Zone; hydraulic conductivity near Los Alamos; and specific yield and storage. Hydraulic conductivity was the primary focus of adjustment.

\section{Recharge}

Recharge along the Pajarito Fault Zone was adjusted by changing the constant-head values specified in the steady-state simulation that was used to generate values for specified flows in subsequent steady-state and transient simulations. Although specified head values were increased from those specified by McAda and Wasiolek (1988) by an average of 141 feet in rows $7-18$, columns 1 and 2, the resultant specified recharge in rows 2-20 along the Pajarito Fault Zone of 10 cubic feet per second was less than the McAda and Wasiolek value of 19 cubic feet per second. The lesser flow rate results from hydraulic-conductivity values smaller than those of McAda and Wasiolek in much of the area except in the Pajarito Mesa well field.

Recharge along the Pajarito Fault Zone was simulated only in layer 1 . This is consistent with recharge occurring locally as indicated by the altitude of recharge previously discussed. If recharge were to occur at some distance from the fault zone, it might enter the modeled area at some depth. This possibility is addressed in the sensitivity analysis. 
Model-derived hydraulic heads were higher in the north-central part of the eight-layer model than in the four-layer model. As a partial correction for this, recharge in the northern part of the model was decreased on the basis of the zero recharge estimate of Anderholm (1994).

\section{Hydraulic conductivity near Los Alamos}

Hydraulic-conductivity values in the northwestern part of the model were adjusted to those shown in figures 11-12 to simulate measured hydraulic heads. Primarily the objective was to make model-derived hydrographs match measured hydraulic heads (figs. 18-22). In some cases, fluctuations in the model-derived curve well match fluctuations in the measured hydraulic heads, but the model-derived curve is too high (fig. 19B) or too low (fig. 20G), as indicated by the difference between the solid and dashed curves. The model-derived fluctuations at a site seemed to be controlled mainly by the hydraulic conductivity in the immediate vicinity. Whenever possible, the hydraulic conductivity was generalized to a wider area. For example, the hydraulicconductivity value for the Buckman well field, which is in the Tesuque Formation, seemed to work for the Tesuque in much of the northwestern part of the model, including the western part of the Los Alamos well field. However, at the east end of the Los Alamos well field, a smaller value of hydraulic conductivity was required to simulate the larger fluctuations there (fig. 18A-C) than in the western part of the field (fig. 18E-G).

The general configuration of the potentiometric surface (fig. 6) in the vicinity of the Pajarito Plateau was simulated under steady-state conditions (fig. 23) with higher hydraulic-conductivity values in the middle of the plateau than on the east or west sides of the plateau. This configuration of hydraulic conductivity results in a steeper potentiometric surface on the east and west sides of the plateau than in the middle. At first, the hydraulic conductivity representing the Chaquehui formation and Puye Formation was set at 10 feet per day in a strip from the Guaje well field on the north to the test wells south of the Pajarito Mesa well field (fig. 17). During adjustment, the values near the Guaje field (figs. 11-12) were decreased to simulate greater fluctuations in the hydrographs. Also, the eastward gradient across the Guaje field (figs. 2, 6, and 23) was more closely approximated by hydraulic-conductivity values in the Guaje field that were more nearly equal to those on the downgradient side. (As previously explained, steady-state conditions were assumed to represent predevelopment conditions that were assumed to have existed before 1947.) On the south end, the hydraulic conductivity representing the Chaquehui and Puye was reduced to slow the extension of drawdown cones into the area of test wells DT-5A, DT-9, and DT-10.

\section{Specific yield and storage}

Specific-yield and storage values were adjusted on a modelwide basis. Slight improvements in the simulation of some hydrographs were found to be balanced by poorer simulation of other hydrographs. Without a good geologic basis to specify storage values on a cell-by-cell basis, specific yield and storage were finally specified at approximately the same values as those of McAda and Wasiolek (1988). 


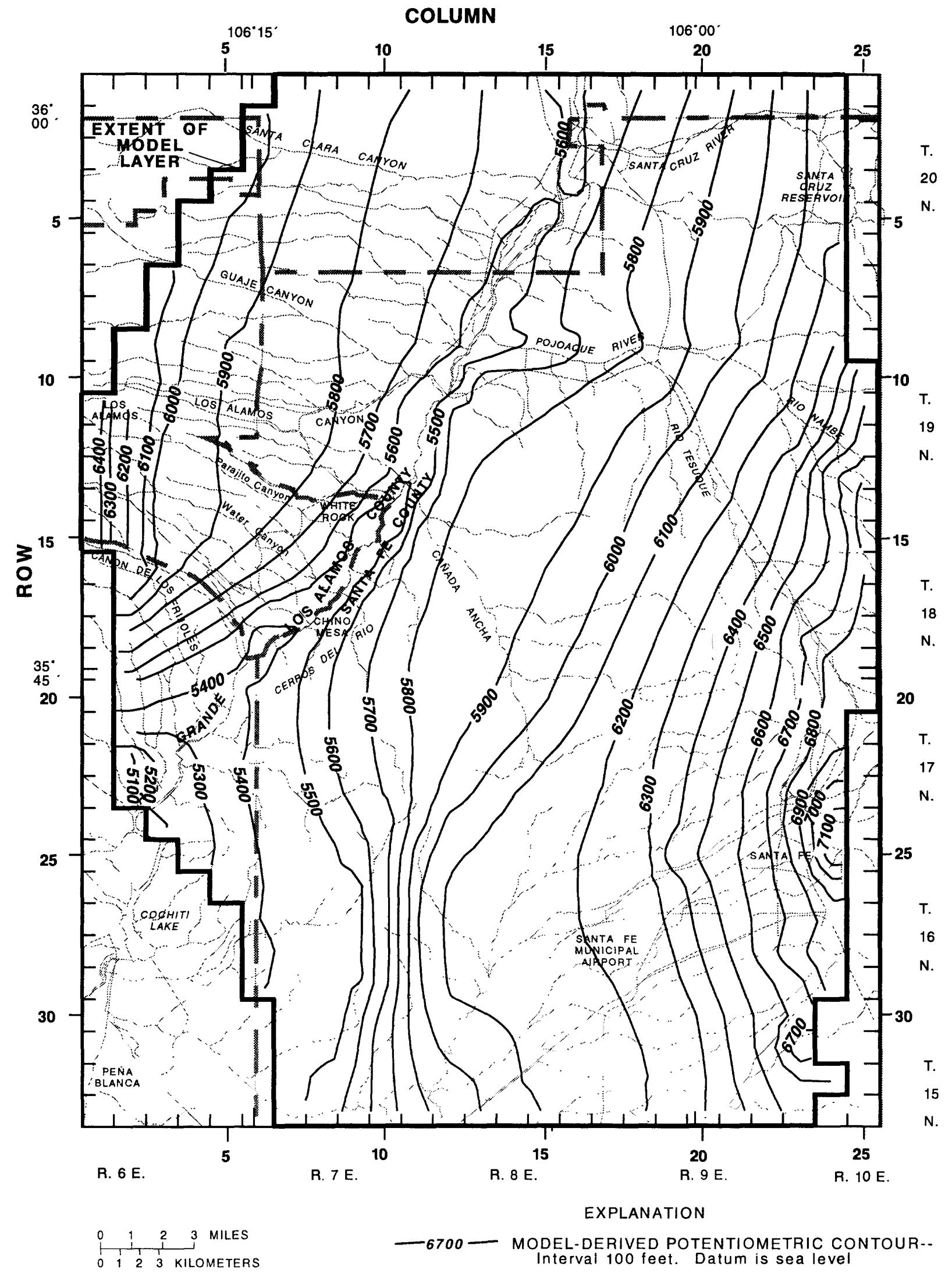

Figure 23.--Steady-state potentiometric surface for layer 1. 


\section{Simulated Response to Projected Withdrawals}

The main purpose of these simulations was to assess the effects of renewing the Guaje well field by replacing the six existing wells with four new wells in the same field (the "Guaje alternative") or of retiring the Guaje field and increasing withdrawals from other fields. The most likely alternative to withdrawing water from replacement wells in the Guaje field is increasing withdrawals from wells in the Pajarito Mesa and Otowi fields (the "Pajarito-Otowi alternative"). In either case, total production from LANL wells is assumed (Alan Stoker, written commun., Feb. $11,1994)$ to be 1.5 billion gallons per year.

The Guaje alternative is as follows:

-- 25 percent from the Guaje field, divided equally between each of four new wells;

-- 25 percent from the Otowi field, of which 25 percent is from well O- 1 and 75 percent from $\mathrm{O}-4$; and

-- 50 percent from the Pajarito Mesa field, divided in the same proportions as in 1992.

The Pajarito-Otowi alternative is as follows:

-- 33 percent from the Otowi field, of which 33 percent is from $0-1$ and 67 percent from $0-4$; and

-- 67 percent from the Pajarito Mesa field, divided in the same proportions as in 1992.

Two projections were made, one for each of the above-described alternatives. For the projections, one stress period with 20 equal 1-year time steps was added to the transient simulation. All ground-water withdrawals outside the LANL well fields were simulated at the 1992 rates as were other specified recharge/discharge rates. In figures 18-21, the model-derived hydrographs diverge after the beginning of 1993, reflecting the difference between the two alternatives. The solid line represents the Guaje alternative and the chain-dot line represents the Pajarito-Otowi alternative. As previously explained, the dashed line is the same as the solid line, offset vertically to pass through the first measured hydraulic head; the dotted line diverges from the dashed line as the chain-dot line diverges from the solid line. At wells near the eastern end of the Los Alamos well field (fig. 18A-E), no divergence between the two alternatives is visible at the scale shown. At the western end of the Los Alamos field (fig. 18G), projected hydraulic heads are about 20 feet higher with the Guaje alternative. This reflects the relative closeness of the Otowi and Pajarito Mesa fields to the LA-4 site. In the Guaje field (fig. 19), projected hydraulic heads are as much as 50 feet lower with the Guaje alternative, and in the Pajarito Mesa field (fig. 20), hydraulic heads are as much as 12 feet higher with the Guaje alternative, compared to the Pajarito-Otowi alternative. In the Buckman field (fig. 21), the divergence between the two alternatives is barely visible, and in the Santa Fe area (fig. 22), no divergence is visible at the scales shown. Although the difference between the two alternatives was not great at the scale shown in hydrographs for the Buckman field, projected hydraulic heads were 2 feet higher at layer 5, row 13, column 11 with the Guaje alternative because the Buckman field is closer to the Pajarito Mesa field than to the Guaje field.

Purtymun and Johansen (1974, fig. 3) showed a well site at a point about 4 miles north of the Guaje well field, although no records of wells in that vicinity are in the U.S. Geological Survey data base. At that point, located at model row 4, column 6, model-derived hydraulic heads for layer 1 were as follows:

5977.28 feet, under steady-state (initial) conditions;

5975.18 feet, for 1993;

5974.12 feet, for 2013 given the Pajarito-Otowi alternative; and

5973.63 feet, for 2013 given the Guaje alternative. 
Thus, the model-derived drawdown was about 2 feet by 1993 and an additional 1 foot by 2013 given the Pajarito-Otowi alternative. The Guaje alternative results in a model-derived drawdown of 0.5 foot more than the Pajarito-Otowi alternative at this location. The net flow (difference between inflow and outflow) to the head-dependent flow boundaries that represent the Rio Grande, Rio Pojoaque, and Rio Tesuque decreases through the transient simulation. During the part of the simulation that represents 1947-93, net flow decreases from 31.3 cubic feet per second under steady-state conditions to 29.9 cubic feet per second, a decrease of 1.4 cubic feet per second (table 3). During the 20-year projection, 1993-2013, simulated net flow to these streams declines an additional 0.3 cubic foot per second with both alternatives.

\section{$\underline{\text { Sensitivity Tests }}$}

The model is much simpler than the ground-water system that it represents. Therefore, any simulated responses of the ground-water system need to be used with caution. However, given its limited purpose, the model is considered to be adequate for making a preliminary projection of the effects of replacing the Guaje well field with new wells in approximately the same location. Although system properties used in the model are assumed to approximate those of the groundwater system, these properties are not known with certainty.

Sensitivity tests were used to assess the effects that the use of different values of system properties would have on: (1) the overall match between measured and model-derived hydraulic heads, (2) the model-derived hydrographs in each well field, and (3) the projected difference between the Guaje and Pajarito-Otowi alternatives. In each of the following tests, a system property was changed and the result compared with the unchanged model. For the purpose of comparison, the unchanged model described in previous sections of this report is termed the "standard" model, and in this discussion, all hydrographs and hydraulic heads are model derived unless specified as measured. All tests included running a steady-state reinitialization except those involving only storage values.

The overall match between measured and model-derived hydraulic heads is assessed on the basis of the average difference between the measured and model-derived values calculated in four ways (table 4). The arithmetic mean in table 4 is the sum of all differences, positive and negative, divided by the number of differences. The arithmetic mean greater than zero indicates that the model-derived potentiometric surface is generally too high. The mean absolute is the arithmetic mean of the absolute values of the differences. The mean absolute shows the overall goodness of fit without allowing positive and negative values to cancel each other, but it does not reveal the bias of the model-derived potentiometric surface. The median also reveals the overall goodness of fit without showing extreme differences, whereas the root-mean square accentuates the extreme differences. The root-mean square is the square root of the mean of the squares of the differences. Of these averages, the mean absolute is considered the best indicator of the relative goodness of each of the changed models. 
Table 4.--Average of differences between measured and model-derived hydraulic heads for the standard and each sensitivity test, in feet

$\left[\mathrm{K}\right.$ is horizontal hydraulic conductivity; $\mathrm{K}^{\prime}$ is vertical hydraulic conductivity; NW is northwest]

\begin{tabular}{|c|c|c|c|c|c|}
\hline Sensitivity test & $\begin{array}{c}\text { Number of } \\
\text { differences }\end{array}$ & $\begin{array}{c}\text { Arithmetic } \\
\text { mean }\end{array}$ & $\begin{array}{c}\text { Mean } \\
\text { absolute }\end{array}$ & Median & $\begin{array}{l}\text { Root-mean } \\
\text { square }\end{array}$ \\
\hline $\begin{array}{l}\text { Standard } \\
\text { Move Pajarito fault-boundary } \\
\text { specified flows to layer } 4\end{array}$ & $\begin{array}{l}297 \\
297\end{array}$ & $\begin{array}{l}11.7 \\
10.8\end{array}$ & $\begin{array}{l}53.4 \\
54.0\end{array}$ & $\begin{array}{l}16.0 \\
14.3\end{array}$ & $\begin{array}{l}69.5 \\
69.8\end{array}$ \\
\hline $\begin{array}{l}\text { Move Pajarito fault boundary to } \\
\text { layer } 4 \text { using greater flows }\end{array}$ & 297 & 18.0 & 57.6 & 28.2 & 73.0 \\
\hline $\begin{array}{l}K \text { in } N W \text { times } 0.5\left(K / K^{\prime} \text { same as }\right. \\
\text { standard) }\end{array}$ & 297 & 11.4 & 53.8 & 13.8 & 69.7 \\
\hline $\begin{array}{l}K \text { in } N W \text { times } 1.5\left(K / K^{\prime} \text { same as }\right. \\
\text { standard) }\end{array}$ & 297 & 11.8 & 53.6 & 18.4 & 69.5 \\
\hline $\begin{array}{l}K / K^{\prime}=100 \quad\left(K^{\prime} \text { times } 0.5\right) \\
K / K^{\prime}=40 \quad\left(K^{\prime} \text { times } 1.25\right)\end{array}$ & $\begin{array}{l}297 \\
297\end{array}$ & $\begin{array}{r}39.8 \\
4.6\end{array}$ & $\begin{array}{l}60.6 \\
53.6\end{array}$ & $\begin{array}{l}35.7 \\
13.2\end{array}$ & $\begin{array}{l}80.7 \\
69.6\end{array}$ \\
\hline $\begin{array}{l}\text { Standard } \\
\text { Storage times } 0.667 \\
\text { Storage times } 1.33 \\
\end{array}$ & $\begin{array}{l}113 \\
113 \\
113 \\
\end{array}$ & $\begin{array}{l}4.6 \\
0.9 \\
6.7 \\
\end{array}$ & $\begin{array}{l}54.2 \\
56.2 \\
53.2 \\
\end{array}$ & $\begin{array}{l}14.9 \\
11.4 \\
14.9 \\
\end{array}$ & $\begin{array}{l}70.5 \\
73.7 \\
68.8 \\
\end{array}$ \\
\hline
\end{tabular}

\footnotetext{
${ }^{1}$ The larger number includes both steady-state and transient data sets. The
} smaller number includes only the transient data set.

A hydrograph representing each well field is presented for each of the following sensitivity tests, and their general effect on model-derived hydraulic heads in each well field is discussed. In each graph the standard includes two projections (after 1992). The Guaje alternative in the projection is represented as a solid line. The chain-dot offshoot from the solid line projected after 1992 is the same except that the Pajarito-Otowi alternative is used in the projection. The effect of choosing the Guaje alternative over the Pajarito-Otowi alternative projected by the standard model is shown as the difference between the chain-dot line and the solid line. The changed model is shown by the dashed line representing the Guaje alternative and by a dotted offshoot representing the Pajarito-Otowi alternative. The effect of choosing the Guaje alternative projected by the changed model is compared to that of the standard by comparing the difference between the dotted and dashed lines with the difference between the chain-dot and solid lines. For clarity in the following discussions, the difference between alternatives is consistently described as the effect of selecting the Guaje alternative.

\section{Pajarito Fault Zone Recharge}

Recharge along the Pajarito Fault Zone was moved from layer 1 to layer 4 in two tests. In the first test, the specified-flow values of the standard, which are all in layer 1, were reassigned to layer 4. (That is, no recharge was specified for layer 1.) Although the overall fit of measured and model-derived hydraulic heads was not greatly affected, the mean absolute difference (table 4) was 0.6 foot greater than that of the standard. Fluctuations in hydrographs (fig. 24) of the changed model were the same as those of the standard model in the Los Alamos, Guaje, and Buckman well fields (fig. 24A, B, and D), where the dashed hydrographs (changed model) are indistinct from the solid hydrographs (standard). Hydraulic heads were lower in the Pajarito 
Mesa field (fig. 24C), especially at test wells (not shown) on the upgradient side of the well field. At well TW-4, hydraulic head was 70 feet lower in the changed model than in the standard model; at well TW-8, 14 feet lower; at well DT-5A, 20 feet lower; at well DT-9, 14 feet lower; and at well DT-10, 18 feet lower. Thus, the model-derived hydrograph of the changed model fit the measured values better than that of the standard at well TW-8 but not at well TW-4. The projected effect of the Guaje alternative was the same as that of the standard. The effect of this test on hydrographs for the Santa Fe area was not visible at the scale shown (fig. 24E).

In a second test, the specified-head boundary that had been used in a preliminary steadystate simulation to determine specified-flow recharge to layer 1 in the standard was used in a similar manner (a preliminary steady-state simulation) to determine specified-flow recharge to layer 4. (Again, no recharge was specified for layer 1.) The newly derived specified-flow values were somewhat larger than those of the standard. The overall fit of measured and model-derived hydraulic heads was not as good as that of the standard; the mean absolute difference (table 4) was 4.3 feet greater than that of the standard. Fluctuations in hydrographs (fig. 25) of the changed model were the same as those of the standard model. Because hydraulic heads were generally higher than those of the standard, however, the fit of measured and model-derived values was generally worse than that of the standard except for well TW-4 (not shown). The projected effect of the Guaje alternative was the same as that of the standard. The effect of this test on hydrographs for the Santa Fe area is a slight increase in hydraulic heads, barely visible at the scale shown (fig. 25E). It was concluded that the estimated effects of the Guaje alternative probably do not depend on the simulated vertical location of recharge along the Pajarito Fault Zone.

\section{Hydraulic Conductivity}

Sensitivity testing was done on both horizontal and vertical hydraulic conductivity. For horizontal hydraulic conductivity, two tests were compared to the standard:

a. Values in northwest part of the model decreased by 50 percent ( $K$ in NW times 0.5 )

b. Values in northwest part of the model increased by 50 percent (K in NW times 1.5)

For vertical hydraulic conductivity, two tests were compared to the standard:

a. Values in the model decreased by 50 percent $\left(K / K^{\prime}=100\right)$

b. Values in the model increased by 25 percent $\left(K / K^{\prime}=40\right)$

The results of the test in which assigned values of horizontal hydraulic conductivity were 0.5 times those of the standard was a mean absolute difference 0.4 foot greater than that of the standard (table 4). Fluctuations in hydrographs (fig. 26) were generally much greater for this test than for the standard in the Buckman, Los Alamos, Guaje, and Pajarito Mesa well fields. The greater fluctuations did not fit the measured values as well as did those of the standard. The projected effect of the Guaje alternative was about 200 percent of that of the standard in the Los Alamos well field (fig. 26A-C) and 152 percent in the Buckman well field. Although the effect of the Guaje alternative was not visible at the scale shown in hydrographs for the Buckman field, projected hydraulic heads were 3.1 feet higher at layer 5, row 13, column 11 with the Guaje alternative than with the Pajarito-Otowi alternative, as compared to a difference of 2.0 feet using the hydraulic-conductivity values of the standard. The effect of this test on hydrographs for the Santa Fe area was a slight increase in hydraulic heads, barely visible at the scale shown (fig. 26E). 


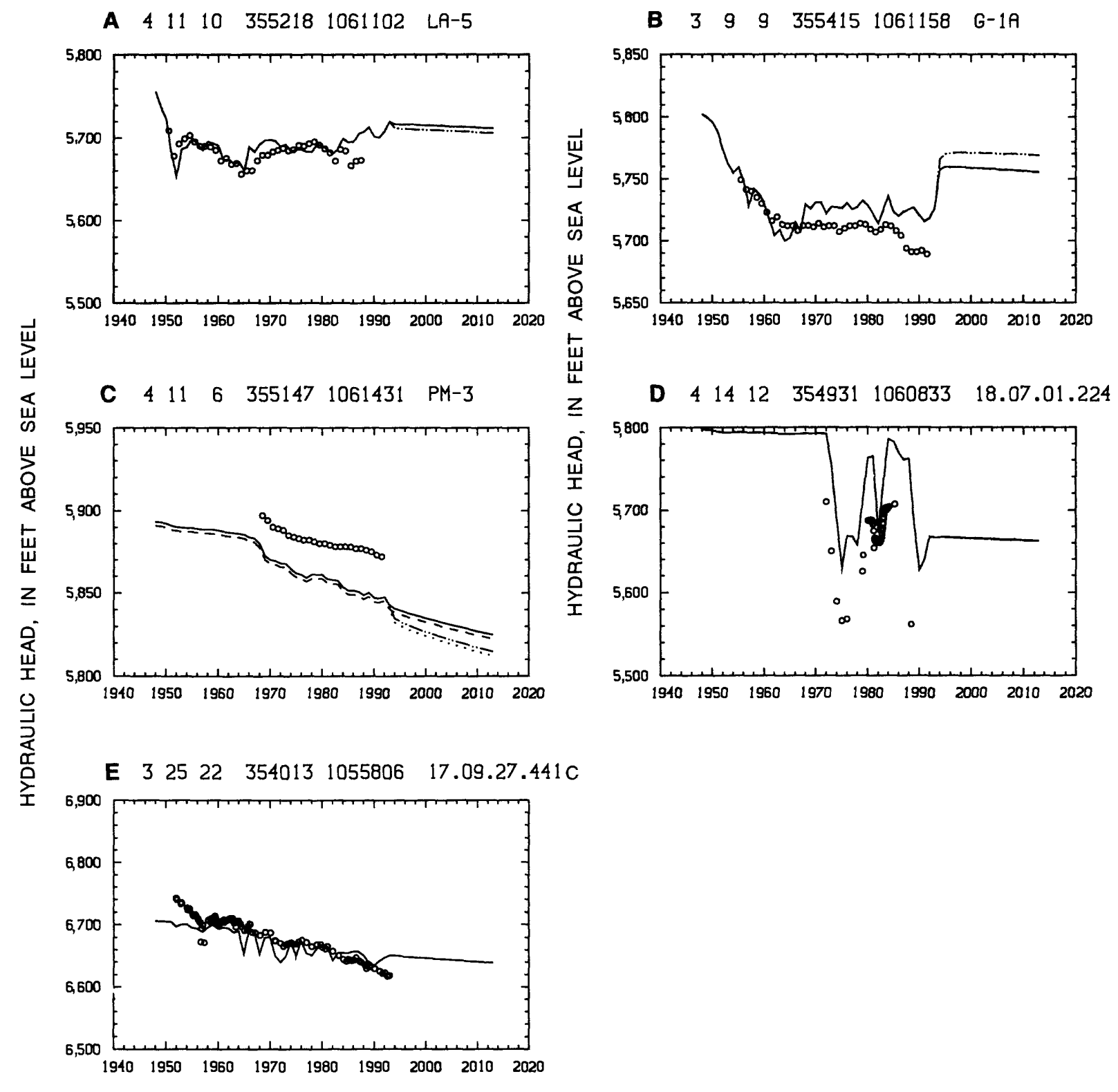

EXPLANATION

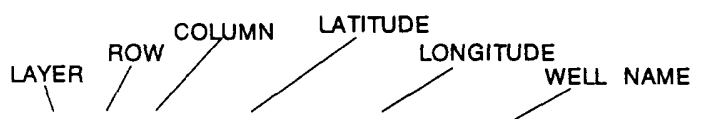

41163551471061431 PM-3

STANDARD USING GUAJE ALTERNATIVE AFTER 1993

-...- - STANDARD USING PAJARITO-OTOWI ALTERNATIVE AFTER 1993

- - - RECHARGE IN LAYER 4 USING GUAJE ALTERNATIVE AFTER 1993

......... RECHARGE IN LAYER 4 USING PAJARITO-OTOWI ALTERNATIVE AFTER 1993

- MEASURED HYDRAULIC HEAD

Figure 24.--Effect of moving specified-flow recharge of the Pajarito Fault Zone from layer 1 to layer 4 (location of wells shown in fig. 17). 
A $41110355218 \quad 1061102 \quad$ LA-5
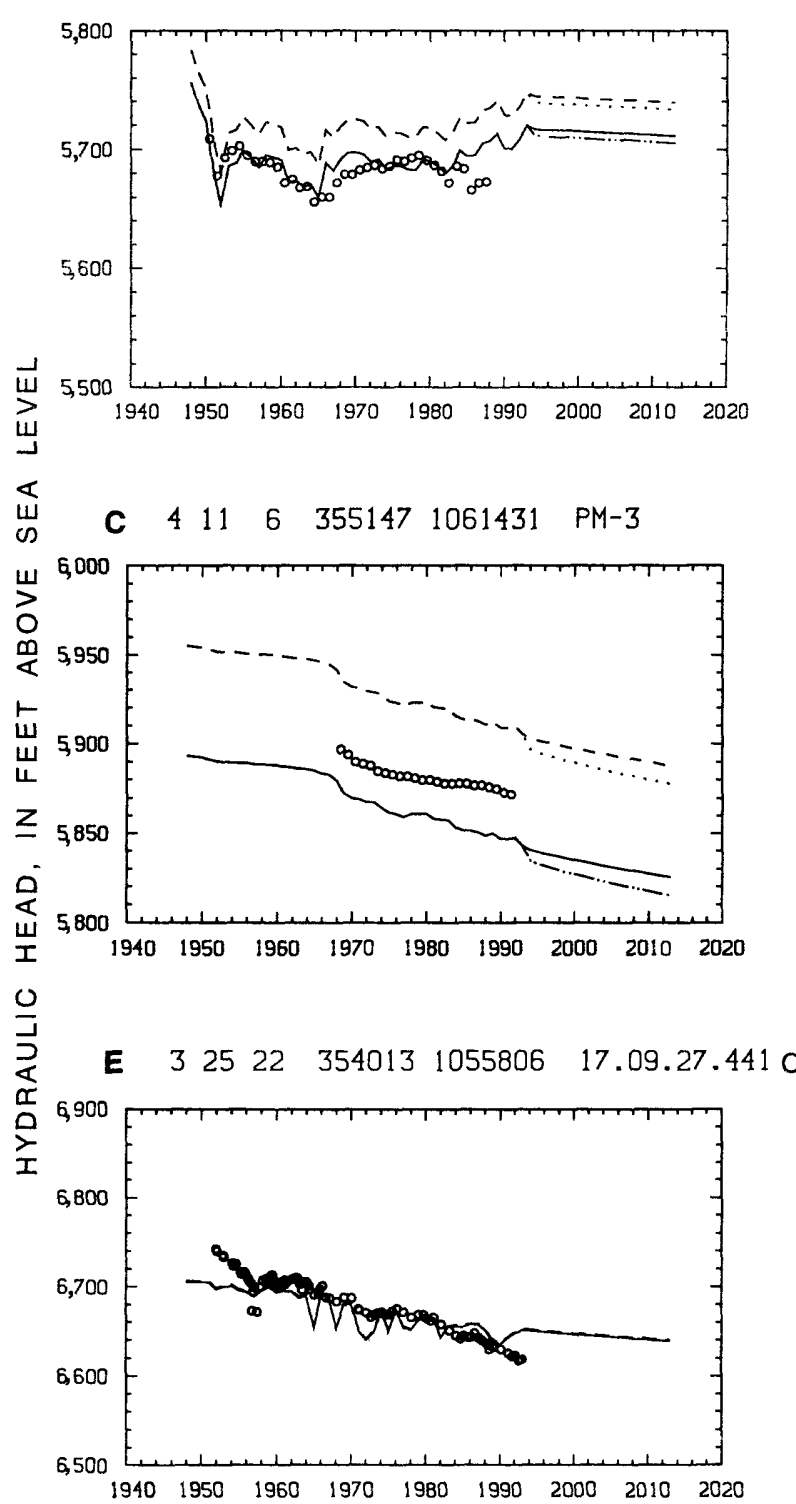

B $\quad 3 \quad 9 \quad 9 \quad 3554151061158 \quad$ G-1A
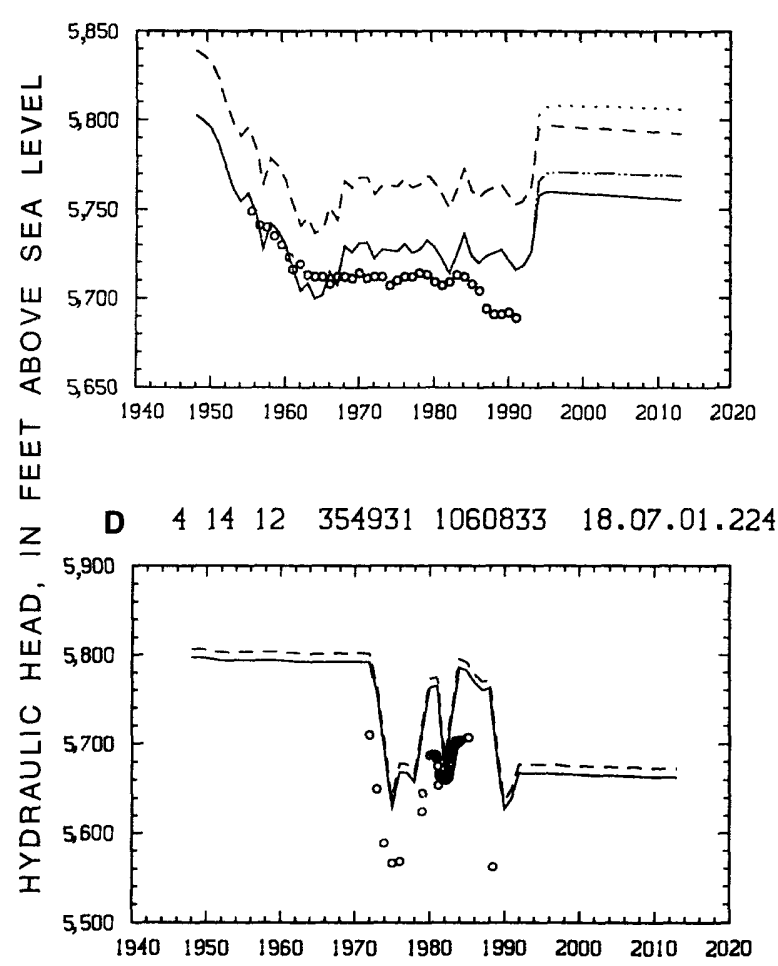

\section{EXPLANATION}

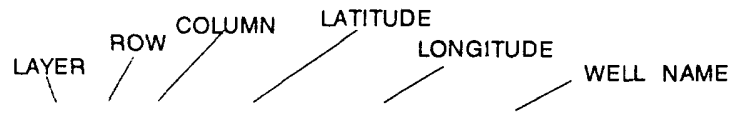

41163551471061431 PM-3

STANDARD USING GUAJE ALTERNATIVE AFTER 1993

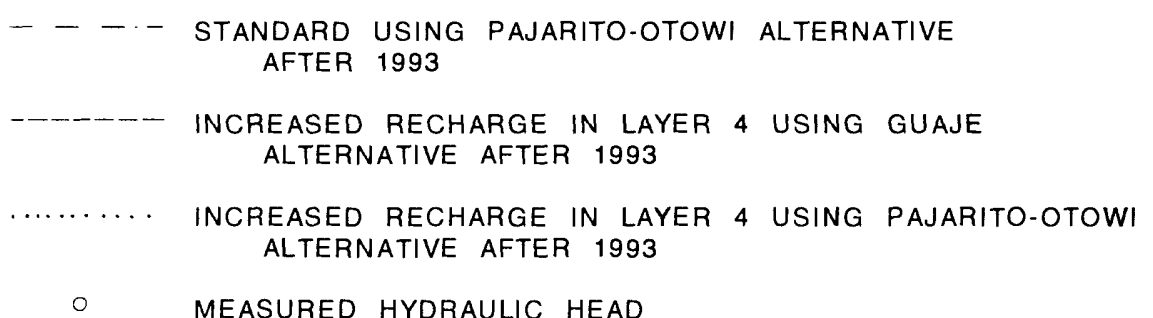

MEASURED HYDRAULIC HEAD

Figure 25.--Effect of moving specified-flow recharge of the Pajarito Fault Zone from layer 1 to layer 4, using larger flow values (location of wells shown in fig. 17). 


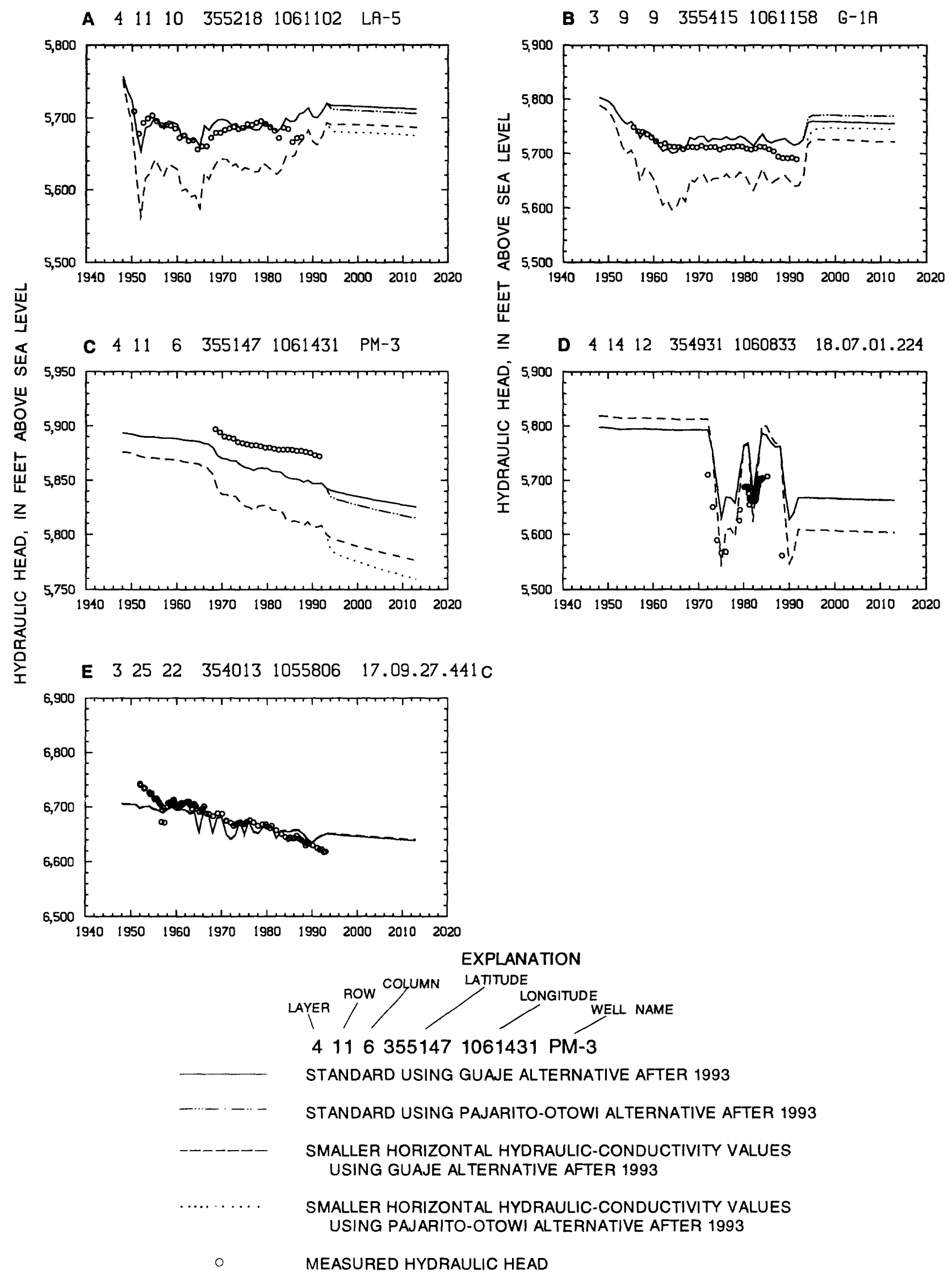

Figure 26.--Effect of using smaller horizontal hydraulic-conductivity values in the northwestern part of the model (location of wells shown in fig. 17). 
The sensitivity test in which horizontal hydraulic-conductivity values were increased to 1.5 times those of the standard had the following results: the mean absolute difference was 0.3 foot greater than that of the standard (table 4). Fluctuations in hydrographs (fig. 27) were generally less for this test than for the standard in the Buckman, Los Alamos, Guaje, and Pajarito Mesa well fields. The lesser fluctuations fit the measured values better than those of the standard at some sites in the Guaje and Pajarito Mesa fields (fig. 27B and C), but worse than those of the standard at some sites in the Los Alamos and Buckman fields (fig. 27A and D). The lesser fluctuations did not fit the measured values as well as did those of the standard at well G-2 in the Guaje field and at wells PM-2 and PM-4 in the Pajarito Mesa field (not shown). The slope of the potentiometric surface across the Guaje field (not shown) was less for this test than for that of the standard and did not fit the slope in the measured values as well as did that of the standard. The projected effect of the Guaje alternative was about 70 percent of that of the standard in the Los Alamos, Guaje, and Pajarito Mesa well fields and 79 percent in the Buckman well field. The effect of this test in the Santa Fe area is a slight decrease in hydraulic heads, barely visible at the scale shown (fig. 27E).

The test in which vertical hydraulic-conductivity values $\left(K^{\prime}\right)$ were decreased throughout the model by a factor of 0.5 times those of the standard $\left(K / K^{\prime}=100\right)$ had the following results: the mean absolute difference (table 4) was 7.2 feet greater than that of the standard. Fluctuations in hydrographs (fig. 28) were greater than those of the standard, and hydrographs generally did not fit the measured values as well as did those of the standard (fig. 28). Hydraulic heads were greater than those of the standard in the Los Alamos and Buckman well fields (fig. 28A and D), and less than those of the standard in the Guaje and Pajarito Mesa fields (fig. 28B and C); this generally did not improve the fit of measured and model-derived heads. Hydraulic heads were greater than those of the standard in the Santa Fe area (fig. 28E). The projected effect of the Guaje replacement wells was about 115 percent of those of the standard in the Los Alamos, Guaje, and Pajarito Mesa well fields and 144 percent in the Buckman well field.

The results of the test in which vertical hydraulic-conductivity values were increased throughout the model by a factor of 1.25 times those of the standard $\left(K / K^{\prime}=40\right)$ were mixed. Although the resulting arithmetic mean was less than that of the standard, the resulting mean absolute difference (table 4) was 0.2 foot greater than that of the standard. Fluctuations in hydrographs (fig. 29) were less than those of the standard, and although hydrographs fit the measured values better than those of the standard at a few sites (fig. 29C), they did not fit the measured values as well at other sites (fig. 29E). Hydrographs for the Los Alamos and Guaje well fields were little different from those of the standard (fig. 29A and B). Hydraulic heads were lower than those of the standard in the Santa Fe area (fig. 29E). The projected effect of the Guaje alternative was about 95 percent that of the standard in the Los Alamos, Guaje, and Pajarito Mesa well fields and 89 percent that of the standard in the Buckman well field. It was concluded that because these tests generally did not yield improvements in the comparison between measured and model-derived hydraulic heads, the hydraulic-conductivity values of the standard are plausible.

\section{Storage}

Sensitivity testing was done on storage values throughout the model. In one test storage values were decreased by a factor of 0.667 , and in the other test storage values were increased by a factor of 1.33. Statistics were calculated on the basis of transient (1977 and 1993) data because storage does not apply to steady-state conditions. 
A $41110 \quad 355218 \quad 1061102 \quad$ LA-5

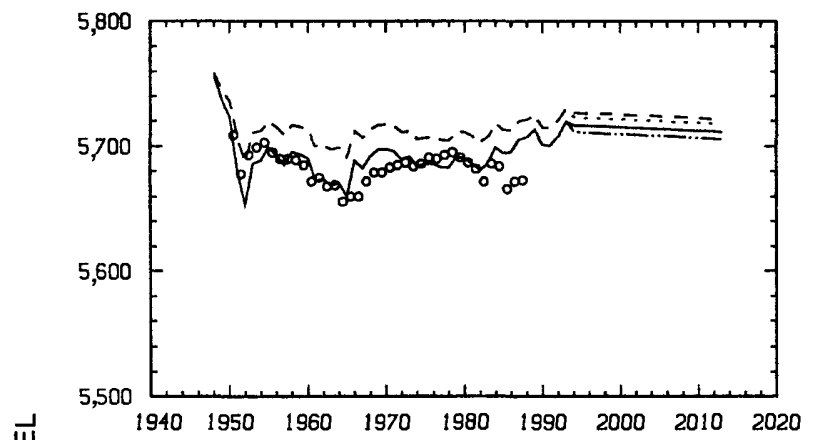

C $411 \quad 6 \quad 355147 \quad 1061431 \quad \mathrm{PM}-3$

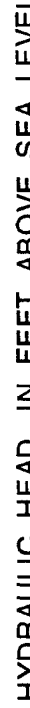

$$
\text { }
$$
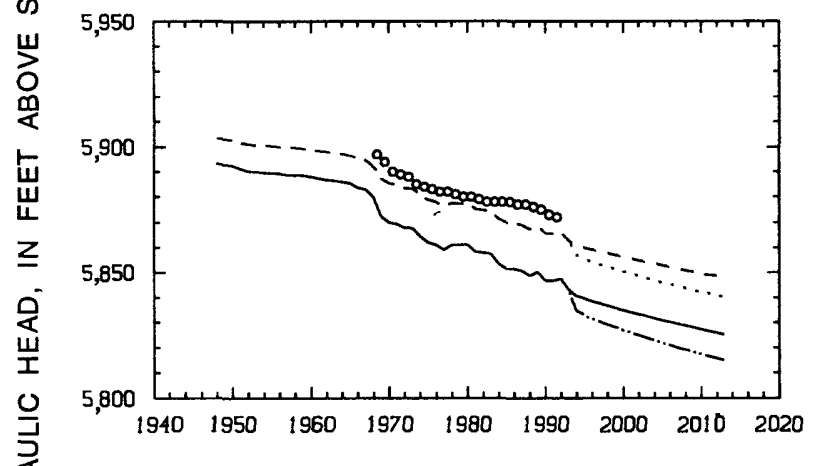

E $32522 \quad 354013 \quad 1055806 \quad 17.09 .27 .441 \mathrm{C}$
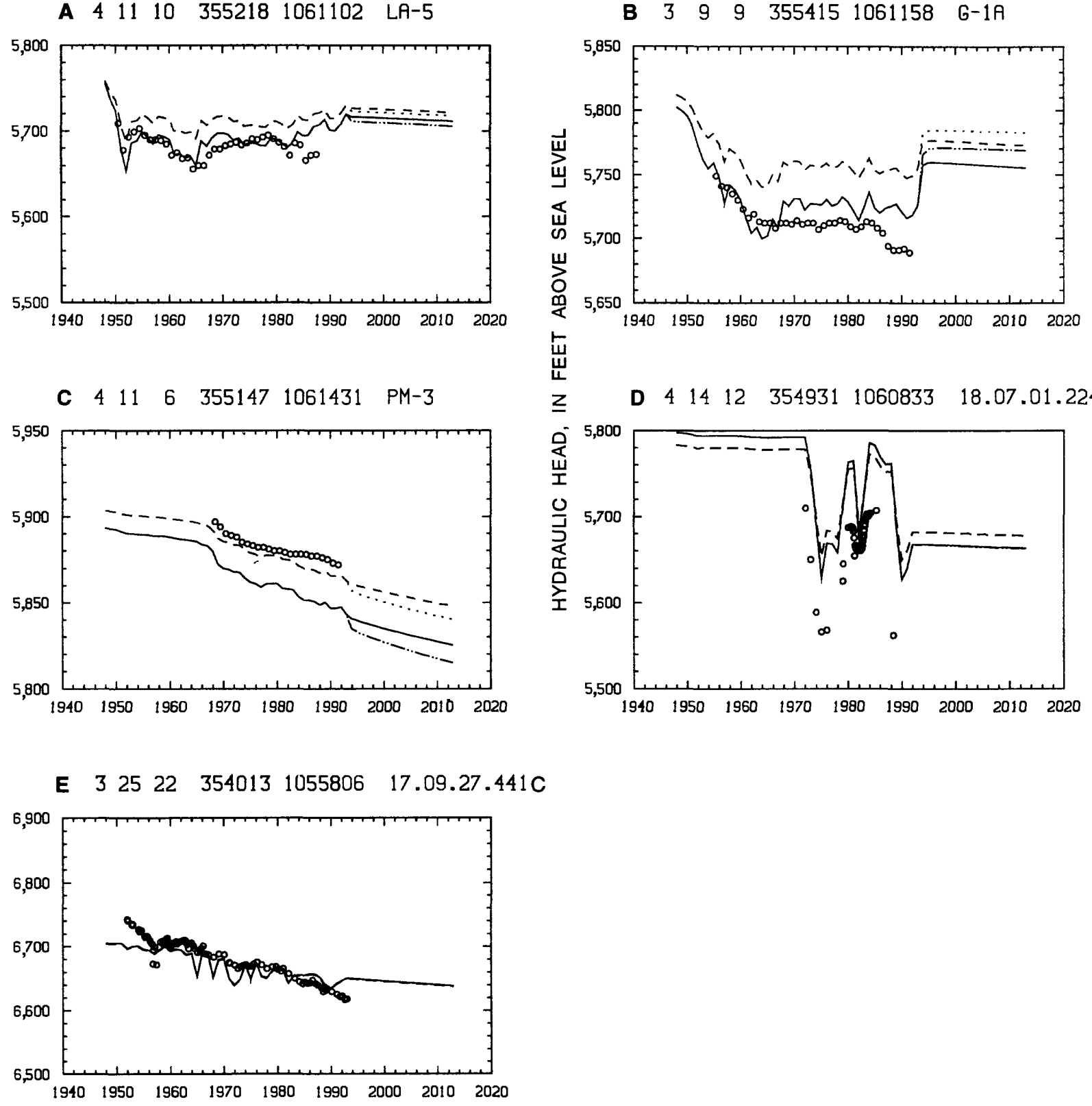

EXPLANATION

LAYER ROW COLUMN LATITUDE LONGITUDE WELL NAME

41163551471061431 PM-3

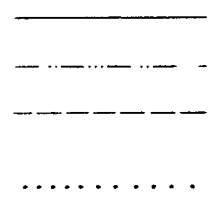

$\circ$

STANDARD USING GUAJE ALTERNATIVE AFTER 1993

STANDARD USING PAJARITO-OTOWI ALTERNATIVE AFTER 1993

LARGER HORIZONTAL HYDRAULIC-CONDUCTIVITY VALUES USING GUAJE ALTERNATIVE AFTER 1993

LARGER HORIZONTAL HYDRAULIC-CONDUCTIVITY VALUES USING PAJARITO-OTOWI ALTERNATIVE AFTER 1993

MEASURED HYDRAULIC HEAD

Figure 27.--Effect of using larger horizontal hydraulic-conductivity values in the northwestern part of the model (location of wells shown in fig. 17). 
A $411103552181061102 \quad$ LA-5

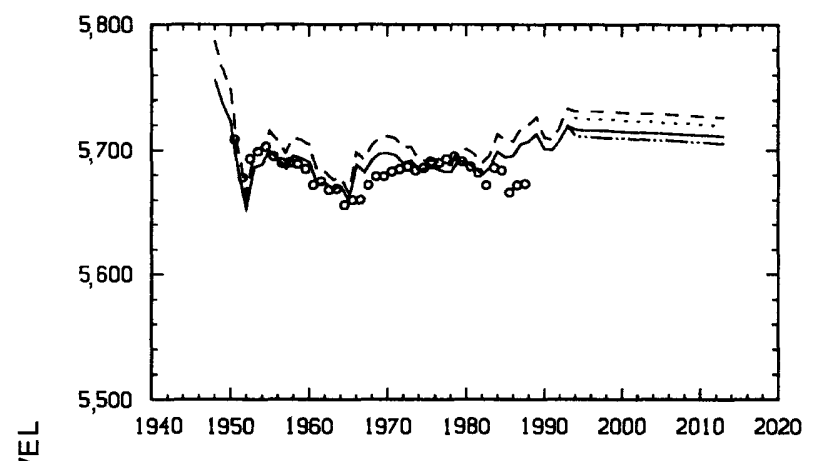

C $4 \begin{array}{llllll}11 & 6 & 355147 & 1061431 & P M-3\end{array}$

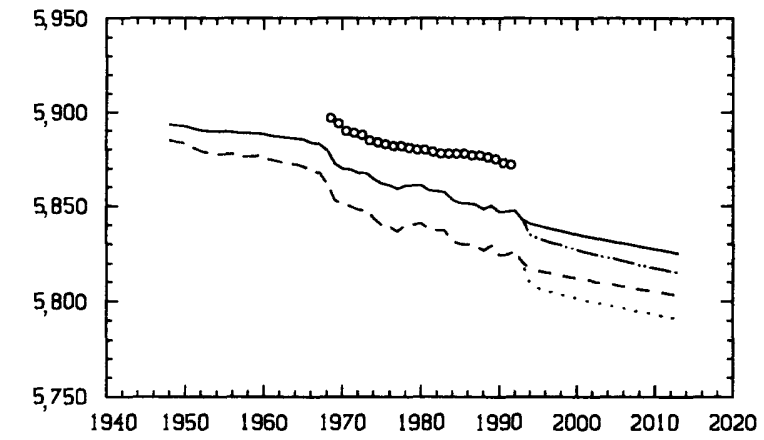

B $3 \begin{array}{llllllll} & 3 & 9 & 355415 & 1061158 & G-1 A\end{array}$
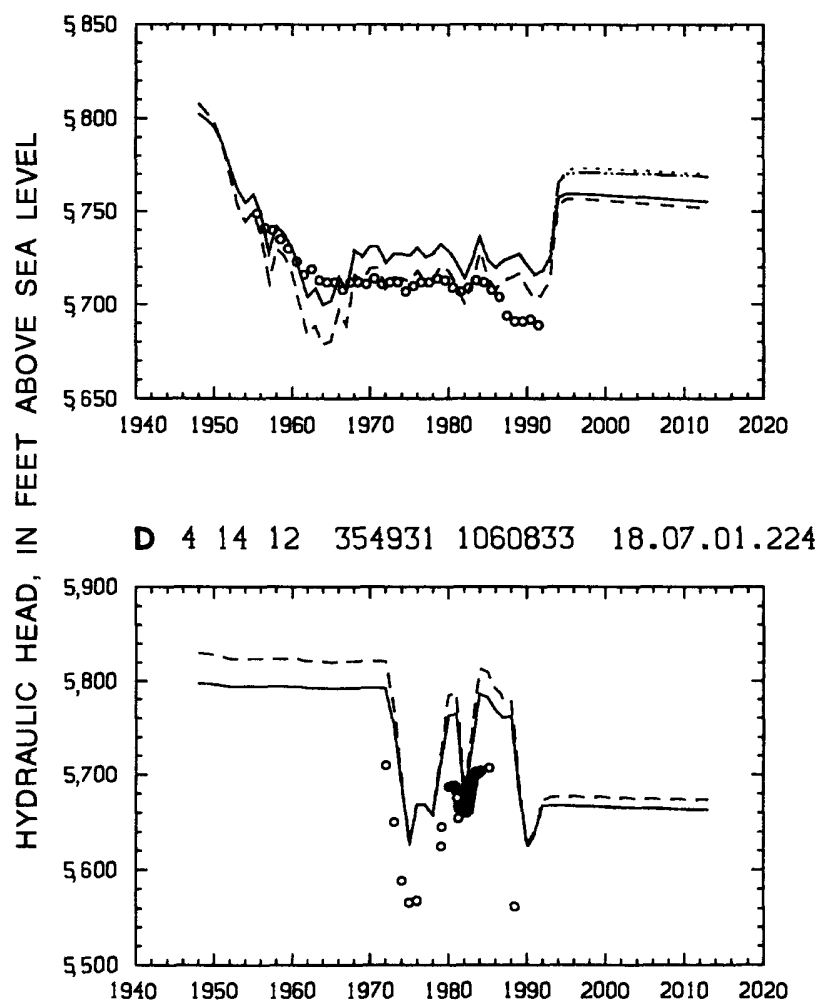

E $32522 \quad 354013 \quad 1055806 \quad 17.09 .27 .441 \mathrm{C}$

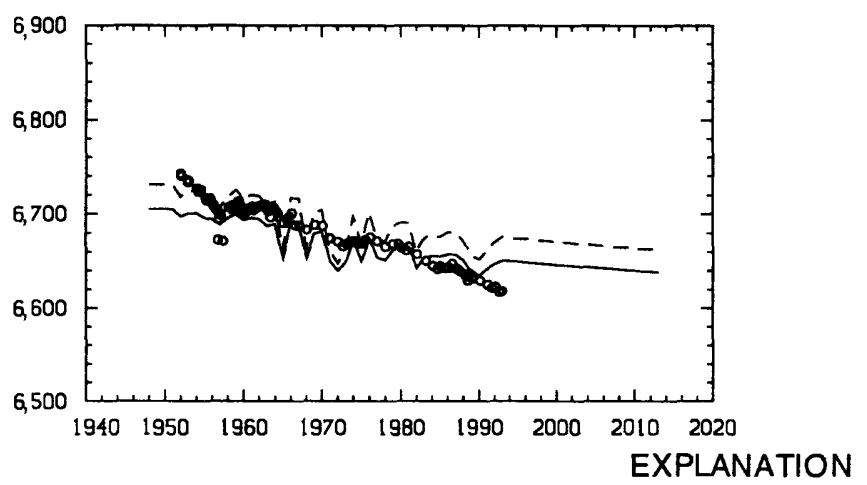

LAYER ROW COLUMN LATITUDE LONGITUDE

WELL NAME

41163551471061431 PM-3

STANDARD USING GUAJE ALTERNATIVE AFTER 1993

- . - - - STANDARD USING PAJARITO-OTOWI ALTERNATIVE AFTER 1993

SMALLER VERTICAL HYDRAULIC-CONDUCTIVITY VALUES USING GUAJE ALTERNATIVE AFTER 1993

SMALLER VERTICAL HYDRAULIC-CONDUCTIVITY VALUES USING PAJARITO-OTOWI ALTERNATIVE AFTER 1993

- MEASURED HYDRAULIC HEAD

Figure 28.--Effect of using smaller vertical hydraulic-conductivity values (location of wells shown in fig. 17). 
A $41110 \quad 3552181061102 \quad$ LA-5
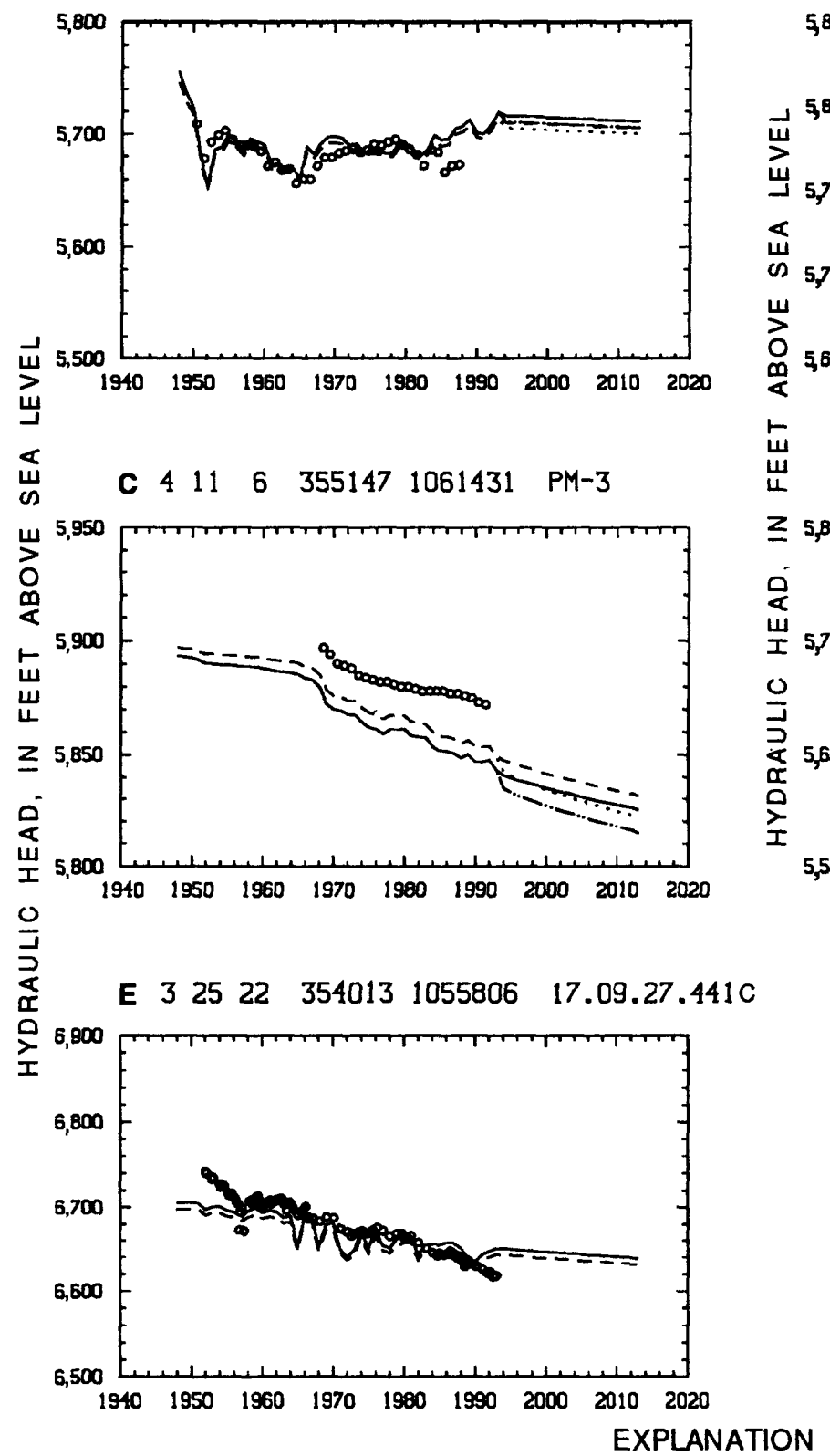

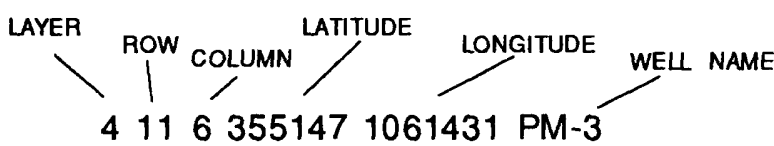

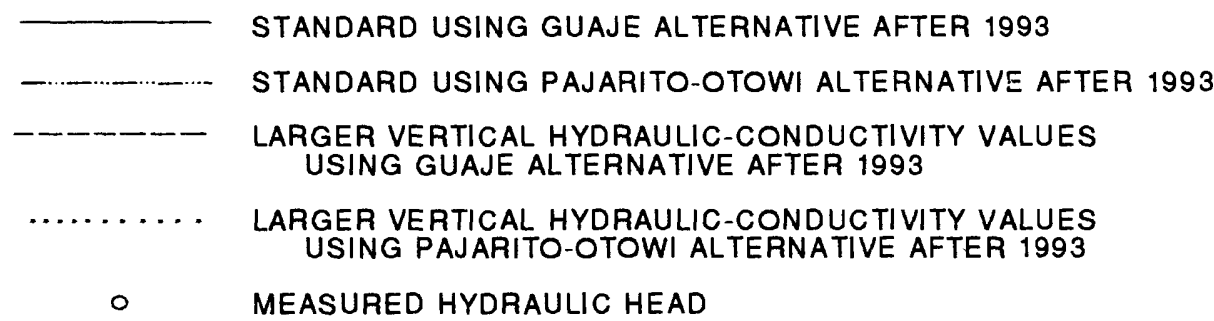

Figure 29.--Effect of using larger vertical hydraulic-conductivity values (location of wells shown in fig. 17). $\begin{array}{llllllll}\text { B } & 3 & 9 & 9 & 355415 & 1061158 & \text { G-1A }\end{array}$
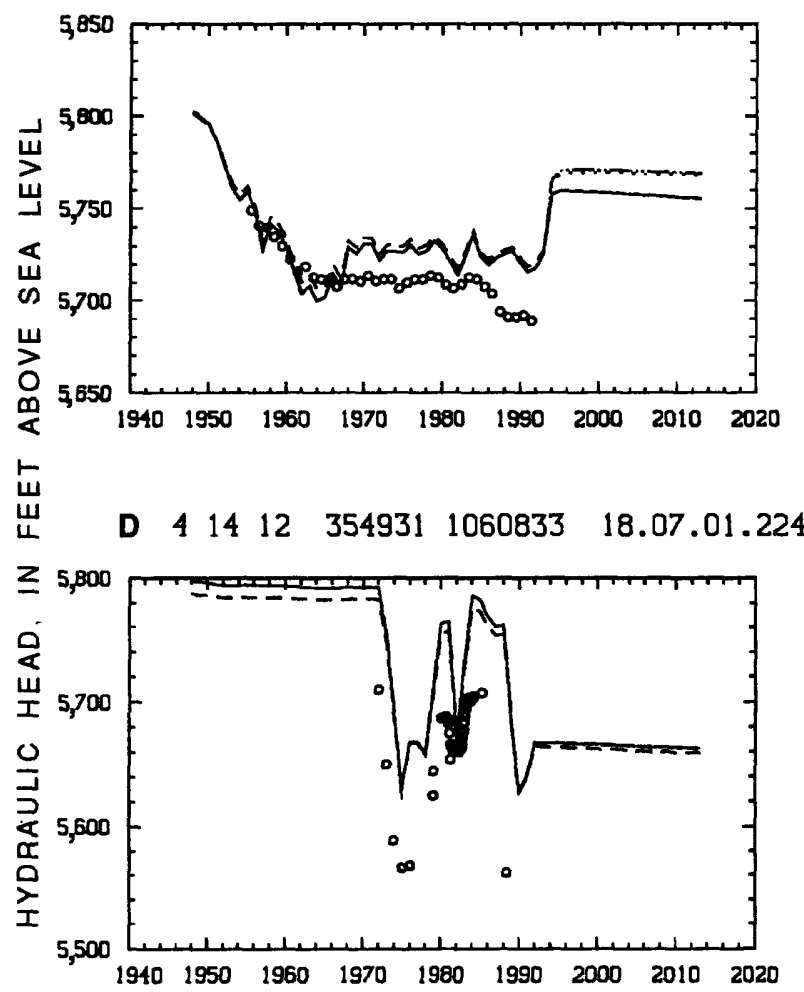
The test in which storage values throughout the model were decreased by a factor of 0.667 had the following results: the mean absolute difference (table 4) was 2 feet greater than that of the standard. Fluctuations in hydrographs (fig. 30) were greater than those of the standard. Although a long-term trend of more drawdown than that of the standard resulted in an improved fit of model-derived to measured hydraulic heads at some locations in the Guaje field (fig. 30B), the same trend resulted in a poorer fit at other locations in the Pajarito Mesa field (fig. $30 \mathrm{C})$. Hydrographs for the Los Alamos and Buckman fields were little different from those of the standard (fig. 30A and D). Some hydrographs in the Santa Fe area fit the measured values better than those of the standard (fig. 30E). The projected effect of the Guaje alternative was about 105 percent that of the standard in the Los Alamos, Guaje, and Pajarito Mesa well fields and 107 percent in the Buckman well field.

Statistical results of the test in which storage values throughout the model were increased by a factor of 1.33 were mixed. The mean absolute difference (table 4 ) was 1.0 foot less than that of the standard, indicating an overall better fit of model-derived and measured values, a conclusion supported by the other averages except the mean. Fluctuations in hydrographs (fig. 31) were less than those of the standard. Hydrographs for the Los Alamos, Guaje, and Buckman well fields were little different from those of the standard (fig. 31A, B, and D). Although at some locations, such as well PM-3 (fig. 31C), a long-term trend of less drawdown than that of the standard resulted in a better fit of model-derived to measured heads, the same trend resulted in a poorer fit at other sites such as wells PM-1 and PM-2 (not shown). Hydrographs for the Santa Fe area (fig. 31E) generally did not fit measured values as well as those of the standard. The projected effect of the Guaje alternative was about 95 percent that of the standard in the Los Alamos, Guaje, and Pajarito Mesa well fields and 97 percent in the Buckman well field. It was concluded that the effects of the Guaje and Pajarito-Otowi alternative projected by the standard could be overestimated as a result of the storage values used. The storage values of the standard could be too small. Larger storage values would tend to reduce drawdowns and dampen the effect of either alternative.

\section{Predictive Capability}

The standard model reproduces measured hydraulic heads and head fluctuations fairly well and should be useful for predicting the drawdown effects of the Guaje alternative. Modelderived hydraulic heads of the standard model match measured values better than any of the sensitivity tests except the test where greater storage was simulated. Although the effect of the Guaje alternative predicted by the standard is a very small part of drawdown at the Buckman well field, greater storage would tend to result in less effect from ground-water withdrawals than that of the standard.

Use of this model for other purposes such as the estimation of ground-water-flow path lines for a chemical transport model would not be appropriate because the model is much simpler than the geohydrologic system. Although fluctuations in measured hydrographs are approximately matched, the model-derived hydrographs are often substantially above or below the measured hydrographs. That is, the differences between the solid and dashed lines in figures 18-22 are often as much as 50 feet. This is probably because the aquifer is heterogeneous, and the rate of ground-water movement is greater than average in the more permeable zones, leading to paths that are more complex than the paths that the model simulates. The model does not account for the structure of the Tesuque Formation or detailed variations in hydraulic conductivity of the Chaquehui formation and Puye Formation and of the basaltic rocks that are buried within the Chaquehui and Puye. Also, the location and rate of recharge are not known, though recharge is thought to occur somewhere near the western side of the Pajarito Plateau. 
A $41110355218 \quad 1061102 \quad$ LA-5

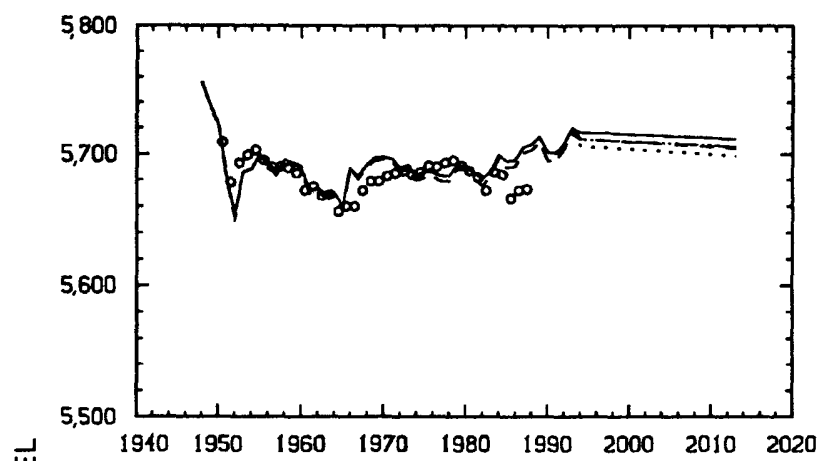

岁

欪

C $41116 \quad 355147 \quad 1061431 \quad \mathrm{PM}-3$

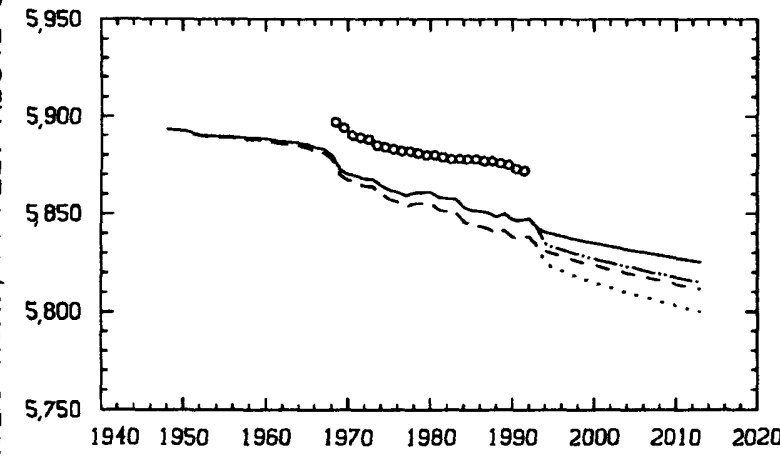

E $32522 \quad 354013 \quad 1055806 \quad 17.09 .27 .441 \mathrm{C}$

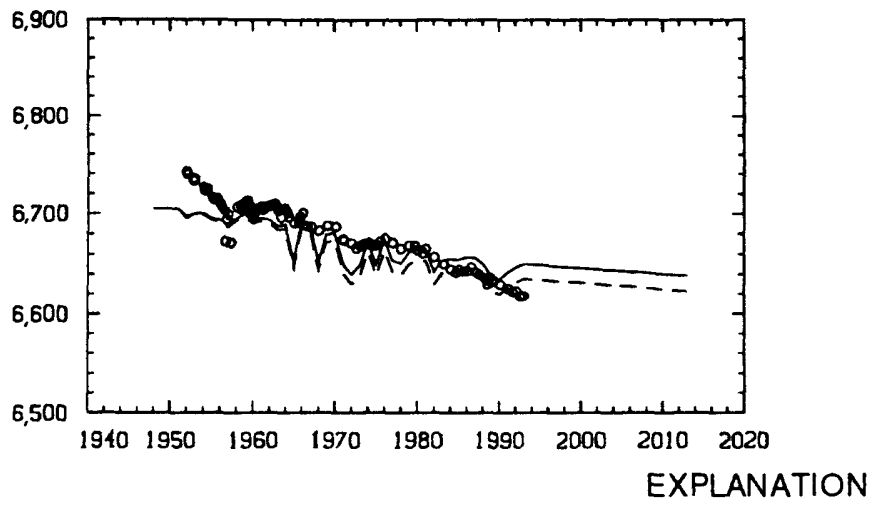

B $3 \begin{array}{lllllll}3 & 9 & 9 & 355415 & 1061158 \quad G-1 A\end{array}$

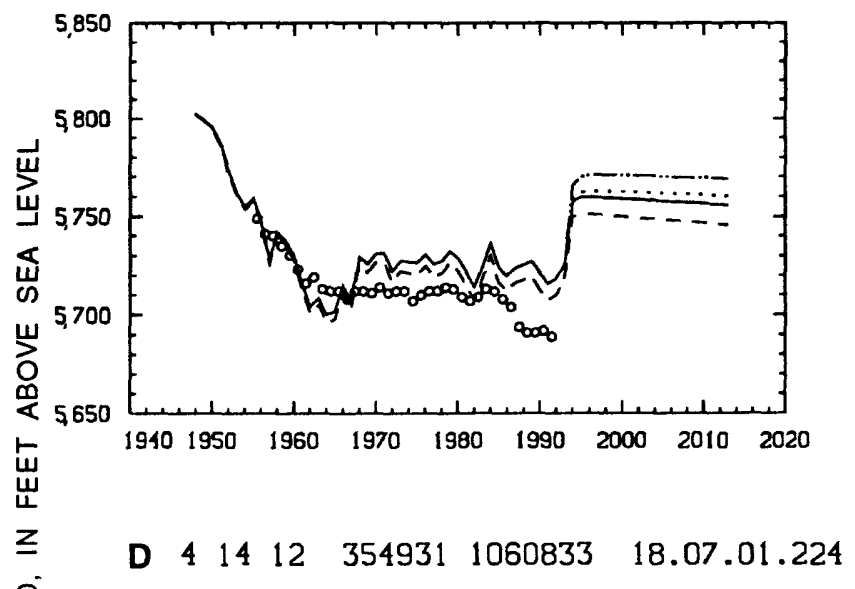

Q 5000

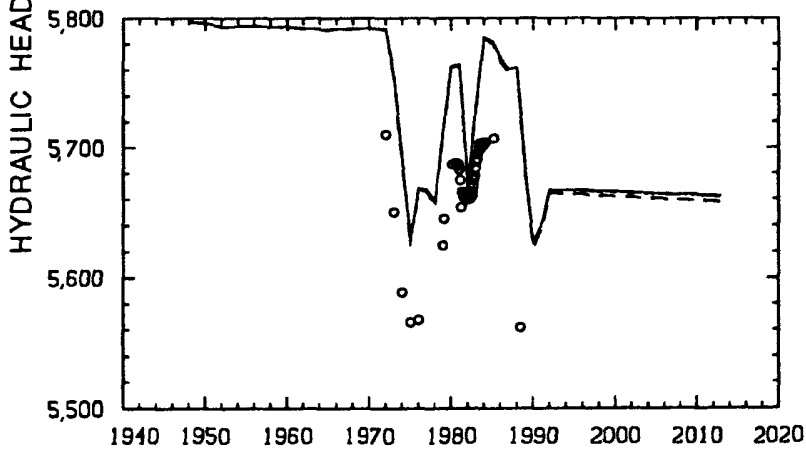

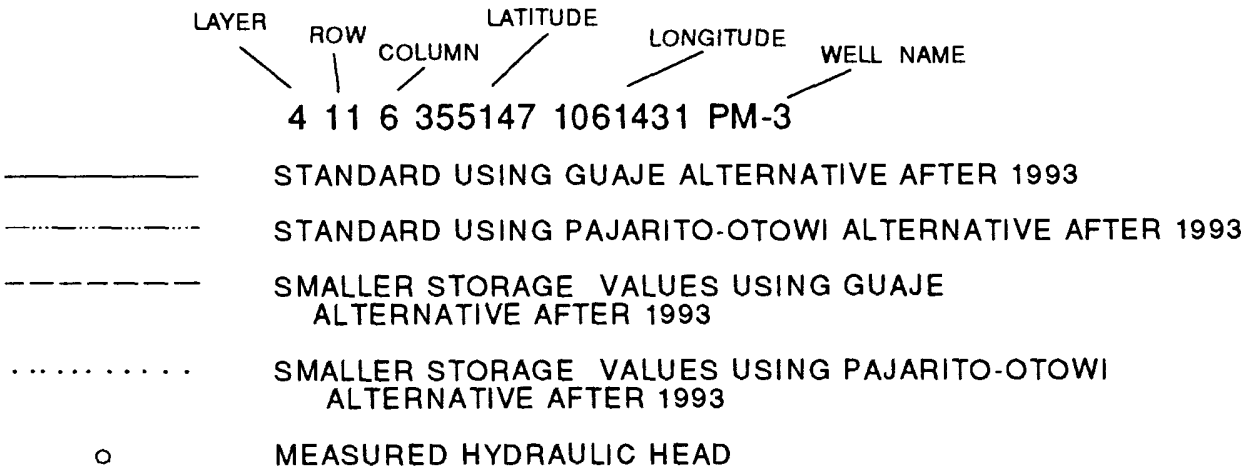

Figure 30.--Effect of using smaller storage values (location of wells shown in fig. 17). 


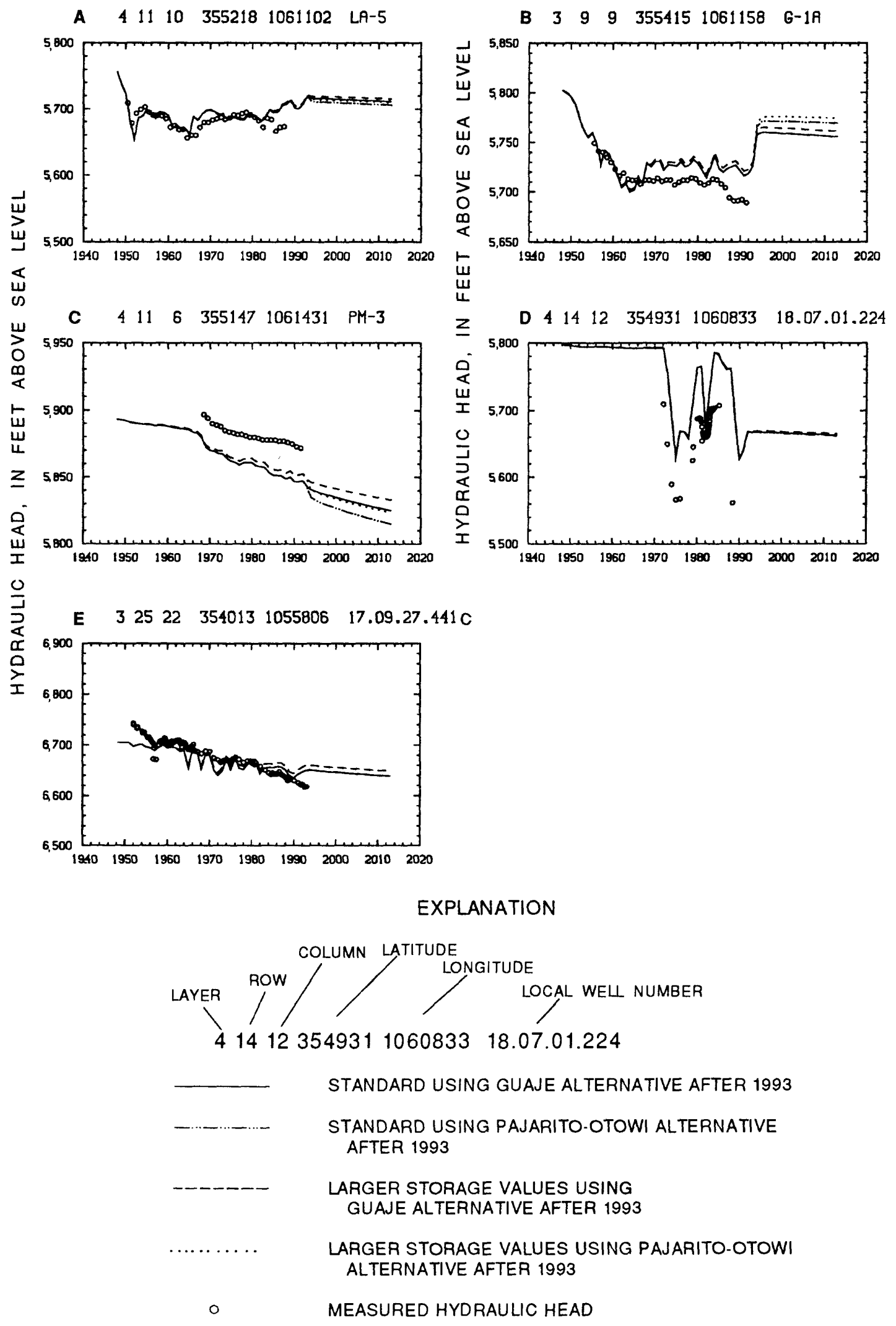

Figure 31.--Effect of using larger storage values (location of wells shown in fig. 17). 


\section{DATA NEEDS FOR AN IMPROVED UNDERSTANDING OF THE FLOW SYSTEM}

Environmental considerations make contaminant transport modeling of the Pajarito Plateau in the vicinity of LANL a possibility. An improved understanding of the flow system would be desirable if a contaminant transport model were to be constructed. The data needs of a specific contaminant transport model would depend on the contaminant, the location of the contaminant source, the distance the contaminant has been transported by ground water, and the objectives of the transport model. However, a flow model would first need to be developed to provide a reliable approximation of flow path lines in the vicinity where a contaminant transport model might be attempted. Although the model described in this report is adequate for the purpose of distinguishing the effects of the Guaje and Pajarito-Otowi alternatives on hydraulic heads at the Buckman well field, a reliable simulation of ground-water-flow path lines for contaminant transport probably would require a better understanding of the hydrologic characteristics of the Pajarito Plateau and adjacent areas.

Determination of the location and quantity of recharge to the aquifer(s) of the Pajarito Plateau would be useful. Although estimates of the age and recharge altitude of water from production wells are useful evidence, water from production wells is likely to be a mixture of water from all strata from which the well withdraws water. Water from production wells could come by various flow paths, which would make conclusions about age and recharge altitude difficult and tenuous. The age and recharge altitude of water samples collected from discrete points in the three-dimensional flow field would be more useful for determining the location of recharge and rate of ground-water movement. Along with age and recharge altitude, horizontal and vertical gradients, saturated and unsaturated hydraulic-conductivity values, and degree of saturation in the vicinity of the Pajarito Fault Zone could help indicate the source of recharge. The magnitude of reported hydraulic-conductivity values of the Bandelier Tuff under saturation conditions would allow for recharge wherever a constant supply of water is available to maintain saturation. The Bandelier could be saturated beneath perennial streams where they enter the west side of the Pajarito Plateau. If recharge is substantial beneath perennial streams, then the location of a substantial part of recharge probably has changed because surface water has been diverted from perennial streams and reintroduced at points downstream from sewer plants. This change probably has not occurred suddenly because of storage in the thick unsaturated zone between the perched alluvial aquifers and the water table of the main aquifer. Thus, along streams two transient situations would exist: zones of decreasing recharge and zones of increasing recharge. On much of the area of the Pajarito Plateau, evapotranspiration could be about the same as precipitation, thus limiting recharge, and a substantial chloride buildup might be present in the soil and in the top of the Bandelier Tuff. A chloride buildup could be verified in the field at relatively low cost compared to other subsurface geologic investigations.

Accurate, long-term records of ground-water withdrawals and nonpumping hydraulic heads are valuable because they provide what is in effect a long-term aquifer test. Continued observations and record keeping are essential. Vertically integrated data derived from wells that are open over several aquifer zones are useful, but data more specific to thinner zones might be more conclusive.

Patterns of water-yielding characteristics within the Chaquehui formation, Puye Formation, and interbedded basaltic rocks would be useful. The zones of extreme (large or small) hydraulic conductivity would be of particular concern, whether in the main aquifer, perched aquifers, or zones located vertically between aquifers. For example, large zones of the basaltic rocks, if they are massive, could have very small hydraulic conductivity, porosity, and storage coefficient; depending on fractures, however, such zones could be penetrated by solutes more quickly than a porous medium having a similar hydraulic conductivity. Also, a consistent dip or orientation of the beds and lenses of the Chaquehui and Puye could result in anisotropy that 
could affect the direction and rate of movement along flow paths. Any information on water quality, rock/water interactions, and penetration of tracers would be useful in refining concepts of the flow system.

Water-level, geologic, and aquifer-characteristic data for the northern extremity of the Pajarito Plateau (north of Los Alamos County), especially between the county line and Santa Clara Canyon, would be useful. Geohydrologic characteristics of that area, which lies adjacent to the Guaje well field, are almost completely unknown. On the basis of extremely sparse data, Purtymun and Johansen (1974, fig. 3) indicated a southward component of flow into Los Alamos County from that area.

The possible southward extent of the Chaquehui formation through the southern extremity of the Pajarito Plateau could have a bearing on flow paths because the Chaquehui is more permeable than the Tesuque Formation. For example, if the Chaquehui were to extend unfaulted southward past St. Peter's Dome toward the Santo Domingo Basin, the resulting changes in ground-water flow could affect flow path lines in other areas of the Pajarito Plateau.

An understanding of the Tesuque aquifer system east of the Pajarito Plateau would be needed to simulate reasonable boundary conditions for the main aquifer of the Pajarito Plateau. In approximate order of usefulness, improved understanding of streamflow gains along the Rio Grande, the dip on beds of the Tesuque Formation, the transient effects of Cochiti Reservoir (Lake) recharge estimates for the Tesuque, estimates of ground-water withdrawals north of Santa $\mathrm{Fe}$, the destination of sewer-plant effluent in the Santa Fe area, and estimates of hydraulic conductivity and aquifer thickness south of Santa Fe would be useful.

The dip and extent of the Tesuque Formation could have a significant effect on flow paths. The westward-dipping beds could result in westward flow at depth beneath the eastern part of the Pajarito Plateau. The possible westward extent of the Tesuque beyond the Pajarito Fault Zone could allow for more flow across the Pajarito Fault Zone at depth than would be likely if rocks west of the Pajarito Fault Zone are less permeable than the Tesuque Formation.

\section{SUMMARY AND CONCLUSIONS}

The model of McAda and Wasiolek was modified in recognition of new geohydrologic interpretation and adjusted to simulate hydrographs in well fields in the Los Alamos area. Hydraulic-head drawdowns at the Buckman well field resulting from withdrawals at four scheduled replacement wells in the Guaje well field were estimated with the modified model. The Chaquehui formation (informal usage) is the main new feature of recent geohydrologic interpretations. The Chaquehui occupies a "channel" that was eroded or faulted into the Tesuque, and the Chaquehui is more permeable than the Tesuque. The Chaquehui is a major producing zone in the Pajarito Mesa well field and to a a lesser extent in the Guaje well field. Model modification included splitting the four layers of the McAda-Wasiolek model into eight layers to better simulate vertical ground-water movement. Minor adjustments were made in the La Cienega area to avoid having model-derived hydraulic heads lower than the bottom of the top layer. Otherwise, model modifications were limited as much as possible to the area of interest near Los Alamos and Buckman and consisted mainly of adjusting hydraulicconductivity values representing the Tesuque Formation, Chaquehui formation, and Puye Formation, and adjusting simulated recharge along the Pajarito Fault Zone west of Los Alamos. Initial adjustments of hydraulic conductivity near Los Alamos were based on recent geological interpretations of the Chaquehui and Puye. Adjustments of hydraulic conductivity and recharge 
were based mainly on the simulation of fluctuations in measured hydraulic heads near Los Alamos and Buckman. Storage values were adjusted but final values were approximately the same as those of the McAda-Wasiolek model. Although sensitivity testing seemed to indicate that storage values could be too small, larger storage values tended to decrease drawdowns and dampen the effect of the Guaje replacement wells. Variations of hydraulic conductivity and recharge used during sensitivity tests resulted in simulations that were not as good as the standard.

Two possible alternative plans for replacing Guaje well field production were suggested by LANL. In the first plan (Guaje alternative), four new wells would replace existing production wells in the Guaje field. In the second plan (Pajarito-Otowi alternative), the Guaje field would be retired and its former production would be made up by additional withdrawals from the Pajarito Mesa and Otowi well fields. A projection for each of these alternatives was made using the new eight-layer model. In the Guaje field, projected hydraulic heads were as much as 50 feet lower with the Guaje alternative, and in the Pajarito Mesa field, hydraulic heads were as much as 12 feet higher with the Guaje alternative. At the western end of the Los Alamos well field, projected hydraulic heads were about 20 feet higher with the Guaje alternative; at the eastern end of the Los Alamos field, the effect of the Guaje alternative was much smaller. At the Buckman well field, projected hydraulic heads were about 2 feet higher with the Guaje alternative because the Buckman field is closer to the Pajarito Mesa field than to the Guaje field.

Ways of improving the understanding of the flow system include developing a more accurate representation of the structure and extent of the Tesuque Formation, Chaquehui formation, and Puye Formation of the Santa Fe Group and obtaining more detailed geologic and hydrologic characteristics of the Chaquehui formation and Puye Formation. Data that describe water chemistry, hydraulic head, and degree of saturation could be used to determine the location and quantity of recharge on the Pajarito Plateau, especially along the west side and in canyon bottoms. Chloride concentrations in soil at the top of the Bandelier Tuff could be used to verify the concept that evapotranspiration accounts for nearly all precipitation over a large area of the plateau. 


\section{REFERENCES}

Abrahams, J.H., Jr., Weir, J.E., and Purtymun, W.D., 1961, Distribution of moisture in soil and nearsurface tuff on the Pajarito Plateau, Los Alamos County, New Mexico, in Geological Survey Research 1961: U.S. Geological Survey Professional Paper 424-D, p. 142-145.

Anderholm, S.K., 1994, Ground-water recharge near Santa Fe, north-central New Mexico: U.S. Geological Survey Water-Resources Investigations Report 94-4078, 68 p.

Baltz, E.H., 1978, Resume of the Rio Grande Depression in north-central New Mexico, in Guidebook to Rio Grande rift in New Mexico and Colorado: Socorro, New Mexico Bureau of Mines and Mineral Resources Circular 163, p. 210-228.

Borton, R.L., 1968, General geology and hydrology of north-central Santa Fe County, New Mexico: New Mexico State Engineer Office Open-File Report, 21 p.

Budding, A.J., 1978, Gravity survey of the Pajarito Plateau, Los Alamos and Santa Fe Counties, New Mexico: Los Alamos Scientific Laboratory Informal Report LA-7419-MS, 15 p.

Environmental Protection Group, 1993 (August), Environmental surveillance at Los Alamos during 1991: Los Alamos National Laboratory Report LA-12572-ENV, variously paged.

Finch, S.T., Jr., and Fleming, W.M., 1992, Recalibration of the USGS-SEO Santa Fe ground-water model using revised recharge estimates: John W. Shomaker, Inc. consultant report prepared for the Santa Fe Metropolitan Water Board, 22 p.

Freeze, R.A., and Cherry, J.A., 1979, Groundwater: Englewood Cliffs, N.J., Prentice-Hall, 604 p.

Galusha, Ted, and Blick, J.C., 1971, Stratigraphy of the Santa Fe Group, New Mexico: American Museum of Natural History Bulletin, v. 144, article 1, 127 p.

Griggs, R.L., 1964, Geology and ground-water resources of the Los Alamos area, New Mexico: U.S. Geological Survey Water-Supply Paper 1753, 107 p., 1 pl.

Hearne, G.A., 1985, Mathematical model of the Tesuque aquifer system near Pojoaque, New Mexico: U.S. Geological Survey Water-Supply Paper 2205, 75 p.

Johnson, A.I., 1967, Specific yield--compilation of specific yields for various materials: U.S. Geological Survey Water-Supply Paper 1662-D, 74 p.

Kelley, V.C., 1978, Geology of Española Basin, New Mexico: Socorro, New Mexico Bureau of Mines and Mineral Resources Geologic Map 48, scale 1:125,000.

Lee Wilson and Associates, 1978, Santa Fe County water plan: Consultant report, variously paged.

Lohman, S.W., 1972, Ground-water hydraulics: U.S. Geological Survey Professional Paper 708, $70 \mathrm{p}$.

Los Alamos National Laboratory, 1993, Installation work plan for environmental restoration, revision 3, November 1993: Los Alamos National Laboratory Report LA-UR-93-3987, variously paged.

Manley, Kim, 1978a, Cenozoic geology of Española Basin, in Guidebook to Rio Grande rift in New Mexico and Colorado: Socorro, New Mexico Bureau of Mines and Mineral Resources Circular 163, p. 201-210.

1978b, Structure and stratigraphy of the Española Basin, Rio Grande rift, New Mexico: U.S. Geological Survey Open-File Report 78-667, 24 p.

McAda, D.P., and Wasiolek, Maryann, 1988, Simulation of the regional geohydrology of the Tesuque aquifer system near Santa Fe, New Mexico: U.S. Geological Survey WaterResources Investigations Report 87-4056, 71 p. 


\section{REFERENCES-Concluded}

McDonald, M.G., and Harbaugh, A.W., 1988, A modular three-dimensional finite-difference ground-water flow model: Techniques of Water-Resources Investigations of the U.S. Geological Survey, book 6, chap. A1, variously paged.

Mourant, W.A., 1980, Hydrologic maps and data for Santa Fe County, New Mexico: New Mexico State Engineer Office Basic Data Report, 180 p., 2 pls.

Purtymun, W.D., 1984, Hydrologic characteristics of the main aquifer in the Los Alamos area; Development of ground-water supplies: Los Alamos National Laboratory Report LA-9957MS, $44 \mathrm{p}$.

Purtymun, W.D., 1995, Geologic and hydrologic records of observation wells, test holes, test wells, supply wells, springs, and surface water stations in the Los Alamos area: Los Alamos National Laboratory Report LA-12883-MS, 339 p.

Purtymun, W.D., and Adams, Howard, 1980, Geohydrology of Bandelier National Monument, New Mexico: Los Alamos National Laboratory Informal Report LA-8461-MS, 25 p.

Purtymun, W.D., Becker, N.M., and Maes, Max, 1985, Water supply at Los Alamos during 1983: Los Alamos National Laboratory Progress Report LA-10327-PR, 39 p.

Purtymun, W.D., and Cooper, J.B., 1969, Development of ground-water supplies on the Pajarito Plateau, Los Alamos County, New Mexico, in Geological Survey Research 1969: U.S. Geological Survey Professional Paper 650-B, p. 149-153.

Purtymun, W.D., Enyart, E.A., and McLin, S.G., 1989, Hydrologic characteristics of the Bandelier Tuff as determined through an injection well system: Los Alamos National Laboratory Report LA-11511-MS, 20 p.

Purtymun, W.D., and Johansen, Steven, 1974, General geohydrology of the Pajarito Plateau, in Guidebook to Ghost Ranch (central-northern New Mexico): New Mexico Geological Society, 25th Field Conference, p. 347-349.

Purtymun, W.D., McLin, S.G., Stoker, A.K., Maes, M.N., and Hammock, B.G., 1993, Water Supply at Los Alamos during 1990: Los Alamos National Laboratory Progress Report LA-12471-PR, $50 \mathrm{p}$.

Reiland, L.J., 1975, Estimated mean monthly and annual runoff at selected sites in the Pojoaque River drainage basin, Santa Fe County, New Mexico: U.S. Geological Survey Open-File Report 74-150, $21 \mathrm{p}$.

Reiland, L.J., and Koopman, F.C., 1975, Estimated availability of surface and ground water in the Pojoaque River drainage basin, Santa Fe County, New Mexico: U.S. Geological Survey Open-File Report 74-151, $35 \mathrm{p}$.

Sorensen, E.F., 1977, Water use by categories in New Mexico counties and river basins, and irrigated and dry cropland acreage in 1975: New Mexico State Engineer Technical Report 41, $34 \mathrm{p}$.

Spiegel, Zane, and Baldwin, Brewster, 1963, Geology and water resources of the Santa Fe area, New Mexico: U.S. Geological Survey Water-Supply Paper 1525, 258 p.

Stoker, A.K., McLin, S.G., Purtymun, W.D., Maes, M.N., and Hammock, B.G., 1992, Water supply at Los Alamos during 1989: Los Alamos National Laboratory Progress Report LA-12276-PR, $51 \mathrm{p}$.

Trauger, F.D., 1967, Hydrology and general geology of the Pojoaque area, Santa Fe County, New Mexico: U.S. Geological Survey Open-File Report, 32 p. 
SUPPLEMENTAL INFORMATION 
Table 5.--Constant-flow-boundary recharge rates, in cubic feet

per second

[Recharge: negative value represents discharge]

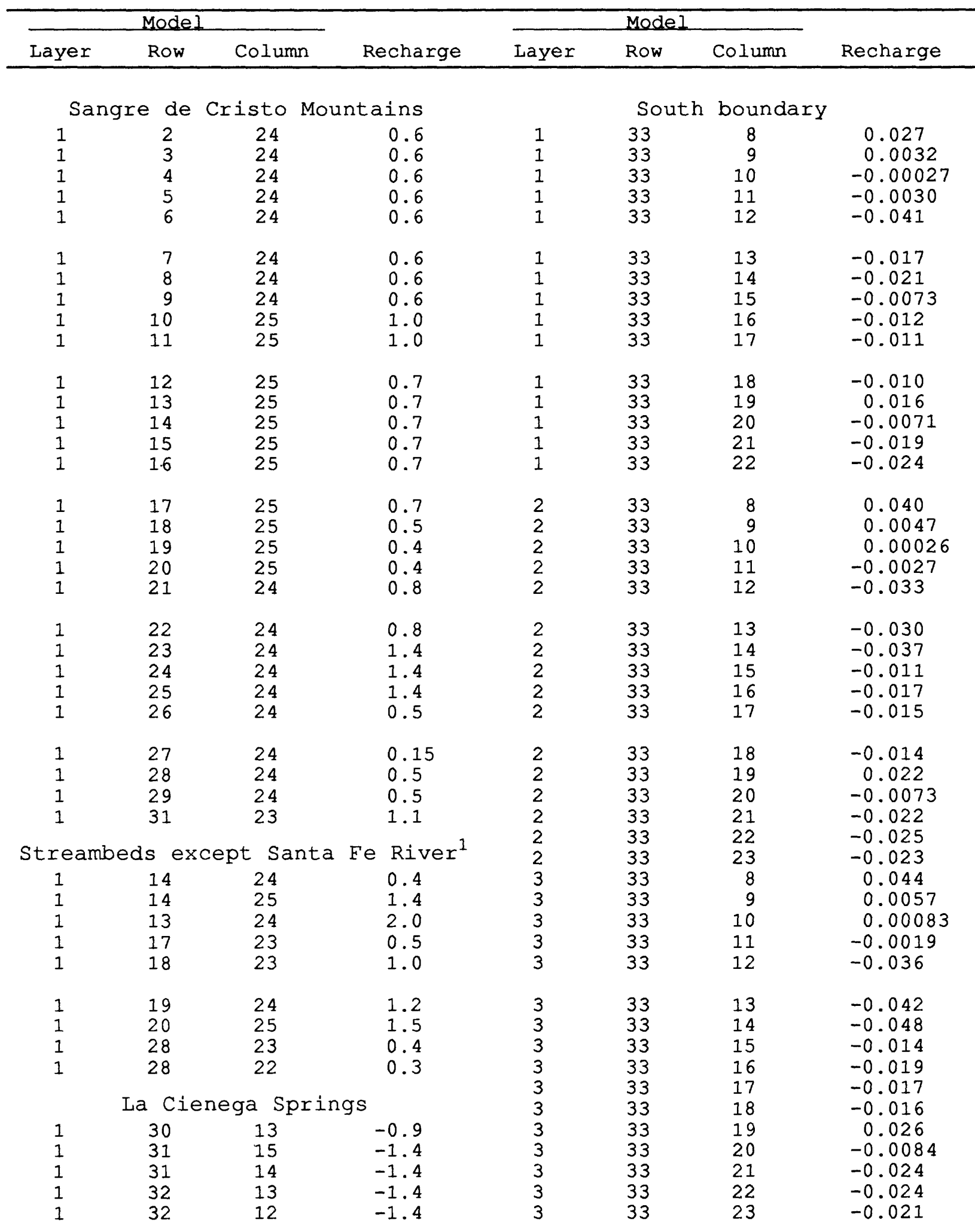


Table 5.--Constant-flow-boundary recharge rates, in cubic feet per second-Concluded

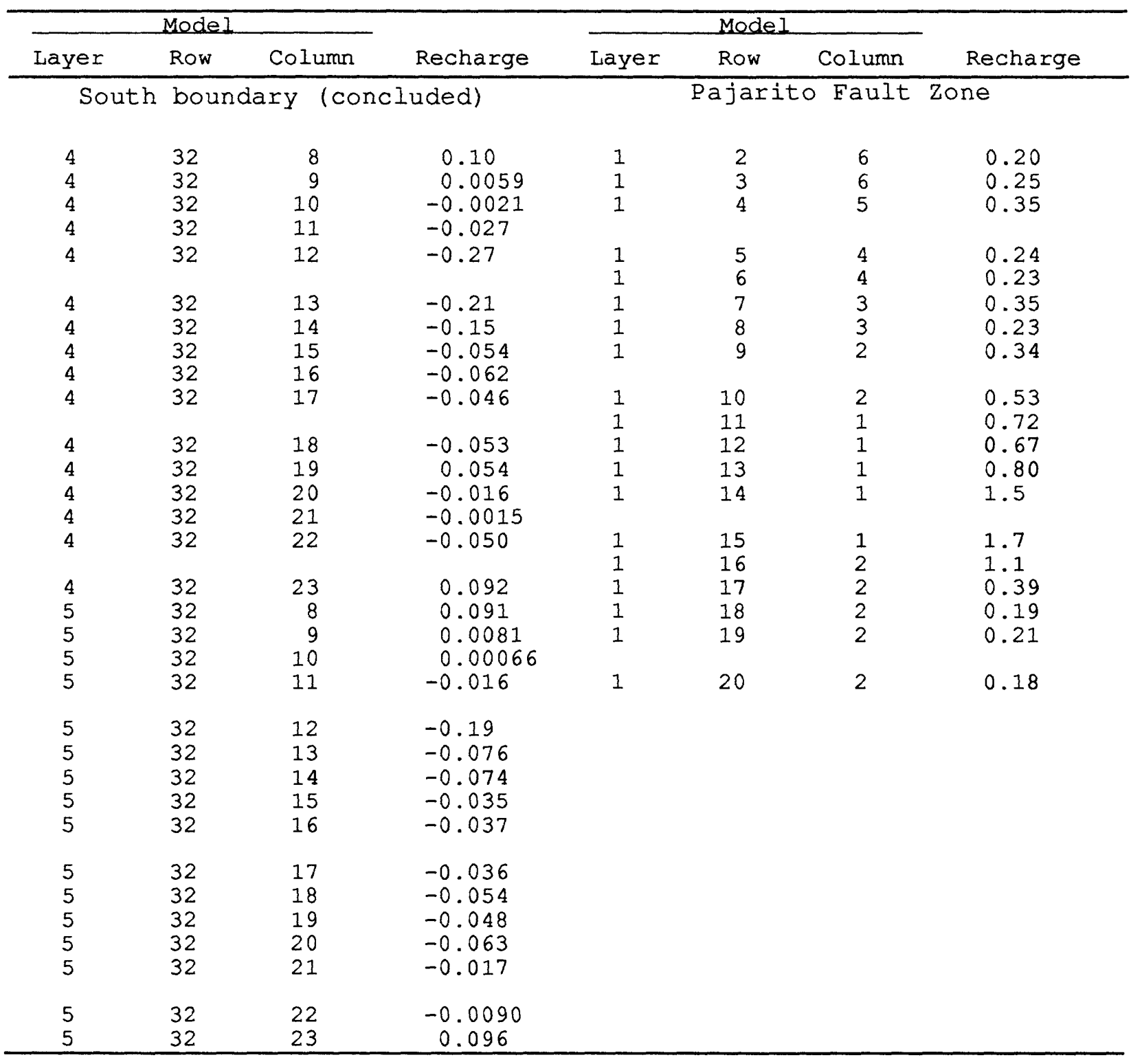

${ }^{1}$ Flow rates for Santa Fe River, variable, are reported elsewhere. 
Table 6.--Specified discharge from Los Alamos wells, in cubic feet per second

[Well locations shown in figure 2]

\begin{tabular}{|c|c|c|c|c|c|c|c|c|c|}
\hline \multirow{2}{*}{\multicolumn{2}{|c|}{$\begin{array}{c}\text { Stress } \\
\text { period and } \\
\text { year }\end{array}$}} & \multicolumn{7}{|c|}{ We II name } & \multirow[b]{2}{*}{ Sum } \\
\hline & & $L A-1 B$ & LA - 1 & $L A-2$ & $L A-3$ & $L A-4$ & $L A-5$ & LA -6 & \\
\hline 1 & 1947 & 0.0 & -0.229 & -0.117 & -0.275 & 0.0 & 0.0 & 0.0 & -0.621 \\
\hline 2 & 1948 & 0.0 & -0.147 & -0.251 & -0.350 & -0.182 & -0.172 & -0.022 & -1.124 \\
\hline 3 & 1949 & 0.0 & -0.113 & -0.177 & -0.177 & -0.160 & -0.248 & -0.406 & -1.281 \\
\hline 4 & 1950 & 0.0 & -0.045 & -0.066 & -0.245 & -0.700 & -0.552 & -0.712 & -2.320 \\
\hline 5 & 1951 & 0.0 & -0.062 & -0.245 & -0.284 & -0.736 & -0.794 & -0.856 & -2.977 \\
\hline 6 & 1952 & 0.0 & -0.014 & -0.196 & -0.248 & -0.508 & -0.466 & -0.468 & -1.900 \\
\hline 7 & 1953 & 0.0 & 0.0 & -0.200 & -0.295 & -0.462 & -0.440 & -0.482 & -1.879 \\
\hline 8 & 1954 & 0.0 & 0.0 & -0.241 & -0.243 & -0.332 & -0.340 & -0.454 & -1.610 \\
\hline 9 & 1955 & 0.0 & -0.041 & -0.209 & -0.206 & -0.402 & -0.412 & -0.458 & -1.728 \\
\hline 10 & 1956 & 0.0 & 0.0 & -0.187 & -0.178 & -0.510 & -0.444 & -0.534 & -1.853 \\
\hline 11 & 1957 & 0.0 & 0.0 & -0.125 & -0.111 & -0.448 & -0.366 & -0.434 & -1.484 \\
\hline 12 & 1958 & 0.0 & 0.0 & -0.132 & -0.142 & -0.468 & -0.382 & -0.454 & -1.578 \\
\hline 13 & 1959 & 0.0 & 0.0 & -0.173 & -0.148 & -0.482 & -0.396 & -0.460 & -1.659 \\
\hline 14 & 1960 & -0.154 & 0.0 & -0.219 & -0.163 & -0.618 & -0.506 & -0.588 & -2.248 \\
\hline 15 & 1961 & -0.530 & 0.0 & -0.188 & -0.147 & -0.550 & -0.426 & -0.478 & -2.319 \\
\hline 16 & 1962 & -0.548 & 0.0 & -0.151 & -0.192 & -0.548 & -0.458 & -0.550 & -2.447 \\
\hline 17 & 1963 & -0.498 & 0.0 & -0.173 & -0.180 & -0.554 & -0.446 & -0.436 & -2.287 \\
\hline 18 & 1964 & -0.552 & 0.0 & -0.145 & -0.214 & -0.658 & -0.504 & -0.586 & -2.659 \\
\hline 19 & 1965 & -0.416 & 0.0 & -0.169 & -0.184 & -0.472 & -0.214 & -0.440 & -1.895 \\
\hline 20 & 1966 & -0.356 & 0.0 & -0.091 & -0.195 & -0.490 & -0.336 & -0.442 & -1.910 \\
\hline 21 & 1967 & -0.360 & 0.0 & -0.021 & -0.201 & -0.328 & -0.312 & -0.362 & -1.584 \\
\hline 22 & 1968 & -0.314 & 0.0 & -0.048 & -0.181 & -0.346 & -0.268 & -0.304 & -1.461 \\
\hline 23 & 1969 & -0.322 & 0.0 & -0.016 & -0.170 & -0.262 & -0.290 & -0.346 & -1.406 \\
\hline 24 & 1970 & -0.338 & 0.0 & -0.031 & -0.187 & -0.354 & -0.280 & -0.336 & -1.526 \\
\hline 25 & 1971 & -0.378 & 0.0 & -0.135 & -0.192 & -0.378 & -0.316 & -0.350 & -1.749 \\
\hline 26 & 1972 & -0.320 & 0.0 & -0.167 & -0.168 & -0.350 & -0.274 & -0.336 & -1.615 \\
\hline 27 & 1973 & -0.370 & 0.0 & -0.198 & -0.086 & -0.392 & -0.290 & -0.384 & -1.720 \\
\hline 28 & 1974 & -0.314 & 0.0 & -0.156 & -0.184 & -0.348 & -0.224 & -0.338 & -1.564 \\
\hline 29 & 1975 & -0.316 & 0.0 & -0.170 & -0.184 & -0.350 & -0.272 & -0.220 & -1.512 \\
\hline 30 & 1976 & -0.338 & 0.0 & -0.169 & -0.179 & -0.416 & -0.330 & -0.022 & -1.454 \\
\hline 31 & 1977 & -0.358 & 0.0 & -0.180 & -0.201 & -0.410 & -0.318 & 0.0 & -1.467 \\
\hline 32 & 1978 & -0.320 & 0.0 & -0.167 & -0.180 & -0.340 & -0.276 & -0.006 & -1.289 \\
\hline 33 & 1979 & -0.196 & 0.0 & -0.111 & -0.119 & -0.444 & -0.356 & -0.002 & -1.228 \\
\hline 34 & 1980 & -0.268 & 0.0 & -0.143 & -0.149 & -0.490 & -0.392 & 0.0 & -1.442 \\
\hline 35 & 1981 & -0.314 & 0.0 & -0.146 & -0.176 & -0.380 & -0.410 & 0.0 & -1.426 \\
\hline 36 & 1982 & -0.458 & 0.0 & -0.217 & -0.233 & 0.0 & -0.434 & 0.0 & -1.342 \\
\hline 37 & 1983 & -0.051 & 0.0 & -0.231 & -0.062 & -0.261 & -0.331 & 0.0 & -0.936 \\
\hline 38 & 1984 & -0.410 & 0.0 & -0.227 & -0.070 & -0.369 & -0.305 & 0.0 & -1.381 \\
\hline 39 & 1985 & -0.290 & 0.0 & -0.157 & -0.177 & -0.366 & -0.236 & 0.0 & -1.226 \\
\hline 40 & 1986 & -0.233 & 0.0 & -0.102 & -0.114 & -0.164 & -0.147 & 0.0 & -0.760 \\
\hline
\end{tabular}


Table 6.--Specified discharge from Los Alamos wells, in cubic feet per second --Concluded

\begin{tabular}{|c|c|c|c|c|c|c|c|c|c|}
\hline \multirow{2}{*}{\multicolumn{2}{|c|}{$\begin{array}{c}\text { Stress } \\
\text { period and } \\
\text { year }\end{array}$}} & \multicolumn{7}{|c|}{ Wel1 name } & \multirow[b]{2}{*}{ Sum } \\
\hline & & $L A-1 B$ & $L A-1$ & $\mathrm{LA}-2$ & $L A-3$ & $L A-4$ & $L A-5$ & $L A-6$ & \\
\hline 41 & 1987 & -0.412 & 0.0 & -0.168 & -0.216 & -0.007 & -0.118 & 0.0 & -0.921 \\
\hline 42 & 1988 & -0.319 & 0.0 & -0.140 & -0.170 & 0.0 & -0.042 & 0.0 & -0.671 \\
\hline 43 & 1989 & -0.414 & 0.0 & -0.183 & -0.220 & 0.0 & -0.112 & 0.0 & -0.929 \\
\hline 44 & 1990 & -0.291 & 0.0 & -0.171 & -0.189 & 0.0 & -0.141 & 0.0 & -0.792 \\
\hline 45 & 1991 & -0.213 & 0.0 & -0.139 & -0.099 & 0.0 & -0.078 & 0.0 & -0.529 \\
\hline 46 & 1992 & 0.0 & 0.0 & -0.057 & 0.0 & 0.0 & 0.0 & 0.0 & -0.057 \\
\hline 47 & $1993-2013$ & 0.0 & 0.0 & 0.0 & 0.0 & 0.0 & 0.0 & 0.0 & 0.0 \\
\hline
\end{tabular}




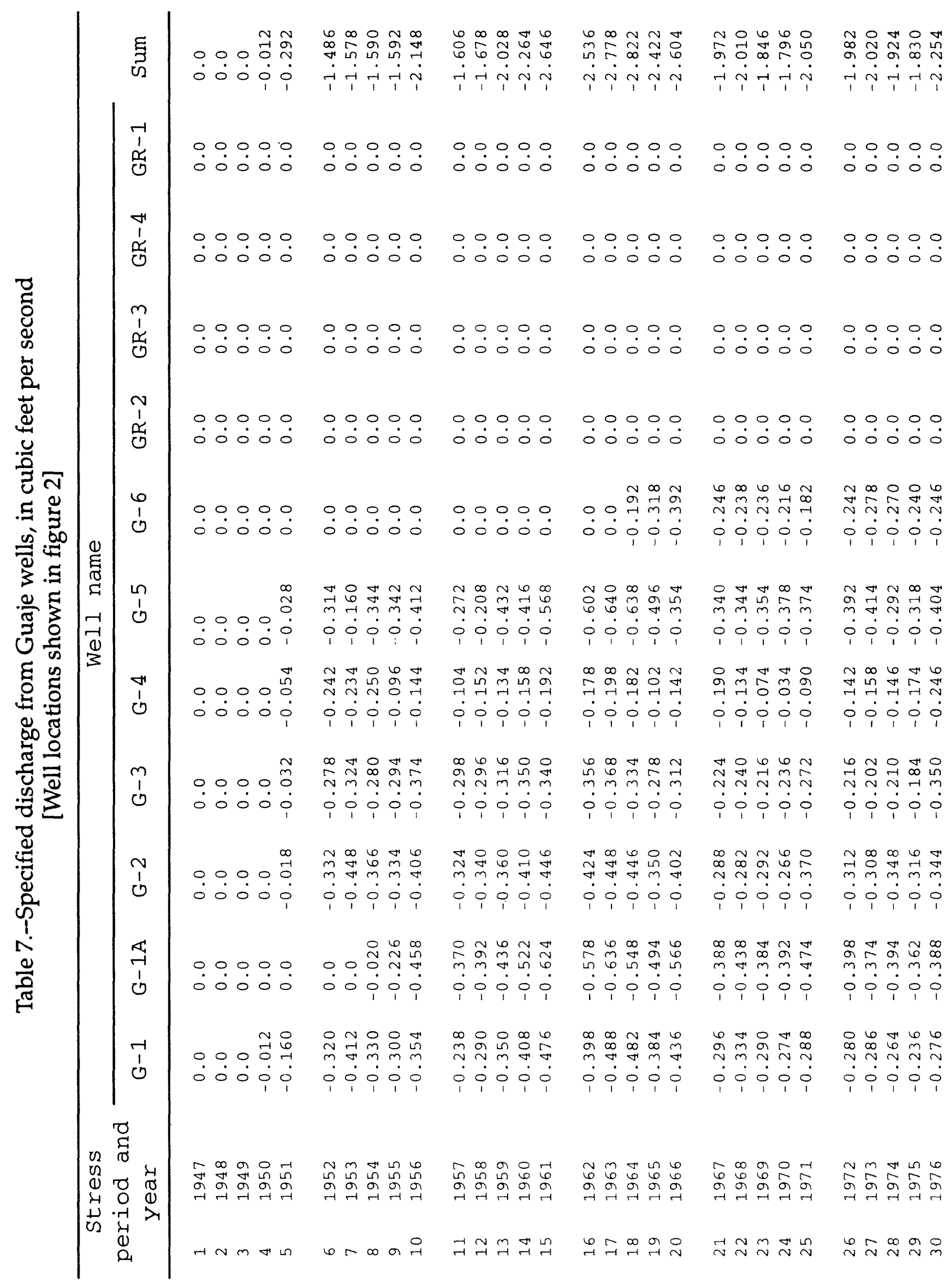




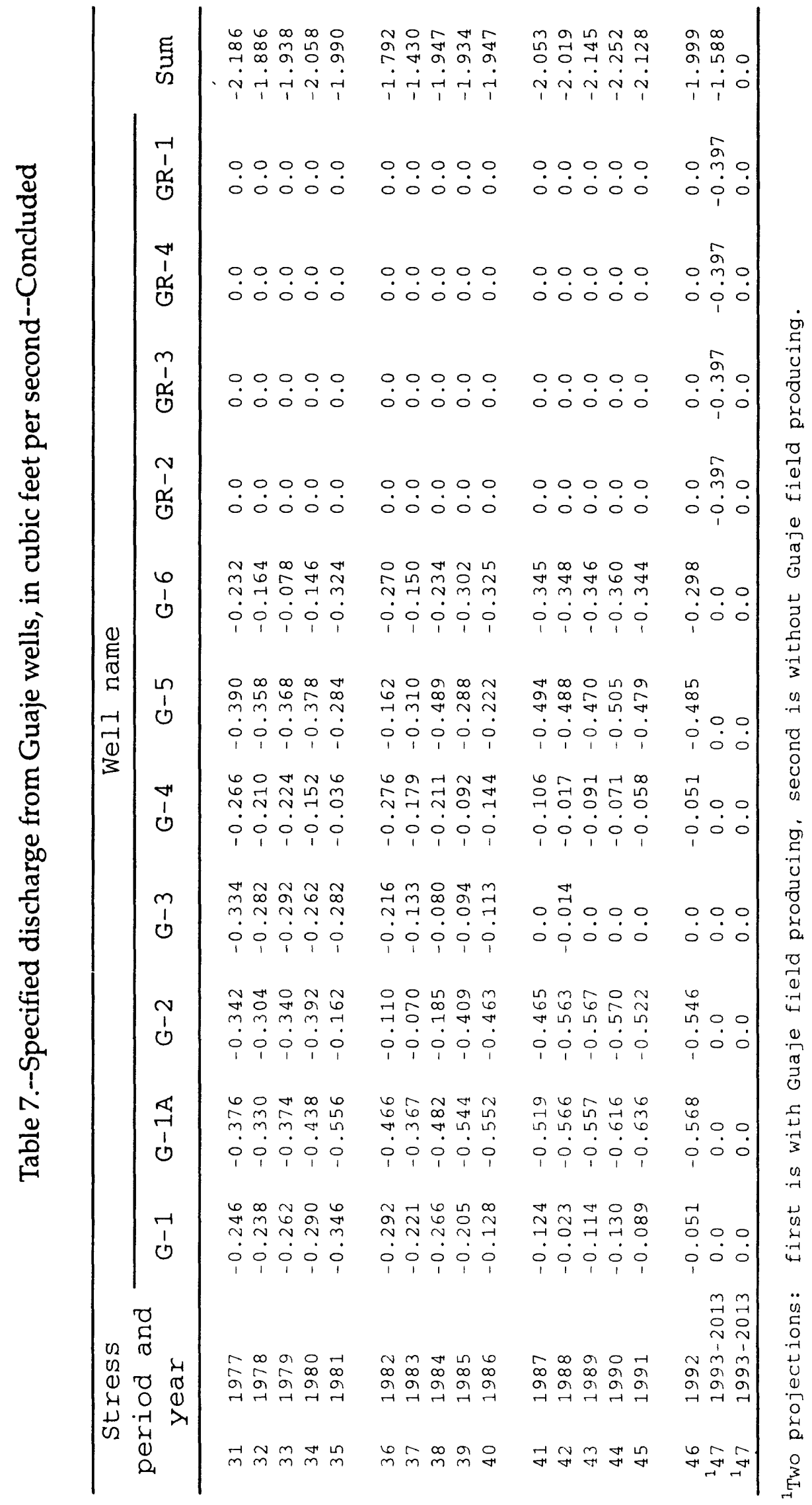


Table 8.--Specified discharge from Pajarito Mesa and Otowi wells, in cubic feet per second

[Well locations shown in figure 2]

\begin{tabular}{|c|c|c|c|c|c|c|c|c|c|}
\hline \multirow{2}{*}{\multicolumn{2}{|c|}{$\begin{array}{l}\text { Stress period and } \\
\text { year }\end{array}$}} & \multicolumn{7}{|c|}{ Well name } & \multirow[b]{2}{*}{ Sum } \\
\hline & & $\overline{\mathrm{PM}-1}$ & $\overline{\mathrm{PM}-1}$ & PM-3 & $\overline{P M-4}$ & PM-5 & $\overline{\mathrm{O}-1}$ & $\bar{O}-4$ & \\
\hline $\begin{array}{l}1 \\
2 \\
3 \\
4 \\
5\end{array}$ & $\begin{array}{l}1947 \\
1948 \\
1949 \\
1950 \\
1951\end{array}$ & $\begin{array}{l}0.0 \\
0.0 \\
0.0 \\
0.0 \\
0.0\end{array}$ & $\begin{array}{l}0.0 \\
0.0 \\
0.0 \\
0.0 \\
0.0\end{array}$ & $\begin{array}{l}0.0 \\
0.0 \\
0.0 \\
0.0 \\
0.0\end{array}$ & $\begin{array}{l}0.0 \\
0.0 \\
0.0 \\
0.0 \\
0.0\end{array}$ & $\begin{array}{l}0.0 \\
0.0 \\
0.0 \\
0.0 \\
0.0\end{array}$ & $\begin{array}{l}0.0 \\
0.0 \\
0.0 \\
0.0 \\
0.0\end{array}$ & $\begin{array}{l}0.0 \\
0.0 \\
0.0 \\
0.0 \\
0.0\end{array}$ & $\begin{array}{l}0.0 \\
0.0 \\
0.0 \\
0.0 \\
0.0\end{array}$ \\
\hline $\begin{array}{l}6 \\
7 \\
8 \\
9 \\
10\end{array}$ & $\begin{array}{l}1952 \\
1953 \\
1954 \\
1955 \\
1956\end{array}$ & $\begin{array}{l}0.0 \\
0.0 \\
0.0 \\
0.0 \\
0.0\end{array}$ & $\begin{array}{l}0.0 \\
0.0 \\
0.0 \\
0.0 \\
0.0\end{array}$ & $\begin{array}{l}0.0 \\
0.0 \\
0.0 \\
0.0 \\
0.0\end{array}$ & $\begin{array}{l}0.0 \\
0.0 \\
0.0 \\
0.0 \\
0.0\end{array}$ & $\begin{array}{l}0.0 \\
0.0 \\
0.0 \\
0.0 \\
0.0\end{array}$ & $\begin{array}{l}0.0 \\
0.0 \\
0.0 \\
0.0 \\
0.0\end{array}$ & $\begin{array}{l}0.0 \\
0.0 \\
0.0 \\
0.0 \\
0.0\end{array}$ & $\begin{array}{l}0.0 \\
0.0 \\
0.0 \\
0.0 \\
0.0\end{array}$ \\
\hline $\begin{array}{l}11 \\
12 \\
13 \\
14 \\
15\end{array}$ & $\begin{array}{l}1957 \\
1958 \\
1959 \\
1960 \\
1961\end{array}$ & $\begin{array}{l}0.0 \\
0.0 \\
0.0 \\
0.0 \\
0.0\end{array}$ & $\begin{array}{l}0.0 \\
0.0 \\
0.0 \\
0.0 \\
0.0\end{array}$ & $\begin{array}{l}0.0 \\
0.0 \\
0.0 \\
0.0 \\
0.0\end{array}$ & $\begin{array}{l}0.0 \\
0.0 \\
0.0 \\
0.0 \\
0.0\end{array}$ & $\begin{array}{l}0.0 \\
0.0 \\
0.0 \\
0.0 \\
0.0\end{array}$ & $\begin{array}{l}0.0 \\
0.0 \\
0.0 \\
0.0 \\
0.0\end{array}$ & $\begin{array}{l}0.0 \\
0.0 \\
0.0 \\
0.0 \\
0.0\end{array}$ & $\begin{array}{l}0.0 \\
0.0 \\
0.0 \\
0.0 \\
0.0\end{array}$ \\
\hline $\begin{array}{l}16 \\
17 \\
18 \\
19 \\
20\end{array}$ & $\begin{array}{l}1962 \\
1963 \\
1964 \\
1965 \\
1966\end{array}$ & $\begin{array}{l}0.0 \\
0.0 \\
0.0 \\
-0.422 \\
-0.458\end{array}$ & $\begin{array}{l}0.0 \\
0.0 \\
0.0 \\
0.0 \\
-0.080\end{array}$ & $\begin{array}{l}0.0 \\
0.0 \\
0.0 \\
0.0 \\
0.0\end{array}$ & $\begin{array}{l}0.0 \\
0.0 \\
0.0 \\
0.0 \\
0.0\end{array}$ & $\begin{array}{l}0.0 \\
0.0 \\
0.0 \\
0.0 \\
0.0\end{array}$ & $\begin{array}{l}0.0 \\
0.0 \\
0.0 \\
0.0 \\
0.0\end{array}$ & $\begin{array}{l}0.0 \\
0.0 \\
0.0 \\
0.0 \\
0.0\end{array}$ & $\begin{array}{l}0.0 \\
0.0 \\
0.0 \\
-0.422 \\
-0.538\end{array}$ \\
\hline $\begin{array}{l}21 \\
22 \\
23 \\
24 \\
25\end{array}$ & $\begin{array}{l}1967 \\
1968 \\
1969 \\
1970 \\
1971\end{array}$ & $\begin{array}{l}-0.472 \\
-0.290 \\
-0.146 \\
-0.282 \\
-0.428\end{array}$ & $\begin{array}{l}-1.568 \\
-1.392 \\
-1.186 \\
-1.274 \\
-1.440\end{array}$ & $\begin{array}{l}0.0 \\
-0.794 \\
-1.080 \\
-0.966 \\
-0.918\end{array}$ & $\begin{array}{l}0.0 \\
0.0 \\
0.0 \\
0.0 \\
0.0\end{array}$ & $\begin{array}{l}0.0 \\
0.0 \\
0.0 \\
0.0 \\
0.0\end{array}$ & $\begin{array}{l}0.0 \\
0.0 \\
0.0 \\
0.0 \\
0.0\end{array}$ & $\begin{array}{l}0.0 \\
0.0 \\
0.0 \\
0.0 \\
0.0\end{array}$ & $\begin{array}{l}-2.040 \\
-2.476 \\
-2.412 \\
-2.522 \\
-2.786\end{array}$ \\
\hline $\begin{array}{l}26 \\
27 \\
28 \\
29 \\
30\end{array}$ & $\begin{array}{l}1972 \\
1973 \\
1974 \\
1975 \\
1976\end{array}$ & $\begin{array}{l}-0.360 \\
-0.198 \\
-0.408 \\
-0.402 \\
-0.454\end{array}$ & $\begin{array}{l}-1.634 \\
-1.614 \\
-1.912 \\
-1.634 \\
-1.874\end{array}$ & $\begin{array}{l}-0.814 \\
-1.094 \\
-1.082 \\
-1.142 \\
-1.138\end{array}$ & $\begin{array}{l}0.0 \\
0.0 \\
0.0 \\
0.0 \\
0.0\end{array}$ & $\begin{array}{l}0.0 \\
0.0 \\
0.0 \\
0.0 \\
0.0\end{array}$ & $\begin{array}{l}0.0 \\
0.0 \\
0.0 \\
0.0 \\
0.0\end{array}$ & $\begin{array}{l}0.0 \\
0.0 \\
0.0 \\
0.0 \\
0.0\end{array}$ & $\begin{array}{l}-2.808 \\
-2.906 \\
-3.402 \\
-3.178 \\
-3.466\end{array}$ \\
\hline $\begin{array}{l}31 \\
32 \\
33 \\
34 \\
35\end{array}$ & $\begin{array}{l}1977 \\
1978 \\
1979 \\
1980 \\
1981\end{array}$ & $\begin{array}{l}-0.448 \\
-0.384 \\
-0.354 \\
-0.418 \\
-0.418\end{array}$ & $\begin{array}{l}-1.156 \\
-1.646 \\
-1.618 \\
-1.736 \\
-1.570\end{array}$ & $\begin{array}{l}-0.998 \\
-0.894 \\
-0.836 \\
-0.994 \\
-0.986\end{array}$ & $\begin{array}{l}0.0 \\
0.0 \\
0.0 \\
0.0 \\
0.0\end{array}$ & $\begin{array}{l}0.0 \\
0.0 \\
0.0 \\
0.0 \\
0.0\end{array}$ & $\begin{array}{l}0.0 \\
0.0 \\
0.0 \\
0.0 \\
0.0\end{array}$ & $\begin{array}{l}0.0 \\
0.0 \\
0.0 \\
0.0 \\
0.0\end{array}$ & $\begin{array}{l}-2.602 \\
-2.924 \\
-2.808 \\
-3.148 \\
-2.974\end{array}$ \\
\hline $\begin{array}{l}36 \\
37 \\
38 \\
39 \\
40\end{array}$ & $\begin{array}{l}1982 \\
1983 \\
1984 \\
1985 \\
1986\end{array}$ & $\begin{array}{l}-0.422 \\
-0.366 \\
-0.393 \\
-0.404 \\
-0.313\end{array}$ & $\begin{array}{l}-1.524 \\
-0.669 \\
-0.346 \\
-0.607 \\
-0.358\end{array}$ & $\begin{array}{l}-1.010 \\
-0.879 \\
-1.167 \\
-0.937 \\
-1.037\end{array}$ & $\begin{array}{l}0.0 \\
-1.917 \\
-1.380 \\
-1.606 \\
-1.302\end{array}$ & $\begin{array}{l}0.0 \\
0.0 \\
0.0 \\
-0.008 \\
-0.624\end{array}$ & $\begin{array}{l}0.0 \\
0.0 \\
0.0 \\
0.0 \\
0.0\end{array}$ & $\begin{array}{l}0.0 \\
0.0 \\
0.0 \\
0.0 \\
0.0\end{array}$ & $\begin{array}{l}-2.956 \\
-3.831 \\
-3.286 \\
-3.562 \\
-3.634\end{array}$ \\
\hline $\begin{array}{l}41 \\
42 \\
43 \\
44 \\
45\end{array}$ & $\begin{array}{l}1987 \\
1988 \\
1989 \\
1990 \\
1991\end{array}$ & $\begin{array}{l}-0.434 \\
-0.415 \\
-0.444 \\
-0.374 \\
-0.375\end{array}$ & $\begin{array}{l}-0.120 \\
-0.622 \\
-0.551 \\
-1.061 \\
-0.723\end{array}$ & $\begin{array}{l}-1.060 \\
-0.983 \\
-0.936 \\
-1.036 \\
-0.972\end{array}$ & $\begin{array}{l}-1.661 \\
-0.926 \\
-1.774 \\
-0.929 \\
-0.930\end{array}$ & $\begin{array}{l}-0.502 \\
-0.545 \\
-0.365 \\
-0.513 \\
-0.475\end{array}$ & $\begin{array}{l}0.0 \\
0.0 \\
0.0 \\
0.0 \\
0.0\end{array}$ & $\begin{array}{l}0.0 \\
0.0 \\
0.0 \\
0.0 \\
0.0\end{array}$ & $\begin{array}{l}-3.777 \\
-3.491 \\
-4.070 \\
-3.913 \\
-3.475\end{array}$ \\
\hline $\begin{array}{l}46 \\
147 \\
147 \\
\end{array}$ & $\begin{array}{l}1992 \\
1993-2013 \\
1993-2013\end{array}$ & $\begin{array}{l}-0.393 \\
-0.282 \\
-0.378\end{array}$ & $\begin{array}{l}-1.176 \\
-0.844 \\
-1.131 \\
\end{array}$ & $\begin{array}{l}-1.302 \\
-0.935 \\
-1.253 \\
\end{array}$ & $\begin{array}{l}-0.671 \\
-0.482 \\
-0.646\end{array}$ & $\begin{array}{l}-0.883 \\
-0.634 \\
-0.850\end{array}$ & $\begin{array}{l}0.0 \\
-0.397 \\
-0.699\end{array}$ & $\begin{array}{l}0.0 \\
-1.191 \\
-1.398 \\
\end{array}$ & $\begin{array}{l}-4.425 \\
-4.765 \\
-6.355 \\
\end{array}$ \\
\hline
\end{tabular}

${ }^{1}$ Two projections: first is with Guaje field producing, second is without Guaje field producing. 
Table 9.-Specified discharge from Buckman wells, in cubic feet per second [Well locations shown in figure 2]

\begin{tabular}{|c|c|c|c|c|c|c|c|c|c|c|}
\hline & Stress & & & & We & name & & & & \\
\hline & year & $B-1$ & $B-2$ & $B-3$ & $B-4$ & $B-5$ & $B-6$ & $B-7$ & $B-8$ & Sum \\
\hline $\begin{array}{l}1 \\
2 \\
3 \\
4 \\
5\end{array}$ & $\begin{array}{l}1947 \\
1948 \\
1949 \\
1950 \\
1951\end{array}$ & $\begin{array}{l}0.0 \\
0.0 \\
0.0 \\
0.0 \\
0.0\end{array}$ & $\begin{array}{l}0.0 \\
0.0 \\
0.0 \\
0.0 \\
0.0\end{array}$ & $\begin{array}{l}0.0 \\
0.0 \\
0.0 \\
0.0 \\
0.0\end{array}$ & $\begin{array}{l}0.0 \\
0.0 \\
0.0 \\
0.0 \\
0.0\end{array}$ & $\begin{array}{l}0.0 \\
0.0 \\
0.0 \\
0.0 \\
0.0\end{array}$ & $\begin{array}{l}0.0 \\
0.0 \\
0.0 \\
0.0 \\
0.0\end{array}$ & $\begin{array}{l}0.0 \\
0.0 \\
0.0 \\
0.0 \\
0.0\end{array}$ & $\begin{array}{l}0.0 \\
0.0 \\
0.0 \\
0.0 \\
0.0\end{array}$ & $\begin{array}{l}0.0 \\
0.0 \\
0.0 \\
0.0 \\
0.0\end{array}$ \\
\hline $\begin{array}{l}6 \\
7 \\
8 \\
9 \\
10\end{array}$ & $\begin{array}{l}1952 \\
1953 \\
1954 \\
1955 \\
1956\end{array}$ & $\begin{array}{l}0.0 \\
0.0 \\
0.0 \\
0.0 \\
0.0\end{array}$ & $\begin{array}{l}0.0 \\
0.0 \\
0.0 \\
0.0 \\
0.0\end{array}$ & $\begin{array}{l}0.0 \\
0.0 \\
0.0 \\
0.0 \\
0.0\end{array}$ & $\begin{array}{l}0.0 \\
0.0 \\
0.0 \\
0.0 \\
0.0\end{array}$ & $\begin{array}{l}0.0 \\
0.0 \\
0.0 \\
0.0 \\
0.0\end{array}$ & $\begin{array}{l}0.0 \\
0.0 \\
0.0 \\
0.0 \\
0.0\end{array}$ & $\begin{array}{l}0.0 \\
0.0 \\
0.0 \\
0.0 \\
0.0\end{array}$ & $\begin{array}{l}0.0 \\
0.0 \\
0.0 \\
0.0 \\
0.0\end{array}$ & $\begin{array}{l}0.0 \\
0.0 \\
0.0 \\
0.0 \\
0.0\end{array}$ \\
\hline $\begin{array}{l}11 \\
12 \\
13 \\
14 \\
15\end{array}$ & $\begin{array}{l}1957 \\
1958 \\
1959 \\
1960 \\
1961\end{array}$ & $\begin{array}{l}0.0 \\
0.0 \\
0.0 \\
0.0 \\
0.0\end{array}$ & $\begin{array}{l}0.0 \\
0.0 \\
0.0 \\
0.0 \\
0.0\end{array}$ & $\begin{array}{l}0.0 \\
0.0 \\
0.0 \\
0.0 \\
0.0\end{array}$ & $\begin{array}{l}0.0 \\
0.0 \\
0.0 \\
0.0 \\
0.0\end{array}$ & $\begin{array}{l}0.0 \\
0.0 \\
0.0 \\
0.0 \\
0.0\end{array}$ & $\begin{array}{l}0.0 \\
0.0 \\
0.0 \\
0.0 \\
0.0\end{array}$ & $\begin{array}{l}0.0 \\
0.0 \\
0.0 \\
0.0 \\
0.0\end{array}$ & $\begin{array}{l}0.0 \\
0.0 \\
0.0 \\
0.0 \\
0.0\end{array}$ & $\begin{array}{l}0.0 \\
0.0 \\
0.0 \\
0.0 \\
0.0\end{array}$ \\
\hline $\begin{array}{l}16 \\
17 \\
18 \\
19 \\
20\end{array}$ & $\begin{array}{l}1962 \\
1963 \\
1964 \\
1965 \\
1966\end{array}$ & $\begin{array}{l}0.0 \\
0.0 \\
0.0 \\
0.0 \\
0.0\end{array}$ & $\begin{array}{l}0.0 \\
0.0 \\
0.0 \\
0.0 \\
0.0\end{array}$ & $\begin{array}{l}0.0 \\
0.0 \\
0.0 \\
0.0 \\
0.0\end{array}$ & $\begin{array}{l}0.0 \\
0.0 \\
0.0 \\
0.0 \\
0.0\end{array}$ & $\begin{array}{l}0.0 \\
0.0 \\
0.0 \\
0.0 \\
0.0\end{array}$ & $\begin{array}{l}0.0 \\
0.0 \\
0.0 \\
0.0 \\
0.0\end{array}$ & $\begin{array}{l}0.0 \\
0.0 \\
0.0 \\
0.0 \\
0.0\end{array}$ & $\begin{array}{l}0.0 \\
0.0 \\
0.0 \\
0.0 \\
0.0\end{array}$ & $\begin{array}{l}0.0 \\
0.0 \\
0.0 \\
0.0 \\
0.0\end{array}$ \\
\hline $\begin{array}{l}21 \\
22 \\
23 \\
24 \\
25\end{array}$ & $\begin{array}{l}1967 \\
1968 \\
1969 \\
1970 \\
1971\end{array}$ & $\begin{array}{l}0.0 \\
0.0 \\
0.0 \\
0.0 \\
0.0\end{array}$ & $\begin{array}{l}0.0 \\
0.0 \\
0.0 \\
0.0 \\
0.0\end{array}$ & $\begin{array}{l}0.0 \\
0.0 \\
0.0 \\
0.0 \\
0.0\end{array}$ & $\begin{array}{l}0.0 \\
0.0 \\
0.0 \\
0.0 \\
0.0\end{array}$ & $\begin{array}{l}0.0 \\
0.0 \\
0.0 \\
0.0 \\
0.0\end{array}$ & $\begin{array}{l}0.0 \\
0.0 \\
0.0 \\
0.0 \\
0.0\end{array}$ & $\begin{array}{l}0.0 \\
0.0 \\
0.0 \\
0.0 \\
0.0\end{array}$ & $\begin{array}{l}0.0 \\
0.0 \\
0.0 \\
0.0 \\
0.0\end{array}$ & $\begin{array}{l}0.0 \\
0.0 \\
0.0 \\
0.0 \\
0.0\end{array}$ \\
\hline $\begin{array}{l}26 \\
27 \\
28 \\
29 \\
30\end{array}$ & $\begin{array}{l}1972 \\
1973 \\
1974 \\
1975 \\
1976\end{array}$ & $\begin{array}{l}0.0 \\
0.0 \\
0.0 \\
0.0 \\
0.0\end{array}$ & $\begin{array}{l}0.0 \\
0.0 \\
0.0 \\
0.0 \\
0.0\end{array}$ & $\begin{array}{l}-0.392 \\
-1.080 \\
-1.430 \\
-0.914 \\
-1.232\end{array}$ & $\begin{array}{l}-0.390 \\
-1.010 \\
-1.296 \\
-1.010 \\
-1.326\end{array}$ & $\begin{array}{l}0.0 \\
0.0 \\
-0.256 \\
-0.106 \\
-0.002\end{array}$ & $\begin{array}{l}-0.392 \\
-1.038 \\
-1.564 \\
-1.250 \\
-1.176\end{array}$ & $\begin{array}{l}0.0 \\
0.0 \\
0.0 \\
0.0 \\
0.0\end{array}$ & $\begin{array}{l}0.0 \\
0.0 \\
0.0 \\
0.0 \\
0.0\end{array}$ & $\begin{array}{l}-1.174 \\
-3.128 \\
-4.546 \\
-3.280 \\
-3.736\end{array}$ \\
\hline $\begin{array}{l}31 \\
32 \\
33 \\
34 \\
35\end{array}$ & $\begin{array}{l}1977 \\
1978 \\
1979 \\
1980 \\
1981\end{array}$ & $\begin{array}{l}0.0 \\
0.0 \\
0.0 \\
0.0 \\
0.0\end{array}$ & $\begin{array}{l}0.0 \\
0.0 \\
0.0 \\
0.0 \\
0.0\end{array}$ & $\begin{array}{l}-1.382 \\
-0.742 \\
-0.236 \\
-0.234 \\
-1.182\end{array}$ & $\begin{array}{l}-1.452 \\
-0.742 \\
-0.236 \\
-0.234 \\
-1.180\end{array}$ & $\begin{array}{l}0.0 \\
0.0 \\
-0.236 \\
0.0 \\
0.0\end{array}$ & $\begin{array}{c}-1.240 \\
-0.740 \\
0.0 \\
-0.234 \\
-1.182\end{array}$ & $\begin{array}{l}0.0 \\
0.0 \\
0.0 \\
0.0 \\
0.0\end{array}$ & $\begin{array}{l}0.0 \\
0.0 \\
0.0 \\
0.0 \\
0.0\end{array}$ & $\begin{array}{l}-4.074 \\
-2.224 \\
-0.708 \\
-0.702 \\
-3.544\end{array}$ \\
\hline $\begin{array}{l}36 \\
37 \\
38 \\
39 \\
40\end{array}$ & $\begin{array}{l}1982 \\
1983 \\
1984 \\
1985 \\
1986\end{array}$ & $\begin{array}{l}0.0 \\
-0.007 \\
-0.128 \\
-0.575 \\
-0.777\end{array}$ & $\begin{array}{l}0.0 \\
-0.008 \\
-0.270 \\
-0.841 \\
-1.219\end{array}$ & $\begin{array}{l}-0.574 \\
-0.002 \\
0.0 \\
0.0 \\
0.0\end{array}$ & $\begin{array}{l}-0.574 \\
0.0 \\
0.0 \\
0.0 \\
0.0\end{array}$ & $\begin{array}{l}0.0 \\
0.0 \\
0.0 \\
0.0 \\
0.0\end{array}$ & $\begin{array}{l}-0.574 \\
0.0 \\
0.0 \\
0.0 \\
0.0\end{array}$ & $\begin{array}{l}0.0 \\
0.0 \\
0.0 \\
0.0 \\
0.0\end{array}$ & $\begin{array}{l}0.0 \\
0.0 \\
0.0 \\
0.0 \\
0.0\end{array}$ & $\begin{array}{l}-1.722 \\
-0.017 \\
-0.398 \\
-1.416 \\
-1.996\end{array}$ \\
\hline $\begin{array}{l}41 \\
42 \\
43 \\
44 \\
45\end{array}$ & $\begin{array}{l}1987 \\
1988 \\
1989 \\
1990 \\
1991\end{array}$ & $\begin{array}{l}-0.720 \\
-0.436 \\
-0.657 \\
-0.392 \\
-0.222\end{array}$ & $\begin{array}{l}-1.127 \\
-0.974 \\
-1.487 \\
-0.980 \\
-0.611\end{array}$ & $\begin{array}{l}0.0 \\
-0.203 \\
-0.308 \\
-0.307 \\
-0.207\end{array}$ & $\begin{array}{l}0.0 \\
-0.707 \\
-1.220 \\
-1.204 \\
-0.734\end{array}$ & $\begin{array}{l}0.0 \\
-0.102 \\
-0.173 \\
-0.169 \\
-0.112\end{array}$ & $\begin{array}{l}0.0 \\
-0.940 \\
-1.463 \\
-1.387 \\
-0.914\end{array}$ & $\begin{array}{l}0.0 \\
0.0 \\
0.0 \\
0.0 \\
-0.349\end{array}$ & $\begin{array}{l}0.0 \\
0.0 \\
0.0 \\
0.0 \\
-0.439\end{array}$ & $\begin{array}{l}-1.847 \\
-3.362 \\
-5.308 \\
-4.439 \\
-3.588\end{array}$ \\
\hline $\begin{array}{l}46 \\
47 \\
\end{array}$ & $\begin{array}{l}1992 \\
1993-2013 \\
\end{array}$ & $\begin{array}{l}-0.104 \\
-0.104 \\
\end{array}$ & $\begin{array}{l}-0.471 \\
-0.471 \\
\end{array}$ & $\begin{array}{l}-0.083 \\
-0.083 \\
\end{array}$ & $\begin{array}{l}-0.299 \\
-0.299 \\
\end{array}$ & $\begin{array}{l}-0.019 \\
-0.019 \\
\end{array}$ & $\begin{array}{l}-0.887 \\
-0.887 \\
\end{array}$ & $\begin{array}{l}-0.728 \\
-0.728 \\
\end{array}$ & $\begin{array}{l}-0.734 \\
-0.734 \\
\end{array}$ & $\begin{array}{l}-3.325 \\
-3.325 \\
\end{array}$ \\
\hline
\end{tabular}




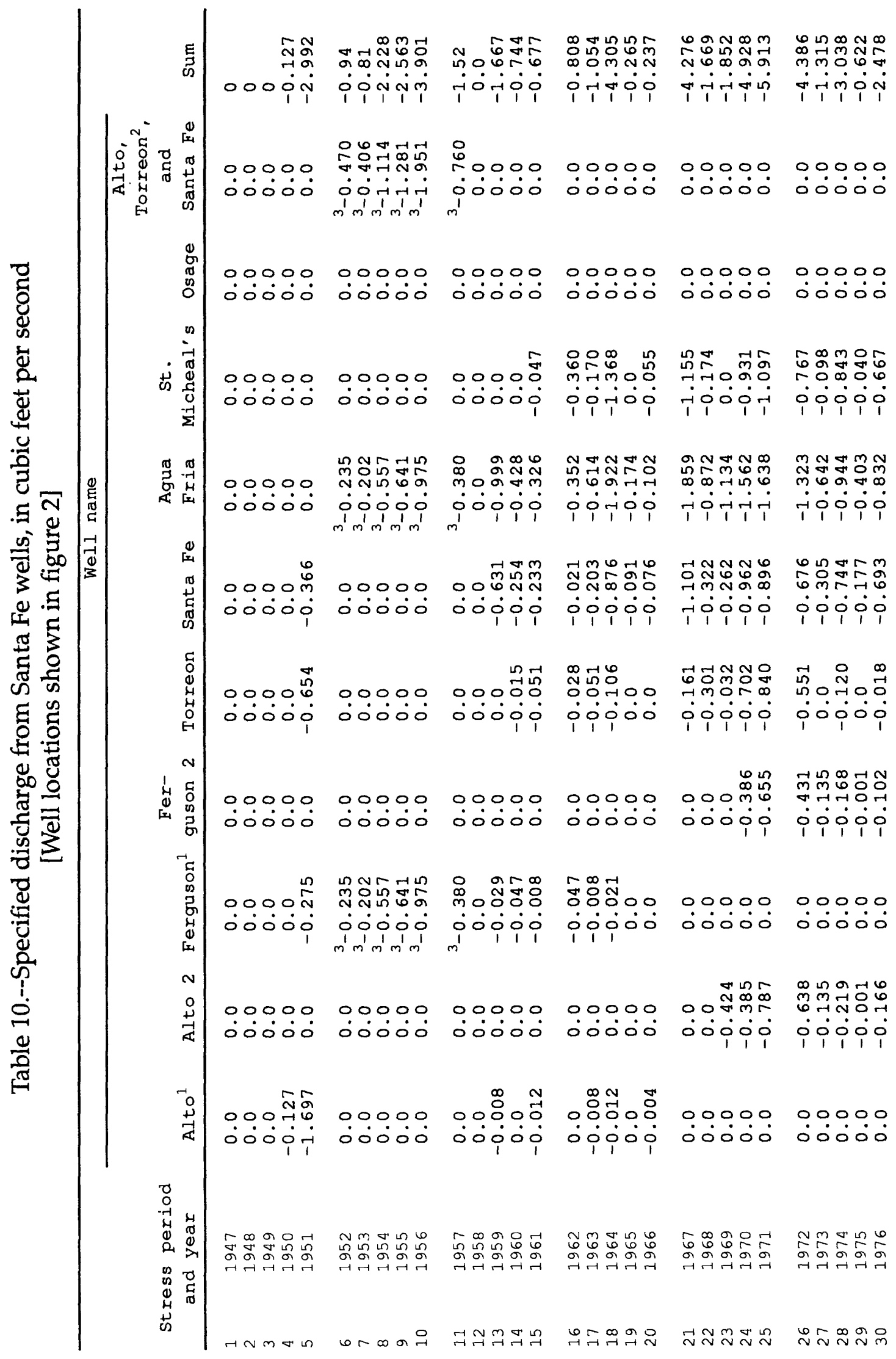




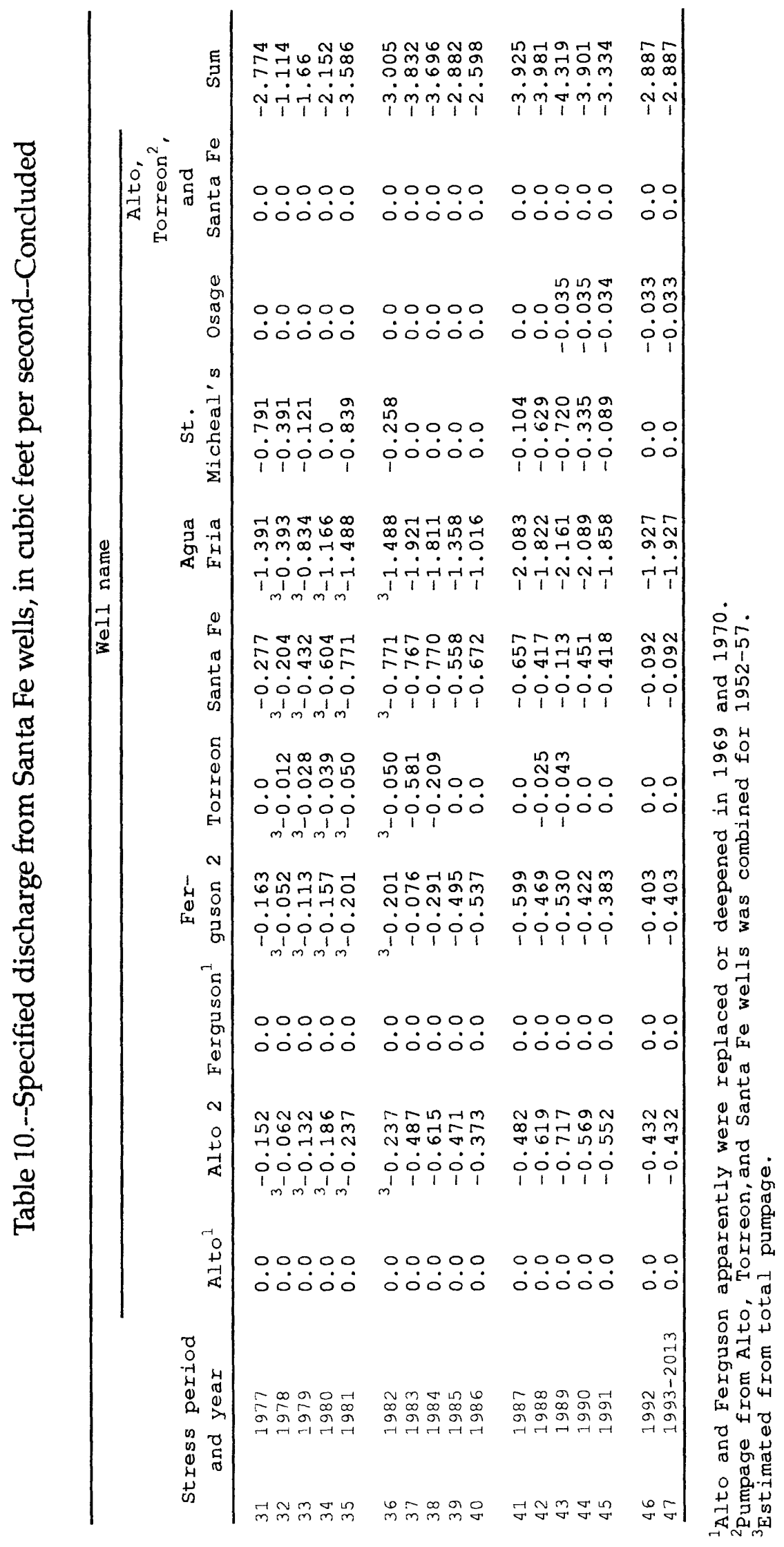


Table 11.-Percentage of public-supply well pumpage assigned to each model layer [Well locations shown in figure 2]

\begin{tabular}{|c|c|c|c|c|c|c|c|}
\hline \multirow[b]{2}{*}{ Row } & \multirow[b]{2}{*}{ Column } & \multirow[b]{2}{*}{ Well name } & \multicolumn{5}{|c|}{ Percent in model layer ${ }^{2}$} \\
\hline & & & 1 & 2 & 3 & 4 & 5 \\
\hline $\begin{array}{l}10 \\
10 \\
10 \\
10 \\
11\end{array}$ & $\begin{array}{r}11 \\
11 \\
11 \\
11 \\
9\end{array}$ & $\begin{array}{l}L A-1 B \\
L A-1 \\
L A-2 \\
L A-3 \\
L A-4\end{array}$ & $\begin{array}{c}0 . \\
17.4 \\
12.5 \\
12.5 \\
0\end{array}$ & $\begin{array}{c}10.9 \\
34.2 \\
36.2 \\
36.2 \\
0\end{array}$ & $\begin{array}{l}23.8 \\
40.4 \\
42.8 \\
42.8 \\
11.2\end{array}$ & $\begin{array}{c}34.7 \\
8.07 \\
8.55 \\
8.55 \\
39.3\end{array}$ & $\begin{array}{c}30.6 \\
0 \\
0 \\
0 \\
49.5\end{array}$ \\
\hline $\begin{array}{r}11 \\
10 \\
9 \\
9 \\
8\end{array}$ & $\begin{array}{r}10 \\
10 \\
9 \\
9 \\
9\end{array}$ & $\begin{array}{l}L A-5 \\
L A-6 \\
G-1 \\
G-1 A \\
G-2\end{array}$ & $\begin{array}{c}0 \\
0 \\
0 \\
14.7 \\
10.6\end{array}$ & $\begin{array}{l}8.15 \\
4.42 \\
14.4 \\
22.2 \\
16.4\end{array}$ & $\begin{array}{l}25 \\
23.9 \\
21.8 \\
26.2 \\
19.4\end{array}$ & $\begin{array}{l}36.5 \\
35 \\
31.9 \\
36.9 \\
28.3\end{array}$ & $\begin{array}{c}30.3 \\
36.7 \\
31.9 \\
0 \\
25.4\end{array}$ \\
\hline $\begin{array}{l}8 \\
8 \\
8 \\
8 \\
8\end{array}$ & $\begin{array}{l}8 \\
7 \\
7 \\
6 \\
9\end{array}$ & $\begin{array}{l}\text { G-3 } \\
\text { G-4 } \\
G-5 \\
G-6 \\
\text { GR-2 }\end{array}$ & $\begin{array}{c}2.9 \\
8.07 \\
10.9 \\
0 \\
10.9\end{array}$ & $\begin{array}{l}20.5 \\
18.3 \\
20.1 \\
31.7 \\
20.1\end{array}$ & $\begin{array}{l}24.2 \\
21.7 \\
23.8 \\
46.4 \\
23.8\end{array}$ & $\begin{array}{l}35.3 \\
31.7 \\
34.7 \\
21.9 \\
34.7\end{array}$ & $\begin{array}{c}17.1 \\
20.2 \\
10.5 \\
0 \\
10.5\end{array}$ \\
\hline $\begin{array}{r}8 \\
8 \\
8 \\
11 \\
11\end{array}$ & $\begin{array}{l}8 \\
7 \\
7 \\
9 \\
5\end{array}$ & $\begin{array}{l}\text { GR }-3 \\
G R-4 \\
G R-1 \\
O-1 \\
0-4\end{array}$ & $\begin{array}{c}10.9 \\
10.9 \\
10.9 \\
0 \\
0\end{array}$ & $\begin{array}{c}20.1 \\
20.1 \\
20.1 \\
9.11 \\
10.3\end{array}$ & $\begin{array}{l}23.8 \\
23.8 \\
23.8 \\
22.3 \\
22.3\end{array}$ & $\begin{array}{l}34.7 \\
34.7 \\
34.7 \\
32.5 \\
32.6\end{array}$ & $\begin{array}{l}10.5 \\
10.5 \\
10.5 \\
36.1 \\
34.9\end{array}$ \\
\hline $\begin{array}{l}12 \\
13 \\
11 \\
12 \\
12\end{array}$ & $\begin{array}{l}7 \\
5 \\
6 \\
5 \\
4\end{array}$ & $\begin{array}{l}P M-1 \\
P M-2 \\
P M-3 \\
P M-4 \\
P M-5\end{array}$ & $\begin{array}{l}0 \\
1.47 \\
0 \\
0 \\
0\end{array}$ & $\begin{array}{l}16.3 \\
21.3 \\
16.3 \\
17.3 \\
14.9\end{array}$ & $\begin{array}{l}21 \\
25.2 \\
20.4 \\
20.4 \\
19.9\end{array}$ & $\begin{array}{l}30.7 \\
36.8 \\
29.9 \\
29.8 \\
29.1\end{array}$ & $\begin{array}{l}32.1 \\
15.3 \\
33.4 \\
32.6 \\
36.1\end{array}$ \\
\hline $\begin{array}{l}13 \\
14 \\
14 \\
14 \\
14\end{array}$ & $\begin{array}{l}11 \\
11 \\
11 \\
11 \\
12\end{array}$ & $\begin{array}{l}\text { Buckman-1 } \\
\text { Buckman-2 } \\
\text { Buckman-3 } \\
\text { Buckman-4 } \\
\text { Buckman-5 }\end{array}$ & $\begin{array}{l}0 \\
0 \\
0 \\
0 \\
0\end{array}$ & $\begin{array}{l}25.7 \\
17.7 \\
23.2 \\
1.98 \\
24.1\end{array}$ & $\begin{array}{l}39.7 \\
24.5 \\
28.2 \\
42.8 \\
34.9\end{array}$ & $\begin{array}{l}34.6 \\
35.9 \\
41.2 \\
55.2 \\
41\end{array}$ & $\begin{array}{c}0 \\
21.9 \\
7.4 \\
0 \\
0\end{array}$ \\
\hline $\begin{array}{l}14 \\
14 \\
13 \\
25\end{array}$ & $\begin{array}{l}12 \\
12 \\
11 \\
22\end{array}$ & $\begin{array}{l}\text { Buckman-6 } \\
\text { Buckman-7 } \\
\text { Buckman-8 } \\
\text { St. Micheal's }\end{array}$ & $\begin{array}{c}0 \\
0 \\
0 \\
23.5\end{array}$ & $\begin{array}{c}20.8 \\
4.03 \\
18.3 \\
45.8\end{array}$ & $\begin{array}{l}37.9 \\
65.5 \\
62.5 \\
30.7\end{array}$ & $\begin{array}{c}41.3 \\
30.4 \\
19.2 \\
0\end{array}$ & $\begin{array}{l}0 \\
0 \\
0 \\
0\end{array}$ \\
\hline $\begin{array}{l}24 \\
24 \\
24 \\
24 \\
23\end{array}$ & $\begin{array}{l}22 \\
22 \\
21 \\
22 \\
22\end{array}$ & $\begin{array}{l}\text { Alto } \\
\text { Alto } 2 \\
\text { Osage } \\
\text { Torreon } \\
\text { Ferguson }\end{array}$ & $\begin{array}{r}72.2 \\
8.5 \\
27.2 . \\
35.5 \\
45.8\end{array}$ & $\begin{array}{l}27.8 \\
55.7 \\
37.5 \\
48.8 \\
54.2\end{array}$ & $\begin{array}{c}0 \\
35.8 \\
35.3 \\
15.6 \\
0\end{array}$ & $\begin{array}{l}0 \\
0 \\
0 \\
0 \\
0\end{array}$ & $\begin{array}{l}0 \\
0 \\
0 \\
0 \\
0\end{array}$ \\
\hline $\begin{array}{l}23 \\
24 \\
24 \\
24\end{array}$ & $\begin{array}{l}22 \\
22 \\
21 \\
22\end{array}$ & $\begin{array}{l}\text { Ferguson } 2 \\
\text { Santa Fe } \\
\text { Agua Fria } \\
\mathrm{A}, \mathrm{T}, \& \mathrm{SF}^{1}\end{array}$ & $\begin{array}{l}14 \\
14 \\
28.9 \\
26.3\end{array}$ & $\begin{array}{l}48.2 \\
19.3 \\
39.7 \\
27.7\end{array}$ & $\begin{array}{l}37.8 \\
22.8 \\
31.5 \\
18.3\end{array}$ & $\begin{array}{c}0 \\
33.3 \\
0 \\
21\end{array}$ & $\begin{array}{l}0 \\
10.6 \\
0 \\
6.68\end{array}$ \\
\hline
\end{tabular}

${ }^{1}$ Alto, Torreon, and santa Fe wells, when these wells were combined.

${ }^{2}$ Total percent does not equal 100 due to rounding. 
Table 12.--Specified discharge from domestic and industrial wells, in cubic feet per second

\begin{tabular}{|c|c|c|c|c|c|}
\hline $\begin{array}{l}\text { Stress } \\
\text { period }\end{array}$ & Year & $\begin{array}{l}\text { Specified } \\
\text { discharge }\end{array}$ & $\begin{array}{l}\text { Stress } \\
\text { period }\end{array}$ & Year & $\begin{array}{l}\text { Specified } \\
\text { discharge }\end{array}$ \\
\hline 1 & 1947 & -0.174 & 26 & 1972 & -1.053 \\
\hline 2 & 1948 & -0.252 & 27 & 1973 & -1.053 \\
\hline 3 & 1949 & -0.258 & 28 & 1974 & -1.129 \\
\hline 4 & 1950 & -0.264 & 29 & 1975 & -1.129 \\
\hline 5 & 1951 & -0.292 & 30 & 1976 & -1.144 \\
\hline 6 & 1952 & -0.310 & 31 & 1977 & -1.144 \\
\hline 7 & 1953 & -0.317 & 32 & 1978 & -1.144 \\
\hline 8 & 1954 & -0.317 & 33 & 1979 & -1.144 \\
\hline 9 & 1955 & -0.590 & 34 & 1980 & -1.144 \\
\hline 10 & 1956 & -0.590 & 35 & 1981 & -1.144 \\
\hline 11 & 1957 & -0.625 & 36 & 1982 & -1.144 \\
\hline 12 & 1958 & -0.625 & 37 & 1983 & -1.179 \\
\hline 13 & 1959 & -0.625 & 38 & 1984 & -1.215 \\
\hline 14 & 1960 & -0.625 & 39 & 1985 & -1.250 \\
\hline 15 & 1961 & -0.625 & 40 & 1986 & -1.286 \\
\hline 16 & 1962 & -0.625 & 41 & 1987 & -1.322 \\
\hline 17 & 1963 & -0.635 & 42 & 1988 & -1.357 \\
\hline 18 & 1964 & -0.635 & 43 & 1989 & -1.392 \\
\hline 19 & 1965 & -1.032 & 44 & 1990 & -1.428 \\
\hline 20 & 1966 & -1.032 & 45 & 1991 & -1.463 \\
\hline 21 & 1967 & -1.041 & 46 & 1992 & -1.499 \\
\hline 22 & 1968 & -1.041 & 47 & $1993-2013$ & -1.499 \\
\hline 23 & 1969 & -1.041 & & & \\
\hline 24 & 1970 & -1.041 & & & \\
\hline 25 & 1971 & -1.041 & & & \\
\hline
\end{tabular}


Table 13.--Difference between measured and model-derived hydraulic heads, in feet

\begin{tabular}{|c|c|c|c|c|c|}
\hline \multicolumn{2}{|c|}{ Model } & \multirow{2}{*}{$\begin{array}{c}\text { Local well name } \\
\text { or number }\end{array}$} & \multicolumn{2}{|c|}{ Hydraulic head } & \multirow{2}{*}{$\begin{array}{l}\text { Difference } \\
\text { (model } \\
\text { derived } \\
\text { minus } \\
\text { measured) }\end{array}$} \\
\hline Row & Column & & Measured & derived & \\
\hline $\begin{array}{l}5 \\
6 \\
6 \\
6 \\
7\end{array}$ & $\begin{array}{l}19 \\
15 \\
18 \\
19 \\
15\end{array}$ & $\begin{array}{l}\quad \text { Steady state, } \\
20.09 .18 .4421 \\
20.08 .34 .144 \\
20.09 .30 .31233 \\
20.09 .19 .4244 \\
20.08 .34 .14423\end{array}$ & $\begin{array}{l}\text { model } 1 \\
5,752 . \\
5,559 . \\
5,830 . \\
5,743 . \\
5,549 .\end{array}$ & $\begin{array}{l}r \quad 1 \\
5,845.3 \\
5,642.3 \\
5,807.7 \\
5,861.2 \\
5,660.1\end{array}$ & $\begin{array}{r}93.3 \\
83.3 \\
-22.3 \\
118.2 \\
111.1\end{array}$ \\
\hline $\begin{array}{l}7 \\
7 \\
8 \\
8 \\
8\end{array}$ & $\begin{array}{l}19 \\
22 \\
19 \\
21 \\
23\end{array}$ & $\begin{array}{l}20.09 \cdot 32.310 \\
20.09 .34 .411 \\
19.09 .05 .131 \\
19.09 .03 .311 \\
20.09 .36 .344\end{array}$ & $\begin{array}{l}5,834 \\
6,038 \\
5,832 \\
6,005 \\
6,299\end{array}$ & $\begin{array}{l}5,873.5 \\
6,053.7 \\
5,877.8 \\
6,001.5 \\
6,148.2\end{array}$ & $\begin{array}{r}39.5 \\
15.7 \\
45.8 \\
-3.5 \\
-150.8\end{array}$ \\
\hline $\begin{array}{l}9 \\
9 \\
9 \\
9 \\
9\end{array}$ & $\begin{array}{l}15 \\
16 \\
19 \\
20 \\
20\end{array}$ & $\begin{array}{l}19.08 .10 .324 \\
19.08 .11 .144 \\
19.09 .08 .133 \\
19.09 .08 .233 \\
19.09 .08 .224\end{array}$ & $\begin{array}{l}5,625 \\
5,680 \\
5,835 \\
5,887 \\
5,890\end{array}$ & $\begin{array}{l}5,615.3 \\
5,675.1 \\
5,854.9 \\
5,925.6 \\
5,925.6\end{array}$ & $\begin{array}{l}-9.7 \\
-4.9 \\
19.9 \\
38.6 \\
35.6\end{array}$ \\
\hline $\begin{array}{r}9 \\
9 \\
9 \\
9 \\
10\end{array}$ & $\begin{array}{r}20 \\
21 \\
21 \\
22 \\
3\end{array}$ & $\begin{array}{l}19.09 .09 .1444 \\
19.09 .03 .341 \\
19.09 \cdot 10.122 \\
19.09 .10 .224 \\
\text { TW-4 }\end{array}$ & $\begin{array}{l}5,928 . \\
6,024 . \\
6,030 . \\
6,043 . \\
6,073.59\end{array}$ & $\begin{array}{l}5,925.6 \\
5,989.0 \\
5,989.0 \\
6,092.9 \\
6,059.9\end{array}$ & $\begin{array}{r}-2.4 \\
-35.0 \\
-41.0 \\
49.9 \\
-13.7\end{array}$ \\
\hline $\begin{array}{l}10 \\
10 \\
10 \\
10 \\
10\end{array}$ & $\begin{array}{r}5 \\
14 \\
15 \\
16 \\
18\end{array}$ & $\begin{array}{l}\text { TW-2 } \\
19.08 .16 .131 \\
19.08 .15 .411 \\
19.08 .14 .144 \\
19.08 .12 .433\end{array}$ & $\begin{array}{l}5,889.16 \\
5,683 . \\
5,666 . \\
5,697 . \\
5,740 .\end{array}$ & $\begin{array}{l}5,905.2 \\
5,749.9 \\
5,762.8 \\
5,782.9 \\
5,858.1\end{array}$ & $\begin{array}{r}16.0 \\
66.9 \\
96.8 \\
85.9 \\
118.1\end{array}$ \\
\hline $\begin{array}{l}10 \\
10 \\
10 \\
10 \\
10\end{array}$ & $\begin{array}{l}19 \\
19 \\
19 \\
20 \\
22\end{array}$ & $\begin{array}{l}19.09 .07 .424 \\
19.09 .17 .123 \\
19.09 .17 .142 \\
19.09 .17 .210 \\
19.09 .15 .412\end{array}$ & $\begin{array}{l}5,826 \\
5,849 . \\
5,871 . \\
5,884 \\
5,989 .\end{array}$ & $\begin{array}{l}5,883.4 \\
5,883.4 \\
5,883.4 \\
5,980.1 \\
6,109.6\end{array}$ & $\begin{array}{r}57.4 \\
34.4 \\
12.4 \\
96.1 \\
120.6\end{array}$ \\
\hline $\begin{array}{l}10 \\
11 \\
11 \\
11 \\
11\end{array}$ & $\begin{array}{r}25 \\
4 \\
5 \\
8 \\
18\end{array}$ & $\begin{array}{l}19.10 .18 .231 \\
\mathrm{TW}-8 \\
\mathrm{TW}-3 \\
\mathrm{TW}-1 \\
19.08 .13 .431\end{array}$ & $\begin{array}{l}6,623 . \\
5,908.90 \\
5,952.01 \\
5,784.29 \\
5,833 .\end{array}$ & $\begin{array}{l}6,574.2 \\
5,940.1 \\
5,903.3 \\
5,838.6 \\
5,899.6\end{array}$ & $\begin{array}{r}-48.8 \\
31.2 \\
-48.7 \\
54.3 \\
66.6\end{array}$ \\
\hline $\begin{array}{l}11 \\
11 \\
11 \\
11 \\
12\end{array}$ & $\begin{array}{l}19 \\
20 \\
20 \\
23 \\
20\end{array}$ & $\begin{array}{l}19.09 .20 .124 \\
19.09 .20 .223 \\
19.09 .20 .244 \\
19.09 .14 .441 \\
19.09 .29 .214\end{array}$ & $\begin{array}{l}5,944 . \\
5,967 . \\
5,989 . \\
6,147 . \\
5,991 .\end{array}$ & $\begin{array}{l}5,918.5 \\
6,020.3 \\
6,020.3 \\
6,229.8 \\
6,049.0\end{array}$ & $\begin{array}{r}-25.5 \\
53.3 \\
31.3 \\
82.8 \\
58.0\end{array}$ \\
\hline $\begin{array}{l}12 \\
12 \\
13 \\
13 \\
14\end{array}$ & $\begin{array}{r}20 \\
24 \\
19 \\
25 \\
4\end{array}$ & $\begin{array}{l}19.09 .28 .143 \\
19.09 .25 .432 \\
19.09 .29 .331 \\
19.10 .29 .341 \\
\text { DT-10 }\end{array}$ & $\begin{array}{l}6,052 . \\
6,295 . \\
6,096 \\
6,795 . \\
5,928.35\end{array}$ & $\begin{array}{l}6,049.0 \\
6,471 \cdot 3 \\
6,042.5 \\
6,751.3 \\
5,935.7\end{array}$ & $\begin{array}{r}-3.0 \\
176.3 \\
-53.5 \\
-43.7 \\
7.4\end{array}$ \\
\hline
\end{tabular}


Table 13.--Difference between measured and model-derived hydraulic heads, in feet--Continued

\begin{tabular}{|c|c|c|c|c|c|}
\hline \multicolumn{2}{|c|}{ Model } & \multirow{2}{*}{$\begin{array}{c}\text { Local well name } \\
\text { or number }\end{array}$} & \multicolumn{2}{|c|}{ Hydraulic head } & \multirow{2}{*}{$\begin{array}{l}\text { Difference } \\
\text { (model } \\
\text { derived } \\
\text { minus } \\
\text { measured) }\end{array}$} \\
\hline Row & Column & & Measured & derived & \\
\hline $\begin{array}{l}14 \\
14 \\
14 \\
14 \\
14\end{array}$ & $\begin{array}{l}14 \\
21 \\
21 \\
22 \\
24\end{array}$ & $\begin{array}{l}19.08 .32 .443 \\
18.09 .03 .112 \\
18.09 .03 .142 \\
18.09 .02 .133 \\
18.10 .06 .112\end{array}$ & $\begin{array}{l}5,766 . \\
6,235 . \\
6,262 . \\
6,391 . \\
6,701 .\end{array}$ & $\begin{array}{l}5,849.7 \\
6,216.8 \\
6,216.8 \\
6,328.9 \\
6,649.8\end{array}$ & $\begin{array}{r}83 \cdot 7 \\
-18 \cdot 2 \\
-45.2 \\
-62.1 \\
-51.2\end{array}$ \\
\hline $\begin{array}{l}14 \\
14 \\
14 \\
15 \\
15\end{array}$ & $\begin{array}{r}24 \\
25 \\
25 \\
4 \\
15\end{array}$ & $\begin{array}{l}18.10 .06 .111 \\
18.10 .06 .243 \\
18.10 .06 .244 \\
\text { DT-9 } \\
18.08 .10 .143\end{array}$ & $\begin{array}{l}6,702 . \\
6,812 . \\
6,840 \\
5,933.71 \\
5,850\end{array}$ & $\begin{array}{l}6,649.8 \\
6,876.8 \\
6,876.8 \\
5,933.5 \\
5,886.4\end{array}$ & $\begin{array}{r}-52.2 \\
64.8 \\
36.8 \\
-0.2 \\
36.4\end{array}$ \\
\hline $\begin{array}{l}15 \\
16 \\
16 \\
16 \\
16\end{array}$ & $\begin{array}{l}22 \\
14 \\
24 \\
24 \\
24\end{array}$ & $\begin{array}{l}18.09 .10 .224 \\
18.08 .17 .223 \\
18.10 .07 .342 \\
18.10 .07 .342 \\
18.10 .18 .131\end{array}$ & $\begin{array}{l}6,340 \\
5,825 \\
6,688 \\
6,688 \\
6,724\end{array}$ & $\begin{array}{l}6,368 \cdot 8 \\
5,877 \cdot 2 \\
6,629 \cdot 5 \\
6,629 \cdot 5 \\
6,629 \cdot 5\end{array}$ & $\begin{array}{r}28.8 \\
52.2 \\
-58.5 \\
-58.5 \\
-94.5\end{array}$ \\
\hline $\begin{array}{l}16 \\
17 \\
18 \\
18 \\
18\end{array}$ & $\begin{array}{l}24 \\
23 \\
17 \\
23 \\
23\end{array}$ & $\begin{array}{l}18.10 .18 .132 \\
18.09 .24 .111 \\
18.08 .24 .300 \\
18.09 .25 .113 \\
18.09 .25 .13111\end{array}$ & $\begin{array}{l}6,725 \\
6,564 \\
6,105 \\
6,652 \\
6,653\end{array}$ & $\begin{array}{l}6,629 \cdot 5 \\
6,611 \cdot 7 \\
6,074 \cdot 5 \\
6,690.1 \\
6,690.1\end{array}$ & $\begin{array}{r}-95.5 \\
47.7 \\
-30.5 \\
38.1 \\
37.1\end{array}$ \\
\hline $\begin{array}{l}18 \\
19 \\
19 \\
19 \\
19\end{array}$ & $\begin{array}{l}25 \\
12 \\
14 \\
14 \\
20\end{array}$ & $\begin{array}{l}18.10 .30 .421 \\
18.07 .36 .422 \\
18.08 .33 .143 \\
18.08 .33 .143 \\
18.09 .33 .233\end{array}$ & $\begin{array}{l}6,808 \\
5,720 \\
5,800 \\
5,836 \\
6,339\end{array}$ & $\begin{array}{l}6,850.4 \\
5,852 \cdot 0 \\
5,907.2 \\
5,907.2 \\
6,352.8\end{array}$ & $\begin{array}{r}42.4 \\
132.0 \\
107.2 \\
71.2 \\
13.8\end{array}$ \\
\hline $\begin{array}{l}19 \\
19 \\
19 \\
20 \\
20\end{array}$ & $\begin{array}{l}22 \\
23 \\
24 \\
13 \\
17\end{array}$ & $\begin{array}{l}18.09 .27 .431 \\
18.09 .25 .433 \\
18.10 .31 .413 \\
17.08 .05 .323 \\
17.08 .01 .212\end{array}$ & $\begin{array}{l}6,639 \\
6,760 \\
6,904 \\
5,843 \\
6,145\end{array}$ & $\begin{array}{l}6,551 \cdot 6 \\
6,679 \cdot 5 \\
6,849 \cdot 2 \\
5,891 \cdot 2 \\
6,144 \cdot 6\end{array}$ & $\begin{array}{r}-87.4 \\
-80.5 \\
-54.8 \\
48.2 \\
-0.4\end{array}$ \\
\hline $\begin{array}{l}20 \\
20 \\
20 \\
20 \\
20\end{array}$ & $\begin{array}{l}17 \\
19 \\
21 \\
23 \\
25\end{array}$ & $\begin{array}{l}17.08 .01 .212 \\
17.09 .06 .223 \\
17.09 .03 .124 \\
17.09 .01 .121 \\
17.10 .06 .242\end{array}$ & $\begin{array}{l}6,149 \\
6,220 \\
6,699 \\
6,875 \\
7,012\end{array}$ & $\begin{array}{l}6,144.6 \\
6,298.8 \\
6,479.3 \\
6,696.0 \\
7,055.7\end{array}$ & $\begin{array}{r}-4.4 \\
78.8 \\
-219.7 \\
-179.0 \\
43.7\end{array}$ \\
\hline $\begin{array}{l}20 \\
21 \\
21 \\
22 \\
23\end{array}$ & $\begin{array}{l}25 \\
23 \\
24 \\
22 \\
22\end{array}$ & $\begin{array}{l}17.10 .05 .112 \\
17.09 .01 .334 \\
17.09 .12 .222 \\
17.09 .15 .2432 \\
17.09 .23 .133\end{array}$ & $\begin{array}{l}7,059 \\
6,730 \\
6,850 \\
6,768 \\
6,807\end{array}$ & $\begin{array}{l}7,055.7 \\
6,727.0 \\
6,868.8 \\
6,666.5 \\
6,756.2\end{array}$ & $\begin{array}{r}-3.3 \\
-3.0 \\
18.8 \\
-101.5 \\
-50.8\end{array}$ \\
\hline $\begin{array}{l}23 \\
23 \\
23 \\
23 \\
23\end{array}$ & $\begin{array}{l}22 \\
23 \\
23 \\
23 \\
24\end{array}$ & $\begin{array}{l}17.09 .23 .322 \\
17.09 .24 .114 \\
17.09 .24 .124 \mathrm{~A} \\
17.09 .24 .324 \\
17.10 .18 .333\end{array}$ & $\begin{array}{l}6,823 \\
6,916 \\
6,949 \\
6,970 \\
6,939 .\end{array}$ & $\begin{array}{l}6,756 \cdot 2 \\
6,881 \cdot 3 \\
6,881 \cdot 3 \\
6,881 \cdot 3 \\
7,047 \cdot 0\end{array}$ & $\begin{array}{l}-66.8 \\
-34.7 \\
-67.7 \\
-88.7 \\
108.0\end{array}$ \\
\hline $\begin{array}{l}24 \\
24 \\
24 \\
24 \\
24\end{array}$ & $\begin{array}{l}14 \\
20 \\
21 \\
21 \\
21\end{array}$ & $\begin{array}{l}17.08 .21 .414 \\
17.09 .28 .321 \\
17.09 .22 .343 \\
17.09 .27 .143 \\
17.09 .27 .144\end{array}$ & $\begin{array}{l}6,139 . \\
6,570 . \\
6,726 . \\
6,749 . \\
6,752 .\end{array}$ & $\begin{array}{l}6,135.5 \\
6,525.0 \\
6,698.1 \\
6,698.1 \\
6,698.1\end{array}$ & $\begin{array}{r}-3.5 \\
-45.0 \\
-27.9 \\
-50.9 \\
-53.9\end{array}$ \\
\hline
\end{tabular}


Table 13.--Difference between measured and model-derived hydraulic heads, in feet--Continued

\begin{tabular}{|c|c|c|c|c|c|}
\hline \multicolumn{2}{|c|}{ Model } & \multirow{2}{*}{$\begin{array}{c}\text { Local well name } \\
\text { or number }\end{array}$} & \multicolumn{2}{|c|}{ Hydraulic head } & \multirow{2}{*}{$\begin{array}{c}\text { Difference } \\
\text { (model } \\
\text { derived } \\
\text { minus } \\
\text { measured) }\end{array}$} \\
\hline Row & Column & & Measured & derived & \\
\hline $\begin{array}{l}24 \\
24 \\
24 \\
24 \\
24\end{array}$ & $\begin{array}{l}21 \\
22 \\
22 \\
22 \\
23\end{array}$ & $\begin{array}{l}17.09 .27 .232 \\
17.09 .27 .241 \\
17.09 .23 .333 \\
17.09 .23 .332 \\
17.09 .26 .222\end{array}$ & $\begin{array}{l}6,764 . \\
6,744 \\
6,786 \\
6,799 \\
6,917 .\end{array}$ & $\begin{array}{l}6,698.1 \\
6,786.9 \\
6,786.9 \\
6,786.9 \\
6,926.2\end{array}$ & $\begin{array}{r}-65.9 \\
42.9 \\
0.9 \\
-12.1 \\
9.2\end{array}$ \\
\hline $\begin{array}{l}24 \\
24 \\
24 \\
24 \\
24\end{array}$ & $\begin{array}{l}23 \\
23 \\
24 \\
24 \\
24\end{array}$ & $\begin{array}{l}17.09 .24 .343 \\
17.09 .25 .324 \\
17.09 .24 .432 \\
17.10 .19 .331 \\
17.09 .25 .421\end{array}$ & $\begin{array}{l}6,971 \\
6,991 \\
6,998 \\
7,025 \\
7,058\end{array}$ & $\begin{array}{l}6,926.2 \\
6,926.2 \\
7,164.7 \\
7,164.7 \\
7,164.7\end{array}$ & $\begin{array}{l}-44.8 \\
-64.8 \\
166.7 \\
139.7 \\
106.7\end{array}$ \\
\hline $\begin{array}{l}24 \\
24 \\
25 \\
25 \\
25\end{array}$ & $\begin{array}{l}24 \\
24 \\
18 \\
19 \\
21\end{array}$ & $\begin{array}{l}17.10 .30 .131 \\
17.10 .30 .123 \\
17.09 .30 .433 \\
17.09 .32 .111 \\
17.09 .33 .421\end{array}$ & $\begin{array}{l}7,078 \\
7,085 \\
6,163 \\
6,285 \\
6,560\end{array}$ & $\begin{array}{l}7,164.7 \\
7,164.7 \\
6,250.1 \\
6,547.7 \\
6,632.6\end{array}$ & $\begin{array}{r}86.7 \\
79.7 \\
87.1 \\
262.7 \\
72.6\end{array}$ \\
\hline $\begin{array}{l}25 \\
25 \\
25 \\
25 \\
25\end{array}$ & $\begin{array}{l}22 \\
23 \\
24 \\
24 \\
24\end{array}$ & $\begin{array}{l}17.09 .27 .441 \\
17.09 .25 .343 \\
17.09 .36 .243 \\
17.09 .36 .422 \\
17.10 .31 .134\end{array}$ & $\begin{array}{l}6,746 \\
6,990 \\
7,023 \\
7,028 \\
7,089\end{array}$ & $\begin{array}{l}6,725.5 \\
6,869.9 \\
7,177.6 \\
7,177.6 \\
7,177.6\end{array}$ & $\begin{array}{r}-20.5 \\
-120.1 \\
154.6 \\
149.6 \\
88.6\end{array}$ \\
\hline $\begin{array}{l}26 \\
26 \\
26 \\
26 \\
26\end{array}$ & $\begin{array}{l}14 \\
15 \\
19 \\
20 \\
21\end{array}$ & $\begin{array}{l}16.08 .04 .132 \\
17.08 .34 .342 \\
17.09 .31 .44221 \\
17.09 .33 .211 \mathrm{~A} \\
16.09 .03 .312\end{array}$ & $\begin{array}{l}6,133 \\
6,177 \\
6,308 \\
6,552 \\
6,538\end{array}$ & $\begin{array}{l}6,160.9 \\
6,177.2 \\
6,352.5 \\
6,492.1 \\
6,589.9\end{array}$ & $\begin{array}{r}27.9 \\
0.2 \\
44.5 \\
-59.9 \\
51.9\end{array}$ \\
\hline $\begin{array}{l}26 \\
26 \\
26 \\
26 \\
26\end{array}$ & $\begin{array}{l}21 \\
22 \\
22 \\
22 \\
23\end{array}$ & $\begin{array}{l}16.09 .03 .134 \\
16.09 .02 .31212 \\
16.09 .02 .121 \\
17.09 .34 .422 \\
16.09 .01 .11344\end{array}$ & $\begin{array}{l}6,562 \\
6,692 \\
6,710 \\
6,727 \\
6,796\end{array}$ & $\begin{array}{l}6,589.9 \\
6,684.2 \\
6,684.2 \\
6,684.2 \\
6,791.0\end{array}$ & $\begin{array}{r}27.9 \\
-7.8 \\
-25.8 \\
-42.8 \\
-5.0\end{array}$ \\
\hline $\begin{array}{l}26 \\
27 \\
27 \\
27 \\
27\end{array}$ & $\begin{array}{l}23 \\
14 \\
16 \\
17 \\
17\end{array}$ & $\begin{array}{l}17.09 .36 .323 \\
16.08 .09 .421 \\
16.08 .10 .422 \\
16.08 .01 .34223 \\
16.08 .12 .322\end{array}$ & $\begin{array}{l}6,868 \\
6,122 \\
6,157 \\
6,171 \\
6,175\end{array}$ & $\begin{array}{l}6,791.0 \\
6,161.3 \\
6,199.4 \\
6,224.0 \\
6,224.0\end{array}$ & $\begin{array}{r}-77.0 \\
39.3 \\
42.4 \\
53.0 \\
49.0\end{array}$ \\
\hline $\begin{array}{l}27 \\
27 \\
27 \\
27 \\
27\end{array}$ & $\begin{array}{l}19 \\
19 \\
20 \\
21 \\
21\end{array}$ & $\begin{array}{l}16.09 .05 .334 \\
16.09 .05 .331 \\
16.09 .09 .321 \\
16.09 .09 .221 \\
16.09 .03 .421\end{array}$ & $\begin{array}{l}6,337 \\
6,338 \\
6,513 \\
6,531 \\
6,679\end{array}$ & $\begin{array}{l}6,327.0 \\
6,327.0 \\
6,453.0 \\
6,558.0 \\
6,558.0\end{array}$ & $\begin{array}{r}-10.0 \\
-11.0 \\
-60.0 \\
27.0 \\
-121.0\end{array}$ \\
\hline $\begin{array}{l}27 \\
27 \\
27 \\
27 \\
27\end{array}$ & $\begin{array}{l}22 \\
22 \\
22 \\
23 \\
23\end{array}$ & $\begin{array}{l}16.09 .10 .242 \\
16.09 .10 .42114 \\
16.09 .02 .33241 \\
16.09 .02 .441 \\
16.09 .01 .31121\end{array}$ & $\begin{array}{l}6,657 \\
6,670 \\
6,681 \\
6,758 \\
6,792\end{array}$ & $\begin{array}{l}6,656.6 \\
6,656.6 \\
6,656.6 \\
6,744.1 \\
6,744.1\end{array}$ & $\begin{array}{r}-0.4 \\
-13.4 \\
-24.4 \\
-13.9 \\
-47.9\end{array}$ \\
\hline $\begin{array}{l}28 \\
28 \\
28 \\
28 \\
28\end{array}$ & $\begin{array}{l}13 \\
15 \\
17 \\
18 \\
18\end{array}$ & $\begin{array}{l}16.08 .17 .2122 \\
16.08 .15 .143 \\
16.08 .12 .332 \\
16.08 .13 .243 \\
16.08 .13 .243\end{array}$ & $\begin{array}{l}6,158 \\
6,167 \\
6,156 \\
6,163 \\
6,163 .\end{array}$ & $\begin{array}{l}6,139 \cdot 8 \\
6,169 \cdot 4 \\
6,207.3 \\
6,225.0 \\
6,225.0\end{array}$ & $\begin{array}{r}-18 \cdot 2 \\
2 \cdot 4 \\
51.3 \\
62.0 \\
62.0\end{array}$ \\
\hline
\end{tabular}


Table 13.--Difference between measured and model-derived hydraulic heads, in feet--Continued

\begin{tabular}{|c|c|c|c|c|c|}
\hline \multicolumn{2}{|c|}{ Model } & \multirow{2}{*}{$\begin{array}{c}\text { Local well name } \\
\text { or number }\end{array}$} & \multicolumn{2}{|c|}{ Hydraulic head } & \multirow{2}{*}{$\begin{array}{c}\text { Difference } \\
\text { (model } \\
\text { derived } \\
\text { minus } \\
\text { measured) }\end{array}$} \\
\hline Row & Column & & Measured & derived & \\
\hline $\begin{array}{l}28 \\
28 \\
28 \\
29 \\
29\end{array}$ & $\begin{array}{l}21 \\
22 \\
22 \\
17 \\
17\end{array}$ & $\begin{array}{l}16.09 .16 .243 \\
16.09 .15 .223 \\
16.09 .15 .242 \\
16.08 .13 .323 \\
16.08 .24 .144\end{array}$ & $\begin{array}{l}6,485 . \\
6,632 . \\
6,784 . \\
6,164 . \\
6,165 .\end{array}$ & $\begin{array}{l}6,528.0 \\
6,672.8 \\
6,672.8 \\
6.195 .8 \\
6,195.8\end{array}$ & $\begin{array}{r}43.0 \\
40.8 \\
-111.2 \\
31.8 \\
30.8\end{array}$ \\
\hline $\begin{array}{l}29 \\
29 \\
29 \\
29 \\
29\end{array}$ & $\begin{array}{l}17 \\
18 \\
18 \\
19 \\
22\end{array}$ & $\begin{array}{l}16.08 .14 .444 \\
16.08 .24 .421 \\
16.08 .13 .444 \\
16.09 .19 .221 \\
16.09 .23 .311\end{array}$ & $\begin{array}{l}6,167 \\
6,122 \\
6,218 \\
6,207 \\
6,578\end{array}$ & $\begin{array}{l}6,195.8 \\
6,212.2 \\
6,212.2 \\
6.267 .1 \\
6,585.9\end{array}$ & $\begin{array}{r}28.8 \\
90.2 \\
-5.8 \\
60.1 \\
7.9\end{array}$ \\
\hline $\begin{array}{l}29 \\
30 \\
30 \\
30 \\
30\end{array}$ & $\begin{array}{l}23 \\
16 \\
17 \\
20 \\
20\end{array}$ & $\begin{array}{l}16.09 .24 .112 \\
16.08 .23 .434 \\
16.08 .24 .333 \\
16.09 .29 .241 \\
16.09 .28 .113\end{array}$ & $\begin{array}{l}6,702 . \\
6,139 \\
6,146 \\
6,330 \\
6,363 .\end{array}$ & $\begin{array}{l}6,679.7 \\
6,167.5 \\
6,188.2 \\
6,326.9 \\
6,326.9\end{array}$ & $\begin{array}{r}-22.3 \\
28.5 \\
42.2 \\
-3.1 \\
-36.1\end{array}$ \\
\hline $\begin{array}{l}31 \\
31 \\
32 \\
32 \\
33\end{array}$ & $\begin{array}{r}16 \\
18 \\
9 \\
17 \\
13\end{array}$ & $\begin{array}{l}16.08 .35 .111 \\
16.08 .25 .424 \\
16.07 .33 .444 \\
15.08 .01 .321 \\
15.08 .07 .242\end{array}$ & $\begin{array}{l}6,130 \\
6,179 \\
5,580 \\
6,160 \\
5,999 .\end{array}$ & $\begin{array}{l}6,157.3 \\
6,200.6 \\
5,614.4 \\
6,177.0 \\
6,002.7\end{array}$ & $\begin{array}{r}27.3 \\
21.6 \\
34.4 \\
17.0 \\
3.7\end{array}$ \\
\hline \multirow[t]{2}{*}{$\begin{array}{l}33 \\
33\end{array}$} & $\begin{array}{l}16 \\
21\end{array}$ & $\begin{array}{l}15.08 .10 .244 \\
15.09 .09 .222\end{array}$ & $\begin{array}{l}6,144 \\
6,370\end{array}$ & $\begin{array}{l}6,138.2 \\
6,379.2\end{array}$ & $\begin{array}{r}-5.8 \\
9.2\end{array}$ \\
\hline & & Steady state, & model la & er 2 & \\
\hline \multirow[t]{2}{*}{$\begin{array}{l}10 \\
14\end{array}$} & $\begin{array}{r}11 \\
3\end{array}$ & $\begin{array}{l}\mathrm{LA}-1 \\
\mathrm{DT}-5 \mathrm{~A}\end{array}$ & $\begin{array}{l}5,605 \\
5,970.84\end{array}$ & $\begin{array}{l}5,686.2 \\
5,973.1\end{array}$ & $\begin{array}{r}81.2 \\
2.3\end{array}$ \\
\hline & & steady state, & model 1 & er 3 & \\
\hline $\begin{array}{l}8 \\
8 \\
8 \\
8 \\
9\end{array}$ & $\begin{array}{l}7 \\
7 \\
7 \\
9 \\
9\end{array}$ & $\begin{array}{l}G-6 \\
G-4 \\
G-5 \\
G-2 \\
G-1 A\end{array}$ & $\begin{array}{l}5,841 \\
5,871 \\
5,892 \\
5,795 \\
5,749\end{array}$ & $\begin{array}{l}5,874.2 \\
5,874.2 \\
5,874.2 \\
5,804.7 \\
5,804.6\end{array}$ & $\begin{array}{r}33.2 \\
3.2 \\
-17.8 \\
9.7 \\
55.6\end{array}$ \\
\hline \multirow[t]{2}{*}{$\begin{array}{l}10 \\
10 \\
10\end{array}$} & $\begin{array}{l}10 \\
11 \\
11\end{array}$ & $\begin{array}{l}L A-6 \\
L A-3 \\
L A-2\end{array}$ & $\begin{array}{l}5,687 \\
5,575 \\
5,592\end{array}$ & $\begin{array}{l}5,761.9 \\
5,719.7 \\
5,719.7\end{array}$ & $\begin{array}{r}74.9 \\
144.7 \\
127.7\end{array}$ \\
\hline & & Steady state, & model 1 & er 4 & \\
\hline $\begin{array}{r}8 \\
9 \\
11 \\
11 \\
11\end{array}$ & $\begin{array}{r}8 \\
9 \\
6 \\
9 \\
10\end{array}$ & $\begin{array}{l}G-3 \\
G-1 \\
P M-3 \\
L A-4 \\
L A-5\end{array}$ & $\begin{array}{l}5,858 \\
5,778 \\
5,897 \\
5,697 \\
5,709\end{array}$ & $\begin{array}{l}5,839.4 \\
5,806.9 \\
5,893.4 \\
5,794.8 \\
5,761.5\end{array}$ & $\begin{array}{r}-18.6 \\
28.9 \\
-3.6 \\
97.8 \\
52.5\end{array}$ \\
\hline \multirow[t]{2}{*}{$\begin{array}{l}12 \\
13\end{array}$} & $\begin{array}{l}7 \\
5\end{array}$ & $\begin{array}{l}\mathrm{PM}-1 \\
\mathrm{PM}-2\end{array}$ & $\begin{array}{l}5,774 . \\
5,889 .\end{array}$ & $\begin{array}{l}5,873.9 \\
5,905.3\end{array}$ & $\begin{array}{l}99.9 \\
16.3\end{array}$ \\
\hline & & Transient, 1977 & , model & yer 1 & \\
\hline $\begin{array}{l}2 \\
2 \\
2 \\
3 \\
3\end{array}$ & $\begin{array}{l}20 \\
21 \\
24 \\
17 \\
19\end{array}$ & $\begin{array}{l}20.09 .05 .2443 \\
20.09 .04 .2234 \\
20.09 .01 .2223 \\
20.08 .12 .23412 \\
20.09 .06 .4422\end{array}$ & $\begin{array}{l}5,794.33 \\
5,828.06 \\
6,127.86 \\
5,671 . \\
5,745.21\end{array}$ & $\begin{array}{l}5,851 \cdot 8 \\
5,920.9 \\
6,185.4 \\
5,681.6 \\
5,808.4\end{array}$ & $\begin{array}{l}57.5 \\
92.8 \\
57.5 \\
10.6 \\
63.2\end{array}$ \\
\hline
\end{tabular}


Table 13.--Difference between measured and model-derived hydraulic heads, in feet--Continued

\begin{tabular}{|c|c|c|c|c|c|}
\hline \multicolumn{2}{|c|}{ Model } & \multirow{2}{*}{$\begin{array}{c}\text { Local well name } \\
\text { or number }\end{array}$} & \multicolumn{2}{|c|}{ Hydraulic head } & \multirow{2}{*}{$\begin{array}{c}\text { Difference } \\
\text { (model } \\
\text { derived } \\
\text { minus } \\
\text { measured) }\end{array}$} \\
\hline Row & Column & & Measured & $\begin{array}{l}\text { Model } \\
\text { derived }\end{array}$ & \\
\hline $\begin{array}{l}3 \\
3 \\
3 \\
3 \\
4\end{array}$ & $\begin{array}{l}19 \\
20 \\
24 \\
24 \\
18\end{array}$ & $\begin{array}{l}20.09 .05 .3224 \\
20.09 .09 .1124 \\
20.10 .07 .1111 \\
20.09 .01 .4444 \\
20.09 .18 .11114\end{array}$ & $\begin{array}{l}5,752.89 \\
5,819.89 \\
6,119.55 \\
6,122.72 \\
5,671.00\end{array}$ & $\begin{array}{l}5,808.4 \\
5,869.7 \\
6,180.6 \\
6,180.6 \\
5,768.6\end{array}$ & $\begin{array}{l}55.5 \\
49.8 \\
61.1 \\
57.9 \\
97.6\end{array}$ \\
\hline $\begin{array}{l}5 \\
5 \\
7 \\
8 \\
9\end{array}$ & $\begin{array}{l}19 \\
19 \\
19 \\
18 \\
13\end{array}$ & $\begin{array}{l}20.09 .19 .22311 \\
20.09 .18 .4212 \\
20.09 .30 .4241 \\
19.09 .06 .2311 \\
19.08 .06 .4224\end{array}$ & $\begin{array}{l}5,773.92 \\
5,777.78 \\
5,769.00 \\
5,842.58 \\
5,514.48\end{array}$ & $\begin{array}{l}5,845.1 \\
5,845.1 \\
5,873.3 \\
5,821.4 \\
5,512.7\end{array}$ & $\begin{array}{r}71 \cdot 2 \\
67.3 \\
104.3 \\
-21.2 \\
-1.8\end{array}$ \\
\hline $\begin{array}{l}9 \\
9 \\
9 \\
9 \\
9\end{array}$ & $\begin{array}{l}14 \\
18 \\
18 \\
19 \\
19\end{array}$ & $\begin{array}{l}19.08 .08 .42121 \\
19.08 .12 .4323 \\
19.09 .06 .4133 \\
19.09 .05 .3232 \\
19.09 .08 .1224\end{array}$ & $\begin{array}{l}5,556.70 \\
5,739.90 \\
5,829.85 \\
5,855.15 \\
5,874.74\end{array}$ & $\begin{array}{l}5,587.7 \\
5,788.0 \\
5,788.0 \\
5,854.8 \\
5,854.8\end{array}$ & $\begin{array}{r}31.0 \\
48.1 \\
-41.8 \\
-0.4 \\
-19.9\end{array}$ \\
\hline $\begin{array}{r}9 \\
10 \\
10 \\
12 \\
13\end{array}$ & $\begin{array}{r}20 \\
5 \\
17 \\
20 \\
21\end{array}$ & $\begin{array}{l}19.09 .09 .1444 \\
\mathrm{TW}-2 \\
19.09 .07 .1414 \\
19.09 .21 .34343 \\
19.09 .28 .4241\end{array}$ & $\begin{array}{l}5,928.96 \\
5,872.56 \\
5,794.00 \\
6,011.53 \\
6,140.00\end{array}$ & $\begin{array}{l}5,925.5 \\
5,891.4 \\
5,815.8 \\
6,048.9 \\
6,192.1\end{array}$ & $\begin{array}{l}-3.5 \\
18.8 \\
21.8 \\
37.4 \\
52.1\end{array}$ \\
\hline $\begin{array}{l}14 \\
15 \\
16 \\
17 \\
18\end{array}$ & $\begin{array}{r}25 \\
4 \\
24 \\
24 \\
23\end{array}$ & $\begin{array}{l}18.10 .06 .24314 \\
\text { DT-9 } \\
18.10 .18 .13112 \\
18.09 .24 .2424 \\
18.09 .25 .13111\end{array}$ & $\begin{array}{l}6,819.01 \\
5,930.90 \\
6,724.04 \\
6,733.40 \\
6,642.01\end{array}$ & $\begin{array}{l}6,876.4 \\
5,928.9 \\
6,629.2 \\
6,674.0 \\
6,689.2\end{array}$ & $\begin{array}{r}57.4 \\
-2.0 \\
-94.8 \\
-59.4 \\
47.2\end{array}$ \\
\hline $\begin{array}{l}18 \\
19 \\
19 \\
20 \\
20\end{array}$ & $\begin{array}{l}23 \\
19 \\
23 \\
18 \\
22\end{array}$ & $\begin{array}{l}18.09 .24 .4341 \\
18.09 .31 .42424 \\
18.09 .35 .2214 \\
17.09 .06 .14432 \\
17.09 .02 .211\end{array}$ & $\begin{array}{l}6,679.71 \\
6,229.90 \\
6,710.38 \\
6,213.59 \\
6,692.00\end{array}$ & $\begin{array}{l}6,689.2 \\
6,267.0 \\
6,678.3 \\
6,218.9 \\
6,580.3\end{array}$ & $\begin{array}{r}9.5 \\
37.1 \\
-32.1 \\
5.3 \\
-111.7\end{array}$ \\
\hline $\begin{array}{l}25 \\
25 \\
25 \\
25 \\
26\end{array}$ & $\begin{array}{l}21 \\
21 \\
21 \\
24 \\
20\end{array}$ & $\begin{array}{l}17.09 .28 .441 \\
17.09 .27 .31344 \\
17.09 .28 .423 \mathrm{~B} \\
17.10 .31 .134 \\
17.09 .33 .43212\end{array}$ & $\begin{array}{l}6,696.08 \\
6,696.69 \\
6,707 . \\
7,088.28 \\
6,508.55\end{array}$ & $\begin{array}{l}6,596.4 \\
6,596.4 \\
6,596.4 \\
7,172.4 \\
6,477.0\end{array}$ & $\begin{array}{r}-99.7 \\
-100.3 \\
-110.6 \\
84.1 \\
-31.6\end{array}$ \\
\hline $\begin{array}{l}26 \\
26 \\
26 \\
26 \\
26\end{array}$ & $\begin{array}{l}20 \\
20 \\
21 \\
22 \\
22\end{array}$ & $\begin{array}{l}16.09 .04 .11222 \\
17.09 .32 .44321 \\
16.09 .03 .1213 \mathrm{~B} \\
16.09 .02 .121 \\
16.09 .02 .31212\end{array}$ & $\begin{array}{l}6,512.72 \\
6,520.26 \\
6,696.61 \\
6,645.14 \\
6,646.15\end{array}$ & $\begin{array}{l}6,477.0 \\
6,477.0 \\
6,576.5 \\
6,671.4 \\
6,671.4\end{array}$ & $\begin{array}{r}-35.7 \\
-43.3 \\
-120.1 \\
26.3 \\
25.2\end{array}$ \\
\hline $\begin{array}{l}26 \\
27 \\
27 \\
28 \\
29\end{array}$ & $\begin{array}{l}23 \\
17 \\
22 \\
14 \\
17\end{array}$ & $\begin{array}{l}16.09 .01 .31121 \\
16.08 .12 .13114 \\
16.09 .10 .42114 \\
16.08 .17 .2122 \\
16.08 .14 .444\end{array}$ & $\begin{array}{l}6,790.73 \\
6,173.63 \\
6,603 . \\
6,148.95 \\
6,151.63\end{array}$ & $\begin{array}{l}6,783.0 \\
6,238.6 \\
6,653.0 \\
6,168.6 \\
6,198.2\end{array}$ & $\begin{array}{l}-7.7 \\
65.0 \\
50.0 \\
19.6 \\
46.6\end{array}$ \\
\hline $\begin{array}{l}29 \\
30 \\
33\end{array}$ & $\begin{array}{l}18 \\
16 \\
23\end{array}$ & $\begin{array}{l}16.08 .13 .444 \\
16.08 .26 .32112 \\
15.09 .01 .3314\end{array}$ & $\begin{array}{l}6,137.13 \\
6,158 \cdot 38 \\
6,533 \cdot 78\end{array}$ & $\begin{array}{l}6,214.5 \\
6,169.1 \\
6,552.9\end{array}$ & $\begin{array}{l}77.4 \\
10.7 \\
19.1\end{array}$ \\
\hline
\end{tabular}


Table 13.--Difference between measured and model-derived hydraulic heads, in feet--Continued

\begin{tabular}{|c|c|c|c|c|c|}
\hline \multicolumn{2}{|c|}{ Model } & \multirow[b]{2}{*}{$\begin{array}{c}\text { Local well name } \\
\text { or number }\end{array}$} & \multicolumn{2}{|c|}{ Hydraulic head } & \multirow{2}{*}{$\begin{array}{r}\text { Differ } \\
\text { (mod } \\
\text { deriv } \\
\text { minu } \\
\text { measur }\end{array}$} \\
\hline ROW & Column & & Measured & $\begin{array}{l}\text { Model } \\
\text { derived }\end{array}$ & \\
\hline & & Transient, 19 & model & layer 1 & \\
\hline $\begin{array}{l}2 \\
2 \\
3 \\
3 \\
3\end{array}$ & $\begin{array}{l}2.1 \\
23 \\
17 \\
18 \\
19\end{array}$ & $\begin{array}{l}20.09 .04 .2234 \\
20.09 .02 .2122 \\
20.08 .12 .23412 \\
20.09 .07 .1414 \\
20.09 .06 .4422\end{array}$ & $\begin{array}{l}5,826.38 \\
5,990 . \\
5,667 . \\
5,718.06 \\
5,747.30\end{array}$ & $\begin{array}{l}5,920.9 \\
6,075.8 \\
5,681.2 \\
5,747.7 \\
5,808.2\end{array}$ & $\begin{array}{l}94.5 \\
85.8 \\
14.2 \\
29.6 \\
60.9\end{array}$ \\
\hline $\begin{array}{l}3 \\
3 \\
4 \\
5 \\
5\end{array}$ & $\begin{array}{l}19 \\
24 \\
18 \\
19 \\
24\end{array}$ & $\begin{array}{l}20.09 .05 .3224 \\
20.09 .01 .4444 \\
20.09 .18 .32221 \\
20.09 .18 .4243 \\
20.09 .24 .24343\end{array}$ & $\begin{array}{l}5,756.55 \\
6,116.45 \\
5,710.79 \\
5,728.54 \\
6,370.76\end{array}$ & $\begin{array}{l}5,808.2 \\
6,180.5 \\
5,768.3 \\
5,844.8 \\
6,189.8\end{array}$ & $\begin{array}{r}51.6 \\
64.0 \\
57.5 \\
116.3 \\
-181.0\end{array}$ \\
\hline $\begin{array}{l}6 \\
8 \\
8 \\
8 \\
9\end{array}$ & $\begin{array}{l}19 \\
18 \\
19 \\
21 \\
14\end{array}$ & $\begin{array}{l}20.09 .19 .4244 \\
19.09 .06 .2333 \\
20.09 .32 .31233 \\
19.09 .04 .2212 \\
19.08 .08 .42121\end{array}$ & $\begin{array}{l}5,716.41 \\
5,844.26 \\
5,836.49 \\
5,981.12 \\
5,556.64\end{array}$ & $\begin{array}{l}5,860.8 \\
5,821.1 \\
5,877.3 \\
6,001.3 \\
5,587.6\end{array}$ & $\begin{array}{r}144.4 \\
-23.2 \\
40.8 \\
20.2 \\
31.0\end{array}$ \\
\hline $\begin{array}{l}9 \\
9 \\
9 \\
9 \\
9\end{array}$ & $\begin{array}{l}14 \\
15 \\
18 \\
19 \\
19\end{array}$ & $\begin{array}{l}19.08 .09 .2114 \\
19.08 .10 .12322 \\
19.09 .07 .1414 \\
19.09 .08 .2131 \\
19.09 .05 .4113\end{array}$ & $\begin{array}{l}5,566.46 \\
5,626.81 \\
5,792.25 \\
5,868.18 \\
5,868.22\end{array}$ & $\begin{array}{l}5,587.6 \\
5,615.0 \\
5,788.0 \\
5,854.8 \\
5,854.8\end{array}$ & $\begin{array}{r}21 \cdot 1 \\
-11.8 \\
-4.2 \\
-13.4 \\
-13 \cdot 4\end{array}$ \\
\hline $\begin{array}{r}9 \\
9 \\
9 \\
10 \\
10\end{array}$ & $\begin{array}{r}20 \\
21 \\
21 \\
3 \\
5\end{array}$ & $\begin{array}{l}19.09 .09 .1444 \\
19.09 .09 .2423 \\
19.09 .10 .4112 \\
\text { TW-4 } \\
\text { TW-2 }\end{array}$ & $\begin{array}{l}5,926.90 \\
5,974.03 \\
6,028.58 \\
6,069.94 \\
5,855.67\end{array}$ & $\begin{array}{l}5,925.5 \\
5,988.9 \\
5,988.9 \\
6,055.9 \\
5,876.9\end{array}$ & $\begin{array}{r}-1.4 \\
14.9 \\
-39.7 \\
-14.0 \\
21.2\end{array}$ \\
\hline $\begin{array}{l}10 \\
10 \\
10 \\
10 \\
11\end{array}$ & $\begin{array}{r}12 \\
16 \\
17 \\
21 \\
4\end{array}$ & $\begin{array}{l}19.08 .18 .2311 \\
19.08 .11 .3341 \\
19.08 .12 .3421 \\
19.09 .10 .3233 \\
\mathrm{TW}-8\end{array}$ & $\begin{array}{l}5,508.86 \\
5,641.36 \\
5,739.73 \\
5,992.54 \\
5,885.02\end{array}$ & $\begin{array}{l}5,500.7 \\
5,780.0 \\
5,815.0 \\
6,051.5 \\
5,928.3\end{array}$ & $\begin{array}{r}-8.2 \\
138.6 \\
75.3 \\
59.0 \\
43.3\end{array}$ \\
\hline $\begin{array}{l}11 \\
11 \\
12 \\
14 \\
15\end{array}$ & $\begin{array}{r}5 \\
8 \\
20 \\
4 \\
4\end{array}$ & $\begin{array}{l}\mathrm{TW}-3 \\
\mathrm{TW}-1 \\
19 \cdot 09 \cdot 21 \cdot 34343 \\
\mathrm{DT}-10 \\
\mathrm{DT}-9\end{array}$ & $\begin{array}{l}5,917.45 \\
5,832.09 \\
6,012.34 \\
5,922.26 \\
5,921.99\end{array}$ & $\begin{array}{l}5,871.1 \\
5,823.1 \\
6,048.9 \\
5,919.0 \\
5,921.3\end{array}$ & $\begin{array}{r}-46.4 \\
-9.0 \\
36.6 \\
-3.3 \\
-0.7\end{array}$ \\
\hline $\begin{array}{l}15 \\
15 \\
16 \\
16 \\
17\end{array}$ & $\begin{array}{l}22 \\
25 \\
24 \\
24 \\
24\end{array}$ & $\begin{array}{l}18.09 .10 .24211 \\
18.10 .08 .2133 \\
18.10 .07 .342 \\
18.10 .18 .13112 \\
18.09 .24 .2424\end{array}$ & $\begin{array}{l}6,359.22 \\
7,005.50 \\
6,680.39 \\
6,721.48 \\
6,726.44\end{array}$ & $\begin{array}{l}6,368.3 \\
6,798.5 \\
6,628.6 \\
6,628.6 \\
6,673.0\end{array}$ & $\begin{array}{r}9.1 \\
-207.0 \\
-51.8 \\
-92.9 \\
-53.4\end{array}$ \\
\hline $\begin{array}{l}18 \\
19 \\
24 \\
24 \\
25\end{array}$ & $\begin{array}{l}23 \\
23 \\
23 \\
24 \\
19\end{array}$ & $\begin{array}{l}18.09 .25 .13111 \\
18.09 .35 .2214 \\
17.09 .24 .343 \\
17.10 .30 .121 \\
17.09 .29 .43433\end{array}$ & $\begin{array}{l}6,637.34 \\
6,686.06 \\
6,953.25 \\
7,092.83 \\
6,555.41\end{array}$ & $\begin{array}{l}6,688.0 \\
6,676.4 \\
6,894.6 \\
7,150.8 \\
6,413.3\end{array}$ & $\begin{array}{r}50.7 \\
-9.7 \\
-58.6 \\
58.0 \\
-142.1\end{array}$ \\
\hline
\end{tabular}


Table 13.--Difference between measured and model-derived hydraulic heads, in feet--Concluded

\begin{tabular}{|c|c|c|c|c|c|}
\hline \multicolumn{2}{|c|}{ Model } & \multirow{2}{*}{$\begin{array}{c}\text { Local well name } \\
\text { or number }\end{array}$} & \multicolumn{2}{|c|}{ Hydraulic head } & \multirow{2}{*}{$\begin{array}{c}\text { Difference } \\
\text { (model } \\
\text { derived } \\
\text { minus } \\
\text { measured) }\end{array}$} \\
\hline Row & Column & & Measured & derived & \\
\hline $\begin{array}{l}25 \\
25 \\
25 \\
25 \\
25\end{array}$ & $\begin{array}{l}19 \\
20 \\
20 \\
21 \\
22\end{array}$ & $\begin{array}{l}17.09 .32 .312442 \\
17.09 .33 .32142 \\
17.09 .33 .2112 \\
17.09 .28 .423 \mathrm{~B} \\
17.09 .27 .441\end{array}$ & $\begin{array}{l}6,566.08 \\
6,503.93 \\
6,505.84 \\
6,703 . \\
6,618.26\end{array}$ & $\begin{array}{l}6,413.3 \\
6,494.8 \\
6,494.8 \\
6,567.9 \\
6,667.7\end{array}$ & $\begin{array}{r}-152.8 \\
-9.1 \\
-11.0 \\
-135.1 \\
49.4\end{array}$ \\
\hline $\begin{array}{l}25 \\
26 \\
26 \\
26 \\
26\end{array}$ & $\begin{array}{l}24 \\
18 \\
21 \\
23 \\
24\end{array}$ & $\begin{array}{l}17.10 .31 .134 \\
17.09 .31 .324 \\
16.09 .03 .1213 \mathrm{~A} \\
17.09 .36 .4332 \\
16.09 .01 .2413\end{array}$ & $\begin{array}{l}7,085.26 \\
6,158.18 \\
6,679.10 \\
6,999.95 \\
6,945.43\end{array}$ & $\begin{array}{l}7,167 \cdot 7 \\
6,240.2 \\
6,561 \cdot 3 \\
6,773.2 \\
6,932.5\end{array}$ & $\begin{array}{r}82.4 \\
82.0 \\
-117.8 \\
-226.8 \\
-12.9\end{array}$ \\
\hline $\begin{array}{l}27 \\
27 \\
28 \\
31 \\
32\end{array}$ & $\begin{array}{l}20 \\
22 \\
13 \\
17 \\
14\end{array}$ & $\begin{array}{l}16.09 .08 .22212 \\
16.09 .10 .42114 \\
16.08 .17 .2122 \\
16.08 .26 .4443 \\
16.08 .33 .4343\end{array}$ & $\begin{array}{l}6,581 \cdot 82 \\
6,594 \cdot \\
6,151 \cdot 33 \\
6,237 \cdot 56 \\
6,113 \cdot 53\end{array}$ & $\begin{array}{l}6,444.3 \\
6,647.8 \\
6,231.8 \\
6,182.6 \\
6,095.6\end{array}$ & $\begin{array}{r}-137.5 \\
53.8 \\
80.5 \\
-55.0 \\
-17.9\end{array}$ \\
\hline
\end{tabular}

Averages for the above groups of differences, in feet

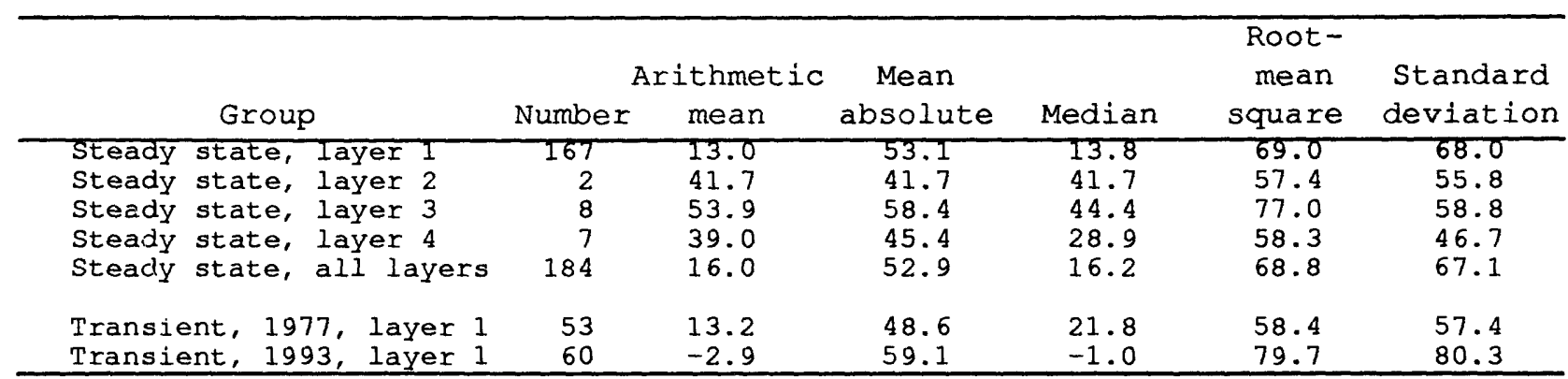

